Industrialização do ensino e política de educação a distância

ANTONIO ROBERTO FAUSTINO DA COSTA
울EESBNIO \& 풓APREEDIZLAEM

VOL. 4

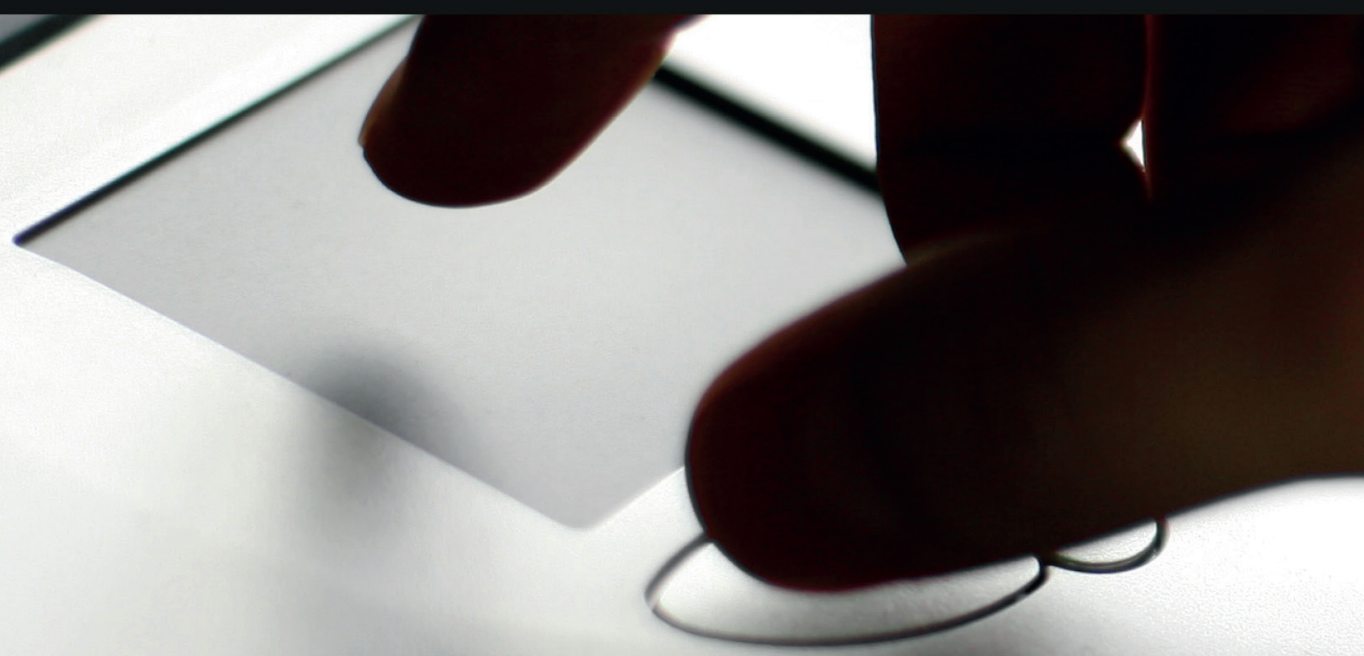



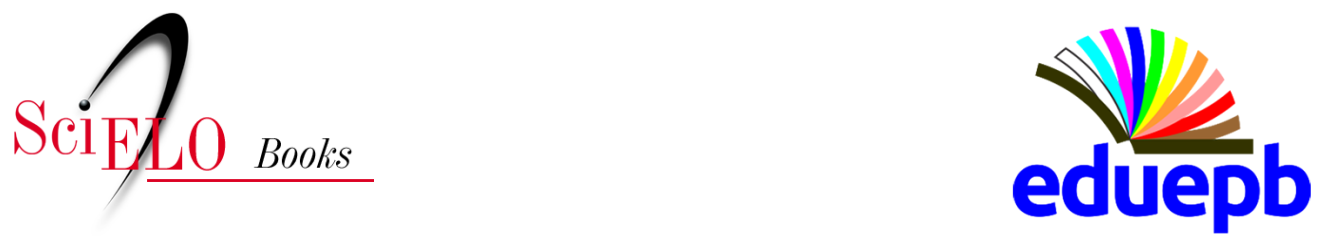

\title{
Industrialização do ensino e política de educação a distância
}

\author{
Antonio Roberto Faustino da Costa
}

\section{SciELO Books / SciELO Livros / SciELO Libros}

COSTA, A. R. F. Industrialização do ensino e política de educação a distância [online]. Campina Grande: EDUEPB, 2019, 362 p. Ensino e aprendizagem collection, vol. 4. ISBN: 978-85-7879-350-0.

https://doi.org/10.7476/9788578793500.

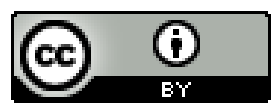

All the contents of this work, except where otherwise noted, is licensed under a Creative Commons Attribution 4.0 International license.

Todo o conteúdo deste trabalho, exceto quando houver ressalva, é publicado sob a licença Creative Commons Atribição 4.0.

Todo el contenido de esta obra, excepto donde se indique lo contrario, está bajo licencia de la licencia Creative Commons Reconocimento 4.0. 


\title{
Universidade Estadual da Paraíba \\ (1) Prof. Antonio Guedes Rangel Junior | Reitor \\ UEPB Prof. Flávio Romero Guimarães | Vice-Reitor \\ eduepb \\ Editora da Universidade Estadual da Paraíba
}

\author{
Luciano Nascimento Silva | Diretor \\ Antonio Roberto Faustino da Costa | Editor Assistente \\ Cidoval Morais de Sousa | Editor Assistente
}

\section{Conselho Editorial}

Luciano Nascimento Silva (UEPB) | José Luciano Albino Barbosa (UEPB)

Antonio Roberto Faustino da Costa (UEPB) | Antônio Guedes Rangel Junior (UEPB)

Cidoval Morais de Sousa (UEPB) | Flávio Romero Guimarães (UEPB)

\section{Conselho Científico}

Afrânio Silva Jardim (UERJ) Jonas Eduardo Gonzalez Lemos (IFRN)

Anne Augusta Alencar Leite (UFPB) Jorge Eduardo Douglas Price (UNCOMAHUE/ARG)

Carlos Wagner Dias Ferreira (UFRN) Flávio Romero Guimarães (UEPB)

Celso Fernandes Campilongo (USP/ PUC-SP) Juliana Magalhães Neuewander (UFRI)

Diego Duquelsky (UBA) Maria Creusa de Araújo Borges (UFPB)

Dimitre Braga Soares de Carvalho (UFRN) Pierre Souto Maior Coutinho Amorim (ASCES)

Eduardo Ramalho Rabenhorst (UFPB) Raffaele de Giorgi (UNISALENTO/IT)

Germano Ramalho (UEPB) Rodrigo Costa Ferreira (UEPB)

Glauber Salomão Leite (UEPB) Rosmar Antonni Rodrigues Cavalcanti de Alencar (UFAL)

Gonçalo Nicolau Cerqueira Sopas de Mello Bandeira (IPCA/PT) Vincenzo Carbone (UNINT/IT)

Gustavo Barbosa Mesquita Batista (UFPB) Vincenzo Milittelo (UNIPA/IT)

\section{Expediente EDUEPB}

Erick Ferreira Cabral | Design Gráfico e Editoração

Jefferson Ricardo Lima Araujo Nunes | Design Gráfico e Editoração

Leonardo Ramos Araujo | Design Gráfico e Editoração

Elizete Amaral de Medeiros | Revisão Linguística

Antonio de Brito Freire | Revisão Linguística

Danielle Correia Gomes | Divulgação

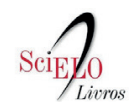

Editora indexada no SciELO desde 2012

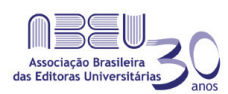

Editora filiada a ABEU

EDITORA DA UNIVERSIDADE ESTADUAL DA PARAÍBA

Rua Baraúnas, 351 - Bairro Universitário - Campina Grande-PB - CEP 58429-500 Fone/Fax: (83) 3315-3381 - http://eduepb.uepb.edu.br - email: eduepb@uepb.edu.br 
ANTONIO ROBERTO FAUSTINO DA COSTA

\section{INDUSTRIALIZAÇÃO DO ENSINO E POLÍTICA DE EDUCAÇÃO A DISTÂNCIA}

Coleção Ensino \& Aprendizagem

VOLUME 4

\section{eduepb}

Campina Grande 2019 


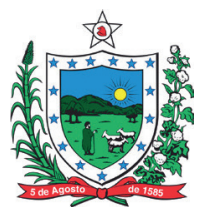

Estado da Paraíba

João Azevêdo Lins Filho | Governador
Ana Lígia Costa Feliciano | Vice-governadora
Nonato Bandeira | Secretário da Comunicação Institucional
Aléssio Trindade de Barros | Secretário da Educação e da Ciência e Tecnologia
Damião Ramos Cavalcanti | Secretário da Cultura

\title{
EPC - Empresa Paraibana de Comunicação
}

\author{
Naná Garcez | Diretora Presidente \\ William Campos| Diretora de Mídia Impressa \\ Alexandre Macedo | Gerente da Editora A União \\ Maria Eduarda Santos | Diretora de Rádio e TV
}

\section{AƯNIÃO}

BR 101 - KM 03 - Distrito Industrial - João Pessoa-PB - CEP: 58.082-010

Depósito legal na Biblioteca Nacional, conforme decreto $\mathrm{n}^{\circ} 1.825$, de 20 de dezembro de 1907 .

C837i Costa, Antonio Roberto Faustino da.

Industrialização do ensino e política de educação a distância [Livro

eletrônico]./Antonio Roberto Faustino da Costa. -Campina Grande: EDUEPB,

2019. (Coleção Ensino \& Aprendizagem; 4)

$2650 \mathrm{~Kb} .-362 \mathrm{p}$.

ISBN EDUEPB (papel): 978-85-7879-349-4

ISBN EDUEPB (e-book): 978-85-7879-350-0

ISBN EDITORA IFPB: 978-85-63406-85-9

ISBN EDITORA LIVRARIA DA FÍSICA: 978-85-7861-451-5

1. Ensino a distância. 2.Política de Educação a Distância (EaD) - Brasil. 3. Sistema de ensino

- Industrialização. I. Título.

Ficha catalográfica elaborada por Heliane Maria Idalino Silva-CRB-15³68

EDITORA DA UNIVERSIDADE ESTADUAL DA PARAÍBA

Rua Baraúnas, 351 - Bodocongó - Bairro Universitário

Campina Grande-PB - CEP 58429-500

Fone/Fax: (83) 3315-3381 - http://eduepb.uepb.edu.br

e-mail: eduepb@uepb.edu.br 


\section{Coleção Ensino \& Aprendizagem}

\section{Editores}

Fábio Marques de Souza

Simone Dália de Gusmão Aranha

\section{Conselho Científico}

Afrânio Mendes Catani (USP)

Alexsandro da Silva (UFPE)

Carla Luciane Blum Vestena (UNICENTRO)

Cesar Aparecido Nunes (UNICAMP)

Eduardo Gomes Onofre (UEPB)

Iraíde Marques de Freitas Barreiro (UNESP)

José Francisco de Melo Neto (UFPB)

Laura Janaina Dias Amato (UNILA)

Lucinalva Andrade Ataide de Almeida (UFPE)

Luiz Francisco Dias (UFMG)

Maria Helena Vieira Abrahão (UNESP)

María Isabel Pozzo (IRICE-Conicet- UNR, Argentina)

Marta Lúcia Cabrera Kfouri Kaneoya (UNESP)

Mona Mohamad Hawi (USP)

Rosa Ana Martín Vegas (USAL, Espanha)

Selma de Cássia Martinelli (UNICAMP)

Sinara de Oliveira Branco (UFCG) 


\section{Apresentação da Coleção}

A Coleção Ensino \& Aprendizagem visa à publicação e à divulgação de pesquisas desenvolvidas no âmbito do Programa de Pós-Graduação em Formação de Professores da Universidade Estadual da Paraíba - PPGFP/UEPB, assim como investigações de outros programas de pós-graduação do Brasil e do mundo. Os eixos norteadores estão ancorados em duas linhas de pesquisa, a saber: "Linguagens, Culturas e Formação Docente" e "Ciências, Tecnologias e Formação Docente", que subsidiaram as discussões, o desenvolvimento e os resultados das pesquisas realizadas.

Nesta Coleção, várias perspectivas de estudos direcionados a ações pedagógicas entram em cena. A partir dessa postura dialética, o PPGFP vislumbra promover reflexões teóricas e práticas a professores da Educação Básica e do Ensino Superior, que estejam em atividade e em formação inicial e continuada, buscando aperfeiçoar a sua prática docente, por meio de discussões acerca do complexo processo de ensino-aprendizagem. Busca, então, estimular professores, pesquisadores e demais profissionais envolvidos com a Educação e áreas afins, a fomentar um diálogo com a docência e suas práticas interculturais com vistas à produção do conhecimento científico. 


\section{SUMÁRIO}

\section{FUNDAMENTOS TEÓRICOS}

CONCEPÇÕES E ABORDAGENS SOBRE A EAD, 39

Da "Teoria do Estudo Independente" à "Teoria da Reintegração dos Atos Pedagógicos", 41

“Teoria da Industrialização do Ensino”, 54

A indústria do ensino e o Estado Industrial, 54

As origens do "paradigma" industrial, 63

Características industriais da EAD, 69

A EAD ENTRE O MODELO DE SOCIEDADE INDUSTRIAL E PÓS-INDUSTRIAL , 79

Mudanças estruturais na EAD, 87 
ESCAVANDO O TERRITÓRIO DA ANÁLISE DE DISCURSO

MAPA EPISTEMOLÓGICO DA AD, 106

OBJETO TEÓRICO E OBJETO EMPÍRICO:

uma questão de método, 115

A construção do corpus discursivo, 120

Universo e condições de produção da pesquisa, 127

Procedimentos de análise, 139

Dispositivo analítico, 146

\section{A EAD COMO PRÁTICA \\ POLÍTICO-SOCIAL E DISCURSIVA}

CONDIÇÕES DE PRODUÇÃO DO DISCURSO

EM TORNO DA EAD, 160

EM BUSCA DA FORMAÇÃO DO DISCURSO DA INDUSTRIALIZAÇÃO DO ENSINO NO BRASIL, 177

“Marco histórico" da EAD, 179

A situação de enunciação em torno da UAB, 180

Vozes e silêncios que calam e falam sobre a UAB, 183

UAB como estratégia dialógica, 187

Um discurso predominantemente autoritário, 192

As regularidades discursivas da UAB, 197

$U A B$ como acontecimento discursivo, 202 
Fragmentos da industrialização do ensino na UAB, 217

A racionalização do Sistema, 218

Divisão de trabalho e especialização burocráticoprofissional, 223

Mecanização e virtualidade da educação, 233

Do trabalho preparatório à centralização

administrativa, 239

Produção de massa como forma de democratização do ensino, 252

Continuidades e regularidades do discurso industrial, 260

A ordem e o sujeito do discurso oficial, 301 



\section{PREFÁCIO}

Mirian de Albuquerque Aquino ${ }^{1}$

O livro de Antonio Roberto Faustino da Costa é um desdobramento de sua tese de doutorado, intitulada "O discurso da industrialização do ensino na política nacional de educação a distância" e defendida no Programa de Pós-Graduação em Educação da Universidade Federal da Paraíba sob minha orientação. Coloca-se como um trabalho sério e rigoroso ao aceitar o desafio de afirmar que "o discurso da industrialização do ensino governa a prática discursiva que norteia a política nacional de educação a distância". Ao longo do texto, vemos uma série de elementos discursivos agregados à premissa maior segundo a qual "o Estado brasileiro exerce o papel de institucionalizar o processo de industrialização do ensino no país, criando as bases discursivas e não discursivas para

1 Professora aposentada do Programa de Pós-Graduação em Ciência da Informação e do Programa de Pós-Graduação em Educação da Universidade Federal da Paraíba, ex-orientadora de doutorado do autor. 
a expansão crescente da educação a distância (EAD) em nível nacional".

Os argumentos servem para reforçar a assertiva de que essa política, consolidada numa variedade de projetos, planos e programas, causou impacto no processo ensino-aprendizagem e ganhou "elevada importância junto à produção acadêmico-científica nacional", reforçando cada vez mais as concepções que defendem o uso das tecnologias da informação e comunicação na educação, sem considerar as ideologias que estão na base dessa política e "os discursos que orientam a incorporação em larga escala da EAD na rede pública de ensino".

$\mathrm{O}$ autor recorre a três ideologias que deram origem a diferentes teorias, concepções, abordagens e modelos de educação a distância, destacando a "teoria da interdependência e autonomia", a "teoria da comunicação e interação" e a "teoria da industrialização do ensino". A partir desta última, faz um exame da política nacional de EAD, para mostrar que a "abordagem parte da premissa de que, enquanto a educação face a face compreende formas pré-industriais, a educação a distância pressupõe essencialmente condições industriais de ensino", as quais teriam "como base o princípio da racionalização" que afeta o espírito, a letra e a política do processo de ensino-aprendizagem.

São argumentos que colocam em questão o atual discurso que orienta a política de EAD no Estado brasileiro. Partem eles, principalmente, das idéias do pensador alemão Otto Peters que identifica essa modalidade de educação com outras formas industriais de produção de bens, guardando semelhanças com alguns princípios inerentes ao que se tornou conhecido como Sociedade Industrial, destacando-se a racionalização, a divisão do trabalho, a 
produção em série, a atribuição de tarefas a especialistas, a estandardização, a planificação e a automação.

Antonio Roberto Faustino da Costa defende que o discurso da política nacional de EAD está enredado numa formação discursiva dominante que nada mais é do que os processos de industrialização de ensino em seu formato atualizado e revestido por novos teores. Defende que elementos da formação discursiva figuram no entremeio do discurso da EAD, "através dos fenômenos de continuidade, retorno e repetição". Essa incursão pelas linhas foucaultianas acende holofotes para a refletividade quando admite, claramente, que os vestígios de uma determinada formação social preexistente atestam a impossibilidade da existência de sociedades ou modelos puros. Elementos das formações discursivas pré-industriais, portanto, podem assombrar o que se considera como o novo.

Os sinais e as marcas de outras formações presentes no discurso da política nacional de EAD permitem adentrar o território da Análise de Discurso (AD) para escavar o terreno, retirar o que está oculto no subsolo, trazer à tona o que está escondido, rachar as palavras para "desvelar a essência dos processos discursivos". Deixam claro que o discurso que norteia a EAD não é transparente e, por essa razão, é preciso se transformar em um arqueólogo para encontrar não vestígios materiais sobre o comportamento e os padrões culturais de sociedades extintas, mas retirar as camadas densas para revelar o não-dito que permeia o discurso da política educativa.

Como analista desse discurso, o autor dialoga com um volume significativo de dados que se mostra numa linguagem, cheia de asperezas, alertando-nos que vai adentrar "as fundações de um território pantanoso", cheio de "atalhos, vestígios e inflexões", "lugares mutifacetados". 
Ele desloca o texto de uma linguagem dura, sem emoção, e adere sabiamente ao que diz Eni Orlandi: "existe uma estreita relação entre o geômetra e o poeta". Não deseja, entretanto, debruçar-se sobre a horizontalidade dos dados, porque os caminhos discursivos lhe permitem compreender que o importante é a verticalidade, o aprofundamento do fenômeno. Segue escavando o território, sem perder de vista que a AD é um método de compreensão de uma multiplicidade de objetos que não trabalha a linguagem como um dado, mas sua permanente relação com a sociedade e o sujeito em interação com ela.

A entrada no arquivo - onde estão armazenadas "as palavras e as coisas ditas" - ou seja, o lugar onde estão disponibilizados centenas de documentos, que fazem parte da memória coletiva, exigiu-lhe a identificação das condições de produção do discurso da EAD. Isto é, tomar como objeto empírico dez textos, cuja produção, difusão e circulação se dão numa conjuntura marcada pela expansão das tecnologias da informação e comunicação, da educação a distância e da mercantilização da educação em nível mundial, resultando na demanda crescente de ampliação e oferta de ensino superior a distância e semipresencial, com ênfase no atual governo.

A análise chama a atenção para o texto $n^{\circ} 10$ que traz um estudo acerca do ensino por correspondência no mundo, já em uso nas universidades norte-americanas, inferindo que tal documento "parece inaugurar uma espécie de discurso fundador que, a partir de então, passaria a nortear a política brasileira de educação a distância[...]. Aproximidando-se à ideia de que um discurso remete a outros discursos, o analista junta-se a Mónica Graciela ZOPPY-FONTANA (Cidadãos modernos: discurso e representação política. Campinas-SP: Ed. Unicamp, 1997. 
p. 171-172) para admitir que o discurso analisado não age solitariamente, mas concorre com outros discursos no mesmo intuito de "ocupar um lugar inaugural, ou mesmo, fundacional"; ao mesmo tempo que se mostra fundador, deixa transparecer "uma ilusão de corte ou ruptura com os processos de sentido sedimentados como memória discursiva".

Qual é a sua preocupação como interlocutor desses textos? Preocupa-se com as estratégias discursivas engendradas pelos articuladores da política de EAD, em sintonia com parceiros que se juntam a eles e os destinatários (alunos, professores, gestores, pesquisadores, especialistas, dentre outros), já que os textos são elaborados de acordo com a imagem que seus produtores têm dos receptores ou consumidores. Ele destaca que os produtores "assumem a posição de um sujeito competente que não se contenta apenas em se colocar no discurso, mas faz questão de acentuar sua competência como sujeito falante". Nessa análise capta o jogo discursivo que prioriza o eu e apaga a presença do outro, mantendo-o em silêncio numa linguagem didática que faz uso de uma tipologia discursiva que tende à normatização, à regra e aos preceitos. Caracterizando-se como um discurso eminentemente autoritário, emanado "dos lugares sociais e das posições privilegiadas que ocupam, pouca contribuição restará a ser dispensada por parte do outro".

A identificação dos fragmentos da industrialização do ensino na EAD serve para examinar as condições de produção do discurso, a posição dos locutores e os destinatários do discurso. De posse dessa estratégia, o analista vai retirando, escavando as camadas mais finas do terreno para revelar as lacunas, os apagamentos, os silenciamentos e as falhas que permeiam tal discurso. Afirmações tais 
como: "faltou aos locutores do T1 (melhor dizendo, estava fora de suas competências e propósitos) dizerem aquilo que ficou opaco: o discurso em torno da $\mathrm{UAB}$, na realidade, parte e converge na direção de reiterar o discurso da industrialização do ensino".

$\mathrm{Na}$ posição de analista do discurso, ele diz que pretende "desvendar aquilo que o discurso em torno da política de EAD teima em esconder, relega ao esquecimento, ou mesmo, faz questão de passar despercebido que é a recorrência, permanente e sistemática, às marcas ou propriedades discursivas [...]" que caracterizam o discurso da industrialização do ensino. Assumindo esse lugar, ele vai desvendando o jogo discursivo que permeia a política de EAD, por meio de recortes discursivos. O material empírico selecionado para análise permite ver a ênfase dispensada à voz do eu e o silenciamento do outro, como pode ser visto nas seqüências discursivas analisadas. É assim que o analista começa a desmascarar as nuanças do discurso, interpolações, interpelações, vieses, escamoteios, camuflagens, subterfúgios.

$\mathrm{O}$ discurso da política nacional de EAD analisado aponta uma tipologia discursiva (científico, narrativo etc.), mas em razão das condições de produção e o lugar de onde enuncia e os sujeitos autorizados para falar sobre tal discurso, ele prefere reconhece-lo como um discurso autoritário, assimétrico e estratégico, cuja reversibilidade mostra-se inexpressiva, com tendência a inibir qualquer possibilidade de interlocução. Trata-se de um discurso regulatório, normativo e impositivo, embora apresente contradições ou lacunas em suas regularidades e continuidades. Essa regularidade discursiva, segundo o analista, "não dá conta plenamente das condições de produção, difusão e circulação que engendra e transcende". 
Por outro lado, vemos que os fragmentos da industrialização do ensino da Universidade Aberta do Brasil (UAB), órgão norteador das ações referentes à EAD na atualidade, não escapam ao olhar aguçado do analista. Segundo ele, a ideologia que atravessa a filosofia da UAB é originária da "iniciativa privada, afetando as políticas públicas de natureza neoliberal, a partir das quais se articulam processos de desconcentração/descentralização", mas sem perder suas características concentradoras/ centralizadoras.

$\mathrm{Na}$ análise, não vemos passar ao largo a crítica ao processo de seleção e avaliação dos cursos da UAB, quando mostra que, mesmo se propondo a se organizar como um sistema aberto, contraditoriamente, no atendimento às demandas estatal-municipais carregam "os métodos de controle científicos" que visam a formalização e o planejamento prévio, características comuns aos cursos desta modalidade, oferecidos nas décadas de 1950 e 1960 e hoje recorrentes com o advento das tecnologias da informação e comunicação. Demonstrando assim que, apesar de se apresentarem com uma roupagem nova, guardam no entremeio os resquícios de práticas ideológicas já reconhecidas, celebradas como inovação, mas sutilmente marcadas pela eficiência, competência e produtividade.

$\mathrm{O}$ analista diz que o princípio da eficiência traz novamente à cena "o discurso do desenvolvimento nacional". Essa afirmação é líquida e certa, pois, aliados a outros, tal princípio é contemporaneamente dinamizado pela rapidez e sofisticação das tecnologias da informação e comunicação. Esse discurso é renovado, suas marcas são reiteradas, reproduzidas e resignificadas numa nova racionalidade globalizada e informacional que estabeleceu 
uma ordem discursiva legitimada por sujeitos do discurso institucional.

A quem essa nova ordem se dirige? A partir de uma seqüência do material empírico, o analista mostra que “à emergência de novas competências para o trabalho, provocadas pelos constantes avanços tecnológicos, novo modelo de desenvolvimento econômico brasileiro e desafios impostos pela sociedade global e do conhecimento". Além de reforçar o capital informacional, com seus fluxos de informação, conectividade e interatividade, essa nova racionalidade recria postos de trabalho, abre novas oportunidades, habilidades/competências, multiplicidade de profissões relacionadas à informação e novos "trabalhadores do conhecimento", configurando uma inclusão perversa, pois nem todos estão incluídos. A partir daí, uma nova divisão de trabalho se constitui na "cadeia produtiva", mais especificamente na década de 1990, com o princípio da inovação, bastante presente nas propostas de agências de fomento, como o CNPq.

O subtítulo "A ordem e o sujeito do discurso oficial" traz uma síntese significativa que instiga o leitor a refletir sobre as relações dos sujeitos com essa ordem e que a legitimam nas instituições de ensino, aceitando-a como tal. Diante do esquecimento ou ilusão de que o discurso não é transparente, mas opaco em todas as direções, o analista retoma os argumentos Michel Pêcheux para alertar que: "na condição de 'sempre-já' sujeito, assim como qualquer outro que assume uma posição condicionada institucionalmente, o sujeito que fala em nome do Estado - [toma] deste emprestada a palavra oficial, esquecendo-se das determinações que o colocaram no lugar que ocupa". Ele reafirma com Pêcheux e Fucs que tal esquecimento não "é um lapso de memória, mas aquilo que sempre se ignora, 
ainda que seja extremamente familiar às causas que determinam o discurso", concordando, discursivamente, que memória e esquecimento são, estranhamente, ligados "na enunciação do político".

Essa relação não permite uma interlocução transparente entre o eu e o outro, pois não é qualquer um que pode saber de qualquer coisa, ter acesso pleno ao que o outro diz. Há no discurso regiões do conhecimento que são intransitáveis, indecifráveis, que exigem credenciais para participar delas. São linguagens densas, entretecidas, de tal forma, por onde circulam as determinações, circulações, conhecidas pela Análise do Discurso como discursos-transversos e pré-construídos e derivados do sujeito universal, o qual não permite ser entendido por meio da consciência individual, já que esta não passa de "apenas um inquilino do edifício social dos signos ideológicos" (Mikhail BAKHTIN. Marxismo e filosofia da linguagem: problemas fundamentais do método sociológico na ciência da linguagem. 4. ed. São Paulo: Hucitec, 1988. p. 36) que atravessam o discurso oficial.

Outra questão importante do estudo é que nos faz entender que o funcionamento dos discursos, de qualquer natureza, precisa manter o controle sobre o modo como a língua, a história e a ideologia funcionam, sem perder a consciência coletiva desse processo no jogo de uma exterioridade, em que o sujeito é situado, sem jamais ser dono do dizer. $\mathrm{O}$ analista chama atenção, no entanto, para a compreensão de que o sujeito não é totalmente dependente como insinuou Althusser, nem o seu discurso se deixa aprisionar o tempo todo pelas determinações, mas "todo discurso, mesmo remetendo a outros discursos e intertextualidades, "carrega em si a potencialidade de desestruturação, reestruturação ou agitação, constituindo 
não apenas efeito, mas também um trabalho consciente ou inconsciente de deslocamento das filiações de identificação". E diz mais: "A capacidade de reação do sujeito ao discurso dominante é possível, sobretudo, através de uma ação dialética que lhe permita negociar e fazer novas interpretações", ou seja, exercer a sua capacidade de desestabilizar e "reorganizar as práticas discursivas".

O discurso não se dissocia de sua exterioridade. Esse vínculo vai sendo mostrado ao longo da análise, sob o argumento de que "o discurso em torno da política nacional de educação a distância, embora constituído e reconstituído por uma série de acontecimentos discursivos, dificilmente poderia se encontrar desencarnado, ou mesmo, desidentificado do aparato burocrático-institucional". O discurso oficial do Estado brasileiro, segundo o analista, mesmo sob o impacto dos "regimes mais ou menos democráti$\cos ^{\prime \prime}$, apresenta-se como um discurso autoritário. Desde a década de 1950, encontra-se assujeitado pois à formação discursiva referente à industrialização do ensino, com seus vestígios e fragmentos que se mantem "mediante o intradiscurso, que permitem àquela formação reger ou presidir o discurso enquanto estrutura que permanece ou mantém uma continuidade (memória discursiva) [...]" (idem). Entende também o analista que "o acontecimento discursivo apenas é capaz de modificar a estrutura até o ponto que a formação discursiva dominante precisa atualizar-se, exercendo uma governabilidade discursiva" em meio a outras formações.

O analista defende que o discurso político-pedagógico contemporâneo "estaria em função da dominação, manutenção e legitimação da EAD" em todo o mundo, supondo também que essa modalidade de ensino na atual economia informacional retoma os pressupostos althusserianos 
segundo os quais a escola das formações capitalistas avançadas nada mais é do que aparelho ideológico do Estado. Da mesma forma, entende que a EAD representa esse aparelho que assumiu a posição dominante na formação capitalista informacional contemporânea, invadindo praticamente todas as instituições universitárias, por meio de cursos de formação de professores, alunos, tutores e gestores a distância.

Ponto de vista esse que se assemelha ao que Michel FOUCAULT (Microfísica do poder. Rio de Janeiro: Graal, 2006) identificou como "formas de governo", não se preocupando apenas com as estruturas políticas mais amplas ou a administração estatal, mas, para além disso, como um governo que fiscaliza por meio de instrumentos avaliativos a forma mediante a qual a conduta dos indivíduos ou grupos pode ser dirigida. Governar, nesse sentido, é estruturar o campo possível das ações dos outros. Essas novas formas de governo, aparentemente, revelam uma mudança, abertura, mas nas suas relações exercem um poder disciplinar, mobilizado por meio de tecnologias normalizadoras do eu, tornando-se, muitas vezes, invisíveis, mas assegurando a "garra do poder" que se exerce sobre o outro.

Justamente é o poder disciplinar que suprime a crítica, a vontade de verdade, ao afiar suas armas para controlar o que não se deve dizer, pois é necessária a manutenção da "política do silêncio". É também essa face do discurso que sua função de analista quer mostrar aos leitores, alunos, professores, gestores e pesquisadores, pois ver nesse discurso o emprego de figuras de linguagem com a função de persuadir e seduzir, muito mais do que deixar às claras a "transparência do discurso". 
Em seu papel de analista de um discurso, ele afirma que, mesmo com as dificuldades enfrentadas para desentranhar os dispositivos e as estratégias onde se ancoram o discurso oficial, já que não é transparente, o "discurso das ideologias políticas, expressas mediante políticas educativas vinculadas a formas específicas e circunstanciais assumidas pelo Estado [...] continua o mesmo, pois a sua inscrição já está garantida no modo de produção capitalista, liberal, "de onde emanam as injunções econômicas que orientam, em grande parte, as políticas sociais".

Reforçando seu ponto de vista, ele remete-nos à proposição de Zygmunt BAUMAN (Vidas desperdiçadas. Rio de Janeiro: Zahar, 2005. p. 41), para quem tal condição não se refere apenas ao Estado Brasileiro ou ao mundo contemporâneo, mas é parte de uma modernidade líquida, onde "a condição de produção é compulsiva e viciosa", materializada nas propostas de formulação e execução de projetos, demarcando a política de EAD nas instituições de ensino na sociedade brasileira. $\mathrm{O}$ teor discursivo aí implícito pouco se distancia da "própria continuidade político-institucional" das políticas anteriores e com isso consegue manter a sua regularidade, circularidade e continuidade. Como diz Antonio Roberto Faustino da Costa,

imprimindo permanente e sistemática circularidade ao discurso, o acontecimento discursivo exerce papel fundamental à repercussão, legitimação e consolidação desses enunciados retores. Através de sua produção, difusão e circulação em larga escala cada vez mais abrangente, responde o acontecimento a uma intensa necessidade do discurso 
oficial em se inscrever sempre tanto em um lugar como em um tempo que vão muito além da superfície lingüística.

A epistemologia discursiva permite ver o discurso da política de EAD como "uma luta permanente", configurada por suas continuidades, descontinuidades e regularidades. Ao fazer essa análise, ele instiga-nos a compreender que tal discurso é "uma prática que põe em jogo a materialidade e a exterioridade do discurso", e aponta as contradições, incoerências, falhas e lacunas do discurso. Um discurso que, em sua movência ou errância, atravessa diferentes formações discursivas. Também traz elementos importantes para uma reflexão sobre o formato, o conteúdo, o material instrucional e os contextos específicos, que subsidiam a oferta de cursos não-presenciais nas universidades públicas, com o propósito de formação de professores leigos que atuam nas escolas públicas, bem como o atendimento de jovens e adultos que residem no interior do Estado, sem acesso à educação superior pública. Coloca-nos também a preocupação: “a análise da prática política, sem dúvida, é uma das formas importantes de compreender a prática social".

Por fim, gostaria de registrar que a oportunidade de ter acompanhado os estudos e o desenvolvimento da pesquisa de Antonio Roberto Faustino da Costa foi para mim uma inenarrável experiência de aprendizado, não só pelas diferentes formas de interlocuções que se deram desde seu ponto de partida até a finalização do trabalho. Sem arrogância, mas com humildade e sabedoria, soube dialogar com os autores, "sequer imaginados de carne e osso, mas sempre presentes", dotando-se de uma coerência 
discursiva e responsabilidade textual para divergir ou convergir, mas sempre atento em meio às semelhanças e diferenças.

$\mathrm{O}$ autor revela o perfil de um pesquisador que não mediu esforços para enfrentar a dureza de um volume excessivo de dados. Entre um interstício e outro, o analista-pesquisador encontrou o itinerário de sua pesquisa, abriu outros caminhos, outras possibilidades. Esquartejou os textos, fez a garimpagem e desentranhou um discurso que se ocultava nas entrelinhas.

Espero que a publicação deste livro possa contribuir para novas pesquisas. 


\section{INTRODUÇÃO²}

A tese deste estudo é que o discurso da industrialização do ensino governa a prática discursiva que norteia a política nacional de educação a distância. O argumento que fundamenta nossa tese considera que, desde meados do século $X X$, o Estado brasileiro exerce o papel de institucionalizar o processo de industrialização do ensino no país, criando as bases discursivas e não discursivas para a expansão crescente da educação a distância (EAD) em nível nacional.

2 Em que pese alterações incidentes sobre a política nacional de educação a distância na última década, decidiu-se manter aqui em grande parte o texto originalmente apresentado, em agosto de 2008, como tese de doutorado, junto ao Programa de Pós-Graduação em Educação (PPGE) da Universidade Federal da Paraíba (UFPB). O que implica considerar contribuições da Banca Examinadora sobre a versão final da referida tese, composta pelos professores Mirian de Albuquerque Aquino (orientadora), Arnon Alberto Mascarenhas de Andrade, Ivone Tavares de Lucena, Olga Maria Tavares da Silva e Maria da Salete Barboza de Farias. Além da supressão de alguns tópicos do texto original, decidiu-se também intitular o presente livro de "Industrialização do ensino e política de educação a distância", em substituição ao título original mais extenso, "O discurso da industrialização do ensino na Política Nacional de Educação a Distância". 
Como resultado, o Brasil passa a dispor de um dos maiores sistemas de EAD em todo o mundo, abrangendo desde o ensino fundamental até a educação corporativa.

Alicerçada no avanço das tecnologias de informação e comunicação (TICs), a EAD expande-se no país, sobretudo na última década, comprometida em ampliar a oferta de ensino, a qualificação profissional e a educação continuada. $\mathrm{O}$ "Anuário brasileiro estatístico de educação aberta e a distância" - ABRAEAD 2008 aponta que o total de matrículas em cursos a distância no ano passado superou os 2,5 milhões de estudantes, havendo estimativa de um aumento de $40 \%$ para 2010 (PORTAL, 2008). O ABRAEAD 2007 havia assinalado que os maiores investimentos em EAD provinham das empresas privadas e do treinamento de funcionários, observando-se em paralelo o incremento das políticas públicas (SUA EXCELÊNCIA, 2007, p.137).

$\mathrm{Na}$ realidade, instaura-se junto ao Estado brasileiro uma política nacional de educação a distância, baseada em uma série de programas e sistemas de EAD sem precedentes na história do país. Graças à exigência legal de todo professor do ensino básico ter um curso de graduação, a formação docente é a principal atividade dos projetos públicos em EAD, destacando-se os consórcios envolvendo instituições de educação superior, como o Veredas de Minas Gerais, o Cederj (Centro de Educação Superior a Distância do Estado do Rio de Janeiro) (AS INSTITUIÇÕES, 2007, p.39) e o Sistema Universidade Aberta do Brasil (UAB). Até 2010, a UAB prevê alcançar 140 mil alunos matriculados em cursos de graduação e pós-graduação a distância que serão ofertados em todo o país por 830 pólos de apoio presencial (BRASIL, 2008c).

A expansão da EAD no Brasil é consubstanciada pela emergência de um marco regulatório que vai induzir a 
expansão do sistema público de ensino na direção de responder a uma demanda de caráter nacional e universal. Com a inclusão e posterior regulamentação do artigo 80 da Lei de Diretrizes e Bases da Educação Nacional (LDB) de 1996, que trata do ensino a distância, a EAD recebe um forte impulso a sua institucionalização. Ao mesmo tempo, o Ministério da Educação (MEC) cria em torno da Secretaria de Educação a Distância (SEED) toda uma estrutura de governo voltada, especialmente, para atuar no campo do ensino a distância, consolidando assim uma legitimidade burocrático-institucional junto à EAD (A ALTERNATIVA, 2007, p.149).

O impacto da EAD no processo de ensino-aprendizagem, concomitantemente, ganha elevada importância junto à produção acadêmico-científica nacional, mediante estudos e pesquisas que passam a abordar a influência que as TICs exercem na sala de aula, na prática pedagógica e nas experiências de aprendizagem. Realizada a partir de 2004 e envolvendo diversas áreas, a "Pesquisa colaborativa sobre a produção do conhecimento em educação a distância no Brasil, de 1999 a 2006", que representa um amplo e atualizado mapeamento a respeito dessa produção, registra quase 2.200 trabalhos que abordam a temática da EAD, incluindo teses e dissertações. Confirmando a prevalência entre os estudos do interesse pela tecnologia educacional, suporte, serviços, gestão e logística, a edição da pesquisa publicada em 2007 assinala o refluxo dos estudos de natureza estratégica, filosófica e política (ANDRÉ et al, 2007, p.163) .

Além de negligenciar aspectos importantes, essa produção tem pouco contribuído para superarmos um posicionamento, muitas vezes, acrítico que não aprofunda as repercussões provocadas pelo processo de inovação e 
globalização por que passa a educação na sociedade contemporânea. Marca essa literatura, em particular, uma atenção tímida relativamente aos fundamentos macroestruturais da educação a distância, a destacar os discursos que orientam a incorporação em larga escala da EAD na rede pública de ensino.

A nossa preocupação com os rumos da EAD no país remonta os inícios dos anos 2000, quando coordenávamos e orientávamos projetos de pesquisa junto ao Departamento de Comunicação Social da Universidade Estadual da Paraíba (UEPB). As pesquisas então desenvolvidas culminaram na plaquete "(Des)Caminhos da educação a distância no Brasil do século XX" (não publicada) que tentava revisar, sumariamente, as continuidades e descontinuidades da política nacional de EAD, desde o cinema educativo até a TV Escola (COSTA, 2001). Consolidando nossas inquietações, em 2004, originava o presente estudo o seguinte problema: quais os fundamentos político-pedagógicos que orientam a política de educação a distância do Estado brasileiro?

Tomando como premissa a indignação permanente da pedagogia de Freire (2000), a problemática foi transformada em projeto de doutoramento, submetido e aprovado para ser desenvolvido junto ao Programa de Pós-Graduação em Educação (PPGE) da Universidade Federal da Paraíba (UFPB), sob orientação da Prof ${ }^{a}$ Dr $^{a}$ Mirian de Albuquerque Aquino. Além de se inscrever em um programa cuja tradição na área de concentração assume caráter ímpar no país, devotado às interrelações entre Educação Popular, Comunicação e Cultura, o projeto vinculava-se à linha de pesquisa Estudos Culturais e Tecnologias de Informação e Comunicação. Atualmente denominada Estudos Culturais da Educação, a linha 
mantém como um dos seus principais objetivos tratar dos fundamentos desses estudos e de suas interfaces nos processos culturais e comunicacionais.

Naquele momento, nossa preocupação se concentrava em caracterizar e cotejar os paradigmas teóricos que orientavam a política de EAD nos governos Fernando Henrique Cardoso e Luís Inácio Lula da Silva, até porque reportavam ambos ao período de maior expansão da educação a distância no país. Ao final do primeiro ano de doutoramento, foi possível elucidarmos, mais precisamente, o que concebíamos como paradigmas. Como resultado do estudo "Abordagens teóricas da educação a distância" (COSTA, 2005), constatamos através de revisão da literatura que - refletindo o próprio dilema da pedagogia e das ciências da educação - a EAD não dispunha de teorias endógenas e sua fundamentação inscrevia-se nos marcos das teorias da aprendizagem, gestadas em domínios científicos que fazem interface com a pedagogia. Por último, a literatura internacional nos permitiu vislumbrar a prevalência não propriamente de teorias, mas de três abordagens de cunho teórico-conceitual que tomavam a EAD como fenômeno - teoria da independência e autonomia, teoria da comunicação e interação e teoria da industrialização do ensino.

A partir de então, a noção de industrialização do ensino formulada pelo pensador alemão Otto Peters passou a ser adotada como arcabouço teórico do nosso projeto de tese. Além de se destacar entre as principais abordagens no campo da educação a distância (KEEGAN, 1991), a concepção apresenta-se como a mais abrangente para dar conta da complexidade do fenômeno da EAD no mundo contemporâneo. Empregada para caracterizar e diferenciar a educação a distância da educação presencial, 
a abordagem parte da premissa de que, enquanto a educação face a face compreende formas pré-industriais, a EAD pressupõe essencialmente condições industriais de ensino.

Tais condições têm como base o princípio da racionalização, caracterizada através da substituição do trabalho individual pela produção baseada na divisão de trabalho que conduz ao surgimento e expansão crescente de linhas de montagem e da produção de massa. Como conseqüência, o processo pedagógico em educação a distância é reestruturado por mecanização e automação, condições essenciais para as seguintes características emergirem: a concepção prévia dos cursos igualmente ao trabalho preparatório que acontece antes do processo de produção; a dependência da efetividade do processo pedagógico ao planejamento, organização, formalização, padronização, objetivação e adoção de métodos racionais e científicos; a mudança de função e especialização dos profissionais envolvidos; a concentração dos recursos e uma administração centralizada (PETERS, 1967).

Mesmo assim, o problema de apontar os fundamentos da política de EAD ainda não estaria plenamente elucidado, dado que a solução seria de outra ordem. O comportamento político aí em jogo seria atravessado por uma prática discursiva que, embora guardando relação com as determinações econômico-sociais, não coincidiria com estas nem muito menos com as teorias políticas vigentes (FOUCAULT, 2002, p.220). Tomando como base esse pressuposto, adotamos como referencial teórico-metodológico a Análise de Discurso de orientação francesa que, apoiada no materialismo histórico, na lingüística, na psicanálise e na teoria do discurso, permite-nos conceber a industrialização do ensino do ponto de vista discursivo, 
como configurando - além de uma abordagem teórica um sistema de enunciabilidade.

Levando em conta sua natureza, complexidade e, sobretudo, extrema relevância na agenda da sociedade contemporânea, consideramos que a industrialização do ensino comporta em si uma formação discursiva, direta e substancialmente, determinada pelas injunções da formação ideológica e social capitalista no campo da educação. O que lhe impõe, a priori, está intrinsecamente caracterizada e a serviço do modelo de produção industrial, muito mais ainda, em estágio crescente de globalização. Donde decorre sua luta permanente com outras formações discursivas - em destaque aquelas que privilegiam, por um lado, a independência e autonomia e, por outro, a comunicação e interação - para nortear os discursos relacionados aos sistemas e políticas de EAD em todo o mundo, incluindo o Brasil.

Assumindo a idéia da industrialização do ensino como formação discursiva, levantamos então as seguintes pressuposições:

a) O processo de reestruturação do modo de produção capitalista, com ênfase na globalização da economia e na centralidade da informação, da comunicação e do conhecimento, contribui para acentuar progressivamente as condições que caracterizam, desde o início, a estrutura industrial da EAD;

b) A política nacional de educação a distância configura-se como um dispositivo de institucionalização da industrialização do ensino no país, sobretudo, quando consideramos que a própria política educativa brasileira - mormente no estágio de hegemonia do neoliberalismo em nível global - impõe ao 
sistema de ensino como um todo um processo de racionalização e modernização sem precedentes;

c) Além de atrelada aos sistemas econômico, social, cultural e pedagógico, a política de EAD encontra-se articulada a uma prática discursiva que lhe induz a ser regida pelo sistema de formação discursiva que comporta a industrialização do ensino.

Nosso estudo, a partir dessa delimitação, passou a ter como objetivo geral analisar como a industrialização do ensino constitui-se em formação discursiva dominante do discurso em torno da política nacional de educação a distância. Isso não impediria que elementos da formação discursiva pré-industrial figurem no entremeio desse discurso, através de fenômenos de continuidade, retorno e repetição (FOUCAULT, 2002, p.197). Sua presença, contudo, assim como a de outras formações que poderiam estabelecer relações contraditórias importantes à constituição e reformulação do discurso em questão, parece não ser determinante.

Mais especificamente, dois objetivos se destinam a dar conta de como essa determinação se processa e funciona, na ordem do discurso e das práticas não-discursivas. $\mathrm{O}$ primeiro objetivo específico visa (a) evidenciar como o discurso oficial reveste-se de uma prática discursiva capaz de fazer predominar a industrialização do ensino entre as formações discursivas que se debatem em torno da política de EAD. Nossa intenção, a partir daí, é compreender como se organiza a materialidade e a exterioridade do discurso, identificando as suas regularidades e descontinuidades, condições de produção, posições dos sujeitos envolvidos e formações discursivas e ideológicas que mobiliza. 
O segundo objetivo específico, por sua vez, visa (b) elucidar como essa prática discursiva sofre os efeitos e é capaz de influenciar a prática social refletida na política de EAD. Partimos do pressuposto de que esta última, embora atrelada a uma ordem sócio-histórica de natureza macro-estrutural, não determina a priori o discurso oficial; mas que este, também, é condicionado pelos acontecimentos que a prática discursiva retoma, instaura, reformula e faz circular constantemente, tornando-se capaz de produzir efeitos sobre as decisões políticas. Nossa intenção, desta feita, é entender como se relacionam a estrutura e o acontecimento discursivo, no curso de uma política de Estado conduzida sob a égide da formação social onde predomina o modo de produção capitalista.

O nosso estudo está inscrito, dessa forma, no entremeio de um discurso cuja complexidade atravessa a política, a sociologia e a linguagem nos sistemas educativos, as necessidades e determinações político-sociais na criação de ideologias e na legitimação de interesses no campo educacional, formando um estado de processo discursivo apoiado na história. É inegável que temos consciência de que existe uma distância entre os objetivos declarados no discurso oficial e aqueles efetivamente perseguidos pelos sistemas educativos. Desvelar a essência dos processos discursivos e das próprias políticas educativas, muitas vezes difusas, representa uma preocupação ética e social de tamanha importância que torna premente aprofundarmos a análise da incorporação de novas linguagens e tecnologias na educação pública, sob um olhar essencialmente crítico (FREIRE, 2000).

Para tentarmos responder a essas inquietações, estruturamos o trabalho em quatro capítulos que traduzem mais detalhadamente os argumentos aqui apresentados. 
No Capítulo 2, definimos as origens, características e conceitos centrais à educação a distância como campo de conhecimento. Nosso argumento principal é que a industrialização do ensino constitui a abordagem que melhor dá conta do fenômeno da EAD sob uma perspectiva sociológica, fundamentando e contextualizando a tese aqui apresentada.

No Capítulo 3, problematizamos e delimitamos a Análise de Discurso faceao fenômeno em estudo, definindo a sua natureza de dispositivo analítico, a constituição do corpus discursivo e os procedimentos metodológicos aplicados à análise dos dados empíricos. $\mathrm{O}$ corpus que pesquisamos compreende, basicamente, um grupo de dez textos que representam os discursos oficiais, pronunciados nas últimas seis décadas, que dão suporte à política nacional de EAD. A despeito de tão largo período, a nossa preocupação não reside na tentativa de arrolar exaustivamente o conjunto dos documentos e publicações relacionados ao fenômeno, mas sobretudo vislumbrar a regularidade e a vinculação desse discurso a uma formação discursiva.

No Capítulo 4, apontamos como a política de EAD constitui, ao mesmo tempo, uma prática social e discursiva, visando compreender suas continuidades e descontinuidades. Percorrendo as suas condições de produção, situamos o corpus discursivo inicialmente nos marcos do Estado contemporâneo, objetivando estabelecer a relação entre educação, políticas públicas e discurso. Logo em seguida, examinamos mais detalhada e profundamente como a materialidade lingüística desse corpus transforma-se em discurso, ganha sentido e circularidade. Nossa ênfase recai sobre o discurso em torno da Universidade Aberta do Brasil, mais recente e representativo da atual política de EAD, porém estendemos a análise aos demais 
textos, no sentido de desvendarmos como a regularidade discursiva afeta outros contextos sócio-históricos também importantes à vida nacional.

Nas Considerações Finais, ao apresentarmos as principais conclusões deste estudo, reforçamos nossa tese convictos de contribuir para uma posição crítica face ao discurso da política nacional de educação a distância. Postura que não deixa de representar uma prática discursiva, investida de uma possibilidade concreta de prática social. 



\section{FUNDAMENTOS TEÓRICOS DA EDUCAÇÃO A DISTÂNCIA}

Neste estudo, tomamos o fenômeno da educação a distância sob uma perspectiva teórico-conceitual, concentrando sua análise no campo da pedagogia. A distinção entre educação e pedagogia formulada por Émile Durkheim parece bastante sugestiva do que nos interessa, particularmente, examinar. Diversamente da educação, a pedagogia "não consiste em ações, mas em teorias. Essas teorias são maneiras de conceber a educação, não são maneiras de praticá-la. Por vezes, distinguem-se das práticas em uso, a ponto de se oporem a elas, francamente." (DURKHEIM, 1973, p.57-58).

Partimos da pressuposição de que, em contraposição aos avanços teóricos da pedagogia relativamente à educação presencial, a EAD ainda não haveria desenvolvido abordagens capazes de ser consideradas teorias. Em lugar disso, têm sido adaptadas à EAD as abordagens tradicionais de ensino e de aprendizagem: o modelo de controle do comportamento de Skinner; o modelo de Rhothkopf para a instrução por escrito; o modelo organizador do desenvolvimento de Ausubel; o modelo de comunicação estrutural de Egan; o modelo de aprendizagem pela 
descoberta de Bruner; o modelo de facilitação de Karl Rogers; e o modelo geral de ensino de Gagnér.

A essas abordagens acrescenta-se a chamada teoria da conversação didática guiada de Borje Holmberg que representaria o único modelo voltado, especificamente, para a EAD. Representaria, também, o modelo acrescentado por Laaser e sua equipe (LAASER, 1997, p.26) ao quadro já apresentado por John Baath. Em seu livro "Correspondence education in the light of a number of contemporary teaching models", publicado em 1979, Baath analisa a aplicabilidade das teorias de Skinner, Rotkopt, Ausubel, Bruner, Rogers, Gagné e Egan à EAD (HOLMBERG, 1995), destacando que todos os modelos poderiam ser aplicados à EAD, alguns deles mais facilmente que outros (REKKEDAL, 1994).

Essa aplicação se daria mediante o esforço dos tutores de programas de EAD em individualizar a instrução do aluno com respeito aos padrões prévios (Skinner); facilitar as atividades (Rothkopf); apoiar as primeiras lições no conhecimento prévio e na estrutura cognitiva do estudante (Ausubel); ter idéia do grau de compreensão do aluno acerca dos conceitos básicos e princípios do curso (Bruner); enfim, estabelecer uma boa relação pessoal com o estudante (Rogers) (HOLMBERG, 1999). A teoria da distância transacional, uma das primeiras abordagens teóricas da EAD, lançada no início dos anos 1970, pretendia, aliás, fazer a fusão de duas tradições pedagógicas - $\mathrm{o}$ humanismo e o behaviorismo. A sua principal intenção foi romper com a hegemonia deste último, a indicar o título do estudo que deu origem à abordagem: "A autonomia do aluno: a segunda dimensão da aprendizagem independente" (MOORE, 2002).

Ao que tudo indica, a origem da limitação teórica da EAD reside nas limitações que afetam a própria pedagogia, 
incluídas as teorias de ensino e de aprendizagem. Nos inícios do século XX, Durkheim (1973, p.63-64) já observava que "as teorias chamadas pedagógicas" não passavam de especulações, de tentativas de determinar o dever ser da educação. "Não se propõem a exprimir fielmente certas realidades, mas a expor preceitos de conduta. Elas não nos dizem: 'eis o que existe e por que existe'. Mas, sim: 'eis o que será preciso fazer'."

Nossa discussão, por isso mesmo, trata inicialmente das abordagens teóricas endógenas ao campo da educação a distância, relacionando um conjunto de proposições que traduzem os esforços envidados no sentido de superar limitações epistemológicas relacionadas à EAD. Num segundo momento, discutimos a debilidade teórico-conceitual da EAD e sua dependência em relação aos modelos pedagógicos tradicionais. Num terceiro momento, problematizamos as bases teóricas da EAD a partir das suas interfaces, sobretudo, com a sociologia da educação. Finalmente, enfatizamos a industrialização do ensino como a abordagem mais abrangente para interpretar o fenômeno da educação a distância no mundo contemporâneo.

\section{CONCEPÇÕES E ABORDAGENS SOBRE A EAD}

Autores como Holmberg (1986) consideram a educação a distância uma disciplina científica, com implicações significativas tanto para o campo teórico quanto prático. Parte da literatura subscreve uma série de teorias formuladas com a finalidade de explicar o fenômeno que envolve a EAD (KEEGAN, 1990, 1998b; REKKEDAL, 1994; SIMONSON et al, 2003). A pressuposição levantada é que, como campo relativamente novo de estudo, seria 
importante à EAD definir-se e construir uma base teórica para a sua pesquisa, essencial aos avanços na área.

De acordo com Keegan (1991), retomado por Rekkedal (1994), esse processo teria se desenvolvido em quatro fases: o estudo da terminologia; o estudo da definição sobre o que compreende a EAD, inclusive, comparativamente à educação presencial; a natureza do campo de estudo, quando se chegou a propor o estabelecimento da EAD como uma disciplina científica específica; e, finalmente, o foco do campo de estudo, relacionado ao fato de que a EAD havia abandonado a comunicação face a face em favor da comunicação a distância.

As proposituras de abordagens teóricas seriam motivadas, então, pela convicção da necessidade de uma teoria específica para a EAD, capaz de equacionar seus problemas de identidade e debilidade científicas, falta de atenção aos fatores macros e impossibilidade de desenvolver hipóteses passíveis de verificação (SIMONSON et al, 2003). Contribui para isso o fato de as pesquisas em EAD terem uma tradição recente, remontando aos anos 1970. O volume das pesquisas cresceu significativamente, envolvendo diversas áreas específicas da EAD (HOLMBERG, 1986), mas - a despeito do aumento relativo do emprego de métodos qualitativos - sua qualidade é questionada, devido ao próprio caráter mais descritivo do que generalizável (REKKEDAL, 1994).

Segundo Keegan (1995 apud SIMONSON et al, 2003), uma teoria da EAD substancialmente fundamentada asseguraria a tomada de decisões políticas, econômicas, sociais e educacionais confiáveis, substituindo respostas ocasionais para os problemas apresentados em situações de crise que caracterizariam regularmente o campo da EAD. O autor é o responsável pela principal classificação das 
abordagens teóricas em EAD, divididas por ele em três grupos: teorias da independência e autonomia (helping organization, independent study e autonomy and distance); teorias da interação e comunicação (two-way comunication, guided didactic conversation, interaction and independence, continuity of concern e integrated mode); e teorias da industrialização do ensino (didactical analysis, industrial comparison e educational technology) (KEEGAN, 1991).

Uma síntese também relevante acerca das teorias existentes no campo da EAD foi realizada por Perraton (1988 apud SIMONSON et al, 2003), através de catorze hipóteses que levam em conta elementos da filosofia da educação e da teoria da comunicação e difusão. $\mathrm{Na}$ apresentação das abordagens relacionadas a seguir, tomamos como base, por um lado, as classificações de Keegan e de Perraton e, por outro, o estudo de Simonson et al que realiza uma densa revisão dos fundamentos teóricos tradicionais e emergentes no campo da EAD. Como o objetivo de nossa discussão neste capítulo é apontar o referencial teórico que mais satisfatoriamente dá conta do fenômeno da EAD no mundo contemporâneo, dispensamos atenção especial a algumas concepções e abordagens.

\section{Da "Teoria do Estudo Independente" à "Teoria da Reintegração dos Atos Pedagógicos"}

Charles Wedemeyer, um dos críticos dos padrões da educação superior, foi um dos principais autores a contribuir para a fundamentação teórica da EAD. Ele advogava que os conceitos antiquados de ensino e aprendizagem haviam falhado e que os modos de utilizar as tecnologias modernas poderiam redimensionar essa situação. A essência da EAD seria a independência do estudante - daí 
a preferência pela expressão e por uma "Teoria do Estudo Independente". O sistema deve possuir características que enfatizem o estudo independente e se apoiar em tecnologias para implementar essa independência.

Esse sistema caracteriza-se, sobretudo, pelo fato de ser capaz de operar, simultaneamente, em qualquer lugar onde haja estudantes e faltem professores; basear-se no ensino individualizado; atribuir maior responsabilidade na aprendizagem ao estudante; oferecer opções diversificadas de cursos e formatos; usar todas as mídias e métodos pedagógicos apropriados; preservar e aumentar as possibilidades de adaptação às diferenças do estudante, respeitando o seu passo de progressão e a liberdade de começar e parar o curso a qualquer hora. Os quatros elementos centrais do processo de ensino e aprendizagem aí envolvidos são o professor, o estudante, o meio de comunicação e algo a ser ensinado ou aprendido. O que se propõe é a reorganização desses componentes, objetivando garantir maior liberdade ao estudante. O desenvolvimento da relação estabelecida entre o professor e o aluno, todavia, deve ser a chave para o sucesso do sistema de EAD.

Nessa direção, formula Borje Holmberg a "Teoria da Conversação Didática Guiada" que, apesar de pretender ser uma teoria sobre a EAD (HOLMBERG, 1986), estaria situada no campo da teoria da comunicação (SIMONSON et al, 2003). Ela é desenvolvida, originalmente, com um foco nos cursos por correspondência e na comunicação individual, não dando muita atenção à comunicação em grupo. O pressuposto é que, em geral, o estudo a distância é uma atividade altamente individualizada e um exercício de independência envolvendo o próprio planejamento que acontece durante o tempo excedente de trabalho, sobretudo, de pessoas adultas capazes de decisão independente (HOLMBERG, 1986). 
Mesmo assim, assevera Keegan (1998a), considerando que a questão central é a capacidade do programa de envolver o aluno, em qualquer lugar onde esteja, em uma discussão educacional que se assemelha a uma conversação, a teoria representaria uma máxima para fomentar a EAD contemporaneamente, no ambiente virtual. A hipótese central da abordagem é que os estudantes preferem aprender e têm mais êxito quando estabelecem um ambiente de interação e concordância com os tutores, representando o curso constantemente um processo de comunicação em caráter de conversação (HOLMBERG, 1986). Essa conversação acontece em dois níveis: simulada, através do material didático produzido, e por intermédio da comunicação real e bidimensional que acontece durante o processo de aprendizagem (REKKEDAL, 1994).

Em meados dos anos 1990, a concepção é significativamente ampliada, compreendendo agora os seguintes pressupostos: a EAD serve para estudantes individuais e heterogêneos que não podem ou não fazem questão de cursar o ensino presencial; promove a liberdade e independência de escolha; constitui um instrumento para aprendizagem periódica ou continuada e acesso livre aos diversos interesses e oportunidades de aprendizagem; está centrada no apoio de meios de comunicação não contíguos; e está aberta ao behaviorismo, cognitivismo, construtivismo e outros modelos de aprendizagem (SIMONSON et al, 2003).

Focada igualmente na heterogeneidade do aluno, sob os auspícios de Michael Simonson, emerge nos Estados Unidos a "Teoria da Equivalência" que concentra seus estudos no impacto das novas tecnologias na educação a distância e nas condições de ensino e aprendizagem no ambiente da educação virtual. Baseia-se a teoria em 
valores, como controle local e instrução personalizada, caros ao sistema americano de educação tradicional. Defende a necessidade de que a EAD mantenha características importantes a esse modelo de educação, ao mesmo tempo em que tira proveito dos novos sistemas de telecomunicação.

A abordagem questiona a idéia de que a EAD deve prover situações instrutivas idênticas para todos os estudantes, não importa quando nem onde eles aprendam. A aprendizagem presencial e a distância seriam fundamentalmente diferentes, até mesmo quando tecnologias interativas são empregadas. Cada aluno deve ter, então, a liberdade de usar recursos ou estratégias instrutivas diversificadas ou atividades prescritas individualmente. Caso o curso de EAD seja projetado para disponibilizar experiências equivalentes, potencialmente os estudantes alcançarão os objetivos do programa.

Um dos elementos-chave à abordagem é o conceito de "equivalência". As experiências dos estudantes distantes e locais devem ter valor equivalente, embora possam ser bastante diferentes, devido a ocorrer em tempos e ambientes divergentes. Outro elemento fundamental é o conceito da experiência de aprendizagem. Parte-se da suposição de que, aprendendo em lugares e tempos diferentes, os estudantes necessitam de uma mistura de situações diversas. Alguns precisam de maior quantidade de observação, outros de uma dosagem maior de prática. A meta do planejamento deve ser antecipar-se e prover um conjunto de experiências satisfatórias para cada aluno ou grupo de estudantes. Diferentemente das tendências existentes, advoga-se finalmente que tanto os sistemas de comunicação sincrônicos como assincrônicos devem ser empregados, contanto que a meta de equivalência da 
aprendizagem seja cumprida. A questão chave, portanto, passa a ser: se as experiências equivalentes conseguem produzir resultados equivalentes (SIMONSON, entre 2000 e 2004).

A "Teoria da Liberdade Cooperativa" proposta por Morten Paulsen representaria, por sua vez, a primeira tentativa de desenvolver uma abordagem da EAD associada, especificamente, à comunicação mediada por computador (CMC). A concepção é influenciada pela teoria da andragogia e pelas categorias da orientação motivacional, sendo classificada como uma teoria da autonomia e independência. À primeira vista, a expressão liberdade cooperativa encerra contradição. Liberdade insinua autonomia, enquanto cooperação indica interação em grupo. Advoga-se que é possível desenvolver sistemas de EAD que combinem liberdade individual e cooperação, através de conferência por computador.

Parte-se, então, da noção de que a educação é uma arte cooperativa e que a tendência dos indivíduos é de interação voluntária, durante o processo de aprendizagem. Até mesmo o estudante solitário pode guiar o seu programa pessoal sem ajuda de instrutor, buscando, quando necessário, auxílio e encorajamento de outros colegas. Mesmo considerando o fato de a cooperação ser difícil em EAD, devido ao grande número de estudantes solitários e ao próprio desejo de liberdade, tem-se a convicção de que as novas tecnologias de comunicação foram desenvolvidas para facilitar a cooperação a distância.

A abordagem está preocupada, além disso, com as restrições impostas por parte dos programas estruturados à liberdade que considera elemento crucial à EAD. Cada vez mais, o estudante necessita de uma educação flexível que permita combinar, de forma satisfatória, trabalho, 
família e educação. Como a liberdade é uma construção complexa, possui características e dimensões fundamentais aos programas de EAD. Tais dimensões representam o chamado hexágono da liberdade cooperativa: liberdade de tempo, liberdade de espaço, liberdade de mídia, liberdade de acesso, liberdade de percurso e liberdade de currículo (PAULSEN, 1993).

Embora formule uma espécie de "Teoria da Dimensão Escolar da EAD", Benedetto Vertecchi não propõe exatamente uma teoria, como outros autores. A sua proposição "Elementi di una teoria dell'istruzione a distanza" ("Elementos de uma teoria da educação a distância"), publicada originalmente na revista Istruzione a Distanza (Serie Monografica 1, v.IX, n.8-9, mag./dic.1997), trata de analisar os elementos centrais de uma teoria da educação a distância, a saber, a dimensão escolar, a qualidade e a avaliação dos sistemas de EAD. A dimensão escolar ou educacional é aqui enfatizada porque, como sugere Keegan (1998a), representaria o fundamento teórico original ou essencial da abordagem de Vertecchi.

A abordagem parte do pressuposto de que o ciclo histórico que produziu uma forma generalizada de educação escolástica tende ao fim em si mesmo. Ainda que essa educação não tenha se tornado acessível a todas as camadas sociais e garantido um ensino satisfatório quantitativa e qualitativamente, não significa que se deva prolongar de forma indefinida o tempo gasto na escola convencional. A demanda crescente, sobretudo por parte da população adulta, para acompanhar e se atualizar ao ritmo acelerado das mudanças no conhecimento, acabou motivando a expansão dos sistemas de EAD, cuja característica essencial é sua possibilidade de romper com as limitações temporais e espaciais típicas à educação presencial. 
Contudo, todas as principais características que marcam o conceito tradicional de escola foram transformadas em características da EAD, desde a natureza da oferta educacional, a existência de um trabalho social docente, a confirmação de sua autoridade e a definição do papel do professor e do estudante, até a unidade de tempo e de local. Entre o século XIX e os anos 1960 do século XX, a didática dos programas de EAD permaneceu, essencialmente, organizando o estudo através da remessa regular de material de leitura e de exercícios, como imitação direta da didática dos currículos escolásticos. Daí a hipótese de que a EAD representa um tipo de educação escolástica, ou seja, uma das muitas variações históricas da escola convencional.

Em termos didáticos, a conseqüência dessa acepção é que a EAD não deveria ser confundida com um mero autoestudo nem com uma aprendizagem isolada. Pelo contrário, a distância aponta para uma condição física que se tenta superar, através de determinadas soluções, tais como, a simulação do processo educacional assumido pelos professores ou a própria recriação das condições funcionais de uma escola presencial. De sorte que os sistemas de EAD pressupõem a idéia de escola, isto é, uma instituição explicitamente organizada para ensinar algo a um determinado público, através de cursos que assumem o caráter de programas escolares, com a tarefa como quaisquer outros de administrar a cada estudante a aprendizagem necessária para alcançar a meta correspondente aos objetivos da escola.

O desenvolvimento dos sistemas de EAD representa, enfim, a criação de um ambiente educacional. Enquanto a educação convencional acontece em local determinado, o ambiente para o estudo a distância necessita ser criado. 
Os sistemas que não conseguem criar esse ambiente, cuja qualidade deve estar baseada na freqüência elevada das interações e na plena integração entre as características do estudante e a formulação de uma mensagem personalizada (VERTECCHI, 1998), estariam fadados ao fracasso (KEEGAN, 1998a). Isto porque não seriam capazes de prover, nem muito menos equacionar satisfatoriamente, a crucial questão da transação educacional (KEEGAN, 1998b).

A transação educacional, contudo, seria objeto de atenção desde antes de Michael Moore. Combinando a abordagem do estudo independente e o modelo da industrialização do ensino, Moore formula a "Teoria da Distância Transacional", como mais tarde tornou-se conhecida (JENSEN, 1998). Baseado em descrições sobre a aprendizagem autônoma como característica da maioridade (MOORE, 1986), a abordagem emerge como um método de classificação para programas de EAD, adaptado em parte ao estudo independente de adultos e à extensão universitária (SIMONSON et al, 2003). Surgida em 1972, conforme o próprio Moore (2002), sua concepção representaria a primeira tentativa em língua inglesa de uma teoria endógena à educação a distância.

O conceito de transação, desenvolvido inicialmente por John Dewey, define as correlações estabelecidas entre ambiente, indivíduos e padrões de comportamento numa determinada situação. Embora também aplicada à instrução presencial, a transação ocorre em um ambiente cuja característica essencial é "a separação entre alunos e professores que afeta profundamente tanto o ensino quanto a aprendizagem." (MOORE, 1986) Esse distanciamento faz surgir um espaço psicológico e comunicacional a ser transposto, isto é, a distância transacional que nunca é 
exatamente a mesma, estabelecendo-se em graus bem distintos entre um programa e outro de EAD.

A extensão da distância transacional em um programa depende, particularmente, de três grupos de variáveis que não são tecnológicas ou comunicacionais, mas típicos da interação entre ensino e aprendizagem - diálogo, estrutura e autonomia do aluno. O que implica dedicar especial atenção à estrutura e ao diálogo, as duas variáveis que combinadas constituiriam o cerne de todas as transações educacionais. Ambas deveriam ser utilizadas como conceitos básicos para organizar e analisar a EAD (MOORE, 1986). De forma um tanto paradoxal, quanto mais o programa é estruturado e menos estabelece diálogo, mais autonomia o aluno tem de exercer, sobretudo o adulto que, no estágio de maioridade em que se encontra, carrega consigo forte tendência à independência.

Na prática, porém, essa tendência desde sempre foi inibida e acentuada por um sistema escolar tradicional (MOORE, 2002). Além disso, as próprias necessidades, interesses e graus de autonomia variam de um aluno a outro, desde aqueles que exercem controle sobre o programa educacional e efetivamente decidem sobre sua experiência de aprendizagem até aqueles com maior dependência que buscam o programa de EAD para satisfazer uma necessidade emocional, como afeto, confiança e aprovação junto aos professores ou tutores. Cabe a estes não contribuir para que o apoio emocional acabe reforçando a dependência do aluno. Pelo contrário, considerando que a autonomia vai ser exercida direta e particularmente por um sujeito cuja experiência histórica de aprendizagem quase sempre lhe impôs uma acentuada ou relativa dependência em relação aos programas de EAD, a prioridade deve estar voltada para encorajar o aluno a 
adquirir as habilidades necessárias ao comportamento autônomo.

Significa, do ponto de vista pedagógico, que a aprendizagem é antes de tudo um processo com uma intenção e uma meta deliberada. Mesmo em situações de estudos autodirigidos, quando não recorre às orientações preparadas por especialistas, o próprio aluno necessita pôr em funcionamento uma série de atividades planejadas para resultar na mudança de conhecimento, comportamento ou atitude. Generalizando o conceito, não pode haver educação sem alguma forma de ensino, cuja característica essencial é envolver, pelo menos, duas pessoas em uma relação educacional deliberada. Seja dirigida seja autodirigida, toda e qualquer ação adquire caráter pedagógico quando apontada para apoiar deliberadamente um processo de aprendizagem.

A educação compreende, portanto, aprendizagem deliberada e ensino deliberado e a transação educacional acontece quando os programas pedagógicos e os programas de aprendizagem são reunidos. Idealmente, a educação deveria constituir, em última instância, uma interação perfeita entre as metas do aluno e as expectativas do professor, entre as estratégias necessitadas por um e os recursos oferecidos pelo outro, entre os critérios de cumprimento do programa que cada uma das partes considera aceitável. A negligência dessa interação, assevera Moore (1986), tem ocasionado freqüentemente a rejeição de programas e sistemas de EAD.

O estabelecimento de um processo de interação educacional apropriado à EAD é o que vai motivar Desmond Keegan, por seu turno, a formular a denominada "Teoria da Reintegração dos Atos Pedagógicos". A expressão está escrita propositalmente entre aspas porque, 
diferentemente de outros autores, Keegan (1986 apud SIMONSON et al, 2003) questiona a possibilidade de um paradigma teórico para a educação a distância, sobretudo tendo em vista que a EAD expressa uma contradição. Se a educação requer, antes de tudo, intersubjetividade uma experiência compartilhada através da qual professor e estudante são unidos por um laço comum, então, a EAD constituiria uma forma educacional contraditória. Instrução a distância seria possível, mas educação a distância não.

Considerando, ainda assim, que a EAD incluiria o ensino a distância (destacando-se o papel do programa ou tutor no processo) e a aprendizagem a distância (o papel do aluno no processo) (KEEGAN, 1998b), a preocupação fundamental da abordagem trata, justamente, de como reduzir a separação existente entre os atos pedagógicos, tanto em matéria de tempo quanto de lugar. A EAD deve ter como meta perseguir a reintegração de ambos os atos, visando reconstruir o momento em que acontece a intersubjetividade entre professor e estudante, a interação entre ensino e aprendizagem (SIMONSON et al, 2003). Nesse sentido, ganha importância capital o estabelecimento de duas estruturas paralelas de sistemas de EAD - o subsistema centrado no desenvolvimento do curso e o subsistema baseado no aluno. O problema é que grande ênfase sempre foi devotada ao primeiro subsistema, negligenciando a recriação dos atos pedagógicos, de importância essencial para o planejamento do sistema como um todo (KEEGAN, 1998a).

Com base nisso, a abordagem chega às seguintes hipóteses: a tendência dos estudantes é abandonar as instituições cujas estruturas não alcançam satisfatoriamente a reintegração dos atos pedagógicos; os estudantes 
enfrentam dificuldades para atingir uma aprendizagem de qualidade nessas instituições; e, por extensão, os estágios de aprendizagem aí alcançados podem ser questionados. O esforço de reintegração requer dos sistemas de $\mathrm{EAD}$, em primeiro lugar, materiais de aprendizagem projetados para se aproximarem o máximo possível à comunicação interpessoal. Em segundo lugar, quando os cursos forem ser ministrados, os atos pedagógicos devem mobilizar uma variedade de técnicas, incluindo os mais diversos meios de comunicação.

Paralelamente, aos sistemas tradicionais baseados na educação oral e em grupo, exigem-se mudanças de ordem estrutural, envolvendo a industrialização do ensino, a privatização da aprendizagem institucional, a organização administrativa, as instalações físicas e os princípios mais gerais (SIMONSON et al, 2003). Merece atenção especial, nesse caso, a problemática da privatização do ensino e da aprendizagem que reflete um fenômeno econômico-social marcante no mundo contemporâneo. A privatização da sociedade ocidental, caracterizada pela substituição do conceito de comunidade por uma ênfase na casa ou nas instâncias da vida privada, torna-se uma tendência crescente.

A aprendizagem, por natureza, quando não é institucionalizada é freqüentemente privatizada. A educação convencional sempre foi caracterizada tanto no mundo ocidental como oriental pela interação face a face entre professor e estudante e baseada no grupo de estudo. O problema é que, devido à complexidade dos níveis de preparação, inteligência e habilidade de aprendizagem de cada aluno, raramente os programas podiam ser ajustados às características individuais. Somente em meados do século XIX é que o desenvolvimento das tecnologias 
de comunicação tornou possível separar, em larga escala, o professor do estudante, o estudante do grupo e, finalmente, a aprendizagem em qualquer lugar e a qualquer hora.

Desde seu início empregando correspondência, a tendência marcante da EAD foi romper a estrutura tradicional e tratar os estudantes como indivíduos. Depois de um século e meio, a privatização da aprendizagem institucional é uma de suas características essenciais. Os sistemas de EAD tendem fazer com que o estudante troque as experiências em grupo por uma aprendizagem particular. Mesmo considerando sua contribuição fundamental ao recrudescimento da aprendizagem e do treinamento em grupo, o próprio ambiente virtual tem se mostrado um espaço intensamente destinado à aprendizagem privada.

O primeiro problema aí inscrito, chama atenção Keegan (1998b), é que a casa, o trabalho ou outro local privado não representaria um lugar privilegiado para aprender. Programas arrojados e caros falham, muitas vezes, porque o ambiente educacional necessário é simplesmente negligenciado. $\mathrm{O}$ segundo problema importante é que a privatização ou a individualização da aprendizagem não implica, automaticamente, no exercício da independência, da autonomia e da liberdade. Desde cedo, contudo, as definições em EAD tenderam a enfatizar as três categorias como imanentes ao estudante a distância. Quando analisados os programas existentes, esses conceitos na verdade traduzem um ideal. As estruturas inflexíveis são muito comuns nos sistemas e a independência, portanto, não é o elemento que a definição deveria refletir. O termo privatização seria muito mais pertinente a essa realidade. 


\section{“Teoria da Industrialização do Ensino"}

Um dos precursores do debate acerca dos fundamentos teóricos da educação a distância é o pensador Otto Peters, primeiro reitor da Universidade a Distância da Alemanha. Inspirado na Universidade Aberta do Reino Unido (AZEVEDO, 2001), a partir da década de 1970, o modelo das universidades a distância espalha-se por diversos países, levando até as últimas conseqüências o processo que Peters (2001) denomina de industrialização do ensino, representado em síntese pela "aplicação do princípio da produção em massa e do consumo em massa de bens ao ensino acadêmico." Exemplo disso é que, acentua o autor, as universidades a distância não demoram a se transformar em formadoras de centenas de milhares de alunos.

\section{A indústria do ensino e o Estado Industrial}

Antes de discorrermos sobre a "Teoria da Industrialização do Ensino", convém ressaltarmos alguns pontos significativos que se relacionam, direta ou indiretamente, a sua emergência. Um deles diz respeito ao fato de a mesma apoiar-se, em boa parte, na sociologia industrial, especialmente, de inspiração weberiana que contribui para entendermos como o processo de racionalização da indústria e da economia como um todo repercute sobre todas as esferas da sociedade capitalista, em particular, sobre o âmbito da educação e do treinamento burocrático-profissional. Outro ponto é que a concepção da "teoria" se dá, praticamente, no momento em que são publicadas duas obras importantes, tanto para o campo da economia como da educação, cujo paralelo com a 
abordagem da industrialização do ensino nos parece de extrema relevância.

Trata-se a primeira obra de "The New Industrial State" de John Kenneth Galbraith que, lançada originalmente em 1967 e publicada no Brasil com o título de "O Novo Estado Industrial", contribui para torná-lo "um dos autores centrais da segunda metade do século passado" (SUPLICY, 2006, p.621), exercendo forte influência em todo o mundo e "sobre a literatura brasileira de Ciências Sociais e de Economia em particular." (OLIVEIRA FILHO, 1985, p. XXIII) A segunda refere-se à "L'Industrie de l'enseignement" de Lê Thành Khôi, lançada em 1968 e reeditada em Portugal sob o título "A indústria do ensino", considerada pela Revue Tiers Monde do Instituto de Estudos do Desenvolvimento Econômico e Social da Universidade Paris 1 como o melhor ensaio sobre economia do ensino, até então, publicado em francês (LES ÉDITIONS, 2008).

"O Novo Estado Industrial" é um libelo em favor de três elementos, substancialmente, interligados - o planejamento, a tecnologia e a tecnoestrutura. A primeira tese levantada é que o sistema econômico constitui, por excelência, uma economia planejada, onde quem estabelece as regras não é mais o tradicional mercado, mas o sistema de planejamento formado pelas grandes empresas em estreita associação com o Estado que, cada vez mais, acomodam às suas necessidades e conveniências os mercados e a própria sociedade. Característica dominante e distintiva do Novo Estado Industrial, segundo Galbraith (1985, p. 19), o sistema de planejamento "é a parte da economia que, automaticamente, identificamos com a sociedade industrial moderna."

Com efeito, encontra-se em andamento uma crescente convergência entre os sistemas industriais privados e 
estatais em todo o mundo, do que resulta a segunda tese aventada: "Os imperativos da tecnologia e da empresa, não as imagens da ideologia, é que determinam a forma da sociedade econômica." (GALBRAITH, 1985, p. 17) A tecnologia permite à empresa libertar-se das adversidades e incertezas do mercado, submetendo-o a um planejamento rigoroso de preços, custos, produção e rendimentos. O sistema de planejamento, por essa razão, encontra sua força na competência técnica ou no uso ordenado seja do capital seja da tecnologia.

Tanto o planejamento como a tecnologia exigem mão-de-obra especializada, donde decorre a terceira tese. Cabe à organização - à burocracia empresarial ou estatal - conduzir o trabalho dos especialistas com a devida competência, objetivando um resultado ótimo, o que lhe confere enorme poder decisório no âmbito das empresas e da própria sociedade industrial moderna. Abrangendo todos os profissionais capazes de contribuir para a tomada de decisão em grupo, como denomina Galbraith (1985, p.272273), a tecnoestrutura é inevitável em um mundo caracterizado pelo avanço tecnológico e a produção em larga escala: "Ao comprometer-se com a tecnologia, o planejamento e a organização, o sistema de planejamento tornou-se profundamente dependente da mão-de-obra de que aqueles três elementos necessitam."

"Uma organização melhor aumenta a eficácia do trabalho e reduz as perdas de tempo e de energia", corrobora Khôi (1970, p.462). A tese central de sua obra "A indústria do ensino" é que, graças ao progresso científico-tecnológico e às injunções do crescimento, a educação não pode prescindir, como qualquer outra indústria, da maximização de seu rendimento, produtividade ou eficácia. “Eis porque nos propomos a aplicar a análise econômica 
à educação considerada como uma 'indústria' que, em virtude da combinação óptima dos 'factores de produção', deve maximizar a sua contribuição para o desenvolvimento econômico e social da nação." (KHÔI, 1970, p.5) Essa otimização dos fatores de produção - que deve ser obtida a um custo mínimo - pressupõe que se empreguem na sua planificação e gestão métodos da ciência e da tecnologia industrial, a começar pela análise precisa das necessidades a serem satisfeitas.

No bojo desses métodos, destaca-se a aplicação da tecnologia que passa a representar alternativa estratégica para responder ao problema da "explosão escolar" em todo o mundo. Sinal de que a sociedade industrial transformou o ensino, nem a escola nem seu "instrumento de produção" - o professor - representa mais a única instância a distribuir o saber, enfrentando o desafio de dividir essa função com a "máquina de ensinar" e as comunicações de massa ${ }^{3}$. Mais do que isso, a despeito de constituir a origem de grande parte do avanço técnico e científico, o ensino negligenciou a própria evolução e eficácia, deixando de introduzir no seu próprio seio inovações que revolucionaram a indústria e outros setores da economia. Em conseqüência da complexidade tecnológica, cabe à

3 A resistência às inovações pedagógicas, conforme Khôi (1970, p.318), não são apenas contraditórias, como também quase patológicas: "Quando os professores se manifestam contra a introdução da máquina na escola como significando a sua 'robotização', esquecem que, no sistema tradicional, uma grande, senão a maior, parte do seu tempo é ocupada mais com a 'vigilância' do que com a educação das crianças: a chamada, o controlo da disciplina, a classificação e a correcção dos deveres são tudo trabalhos que poderiam ser feitos de igual modo pela máquina." 
escola, em contrapartida, fornecer trabalhadores cada vez mais competentes.

Ainda que não se refiram um ao outro, Galbraith e Khôi coincidem num ponto que se afigura de extrema importância - a sociedade industrial, tornando a mão-de-obra especializada o fator decisivo da produção, pressupõe um sistema de ensino desenvolvido em moldes industriais. Reflexo de que a educação superior adapta-se em grau elevado às necessidades do sistema de planejamento é o prestígio assumido pelas ciências exatas e o próprio fato das faculdades de Administração de Empresa transformaram-se em "academias preparatórias para a tecnoestrutura." (GALBRAITH, 1985, p.269) Em outras palavras, considera-se o ensino como constituindo "a maior 'indústria' da nossa época, tanto pelos 'recursos' humanos e financeiros que absorve como pela importância da sua 'produção': os quadros administrativos, científicos e técnicos que desempenham um papel motor no desenvolvimento das sociedades actuais." (KHÔI, 1970, p.10)

Ao passo em que Galbraith confere ênfase ao planejamento, à tecnologia e à organização na sociedade industrial moderna, Khôi (1970, p.296) dedica sua atenção à racionalidade na educação: “As descobertas científicas e técnicas, que revolucionam a indústria, deviam ser aplicadas ao ensino a fim de lhe racionalizar e melhorar o processo e de o pôr à disposição do maior número possível de pessoas." A racionalidade do campo pedagógico, aliás, já chamava atenção de Max Weber nos anos 1910, ao discutir o autor "A 'racionalização' da educação e treinamento" como um fenômeno típico à burocratização da sociedade capitalista.

Conforme Weber (1994, p.37), o plano ou planejamento é essencial para determinar uma ação "economicamente 
orientada" que se refere às providências tomadas no sentido de satisfazer a necessidade de alcançar determinadas utilidades: “Denominamos 'gestão econômica' o exercício pacífico do poder de disposição que primariamente é economicamente orientado, havendo 'gestão econômica racional' quando tem caráter racional com referência a fins e de acordo com um plano." Não é toda ação racional quanto a seus meios que pode ser considerada, portanto, como gestão econômica racional, donde se faz necessário distinguir a técnica da economia.

Sem preocupação com o fim pelo qual se orienta, a técnica de uma ação representa a soma dos meios junto a ela empregados: "a técnica 'racional' significa uma aplicação de meios que, consciente e planejadamente, está orientada pela experiência e pela reflexão, e, em seu máximo de racionalidade, pelo pensamento científico." (WEBER, 1994, p.38) Apresenta-se uma questão técnica quando há dúvidas a respeito dos meios mais racionais aplicados a uma ação. O princípio do esforço mínimo ou do resultado ótimo, comparativamente aos meios empregados, pode ser usado como critério de racionalidade para a técnica e a economia, respeitada não obstante uma diferença de cunho essencial. Em se tratando da gestão econômica, importa sobremaneira que tais meios mostrem-se os mais econômicos possíveis relativamente ao esforço exigido.

A questão assume caráter econômico, por conseguinte, quando a ênfase recai sobre a comparação entre as finalidades, ou melhor, sobre o exame de custos - se os gastos despendidos serão compensados pela efetiva venda dos produtos. O que significa que a economia orienta-se, acima de tudo, pelo sentido ou fim empregado: "o fator principal para o desenvolvimento técnico é o condicionamento econômico; sem o cálculo racional como base da 
economia, isto é, sem condições histórico-econômicas de natureza extremamente concreta, não teria nascido a técnica racional." (WEBER, 1994, p.39-40)

A relação de uma ação social com a economia pode se estabelecer, no entanto, das formas as mais diversas possíveis. Podendo-se orientar desde resultados puramente econômicos, como o lucro, que fundamentam as comunidades econômicas, até a combinação de resultados econômicos e extra-econômicos que vão originar, por seu turno, as comunidades de gestão econômica. Considerando que a política, e as políticas públicas em geral, representam uma ação social no âmbito da gestão econômica, em particular: "Toda 'política' racional serve-se da orientação econômica em seus meios, e toda política pode pôr-se a serviço de fins econômicos." (WEBER, 1994, p.38)

Sendo assim, podemos considerar que "A 'racionalização' da educação e treinamento" implicaria a adoção de uma política racional, tanto orientada economicamente em relação aos meios quanto aos fins. Em princípio, essa racionalização está a serviço da superação das formas tradicionais de administração pública e privada. "A razão decisiva para o progresso da organização burocrática foi sempre a superioridade técnica sobre qualquer outra forma de organização." (WEBER, 1994, p.249) Do mesmo modo que a máquina suplanta as formas não mecânicas de produção, a "burocracia treinada" destaca-se frente às outras organizações pela maior precisão, velocidade, unidade, subordinação e, em particular, conhecimento profissional especializado que define seu caráter especificamente racional e cuja imprescimbilidade está condicionada pela economia da produção de bens e serviços.

Além de ter como base os documentos ou arquivos, para alcançar racionalidade plena na aplicação de normas 
e regras técnicas, a atividade burocrática exige qualificação profissional, cada vez mais, elevada, verificada através de exames e certificada por intermédio de diploma. A plena capacidade e disponibilidade de trabalho pressupõem treinamento especializado, incluindo o aprendizado técnico de um conjunto de regras relacionadas à administração e à jurisprudência, um conhecimento "vital para a existência econômica dos homens de negócios." (WEBER, 1963b, p.272)

Por outro lado, a burocracia já encerra em si uma atividade racional por excelência, dominada por regras, métodos e objetivos, cujos resultados se mostram os mais "revolucionários" possíveis em todo o mundo. "É a mesma influência que o avanço do racionalismo teve em geral. A marcha da burocracia destruiu as estruturas de domínio que não tinham caráter racional"' (WEBER, 1963b, p.282). À exceção da pequena associação ou organização, a burocratização torna-se inevitável à administração em larga escala de pessoas, bens e serviços.

A necessidade de uma administração contínua, rigorosa, intensa e calculável, criada historicamente pelo capitalismo - não só, mas, sem dúvida, principalmente por ele (este não pode existir sem aquela) - e que todo socialismo racional simplesmente seria obrigado a adotar e até intensificar, condiciona esse destino da burocracia como núcleo de toda administração de massas (WEBER, 1994, p.148). 
Os "modernos meios de comunicação", chama atenção Weber (1994, p.146), são cruciais à dinâmica da burocratização, uma vez que o estágio de desenvolvimento das condições técnicas de transporte e comunicação é uma condição decisiva para a administração, cuja precisão, ao mesmo tempo, depende e se vincula a esses meios "em extensão crescente." Como as decisões nas grandes empresas, sobretudo, baseiam-se na constância e rapidez das operações, o incremento da velocidade das comunicações é fundamental à dinâmica da administração que somente alcança resultado ótimo mediante uma rigorosa organização burocrática.

No âmbito do serviço público, os meios de comunicação exercem um papel sem precedentes na história: “O moderno Estado ocidental pode ser administrado pela forma atual apenas devido ao controle estatal da rede telegráfica, e porque o Estado tem a sua disposição os correios e ferrovias." (WEBER, 1963b, p.248) Além de servir ao avanço e maior desempenho da administração burocrática, esses meios e as tecnologias por eles envolvidas acabam sendo incorporados às políticas públicas, mais particularmente, aos programas e projetos na área de educação voltados para a formação inicial e continuada (incluindo o treinamento de pessoal) e envolvendo desde o antigo ensino por correspondência até a recente aprendizagem online. A atenção de Peters (1967), por isso mesmo, dirige-se a essa crescente racionalização do campo pedagógico, entendida pelo autor como um processo de industrialização do ensino representado, por excelência, pela educação a distância. 
As origens do "paradigma" industrial

A primeira análise teórica de Peters sobre a EAD acontece, em 1967, mediante a monografia "Das fernstudium an universitaten und hochschulen: didaktische struktur und vergleichende Interpretation: ein beitrag zur theorie der fernlehre" ("A educação a distância em universidades e faculdades: estrutura pedagógica e interpretação comparativa: uma contribuição à teoria da educação a distância"), cuja segunda parte, publicada em inglês como "Distance education and industrial production: a comparative interpretation in outline" ("Educação a distância e produção industrial: esboço de uma interpretação comparativa"), tornou-se mais conhecida (PETERS, 1967).

Em 1973, o autor aprofunda sua conceituação sobre a industrialização do ensino, publicando o livro "Die didaktische struktur des pernunterrichts: untersuchungen zu einer industrialisierten form des lehrens und lernens" ("A estrutura pedagógica da educação a distância: investigação sobre uma forma industrializada de ensino e aprendizagem"), cuja versão compacta em inglês recebe o título de "The educational principles of distance education: research into an industrialized form of teaching and learning" ("Princípios da educação a distância: investigação sobre uma forma industrializada de ensino e aprendizagem") (PETERS, 1994).

Os estudos de Peters sobre o ensino a distância começam com uma análise didática que concebe a EAD como campo da educação e não como uma modalidade de ensino. A análise da estrutura didática da EAD baseia-se no modelo proposto por Paul Heimann e Wolfgang Schultz, o qual enfatiza que todos os processos de ensino-aprendizagem podem ser interpretados à luz de seis elementos estruturais intrínsecos: objetivos, conteúdos, métodos, escolha dos meios, pré-requisitos humanos e 
pré-requisitos sócio-culturais. A conclusão de Peters, ressalta Keegan (1991, p.76), é "inescapable", demonstrando que a EAD e a educação convencional são essencialmente diversas em relação a cada um dos seis componentes constituintes do processo educacional. O que comprovaria que os teóricos da educação haviam enfatizado o ensino direto, especialmente em sua forma presencial, oral e baseada em grupo, excluindo o outro componente do contexto educacional - o ensino indireto, do qual o ensino a distância representaria um dos seus elementos.

Em 1967, Peters já acentuava que, por mais que se tentasse explicar o fenômeno do ensino a distância (uma das terminologias mais empregadas à época) e identificar as características que o diferenciavam de outras formas de prover conhecimento, a terminologia educacional não era suficientemente endógena (PETERS, entre 2000 e 2004). Apesar de ser ofertado por instituições particulares desde o século XIX e se distinguir do estudo presencial, esclarece mais tarde o autor, na década de 1960 a EAD ainda era praticamente ignorada pela pedagogia, ou em última instância, descrita a partir de categorias pedagógicas tradicionais insatisfatórias que a definiam, meramente, como uma forma especial do ensino tradicional.

A atenção dispensada àquilo que havia de essencial à EAD levou o autor a reconhecer diferenças estruturais em relação à educação presencial, revelando-se notória a influência de uma variável socioeconômica - o impacto da industrialização. A substituição crescente da produção artesanal de bens e serviços pelo processo industrial provocara uma mudança radical também na educação. Contrariamente ao ensino convencional, de responsabilidade do Estado e destinado à educação e formação dos cidadãos, o ensino a distância é ofertado por empresas que objetivam empreender e expandir seus negócios, obtendo 
o máximo de lucro: "o ensino tornou-se um produto que podia ser alterado e otimizado, e sobretudo vendido, e de maneira muito típica - não apenas localmente, mas em qualquer parte, assim como um produto manufaturado industrialmente." (PETERS, 2001) O alvo eram as pessoas insatisfeitas com os modelos tradicionais de ensino e predispostas à aplicação dos novos métodos de produção ao processo de aprendizagem.

Como explica o próprio Peters (1967), embora tome como referência autores como Weber (1951) - que definira as similaridades entre os institutos de pesquisa e as organizações capitalistas ${ }^{4}$ - e Plessner (1924) - para quem a mecanização, metodização e despersonalização do processo industrial presidiam tanto a vida econômica como cultural -, a interpretação comparativa entre a educação a distância e a produção industrial teria finalidade apenas heurística. O conceito de industrialização do ensino, na verdade, não se referia ao emprego automático de "princípios da industrialização, mas, sim, à analogia entre o processo de ensino e aprendizagem e o processo da produção industrial. Em ambos estão concentradas todas as características constitutivas, interligadas em seqüência sistemática." (PETERS, 2003b, p.203).

4 No caso de Weber, a referência remete a uma conferência pronunciada na Universidade de Munique, Alemanha, em 1918, em que o autor chama atenção para o seguinte fato: "Ultimamente, podemos observar distintamente que as universidades alemães nos amplos campos da ciência evoluem na direção do sistema americano. Os grandes institutos de Medicina ou Ciências Naturais são empresas 'capitalistas estatais', que não podem ser administradas sem consideráveis recursos. Vamos encontrar, no caso, a mesma situação predominante sempre que a empresa capitalista entre em cena: a 'separação entre o trabalhador e o seu meio de produção'." (WEBER, 1963a, p.156) 
A pretensão não era comparar diretamente os dois processos, mas utilizar de forma experimental elementos estruturais, conceitos e princípios derivados da teoria da industrialização para interpretar o fenômeno da EAD. Ademais:

A análise sociológica baseada na filosofia alemã relativamente às noções de comunidade e sociedade parte de Weber, Tonnies e Habermas, evidenciando que a educação tradicional, via oral e baseada no grupo, segue a categorização comunitária, enquanto a educação a distância tem a ver com o grupamento social. Em termos gerais, as estruturas comunitárias são amigáveis e baseadas na comunidade; a sociedade implica uma estrutura social mais abrangente e hostil. $\mathrm{O}$ processo de comunicação no âmbito desses dois grupamentos sociológicos indica que tanto a intersubjetividade como a reciprocidade da comunicação interpessoal na educação convencional é radicalmente diferente da liberdade de espaço e da comunicação mecanizada da educação a distância. A possibilidade de alienação não se encontra afastada (KEEGAN, 1991, p.79, tradução nossa).

A "Teoria da Industrialização do Ensino" toma como ponto de partida a premissa de que, enquanto a educação tradicional e convencional compreende formas pré-industriais, a educação a distância caracteriza-se eminentemente 
por condições industriais de ensino. Por causa dessa diferença, adverte Peters (1967), as condições estruturais da educação tradicional não são completamente adequadas para descrever e analisar a EAD. Empregar conceitos convencionais seria, neste caso, correr o risco de enxergar uma nova forma de educação à luz de uma perspectiva antiga, distorcida e superficial. Em se tratando do ensino presencial, "estamos diante de atos comunicativos que surgiram da cultura oral herdada e que por isso são originais. O ensino a distância, no entanto, somente é possível com base em atos racional-objetivos, instrumentais e estratégicos, que têm que ser transmitidos através da tecnologia." (PETERS, 2003b, p.204)

As formas como se organiza a educação a distância seriam, substancialmente, compatíveis com os princípios e tendências do processo de industrialização, não constituindo coincidência alguma que a EAD houvesse iniciado seu desenvolvimento em meados do século XIX, como requeriam as condições que só existiram dali em diante. Por isso mesmo, as leituras, seminários e atividades práticas derivadas da retórica antiga e exercitadas nas universidades medievais, assim como o colóquio da era humanística, representariam formas pré-industriais de ensino. Quando mais adiante se reconhece que o apoio técnico a distância é fundamental para atender grandes grupos de estudantes, torna-se evidente que a EAD "é uma forma complementar de estudo para a nossa era industrial e tecnológica." (PETERS, 1967, tradução nossa)

Aliás, acrescenta Peters (1994), os sistemas de EAD só diferem relativamente dos princípios da industrialização na fase de aplicação. Na verdade, eles ocorrem de forma acentuada nos chamados sistemas de modo simples que operam apenas com métodos a distância. Mesmo assim, 
nos sistemas duais que combinam aprendizagem a distância com métodos de ensino face a face, a divisão de trabalho, a mecanização, a organização e outras características também se fazem presentes, em menor ou igual proporção. Os sistemas duais, em suma, são industrializados, mesmo ainda mantendo traços do ensino convencional, como padrões e rotinas que não foram totalmente substituídos por procedimentos artificiais de planejamento educacional.

De certa forma, a análise comparativa proposta pela abordagem industrial transcende o âmbito da EAD, estendendo-se ao sistema de educação como um todo. O que permite adicionar a explicações baseadas em conceitos educacionais tradicionais uma definição mais precisa sobre a complexidade da EAD:

A educação a distância é um método racionalizado - envolvendo a divisão de trabalho - de prover conhecimento que, devido à aplicação dos princípios da organização industrial e do uso extensivo de tecnologia, facilita a reprodução da atividade pedagógica a inúmeras pessoas, permitindo a um grande contingente de alunos participar de estudos de forma simultânea, independentemente do lugar de moradia e de trabalho (PETERS, 1967, tradução nossa) ${ }^{5}$.

5 Na publicação em lingua inglesa, a definição é expressada da seguinte forma: "Distance study is a rationalized method - involving the division of labour - of providing knowledge which, as a result of applying the principles of industrial organization as well as the 
Em uma dimensão mais ampla, conforme Peters (1994), a educação a distância difere do ensino presencial por causa da aplicação intensiva dos seguintes princípios e características industriais: racionalização, divisão de trabalho, mecanização, linha de montagem, produção de massa, trabalho preparatório, planejamento, organização, mudança e especialização de funções, métodos de controle científicos, formalização, padronização, objetivação, concentração e centralização.

\section{Características industriais da EAD}

A "racionalização" constitui primeira e principal característica do processo de industrialização do ensino. De modo geral, compreende a adoção racional ou metódica de medidas com o propósito de alcançar - comparativamente às formas artesanais - uma maior produção, com mais baixo dispêndio de energia, tempo e capital. As descobertas científicas, inclusive, devem estar voltadas para o uso prático, objetivando melhorar os resultados dos processos econômicos e técnicos de produção.

Embora o modo racional de pensar e agir não seja novo à educação em geral, na EAD determina que as atitudes e procedimentos somente possam ser estabelecidos após a racionalização acentuada da industrialização da produção (PETERS, 1967). A racionalização se estabelece na EAD, acrescenta Keegan (1991, p.76), quando o conhecimento e as habilidades de um professor são transmitidos para um

extensive use of technology, thus facilitating the reproduction of objective teaching activity in any numbers, allows a large number of students to participate in university study simultaneously, regardless of their place of residence and occupation." (PETERS, 1967) 
número teoricamente ilimitado de estudantes, mediante a objetividade de um curso de qualidade constante.

A "divisão de trabalho", por sua vez, baseia-se no fato de que o processo de produção como um todo, antes restrito a uma única pessoa, é reunido em vários procedimentos elementares (PETERS, 1967). Enquanto o artesão planeja, organiza, usa ferramentas e vende o produto que fabrica, na produção industrial essa unidade é dividida em várias funções, aumentando a especialização da mão de obra e fazendo surgir os departamentos de pesquisa e desenvolvimento, produção, marketing, vendas e outros do gênero. Na EAD, a divisão de trabalho permitiu a oferta de estudo a distância em larga escala, com maiores vantagens do que o ensino presencial.

O papel do professor é reduzido a um especialista em conteúdo que deixa de exercer a maioria das tarefas de planejamento e desenvolvimento instrutivo, repassadas a outros profissionais, como desenhistas de programa, especialistas em mídia e peritos em avaliação. Uma organização burocrática coordena, então, as várias funções atribuídas na educação convencional ao professor e boa parte do processo de ensino e aprendizagem se realiza, sem a intervenção deste último. Os tutores e conselheiros ocupam funções nos sistemas de EAD bem definidas e submetidas a um planejamento prévio, controle por parte de uma supervisão central e orientação de programas ou materiais preparados por outros profissionais. Em tais circunstâncias, seu trabalho também é industrializado.

$\mathrm{O}$ desenvolvimento das máquinas e equipamentos, também, assume importância capital no processo de industrialização. A "mecanização" compreende o emprego de máquinas em um processo de trabalho, cujo propósito é substituir a força física de animais e homens, 
livrar estes da dura rotina do esforço manual e tornar a produção eficiente (PETERS, 1994). Há graus variados de mecanização, sendo seu nível mais avançado caracterizado pela expansão da automação, desde as unidades de planejamento e produção até os setores de controle e avaliação (PETERS, 1967).

Na verdade, a educação a distância não poderia acontecer sem o emprego de máquinas. As primeiras escolas por correspondência foram fundadas, ao mesmo tempo, em que eram instaladas as ferrovias e os sistemas postais. Até mesmo nas formas mais simples de EAD já se observam tendências para os elementos estruturais da industrialização, com ênfase para um ou mais dispositivos técnicos que substituem funções do professor em certas áreas de trabalho, como na oferta de informação e avaliação do desempenho. Torna-se, então, imprescindível o apoio logístico dos sistemas de transporte e meios de comunicação usados como mídia para difundir a instrução (PETERS, 1994).

Duplicando tais sistemas, essas condições constituem o elemento prévio para o desenvolvimento e expansão da EAD, tomando a forma posteriormente de modernos meios de comunicação e processamento eletrônico de dados (PETERS, 1967). Em contrapartida, conduzem aos riscos de um modelo tecnológico de educação a distância, com ênfase em dispositivos técnicos, fragmentação e compartimentalização do processo de aprendizagem, enfim, no predomínio de uma racionalidade técnica em detrimento da racionalidade crítica (PETERS, 1994).

A "linha de montagem" é caracterizada, por seu turno, pelo fato de que o trabalhador permanece no seu ambiente de trabalho, ainda que as peças produzidas possam ser transportadas de um lugar a outro até a produção final. 
Na educação a distância, esse processo é particularmente notável. No desenvolvimento dos programas de EAD, enquanto os materiais de estudo passam de um setor responsável a outro, são feitos ajustes e modificações específicas em cada fase.

A "produção de massa" daí resultante indica uma característica estrutural do capitalismo avançado. Marca isso a formação de uma sociedade de consumo, cuja elevação do padrão de vida está diretamente relacionada ao fato de que a indústria é capaz de produzir bens de consumo em grande quantidade e, geralmente, acessíveis. Por natureza, a produção de massa só é possível de existir onde há uma grande e suficiente aglomeração de consumidores. $\mathrm{O}$ que requer do processo de produção, ainda, um sistema de transporte eficiente para estabelecer a conexão entre produtor e consumidor, muitas vezes distantes, e de pesquisas de mercado para ajustar os produtos aos padrões e exigências de consumo.

Além de transformar o professor e o estudante em produtor e consumidor de bens e serviços educacionais, a produção em EAD também representa produção de massa. Em primeiro lugar, porque o efeito da multiplicação dos cursos provocado pelo avanço da tecnologia e dos meios de comunicação dispensa que professor e aluno necessitem se encontrar no mesmo local geográfico. Em segundo lugar, porque se torna possível transportar conhecimentos e habilidades pedagógicas a um número ilimitado de estudantes. Em terceiro lugar, porque a produção de grande quantidade de cursos força as instituições de ensino a avaliar as exigências dos estudantes e a melhorar a qualidade de seus programas mais cuidadosa e freqüentemente do que no ensino tradicional. 
Em quarto lugar porque, graças as suas semelhanças com o processo de produção industrial, os governos passam a reconhecer na EAD um meio mais adequado e eficaz de prover ensino a grandes contingentes de estudantes do que os mecanismos convencionais permitiriam. Finalmente porque, de acordo com o princípio da produção de massa, a educação a distância poderá igualar as oportunidades de estudo exatamente como a indústria tem absorvido os padrões de consumo, tanto na cidade como no país. Análogo à elevação no padrão de vida, isso permitiria um aumento geral no nível de educação que, de outra forma, poderia não ser alcançado.

Em uma situação na qual prevalece a divisão de trabalho, a economia, a qualidade e a velocidade dos processos de produção dependem da sua prévia preparação. Sobretudo, em indústrias que produzem uma variedade de artigos que necessitam ser concebidos por profissionais qualificados em departamentos especializados. Durante o "trabalho preparatório", determinam-se como os trabalhadores, máquinas e materiais podem se relacionar em cada etapa do processo de produção. Quanto mais preparado o processo de produção, menos o seu sucesso depende das habilidades particulares dos trabalhadores envolvidos, permitindo inclusive a substituição destes.

Nos sistemas de EAD onde se desenvolve uma variedade de cursos, o sucesso dos programas também depende decisivamente de uma fase preparatória. À semelhança da indústria, a EAD requer mais investimento nessa etapa do que a educação convencional. Participam da fase preparatória especialistas em diversas áreas, com qualificação, muitas vezes, mais elevada do que a dos professores. Comparados aos docentes do ensino presencial que são responsáveis por todo o processo pedagógico, os tutores 
ou conselheiros a distância podem ser, inclusive, facilmente substituídos. Os estudantes, por sua vez, acabam realizando um curso testado antes de ser distribuído, o que previne erros e facilita o melhor direcionamento dos alunos.

Componente essencial da fase preparatória, o "planejamento" precisa ser mais inclusivo e detalhado no processo industrial do que na produção artesanal, pois requer a coordenação de muitos fatores que interagem. Existem dois tipos de planejamento: o efetivo que consiste em escolher as alternativas mais vantajosas e prever os dados do desenvolvimento futuro; e o planejamento por contingência, o qual responde às situações em que mudanças econômicas acontecem de repente.

Na educação a distância, a intervenção de tutores ou conselheiros durante a realização dos cursos é bastante ilustrativa do planejamento por contingência que suplementa o efetivo. Este, por sua vez, diz respeito a todos os esforços envidados para predeterminar e organizar ao máximo os processos de desenvolvimento dos programas em EAD (PETERS, 1967). Os vários especialistas trabalham em projetos que estão submetidos a um planejamento anteriormente detalhado (PETERS, 1994).

O planejamento concentra-se, em grande parte, na "organização" do ciclo de produção que compreende a realização de ajustes gerais e permanentes, objetivando orientar as atividades produtivas. Como conseqüência da divisão de trabalho, o processo de produção necessita ser ordenado da forma a mais racional possível, de acordo com os princípios e métodos organizacionais especialmente desenvolvidos. A produtividade, inclusive, depende do tipo e grau de organização da produção. 
Na EAD, ocorre igualmente uma correlação imediata entre a eficiência do método pedagógico e a organização racional. Por um lado, a aplicação rigorosa de princípios e métodos organizacionais poupa os professores e alunos de envidar esforços desnecessários. Por outro, a coordenação dos sistemas de EAD torna-se mais fácil quando pessoal treinado e métodos organizacionais modernos, inclusive de conteúdos, são alocados (PETERS, 1967). O trabalho dos especialistas é coordenado por procedimentos burocráticos, organizados pela administração central dos sistemas (PETERS, 1994).

Justamente com o processo de produção industrial acontece, também, a "mudança e especialização das funções" do trabalhador que conduz a uma diferenciação profissional bastante demarcada. Quando o trabalho preparatório e a venda foram separados da produção, atribuindo várias funções a indivíduos diferentes, o trabalho realizado por uma única pessoa perdeu sua função. Além disso, foram criados outros papéis e tornadas possíveis novas práticas funcionais.

As funções também mudam na EAD. O papel original do professor de provedor do conhecimento é transformado em autor da unidade de estudo, enquanto a função de aconselhamento é atribuída a outra pessoa. Os tutores ou conselheiros, por sua vez, assumem mais intensamente tarefas destinadas à motivação do estudante, apoio individual e identificação de problemas. Também aqui, ao mesmo tempo, uma perda é compensada por um ganho de função, através do qual pode ser alcançado um nível de qualidade quase inacessível no ensino tradicional.

O taylorismo descreve as atividades de analisar, monitorar e testar a produtividade do processo de trabalho, sistematicamente e nos mínimos detalhes, como a aplicação 
à administração de "métodos de controle científicos" da engenharia. $\mathrm{Na}$ EAD, esses procedimentos são exercidos pelas comissões de especialistas responsáveis em analisar cientificamente o desempenho dos sistemas (PETERS, 1967). Como os programas de EAD são resultado da cooperação de especialistas, a sua eficácia pedagógica não pode ser julgada da mesma maneira como realizada pelo professor em sala de aula (PETERS, 1994). Necessita ser feita por peritos em avaliação, mediante o emprego de métodos e técnicas de pesquisa que podem monitorar a qualidade de um curso em qualquer tempo, registrar a reação dos estudantes e apontar a forma mais adequada de melhorar a sua eficiência.

Graças à divisão de trabalho e à mecanização no processo industrial, faz-se necessário que as várias fases de produção sejam predeterminadas formalmente, muito mais do que na produção artesanal. A ênfase na "formalização" é que torna possível estabelecer a cooperação entre todos os envolvidos no processo de produção, notadamente, quando cada uma das partes tem necessidade de confiar no trabalho prévio conduzido de acordo com um planejamento formal. $\mathrm{Na}$ EAD, todas as etapas do ciclo de estudo devem ser predeterminadas formalmente, desde as tarefas de aprendizagem até as formas de comunicação e os mecanismos de avaliação dos cursos.

A "padronização", igualmente, é característica essencial de uma situação de produção que envolve divisão de trabalho e alta tecnologia para fabricar vários exemplares de um produto, torná-los mais aceitáveis, baratos e fáceis de serem substituídos. A aplicação do mesmo princípio força os sistemas de EAD a adotar um maior grau de padronização do que aquele requerido no ensino convencional. 
Da mesma maneira que a produção de um produto industrializado só se apresenta econômica se sua qualidade é constantemente adaptada a um grande grupo de consumidores, as instituições de EAD têm que unificar os conteúdos de seus cursos de tal modo que possam atrair, tanto quanto possível, a todos os alunos igualmente. A conseqüência dessa adaptação a um modelo ideal de estudante é que os conteúdos acabam refletindo bem mais as exigências objetivas do perfil do curso que os interesses específicos de professores e estudantes.

Quanto mais o processo de produção é determinado por mecanização, métodos de controle científicos e princípios organizacionais, reduz-se a dimensão subjetiva que caracterizava, essencialmente, o trabalho do artesão. O elevado grau de "objetivação" na era industrial chegou ao máximo com a produção automatizada, onde o envolvimento humano no decorrer do processo de produção foi eliminado em grande parte.

Na educação a distância, a objetivação também provocou seus reflexos, dificultando ao professor exprimir sua subjetividade como no ensino convencional. A objetivação do ensino a distância ganha especial interesse, todavia, em sociedades caracterizadas por uma relação tradicional entre professor e aluno, marcada pela preservação da hierarquia, ou mesmo, subordinação do segundo ao primeiro. Como a EAD aboliu em grande parte a subjetividade, é mais difícil ser afetada por situações desse tipo e é particularmente adequada à educação continuada de adultos.

Sem a objetivação, ademais, os programas de EAD não poderiam ser reproduzidos e disponibilizados em qualquer tempo e lugar nem controlados e aprimorados continuamente (PETERS, 1967). A “coisificação" transforma 
o ensino em objeto que pode ser manipulado, adaptado, modificado, multiplicado, emprestando-se plenamente à produção, aperfeiçoamento e divulgação em massa. Sua forma estruturada torna-se extremamente valorizada, em particular, nos casos em que "uma mass higher education, como é considerada necessária em alguns grandes países industrializados desde os anos 70 e 80, sequer é possível sem esse tipo de oferta de ensino." (PETERS, 2003b, p.92)

Igualmente ao processo de alienação na indústria, causado pela rígida divisão de trabalho, as pessoas envolvidas nos sistemas de EAD tendem a ser alienadas pelas atividades rotineiras e as responsabilidades limitadas. Acentua-se, além disso, a alienação dos estudantes quando confrontados com artefatos técnicos em lugar de seres humanos. Ao invés de estudar em um modelo de instrução baseado na interação pessoal, são impelidos a fazer parte de um processo de ensino e aprendizagem predominantemente despersonalizado. $\mathrm{Na}$ EAD, "normalmente existem, entre docentes e discentes, em virtude do grande número de participantes, da ampla anonimidade dos docentes, da objetivação das funções didáticas e sua aplicação técnica, apenas relações sujeito-objeto." (PETERS, 2003b, p.80)

As relações pessoais, com efeito, tornam-se indiretas e perdem muito da sua realidade. Um sentimento de isolamento e frustração, que, às vezes, toma de assalto os estudantes, pode ser decorrência dessa desumanização da aprendizagem. Segundo Weber (1951), retomado por Peters (1994), isso é sintomático da racionalização crescente da sociedade que conduz, irresistivelmente, ao desencanto com o mundo. A propósito, particularmente importante a Holmberg (1986) seria libertar a EAD de seus elementos de anonimato e impessoalidade. 
O investimento necessário ao processo de industrialização conduz o empresariado, por sua vez, a se preocupar com a "concentração" de capital, "centralização" administrativa e monopolização dos mercados (PETERS, 1967): "as instituições de educação a distância têm uma tendência à monopolização no âmbito de um Estado ou da oferta nacional de educação." (KEEGAN, 1991, p.77) Nesse cenário, não soa nada estranho que um pequeno grupo de sistemas de EAD consiga alcançar grandes contingentes de estudantes.

Muito mais vantajoso economicamente do que construir pequenas instituições regionais é montar um grande estabelecimento central, capaz inclusive de cruzar as fronteiras nacionais, do mesmo modo que os mercados industriais conseguem expandir em larga escala seus produtos (PETERS, 1967). O que permite, também, aos grupos políticos dominantes alargar sua influência até um sistema industrial centralizado de EAD, com o risco de ser usado para manipular e instrumentalizar as pessoas de modo sutil e bem mais eficiente (PETERS, 1994).

\section{A EAD ENTRE O MODELO DE SOCIEDADE INDUSTRIAL E PÓS-INDUSTRIAL}

Ao que tudo indica, a observação de Laaser (1997) de que a EAD ainda não haveria produzido teorias endógenas e, por conta disso, adotaria os modelos tradicionais de ensino e de aprendizagem, ainda prevalece nos inícios do século XXI. A revisão dos princípios e características das propostas de abordagens teóricas, acima relacionadas, indica-nos o emprego de elementos conceituais e categorias de análise que se constituiriam em objetos centrais das teorias de Skinner, Rotkopt, Ausubel, Bruner, Rogers, 
Gagné e Egan. O que implicaria inferir, ponderando inclusive a debilidade teórico-conceitual da EAD enquanto campo científico (DEVLIN, 1989; RUMBLE, 1988), que aquelas abordagens representariam muito mais aplicações dessas teorias à prática da educação a distância.

Considerando que nosso estudo tem como objetivo mais amplo analisar o discurso da política nacional de educação a distância, o que sobressai dentre as concepções e abordagens relacionadas é, especialmente, o "paradigma" industrial. Comparativamente às teorias da independência e autonomia e às teorias da comunicação e interação, a abordagem acerca da industrialização do ensino tende a encerrar a perspectiva de análise mais abrangente para compreender o fenômeno da EAD no mundo contemporâneo. Como diria Peters (1967), levando em conta o contexto mais geral da EAD, isso significa submeter à investigação uma área que tinha sido omitida regularmente pelas análises didáticas tradicionais. As demais abordagens, com as devidas exceções, acabariam funcionando como complementares ao modelo industrial que aponta, por excelência, para as condições estruturais dos sistemas de $\mathrm{EAD}$, cabendo àquelas, sobremodo, a tarefa de ajudar a construir a contra-hegemonia no processo de ensino e de aprendizagem, através da criação de espaços de independência, diálogo e autonomia, baseados em princípios políticos, filosóficos e éticos.

Uma das principais vantagens da noção de industrialização do ensino, por sinal, estaria no mérito de transcender o campo da educação e analisar o fenômeno da EAD sob uma perspectiva sócio-econômica, como produto e processo da modernidade. Os sistemas administrativos e redes de distribuição em EAD constituiriam, por excelência, processos de produção característicos de sociedades 
modernas, com desenvolvida produção, administração e consumo de massa. No fundo, a análise apontaria para um debate crucial à segunda metade do século XX, compreendendo os modelos teóricos que tentam dar conta da sociedade contemporânea - o fordismo, o neofordismo e o pós-fordismo. Além de ser de fundamental importância para as políticas públicas orientar seus regulamentos, estruturas institucionais e práticas, a problemática do que e como a sociedade aprende é um produto das decisões tomadas com base em tais paradigmas (SIMONSON et al, 2003).

A polêmica em torno da aplicação dos modelos fordista, neofordista e pós-fordista, emprestados da sociologia industrial para explicar as transformações capitalistas e, em particular, as tendências e perspectivas da educação a distância, intensifica-se nas décadas de 1980 e 1990. Mais precisamente, envolve a revisão da "Teoria da Industrialização do Ensino", a principal abordagem teórica presente na literatura internacional. Esse debate, destaca Peters (2001), ganha relevância "porque o aspecto da industrialização não se encontra na literatura pedagógica com referência a nenhuma outra forma de aprendizagem e ensino."

Uma crítica contundente à concepção de Peters foi encampada por membros da The Open University, a Universidade Aberta do Reino Unido que, segundo o autor, caracterizaria um sistema exemplar estruturado com base em práticas fordistas (BELLONI, 1999, p.10). O problema crucial da abordagem seria empregar os princípios e características do modelo industrial fordista, derivado da concepção de Henry Ford sobre a produção em larga escala de automóveis para consumo de massa que prevaleceu no Ocidente, desde as primeiras décadas do 
século XX, e se estendeu a todo o mundo. O fordismo está baseado nos princípios da baixa variabilidade do processo de produção, baixa inovação dos produtos e baixa responsabilidade do trabalho como um padrão ideal de produção eficiente que guia a estratégia organizacional (SIMONSON et al, 2003). Constituindo-se, assim, no paradigma central dos modelos teóricos e das práticas da economia que, sob a égide do intenso desenvolvimento capitalista no pós-guerra, influencia os outros campos da vida social.

O modelo industrial vai orientar as políticas governamentais, organizando os serviços públicos de modo racionalizado, planejado e em larga escala, ou seja, em bases fordistas. No campo da educação, o fordismo influencia a universalização da educação fundamental e média, o planejamento centralizado, a construção de grandes unidades e a otimização de recursos. "Faz também parte deste quadro o surgimento de uma nova disciplina, que irá transpor para os processos educacionais os modelos industriais: a tecnologia educacional." (BELLONI, 1999, p.13) Aplicado à educação a distância, o modelo implica na divisão de trabalho, produção e consumo de massa, organização, controle e distribuição centralizados dos programas, com os cursos sendo desenvolvidos por um pequeno grupo de especialistas.

A partir dos anos 1970, sobretudo, as recessões econômicas e as mudanças no capitalismo iriam apontar que o fordismo - baseado na produção e num mercado de massa uniforme - não se adaptaria mais a uma sociedade em rápida evolução, com elevado nível de competitividade, diversificação da demanda, expansão e uso intensivo de tecnologia avançada. A redução do custo-benefício e do custo-eficiência dos sistemas fordistas (SIMONSON et al, 
2003) assinalaria, sintomaticamente, que aquele modelo industrial não mais garantia sucesso operacional e estava fadado ao esgotamento, exigindo a urgente reestruturação do próprio modo de produção capitalista (BELLONI, 1999, p.14).

Com base nisso, reclama-se a necessidade da EAD em se ajustar às transformações que afetam o mundo da produção e do trabalho nas sociedades industrializadas, cuja tendência seria implantar processos de neo-industrialização e pós-industrialização (PETERS, 2003b, p.206). "A maioria dos estudiosos concorda que os objetivos e as estratégias de $\mathrm{EaD}$ estão sendo (ou devem ser) redefinidos em função de análises e críticas orientadas pelos paradigmas pós-modernos e desconstrucionistas." (BELLONI, 1999, p.11)

O neofordismo, de inspiração japonesa, é o primeiro modelo daí resultante. Embora preserve o princípio fordista de baixa responsabilização do trabalho, aposta na alta variabilidade do processo de produção e na alta inovação dos produtos. No que diz respeito aos impactos sobre a EAD, destaca-se a divisão da administração entre uma instituição central e os escritórios regionais ou locais que permite maior flexibilidade no desenvolvimento e na oferta dos cursos (SIMONSON et al, 2003), mais contatos sociais e atendimento de pequenos grupos de estudantes. "Os cursos de ensino a distância, na verdade, continuariam sendo desenvolvidos pela central no sistema de divisão de trabalho, mas a produção em massa seria consideravelmente reduzida. A organização do ensino seria feita no próprio lugar de sua realização." (PETERS, 2003b, p.213)

O pós-fordismo avança além disso, apostando também na alta responsabilização do trabalho, o que sugere 
um trabalhador altamente qualificado e capaz de tomar decisões. Uma distinção fundamental comparativamente às formas fordista e neo-fordista que tendem a provocar a desqualificação do operariado, graças ao excesso de especialização e segmentação do processo de produção através de atividades rotineiras. O pós-fordismo acaba se revelando como modelo do capitalismo do futuro, de caráter mais justo e democrático.

A partir dos anos 1980 e 1990, quando se acentuam o processo de globalização da economia, a expansão das tecnologias de informação e comunicação e seus consideráveis impactos na vida política, social e cultural, a lógica industrialista cederia lugar a uma organização industrial pós-fordista, um modelo menos tecnocrata e mais humanista (BELLONI, 1999, p.12). Tomando como base uma divisão de trabalho informal e flexível e uma administração democrática e participativa (SIMONSON et al, 2003), o pós-fordismo romperia com as tradicionais estruturas industriais burocratizadas e hierarquizadas. Prevaleceria, a partir de então, um processo de horizontalização e descentralização gerencial, organização empresarial, terceirização da produção com base em pequenas empresas empreendedoras e ênfase na autonomia, iniciativa e flexibilidade dos sujeitos envolvidos.

Além de buscar a integração entre os modos de educação presencial e de educação a distância, um modelo pós-fordista de EAD teria de ser, necessariamente, focalizado no aluno em lugar do programa e no controle de qualidade deste, outorgando aos professores o desenvolvimento dos cursos, currículos e métodos de acordo com as demandas dos estudantes. Os sistemas de produção industriais, portanto, seriam mais flexíveis, com design 
direcionado às demandas dos consumidores, altamente segmentados em um mercado de proporções globais.

O problema é que a aplicação do modelo neo-fordista ou pós-fordista à educação a distância poderia, em contrapartida, correr o risco de acabar representando uma mera adaptação dos sistemas de EAD aos novos imperativos do sistema capitalista e do mercado globalizado. Com o corolário de que os discursos sobre as potencialidades democráticas e emancipatórias dos novos modelos de EAD funcionariam como álibi para legitimar, no campo da educação, a nova fase do liberalismo (BELLONI, 1999, p.22). Além de colocar em questão a sustentabilidade dos sistemas de EAD, incluindo o aumento dos custos para atender um contingente elevado de alunos, a concepção pós-industrial apresenta debilidade, uma vez que "não está comprovada sua influência sobre transformações sociais e industriais. Por isso não parece justificar-se o otimismo no sentido de se estabelecer, com o auxílio dela, formas de produção democráticas." (PETERS, 2003b, p.217-218)

Na realidade, já chamava atenção Edwards (1991 apud BELLONI, 1999, p.22), especialmente os programas de aprendizagem aberta, destinados à formação individualizada e flexibilizada no próprio local de trabalho, não seriam tão progressistas quanto aparentavam. Muito embora se propusessem a formar uma força de trabalho qualificada e com múltiplas competências, eles favoreceriam o controle por parte dos empregadores do treinamento profissional e da educação continuada, fornecendo a base teórica e a legitimação da mudança propugnada pelo pós-fordismo. Além disso, o postulado de uma força de trabalho multicompetente para construir um modo de produção aberto, democrático e com autonomia do trabalhador, afetaria apenas uma minoria da classe 
trabalhadora, submetida inclusive a se responsabilizar pela própria formação, tarefa para a qual a maioria não se encontraria tão preparada.

Em se tratando da EAD, adverte Peters (entre 2000 e 2004), embora a individualização da aprendizagem represente novas oportunidades para a didática e permita que o estudante autônomo deixe de ser uma ilusão, a autodeterminação do indivíduo também depende da sua capacidade de avaliar o conteúdo ofertado e o apoio ao processo de planejamento de sua aprendizagem. Planejar e direcionar os próprios estudos pressupõe considerável experiência metacognitiva e perspicácia didática, pois não basta apenas construir, transformar ou aprofundar as estruturas cognitivas, "mas, sim, também a simultânea reflexão desse processo." (PETERS, 2003b, p.95-96) Ainda assim, "como num passe de mágica, o desemprego estrutural e o enfraquecimento do peso relativo do fator trabalho, elementos essenciais do capitalismo tardio, e as políticas que os favorecem, são deslocados da esfera pública para a esfera privada, individual." (BELLONI, 1999, p.24)

Considerando, todavia, a tendência inflexível dos sistemas reais de EAD, a consequente privatização da aprendizagem não implicaria obrigatoriamente no pleno exercício da autonomia por parte do indivíduo em relação ao seu estudo (KEEGAN, 1998b). No próprio ambiente virtual, conforme sugere Moore (2002), a despeito de preexistir um considerável potencial para a relação multilateral, o diálogo intensivo, o estudo independente e em grupo e a construção coletiva de conhecimento, dependeria sobremodo de "professores progressistas" a criação de oportunidades não apenas para a redução da distância transacional, como também para a ampliação da autonomia dos alunos. O que não se deve ignorar, complementa 
Peters (2003b, p.209), é que tais relações somente podem ser oportunizadas à medida que outras funções pedagógicas permanecem submetidas e conduzidas por um sistema de produção industrial que tende influenciar, significativamente, a maneira como os professores ensinam e os estudantes aprendem.

\section{Mudanças estruturais na EAD}

A insistência de Peters (2003b) em uma interpretação estrutural da educação a distância sugere-nos uma constatação extremamente importante. Os "conceitos didáticos" (PETERS, 1994) focados no processo de ensino e aprendizagem, desde o estudo independente até a distância transacional, dariam conta, particularmente, de uma das complexas dimensões do fenômeno da EAD - o campo da didática. Aquele autor acaba propondo, todavia, para o próprio avanço da EAD, a necessidade de instaurar o "primado da didática", especialmente, uma didática integrada da educação a distância, sincrética em termos de modelos teóricos, explicativos e avaliativos e capaz de fazer face ao seu "boom de desenvolvimento" e a uma fase de "transformação jamais vista".

Uma didática de tal ordem facilitaria o replanejamento da educação a distância na era da informação e da comunicação, ajudaria a relativizar o primado tecnológico e serviria como uma espécie de metaciência para a cooperação acadêmico-científica em torno da EAD. "Ela poderia ajudar as muitas correntes de educação a distância, surgidas nos últimos quinze anos nos países em desenvolvimento, na transmissão de orientação, transparência estrutural e instrução para o agir reflexivo." (PETERS, 2003b, p.27) Considerando sobretudo a influência dos valores 
pós-modernos na estrutura didática da EAD, a aprendizagem aberta e orientada para a ação, proposta pelo pós-industrialismo, mostrar-se-ia bem mais compatível às novas concepções existenciais do que os cursos de EAD de bases fordistas, evidenciando dessa forma como as tendências pós-industriais e pós-modernas seriam complementares.

$\mathrm{O}$ autor considera, inclusive, o ambiente virtual de aprendizagem como o evento histórico-cultural mais importante para o campo da didática na atualidade (PETERS, entre 2000 e 2004). Depois de se ocupar, durante mais de trinta anos, das características estruturais dos sistemas e práticas em EAD, acentuando de todo modo seu potencial sem igual para democratizar a educação superior (THE EDITORS, 2003) e assim desempenhar "uma forte missão humanitária" (PETERS, 2001), a preocupação mais recente de Peters (199-, 2003a, entre 2000 e 2004) concentra-se no impacto das novas tecnologias de informação e comunicação junto ao ensino a distância.

Um dos motivos dessa atenção é que as análises educacionais estariam relacionadas, normalmente, aos processos de ensino e aprendizagem que ocorriam nos espaços reais, envolvendo os atores, conteúdos, métodos, recursos didáticos e resultados pedagógicos, ignorando os espaços nos quais eles aconteciam. A existência "material", a qualidade e as características dos espaços e o seu efeito sobre os processos de aprendizagem ganhariam importância, à medida que se problematiza a substituição dos ambientes tradicionais de ensino pelos espaços virtuais de aprendizagem, rompendo "um modelo cultural universal" (PETERS, 199-). Na realidade, até que as telecomunicações promovessem o renascimento da aprendizagem face a face, contígua e em grupo, os estudiosos da educação a distância tenderam a ignorar esse componente inerente ao campo (KEEGAN, 1998b). 
Baseadas na capacidade das tecnologias e sistemas de comunicação interativos, as mais recentes proposições teóricas asseguram que a EAD não é uma forma de educação diferenciada da educação presencial nem se trata de um campo distinto da educação, devendo utilizar as teorias educacionais tradicionais. As abordagens consideram que, embora aconteça em lugar diferente, a EAD pode ocorrer em tempo simultâneo, enfatizando a criação de experiências equivalentes tanto para o estudante presencial como para o aluno distante (SIMONSON, entre 2000 e 2004). Reflexo disso também é que, por um lado, o papel dos sistemas de EAD convencionais é desafiado pela aprendizagem aberta que acontece sem a influência de uma organização educacional (SIMONSON et al, 2003) e, por outro, a comunicação intensiva acentua as possibilidades de aprendizagem em grupo e as interações entre estudantes e professores (REKKEDAL, 1994). Combinando comunicação assíncrona e menos estrutura, o computador permite respeitar o próprio tempo e ritmo de estudo de cada indivíduo, algo que não existia nem na EAD nem na educação em geral (MOORE, 2002).

Em "A educação a distância em transição", a posição essencial de Peters (2003a, p.187) relativamente às tendências e desafios da EAD parece muito próxima, inclusive, àquelas de seus críticos de orientação pós-fordista ou pós-modernista. Concorda ele que, para preparar os indivíduos a se inserir no contexto da economia do conhecimento, em um ambiente virtual de aprendizagem o desafio fundamental deverá ser promover uma pedagogia centrada no estudante. Capaz, portanto, de oferecer experiências de aprendizagem interativas, colaborativas, autônomas e autodirigidas, cabendo ao próprio aluno planejar, organizar, controlar e avaliar todo o processo. 
Segundo ainda Peters (entre 2000 e 2004), esse fato representaria uma mudança fundamental da cultura do ensino para a cultura da aprendizagem, instaurando uma nova era educacional, sobretudo, no que tange à aprendizagem individual e independente que estaria se tornando, cada vez mais, flexível, variável, adaptável, disponível e acessível. A extensão das mudanças no ensino e na aprendizagem behaviorista constituiria o grande sintoma desse processo, principalmente quando se considera que acontecem nos espaços virtuais, onde estariam assumindo a maioria das funções dos professores. O behaviorismo seria deslocado do centro do ensino, cedendo lugar ao desenvolvimento de sistemas não lineares, nos quais, por um lado, a complexidade da aprendizagem é evidenciada e, por outro, a descoberta e exploração do conhecimento é apoiada e desenvolvida.

A opção em adotar uma perspectiva didático-pedagógica e humanista para o fenômeno contemporâneo da educação a distância não significa, em todo caso, que o autor tenha abandonado a interpretação industrial da EAD. A bem da verdade, ele chega à conclusão de que, se a aprendizagem moderna pode ser descrita como behaviorista, linear, causal, lógica, hierárquica, sistemática, centrada e com o currículo fechado, o espaço virtual desenvolver-se-ia, até certo ponto, em contraste a isso e poderia ser considerado, na sua essência, como pós-moderno. Embora construído de forma lógica, seu currículo apresentar-se-ia aberto e orientado por um modelo de aprendizagem construtivista, não-linear, não-causal, associativo, o que contribuiria para debilitar o papel das instituições de educação convencional.

Ressalva o autor, no entanto, que a existência da educação virtual não deveria ser considerada por si só como 
uma reforma ou renovação estrutural do ensino e da aprendizagem. Ao lado de ganhos de natureza pedagógica, mediante a geração de possibilidades que não seriam encontradas nos espaços reais, haveria perdas de substância didática, não importa quão abundantemente a EAD estivesse equipada com tecnologias que a ajudassem a se modernizar. Os novos ambientes de aprendizagem - contrariamente àqueles tradicionais - não poderiam ser buscados junto a um edifício educacional ou escola virtual, mas em algum lugar ou espécie de cosmo de aprendizagem virtual. São ambientes que estariam essencialmente separados uns dos outros, isto é, espaços de instrução, informação, comunicação, colaboração, exploração, documentação, simulação, enfim, espaços na realidade virtuais e que não existiriam de fato.

O "real" para o estudante seria apenas o ambiente virtual de aprendizagem, com a tela do monitor como interface. Os espaços virtuais só são efetivamente criados e integrados quando o vazio imaginado atrás da tela é transformado em um teatro "imaginário" de ações educacionais (PETERS, 199-). Na prática, além de não haver ambiente real de aprendizagem, não existe também parceiro algum estudante ou professor fisicamente real, nenhuma contextualização espacial e temporal, enfim, a dimensão histórica encontra-se, praticamente, "ausente no modo como teve efeito no ensino e na aprendizagem tradicionais." (PETERS, 2003a, p.190)

Outro problema é que, como foi interiorizado há muito tempo o modo como a aprendizagem behaviorista acontece no espaço real, inconsciente ou subconscientemente, haveria uma tendência em projetar esse modelo até o ambiente virtual. Ademais, as novas tendências dos espaços virtuais, que alteram e ajustam a educação 
convencional aos imperativos da sociedade pós-industrial (PETERS, entre 2000 e 2004), só terão êxito quando se dispensar a devida atenção as suas características específicas e reconhecer exatamente suas vantagens e desvantagens educacionais e pedagógicas (PETERS, 199-). Não deixa de estar aí implícita uma preocupação de ordem estrutural, motivada pela importância crescente da logística nos novos sistemas de EAD.

Em conseqüência da anulação das distâncias e do tempo, as mídias e os métodos a elas aplicados acabam sendo fortemente consolidados (PETERS, entre 2000 e 2004), causando impactos didático-pedagógicos sem precedentes: rápida transmissão de informação, melhor qualidade dos programas, maior interatividade e mais orientação aos alunos (PETERS, 2003a, p.24).

Embora a ênfase na tecnologia possa ser compreendida como uma forma de determinismo, não se pode incorrer no equívoco oposto, que consistiria em minimizar sua importância, pois hoje mais do que nunca os progressos técnicos dão forma aos processos sociais e econômicos (ou modelam-nos), agora de globalização, de transformação das relações de tempo e de espaço e outros tantos que se situam no interior de um processo maior que é a reestruturação do capitalismo contemporâneo, com a flexibilização dos processos e mercados de trabalho, e a variabilidade de produtos e padrões de consumo (BELLONI, 1999, p.20). 
Mesmo em pretensos tempos pós-modernos, ao que tudo indica, não é recomendável abandonar as categorias de análise da industrialização do ensino quando se pretende dimensionar as condições atuais de desenvolvimento da educação a distância. Não por acaso, já reconhecia Paulsen (1993), ainda que servisse como guia para a implementação de programas de EAD, o hexágono da liberdade cooperativa (liberdade de tempo, espaço, mídia, acesso, percurso e currículo) sofreria sérias dificuldades para se efetivar na prática. Primeiro, os recursos escassos e regulamentos rígidos costumavam inibir a flexibilidade dos sistemas de EAD. Segundo, além de ser difícil combinar com um modelo industrial de educação, a liberdade individual praticamente não poderia competir em termos de custos com a educação de massa industrializada.

Há pouco mais de uma década atrás, Raggatt (1993), citado por Peters (2003b, p.202), também reconhecia que instituições como a Universidade Aberta do Reino Unido, onde trabalhava, reproduziam as características da industrialização do ensino. Aplicavam, plenamente, os princípios da divisão de trabalho, automação, organização, emprego de métodos e produtos padronizados. Em 1997, o próprio Peters deparava-se com traços do ensino industrializado nas maiores universidades a distância do mundo. Mesmo considerando alguns avanços nas suas estruturas didáticas, uma das principais conclusões de sua pesquisa é que, na maioria dos casos, a aprendizagem autônoma ainda se desenvolvia gradativamente, dependendo inclusive de comprovação empírica. "A rigor, portanto, o Empire State College é a única universidade a distância que pode ser chamada de aberta com toda justiça, embora não inclua em sua denominação esse epíteto atualmente tão em moda." (PETERS, 2003b, p.379) 
Naquele mesmo ano de 1997, ao publicar na França o livro "Cibercultura", Lévy (2000, p.169-170) não perde a oportunidade de se posicionar contra as tendências de massificação da educação que considera "uma resposta 'industrialista' ao modo antigo, inadaptada à flexibilidade e à diversidade necessárias de agora em diante." Chama atenção o autor, por isso mesmo, que toda política educativa precisa dar ênfase ao ciberespaço, "o mediador essencial da inteligência coletiva da humanidade". Dentre outras razões, porque suas possibilidades técnicas "já foram amplamente testadas e experimentadas" e as escolas virtuais "custam menos" do que as convencionais.

Embora tenham em vista, ao mesmo tempo, as "aprendizagens personalizadas e a aprendizagem coletiva em rede", baseadas na "pedagogia cooperativa" e no "ensino da sociedade por ela mesma", a nova "economia do conhecimento" e o "mercado da competência", preconizados por aquele autor, não deixam de se inscrever ou encerrar a face avançada do mundo industrial. O modelo que o inspira a dar ênfase às "árvores de conhecimentos" 6 parece representar, inclusive, muito mais do que apenas "um método informatizado" para gerenciamento das competências em nível global.

Os especialistas nesse campo reconhecem que a distinção entre ensino "presencial" e ensino "a distância" será cada vez menos pertinente, já

6 Também chamadas "árvores de competências", explica Lèvy (2000, p.177), "são uma marca registrada da Trivium S.A. Elas crescem graças ao programa Gingo, desenvolvido por essa mesma empresa." 
que o uso das redes de telecomunicação e dos suportes multimídia interativos vem sendo progressivamente integrado às formas mais clássicas de ensino. A aprendizagem a distância foi durante muito tempo o "estepe" do ensino; em breve irá tornar-se, senão a norma, ao menos a ponta de lança. De fato, as características da aprendizagem aberta a distância são semelhantes às da sociedade da informação como um todo (sociedade de rede, de velocidade, de personalização etc.). Além disso, esse tipo de ensino está em sinergia com as "organizações de aprendizagem" que uma nova geração de empresários está tentando estabelecer nas empresas (LÉVY, 2000, p.170).

Mesmo não concordando, em princípio, com a diferenciação entre a educação convencional e a EAD, Vertecchi (1998) acaba confirmando a forte racionalização desta última, ainda que adaptada aos imperativos da sociedade contemporânea. Ao tratar da organização e da estratégia didática, o autor logo acentua como cruciais aos sistemas de EAD o trabalho preparatório, a administração, o planejamento, a especialização e a tecnologização, além do caráter orgânico e padronizado do projeto educacional que substitui o modelo uniforme que traduzia as particularidades do professor no ensino presencial. Segundo ele, muitas das dificuldades que afetam o desenvolvimento contemporâneo da educação a distância estariam relacionadas às conseqüências de interpretações ideológicas 
da modernização, o que tornaria necessário analisar os aspectos estruturais da EAD em detalhes.

A análise de Keegan (1998) acerca das tendências e perspectivas logísticas e didáticas dos sistemas de treinamento a distância da União Européia para o século XXI, também, vêm corroborar a interpretação industrial. A primeira constatação do autor é a presença e, em alguns casos, até a acentuação de processos de industrialização, mecanização, privatização, individualização e globalização regendo os sistemas. A segunda constatação é que, devido às interfaces existentes, as normas didáticas, os indicadores de sucesso e fracasso e as abordagens teóricas tradicionais à EAD, incluindo a noção da alienação potencial dos sujeitos, conforme esboçada por Peters, poderiam ser transferíveis ao treinamento baseado na web. A última constatação é que, somando-se a sua própria concepção de privatização institucional da aprendizagem, o conceito de industrialização do ensino apresentava-se crucial à análise dos sistemas a distância, em particular, àqueles destinados ao treinamento e ao emprego em massa, o que demonstrava a importância da abordagem industrial na contemporaneidade.

Nos inícios da presente década, embora prefira adotar uma perspectiva interacional, Fausto Neto (2001, p.25) constata que o programa brasileiro TV Escola segue o dispositivo clássico de "transmissão-recepção", sendo ofertado na forma de um "pacote" hermeticamente fechado; isto é, além de sua produção processar-se "na esfera técnico-política e de especialistas, sem maior interferência das bases pedagógicas das escolas, se trata de um conjunto de instruções, regras e normas que são repassadas sistematicamente pela esfera da produção às escolas."

Sintomático também é o fato de que, mais recentemente, ganhou notoriedade a proposta de uma nova 
universidade virtual e global, concebida como modelo de um mundo pós-industrial. Acontece que a observação mais atenta acerca da proposta acaba se deparando com idéias que reafirmam, constantemente, as características essenciais à industrialização do ensino: “Um modelo industrial de gerenciamento eficiente foi introduzido nas universidades. Hoje, elas são vistas como provedoras de serviços de informação, e os alunos, como clientes." (TIFFIN; RAJASINGHAM, 2007, p.189-190)

Por último, ressaltamos o livro "Educação a distância: uma visão integrada", de Moore e Kearsley (2007). Como mais precisamente sugere seu título original em inglês, "Distance education: a systems view" ("Educação a distância: uma visão sistêmica"), a EAD é tratada como um sistema composto, principalmente, pelos subsistemas que envolvem a tecnologia, o ensino, a aprendizagem, a criação, o gerenciamento, a política e a organização. Conforme os autores, seja em uma instituição com centenas de milhares de estudantes, seja em uma pequena escola de EAD, "tem de existir um sistema" que envolva, entre outros, os seguintes elementos (os quais não deixam de referir características de um modelo industrial): um subsistema para a estruturação dos cursos; um subsistema para a transmissão dos cursos; um subsistema de controle e avaliação dos resultados; e "uma organização com uma política e uma estrutura administrativa para ligar essas peças distintas." (MOORE; KEARSLEY, 2007, p.12-13).

Respondendo a críticas a sua concepção, o próprio Peters (1994) já salientava que o emprego do modelo de produção industrial à EAD representava uma novidade e, para alguns, mostrava-se até mesmo indesejável. Além de acentuarem que a interpretação industrial não se sustentava em meio a uma sociedade em fase de pós-industrialização, seus críticos alegavam que algumas características 
da industrialização, como a divisão de trabalho, a especialização e a alienação, já se faziam presentes na própria educação presencial. Como esclarece Peters (2003b, p.204), as influências da industrialização sobre esse campo de ensino são apenas acessórios externos: “No fundo, ele continua sendo realizado de acordo com os mesmos modelos estruturais da época pré-industrial."

As críticas mais contundentes, todavia, são as que apontam a concepção industrial como anacrônica (KEEGAN, 1990, p.80-81). Reconhecem elas que a abordagem teria prevalecido nos anos de surgimento das primeiras universidades abertas e ainda se justificaria quando aplicada à década de 1970, porém, depois da "desilusão" dos anos 1980, perdera muito de sua relevância. Segundo Peters (1994), a industrialização do ensino e da aprendizagem constituiria, porém, apenas uma pequena parcela de uma enorme mudança social que modificou e continuaria a alterar, profundamente, a vida da sociedade. Ademais, seria ledo engano considerar que a tecnologização da educação teria atingido seu ponto máximo nos anos 1970.

Para democratizar os sistemas educacionais, preconiza o autor, a sociedade deverá enfrentar até maiores impactos. Da mesma maneira como não será possível alimentar, vestir e oferecer habitação a toda população dos países em desenvolvimento sem industrialização, não será possível também universalizar a educação. A industrialização do ensino, pois, representaria um processo de dimensões históricas e antropológicas duradouras e não apenas o resultado de uma década de reformas entusiásticas. "De fato, as sociedades industrializadas encontram-se agora num período de neo ou pós-industrialização. Mas quando se analisa a maioria das universidades de ensino a distância, ver-se-á que elas ainda aplicam princípios da industrialização." (PETERS, 2001) 
O autor levanta a hipótese de que, na realidade, o que está em emergência é a configuração da segunda mudança estrutural na EAD. A primeira mudança refere-se à passagem da aprendizagem tradicional para a aprendizagem a distância, ou melhor, para a "óbvia e conseqüente" industrialização do ensino que continua a exercer influência, sobretudo, entre as universidades abertas. A segunda mudança, por sua vez, trata da passagem da aprendizagem a distância para a aprendizagem online, ou melhor, do deslocamento dos espaços de aprendizagem reais para os ambientes virtuais de aprendizagem.

Além de não se restringir a uma substituição da "velha mídia" por uma "nova mídia", essa mudança colocaria em questão o próprio modelo institucional e pedagógico que predominou na educação a distância, particularmente, no final do século XX. Os conteúdos, os métodos e a natureza do conhecimento científico tendem a ser modificados e os programas de ensino, cada vez mais, ganhar características interculturais e globais. No fundo, o que indica essa mudança é que as noções de aprendizagem pós-industrial e pós-moderna vão se estreitando e deverão influenciar o futuro da EAD. Ainda assim, ressalva Peters (2003b, p.228), "ambas só poderão ser implementadas mediante novas instituições voltadas ao ensino a distância, porque nas estruturas institucionais e administrativas já estabelecidas das teleuniversidades existentes isso promete revelar-se como especialmente difícil."

A segunda mudança estrutural do ensino a distância, portanto, para ser capaz inclusive de democratizar a educação continuada, talvez apenas possa se concretizar plenamente nas condições ideais "de uma sociedade informatizada do conhecimento." (PETERS, 2003a, p.385). $\mathrm{O}$ que implica reconhecer, em todo caso, que se encontra em evidência um novo processo de mudança estrutural 
da EAD, motivado pela expansão e reestruturação da própria industrialização. "Refiro-me à transição da mecanização para a automação em ambientes de aprendizagem digitalizados." (PETERS, 2001)

O que precisamos salientar, finalmente, é que o modelo teórico adotado por Peters demonstra ser imprescindível ao próprio entendimento das mudanças estruturais por que passa a educação a distância. Primeiro, o autor formula o conceito de industrialização do ensino a partir de uma interpretação comparativa entre a educação presencial e a EAD que caracteriza a estrutura industrial desta última. Segundo, aborda a natureza do processo de digitalização do ensino com base em uma interpretação comparativa entre os espaços de aprendizagem reais e virtuais que enfatiza as potencialidades da estrutura didática destes últimos.

Ainda assim, a noção de industrialização do ensino, em momento algum, parece ser abandonada. Pelo contrário, além da própria primeira mudança estrutural na EAD alicerçar a segunda, a interpretação que tenta dar conta do processo de digitalização da educação depende e se inscreve, justamente, no contexto analítico da industrialização do ensino, cuja base conceitual transcende o âmbito pedagógico em que aquela se circunscreve. O que nos leva a concluir que, notadamente, numa sociedade capitalista em processo intensificado de globalização, as mudanças estruturais na EAD encontram-se, cada vez mais, diretamente associadas às próprias reestruturações de suas bases produtivas, em particular, de suas condições industriais. 


\section{ESCAVANDO O TERRITÓRIO DA ANÁLISE DE DISCURSO}

Neste capítulo, visando responder à complexidade do fenômeno em estudo, articulando-o aos objetivos, à problemática e às questões da pesquisa, como forma de sustentar a tese aqui delineada, adentraremos ao território da Análise de Discurso (AD) de orientação francesa. Sobretudo porque permite esta compreender o discurso como um modo crítico de pensar, constituído pela "memória do dizer", que autoriza intervir o contexto histórico-ideológico, em condições de produção e situações de enunciação específicas, numa dada conjuntura social. Ao elegermos metodologicamente a AD como dispositivo analítico, somos tentados a postular, a priori, que o discurso da política nacional de educação a distância - como todo discurso - não seria transparente, mas atravessado por discursividades que se repetem, a partir de novas formulações, novas condições de produção, constituindo efeitos de sentidos como resultado de confrontos, conflitos e jogos, cuja forma e funcionamento mantêm conexão com as ideologias que estiverem circulando no tecido social.

Percorrendo as fundações desse território pantanoso, em que se encontram atalhos, vestígios e inflexões, é possível trazer à superfície as condições e as particularidades 
da emergência geográfica e temporal da $\mathrm{AD}$ e sua estabilização em contextos diferenciados, vendo que a memória discursiva se atualiza em lugares multifacetados, sem perder de vista o movimento da história. A AD surge como um campo de conhecimento que se desenvolve na França, entre as décadas de 1960 e 1970, tomando como referência e tentando levar a linguística herrisiana até as últimas consequências (PÊCHEUX et al, 1990, p.255). Já em 1952, no trabalho "Discourse Analysis: a sample text", o lingüista americano Z. S. Harris, retomado por Mazière (2007, p.7), definia a Análise de Discurso como dando conta - contrariamente à lingüística descritiva preocupada com os elementos da frase - de "uma multiplicidade de ensinamentos sobre a estrutura de um texto ou de um tipo de texto, ou sobre o papel de cada elemento nessa estrutura."

Não concebendo esses ensinamentos como estanques, representa a $\mathrm{AD}$ de orientação francesa um processo, isto é, "mais um movimento crítico que uma escola fornecendo categorias operatórias e métodos a aplicar." (MAZIÈRE, 2007, p.95) Dessa forma, constitui um método de compreensão de uma multiplicidade de objetos, segundo o qual não se trabalha a linguagem enquanto dado, mas como fato, tendo a sua origem vinculada ao político, o que a torna ponto de partida para compreendermos as formas textuais de sua representação. Em suas origens, portanto, a AD deriva da incorporação de métodos lingüísticos americanos aos estudos lexicais sociopolíticos na França que dá ensejo ao desenvolvimento de uma análise de natureza sociolingüística.

Antes de dispensar atenção ao "discurso comum e de todas as heterogeneidades" (MAZIÈRE, 2007, p.30), a $\mathrm{AD}$ privilegia os textos políticos escritos, mantendo uma relação intrínseca que acaba estabelecendo uma nova 
compreensão do político e, ao deslocar o lingüístico para assumir um caráter histórico, constrói para si "um lugar particular entre a disciplina lingüística e as ciências das formações sociais" (ORLANDI, 1990, p.25). Em uma interlocução com Courtine (1986), retoma Orlandi (1990, p.31) a história da $\mathrm{AD}$ como um movimento marcado por diferenças e rupturas com "políticas de esquerdas" nos anos 1960 e 1970, na "relação direta dos intelectuais com a política", "entre a prática política e o trabalho teórico". Nesse ínterim, acontece um distanciamento, caracterizado pelo silêncio, a indiferença e o individualismo dos intelectuais que levam ao refluxo e ao próprio vazio político.

Esse distanciamento implica a renovação do positivismo, transformando-se a $\mathrm{AD}$ em "uma prática dividida entre uma função crítica e uma função instrumental". (ORLANDI, 1990, p.31) Em sua função crítica, interroga a própria existência das disciplinas, desterritorializando-as. Mas, ao tempo em que o faz, constrói seus procedimentos, delimita seu objeto e tende, ela mesma, a se territorializar. Nesse processo de territorialização e desterritorialização, a $\mathrm{AD}$ percorre vários continentes. Tendo nascido na Europa, migra para a Grã-Bretanha e os Estados Unidos e se reterritorializa em muitos países da América Latina, inclusive, no Brasil.

Segundo Orlandi (2003, p.1), poderíamos até falar em uma Análise de Discurso francesa, inglesa, americana, brasileira etc., à medida que consideramos a $\mathrm{AD}$ como sendo desenvolvida nesses diversos contextos, "com suas diferentes tradições de estudos e pesquisas sobre o discurso." Na França, especificamente, onde Michel Pêcheux ocupou um lugar privilegiado nos trabalhos de produção do discurso, a AD é concebida como um dispositivo que coloca numa relação complexa o campo da língua 
e o campo da sociedade. Desterritorializando-se, a $\mathrm{AD}$ deixa de se concentrar exclusivamente sobre o discurso político para dirigir sua atenção, também, ao discursivo no campo jornalístico, pedagógico e tantos outros. O redimensionamento do seu território aponta na direção de uma nova concepção discursiva e procedimentos analíticos específicos.

Neste estudo, ao tentarmo-nos (re)aproximar do político, talvez nosso principal desafio seja efetuar uma análise crítica, evitando recorrer a um modelo instrumental. Notadamente porque nos defrontamos com o princípio de que, em $\mathrm{AD}$, tanto o discurso como o sujeito do discurso não constituem "los objetos dados a priori, sino los objetos a construir" (COURTINE, 1981). O fenômeno de investigação, portanto, não pré-existe ao corpus, mas em geral é justamente este que define o primeiro.

Recorremos à $\mathrm{AD}$, contudo, em busca de um aporte teórico-metodológico que pudesse nos ajudar a dimensionar o potencial da manifestação do discurso da industrialização do ensino na política nacional de educação a distância. Adotamos aqui, em particular, a Análise de Discurso de orientação francesa por ser concebida, logo em sua origem, como abordagem capaz de relacionar de forma complexa "o campo da língua (suscetível de ser estudada pela lingüística em sua forma plena) e o campo da sociedade apreendida pela história (nos termos das relações de força e de dominação ideológica)." (GADET, 1990, p.8)

Conforme reconhece Mazière (2007), sobretudo nas últimas três décadas, a $\mathrm{AD}$ encontra na América Latina, e no Brasil de modo especial, lastro para a continuidade de suas referências teóricas, através de estudos e pesquisas que reafirmam sua importância, a despeito de seu 
declínio na própria França, de suas variações e, às vezes até, do emprego "abusivo" do termo escola para nomear sua região de origem. De fato, esclarece Gregolin (2006), são fortes as filiações da $\mathrm{AD}$ brasileira com a mesma base conceitual francesa, mantendo uma tendência a se consolidar como campo fértil e trilhar uma fase avançada no Brasil. Dificulta isso a defasagem em relação à trajetória da AD na França que acabou legando problemas caros aos estudos brasileiros.

Mesmo considerando tais problemas, a hipótese de Gregolin (2006, p.24) é que os estudos recentes desenvolvidos no Brasil estariam "muito próximos" das idéias da AD francesa nos inícios dos anos 1980, quando entra na sua terceira fase. Marcada, principalmente, pelas preocupações de Pêcheux que desloca sua ênfase da formação discursiva para a idéia de "memória discursiva", "interdiscursividade", enfim, "heterogeneidade do discurso". $\mathrm{Na}$ contramão da $\mathrm{AD}$ francesa das últimas décadas, concentrada essencialmente nos fenômenos de natureza lingüística, retórica, pragmática ou interativo-conversacional, observamos no Brasil uma tendência a preservar a dimensão histórica ou político-epistemológica dos discursos (PIOVEZANI FILHO, 2006, p.246).

Seguimos neste estudo a tendência da AD desenvolvida no Brasil, com a pretensão de submeter o discurso em torno da política nacional de educação a distância as suas condições de produção não apenas discursivas, como também extra-discursivas. Engendradas, portanto, nas práticas sociais e discursivas que mobilizam, histórica e continuamente, formações sociais e ideológicas, com as quais a formação discursiva (FD) estabelece relações de interdependência. Daí a necessidade de recorrermos, por um lado, às contribuições de autores de orientação 
marxista, a destacar Bakthin e Pêcheux que nos ajudam a não perder de vista a influência das formações sociais sobre o discurso; e, por outro, às contribuições de um autor como Foucault, cuja noção de formação discursiva e da autonomia do discurso influencia substancialmente as idéias de Pêcheux e da AD francesa.

Além disso, mobilizaremos algumas das contribuições de Patrick Charaudeau para tratarmos, especificamente, do discurso político. Embora Charaudeau se acoste numa linha de pensamento que se orienta pelo viés de uma Teoria Semiolinguística, o autor nos legou recentemente dois estudos que não poderiam deixar de figurar entre nossas referências - "Discurso político" (CHARAUDEAU, 2006) e "Dicionário de análise do discurso", este último em co-autoria com Dominique Maingueneau, um dos principais nomes da AD francesa (CHARAUDEAU; MAINGUENEAU, 2006). Acrescemos a isso o reconhecimento das metodologias contemporâneas em apontar a possibilidade de o pesquisador assumir a inscrição de múltiplos métodos na análise do fenômeno.

\section{MAPA EPISTEMOLÓGICO DA AD}

A Análise de Discurso ${ }^{7}$ inscreve-se numa conjuntura dominada pela invenção do estruturalismo. Segundo Dosse (2007, p.11), o estruturalismo deve ser compreendido como "um movimento de pensamento, uma nova forma de relação com o mundo, muito mais amplo do

7 “O sintagma 'análise do discurso' rapidamente se transformou em 'análise de discurso', permitindo a análise 'dos' discursos, percebidos, por causa do plural, como tipos de discurso." (MAZIÈRE, 2007, p.25) 
que um simples método específico para um determinado campo de pesquisa", que obteve a adesão de grande parte da "intelligentsia", espalhando seus efeitos em inúmeros campos de aplicação das ciências humanas.

O estruturalismo germina no solo francês nos anos 1950, com a pretensão de se constituir "um único e vasto programa de análise" (Michel Serres), colocando-se como "a consciência despertada e inquieta do saber moderno" (Michel Foucault), "a aventura do olhar" (Jacques Derrida) e "a passagem da consciência simbólica para a consciência paradigmática" (Roland Barthes). Sua fonte de inspiração inicial é a lingüística, na versão de Roman Jakobson, que postula que o objetivo das ciências humanas é estudar os sistemas formais. Nessa compreensão, "um signo não tira sua significação de sua relação com o objeto que ele representa, mas de sua oposição com outros signos. Uma língua seria um sistema fechado de significações" (DOSSE, 2007, p.12).

Ao se reterritorializar para outras disciplinas, esse programa colocará em primeiro lugar "o estudo das formas e das relações, excluindo o das substâncias e das qualidades: oposições binárias em Claude Lévi-Strauss, quadro semiótico em Algirdes Julien Greimas, jogos de língua em Jacques Lacan". Idéia também fundamental, de procedência saussuriana, colocará a língua como um sistema preexistente ao uso que dela fazemos e a fala que produzimos, ao utilizar essa língua como representando, exclusivamente, "relações particulares e históricas". Ferdinand de Saussure discorrerá que "a língua é um fenômeno social cujas regras se constituem em plena revelia do sujeito que delas faz uso" (DOSSE, 2007, p.12). No fundo, a lente dosseniana considera o estruturalismo como filosofia para a qual convergem três ciências que atribuem ao 
inconsciente o lugar da verdade: a lingüística, a antropologia e a psicanálise.

Com efeito, marca o surgimento da Análise de Discurso o estabelecimento de uma ruptura com duas posturas teóricas dentro do domínio da linguagem - o estruturalismo (Saussure) e a gramática gerativa - e a sua constituição sob a referência da epistemologia althusseriana. Transformando a lingüística em ciência-piloto, o estruturalismo tentou definir seus métodos a partir da linguagem, estendendo pressupostos linguísticos a quase todas as áreas das ciências humanas e sociais, sem passar por reformulações profundas (HENRY, 1990, p.27). Razão pela qual as referências teóricas que dão origem à AD são encontradas no estruturalismo filosófico dos anos 1960, sobretudo, na sua leitura dos discursos ideológicos, o que vai se refletir, em particular, na rejeição por parte da $\mathrm{AD}$ de "qualquer metalíngua universal supostamente inscrita no inatismo do espírito humano, e toda suposição de um sujeito intencional como origem enunciadora de seu discurso." (PÊCHEUX, 1990a, p.311)

Em sua constituição como campo teórico, que se baseia na reflexão crítica com a finalidade de desvelar os determinantes ideológicos dos fatos ou eventos, a AD acaba articulando três regiões do conhecimento, traçando uma epistemologia que se movimenta no território da formação social, da ideologia, da língua e do discurso, tendo como pressupostos: 1) o materialismo histórico, como teoria das formações sociais e suas transformações; 2) a lingüística, como teoria dos mecanismos sintáticos e dos processos de enunciação; e 3) a teoria do discurso, como teoria da determinação histórica dos processos semânticos (PÊCHÊUX; FUCHS, 1990, p.163-164). Em que a semântica discursiva, como análise dos processos característicos 
de uma FD, deve dar conta da articulação entre o processo de produção de um discurso e as condições em que ele é produzido.

No que diz respeito ao materialismo histórico, a preocupação central de Pêcheux em vincular o discurso à prática política motiva uma opção clara em relação à concepção do sujeito althusseriano que se coloca entre o "sujeito da linguagem" e o "sujeito da ideologia" (HENRY, 1990, p.34). Como explicam Pêcheux e Fuchs (1990, p.165), a região que mais interessa a $\mathrm{AD}$ "é a da superestrutra ideológica em sua ligação com o modo de produção que domina a formação social considerada." Não se reduzindo apenas à expressão da base econômica, a ideologia constitui uma materialidade específica, cujo funcionamento é determinado pela esfera da economia, representando uma das condições da reprodução das relações de produção aí envolvidas. Marca esse funcionamento o processo de interpelação ou de assujeitamento, a partir do qual cada indivíduo - e, por extensão, cada classe ou fração de classe - ocupa um lugar específico no modo de produção.

A reprodução contínua dessas relações de classe dá-se, sobretudo, no contexto dos aparelhos ideológicos de Estado (AIE), onde as posições de sujeito vão constituir formações ideológicas que estabelecem entre si processos de dominação, aliança ou antagonismo. Refletindo essa interrelação numa esfera particular, as formações ideológicas encerram como um dos componentes importantes de sua materialidade as formações discursivas que determinam o funcionamento do discurso numa determinada conjuntura de um AIE e da relação de classes. Decorre daí que o sentido de um discurso só pode ser entendido como pertencente a uma dada FD, determinado isto por um processo que deve estabelecer as relações de paráfrases entre 
seqüências discursivas que, por sua vez, vão constituir a matriz do sentido inerente a essa formação. Produzindo o efeito de assujeitamento no discurso, é o fato justamente de toda seqüência necessitar pertencer a uma FD para adquirir sentido "que se acha recalcado para o (ou pelo?) sujeito e recoberto para este último, pela ilusão de estar na 'fonte do sentido', sob a forma da retomada pelo sujeito de um sentido universal preexistente" (PECCHEUX; FUCHS, 1990, p.169). Não é sem razão que, desde o início, a AD vai se afastar da idéia de análise semântica, pura e simplesmente, de um texto individual.

No que se refere à lingüística, outra região do conhecimento articulada pela $\mathrm{AD}$, sua importância se deve ao fato de constituir uma primeira fase da análise "absolutamente indispensável (não poderia haver aí análise sem uma teoria e uma prática linguísticas), mas insuficiente como tal, na medida em que ela existe com vistas a uma segunda fase" (PÊCHEUX; FUCHS, 1990, p.169). Donde decorre que o reconhecimento da Análise de Discurso como objeto comum de interesse acontece, ao mesmo tempo, em que se buscam métodos de análise lingüística, com uma preocupação de inspiração marxista em relacionar língua e classe social: " para trabalhar com a categoria de discurso, é necessário ser lingüista e deixar de sê-lo ao mesmo tempo." (COURTINE, 1999, p.18)

Numa época marcada por pouco interesse pela obra de Saussurre, Pêcheux revela-se um leitor atento daquele que institui o traço fundamental da lingüística moderna, ao conceber a língua como sistema (GADET et al, 1990, p.42). Provocando um deslocamento conceitual, Saussurre concebe a língua como objeto científico homogêneo, inscrito na região do semiológico e que se estabelece teoricamente sobre duas exclusões importantes: exclui a fala como 
sendo inacessível à lingüística; e exclui as instituições "não-semiológicas" (instituições políticas, jurídicas etc.) da região de interesse dessa ciência (PÊCHEUX, 1990b, p.71).

Apesar de pensar a língua em seu estatuto interno, Saussure reconhece que "é o ponto de vista que cria o objeto", abrindo caminho para se conceber a linguagem a partir de outras perspectivas que não exclusivamente lingüísticas. “O ponto de vista discursivo será um deles, o qual irá recuperar a noção de exterioridade, trazendo-a para dentro da língua, como parte integrante e constitutiva." (FERREIRA, 1999, p.61) Apoiando-se na gramática gerativa de Chomsky, principalmente na oposição estrutura de superfície-estrutura profunda, Pêcheux propõe então a relação entre estruturas discursivas de superfície e aquela que as determina, isto é, a "estrutura invisível".

Dos "Essais de linguistique générale" de Jakobson, Pêcheux (1990b, p.100) extrai proposições importantes para fazer avançar a linguística, enquanto se apóia em Benveniste para elevar a frase à condição de "enunciado", transformado em unidade do discurso, algo que não se reduz à ordem da gramática. No entanto, explica Gadet et al (1990, p.44), é Harris em particular que vai inspirar não só alguns procedimentos de análise, bem como todo o método de Análise Automática do Discurso (AAD), proposto por Pêcheux em 1969, em boa parte, como alternativa crítica à Análise de Conteúdo (NOTAS, 1990, p.153). Nesse sentido, vai perseguir a AD uma luta contra a visão idealista da língua, como percepção ou mesmo origem do mundo, sem reduzi-la à base de um léxico nem de sistemas fonológicos, morfológicos ou sintáticos. A AD concebe a língua como constituindo o lugar material onde se realizam os efeitos de sentido produzidos pelos processos 
discursivos, materialidade esta que enfatiza a idéia de funcionamento de Saussurre, em lugar da idéia de função (PÊCHEUX; FUCHS, 1990, p.179).

Relativamente à teoria do discurso, a terceira região do conhecimento que influencia a $\mathrm{AD}$, devemos ressaltar que Pêcheux acaba criticando sua própria pretensão em tentar formular uma teoria discursiva (MAZIĖRE, 2007, p.11). De todo modo, preocupa o autor questionar os esquemas propostos pelas teorias do comportamento (estímulo-resposta) e da informação (emissor-mensagem-receptor), concebendo o discurso como um "efeito de sentidos" entre interlocutores e não simplesmente como transmissão de informação de um sujeito a outro. Isso implica considerar que um discurso é sempre evocado, a partir de condições de produção determinadas ou representadas na estrutura de uma formação social, além de ser remetido às relações em que é produzido, uma vez que todo discurso remete a um outro: "o objeto de uma sociologia do discurso seria, pois, o de verificar a ligação entre as relações de força (exteriores à situação do discurso) e as relações de sentido que se manifestam nessa situação" (PÊCHEUX, 1990b, p.87).

Nessa perspectiva, a AD trava uma luta contra a tendência das teorias da enunciação, representadas por Benveniste, em reproduzir a ilusão de um sujeito enunciador, portador de intenções, escolhas e decisões. Herdeiras de uma "lingüística da fala", ao conceber o sujeito como origem e operador de seu discurso, essas concepções asseguram a passagem da língua à ordem do discurso, impedindo "que se pense a especificidade do discurso e a questão do assujeitamento, rebaixando-os a uma problemática instrumental da língua em uso." (COURTINE, 1999, p.17). Contrariamente a isso, os processos de enunciação compreendem determinações sucessivas que colocam fronteiras entre o que é selecionado ou dito e o que 
é rejeitado ou não dito pelo sujeito. $\mathrm{O}$ exame das marcas ligadas à enunciação passa a ser essencial à fase de análise lingüística da $\mathrm{AD}$, sugerindo mudanças nas concepções relativas à língua, mormente no que respeita ao léxico e à sintaxe. Na verdade, não é da língua em si ou da materialidade da língua que se pretende tratar, porém do próprio domínio do discurso.

O mapa epistemológico da $\mathrm{AD}$, enfim, é atravessado e articulado por uma teoria da subjetividade de cunho psicanalítico (PÊCHEUX, FUCHS, 1990, p.164) que precede a região do materialismo histórico. Resquício de um distanciamento entre este e a psicanálise, temos a proposição de uma teoria não-subjetiva do uso da linguagem, cuja ênfase reside no fato de que, embora fundamental (não pode haver discurso sem sujeito), a noção de sujeito é descentrada e integrada ao funcionamento dos enunciados, uma vez que o sujeito é constituído socialmente. Não são, portanto, as intenções individuais, mas as convenções articuladas em formações ideológicas que vão constituir o discurso (ORLANDI, 1988, p.10).

Em consequência desse descentramento, a AD francesa vai se apresentar em três momentos, ao longo de sua trajetória até os anos 1980. Caracteriza o primeiro momento, reconhece o próprio Pêcheux (1990a, p.311), um processo de produção do discurso, concebido como uma máquina discursiva "fechada sobre si mesma, de tal modo que um sujeito-estrutura determina os sujeitos como produtores de seus discursos: os sujeitos acreditam que 'utilizam' seus discursos quando na verdade são seus 'servos' assujeitados, seus 'suportes'." Essa noção de maquinaria discursiva de inspiração estrutural é colocada em questão no segundo momento da $\mathrm{AD}$, a partir do instante em que esta insiste na alteridade da identidade discursiva do sujeito. 
A tentativa de instaurar uma nova fase de análise lingüístico-discursiva conduz a $\mathrm{AD}$ a seu terceiro momento, caracterizado por uma maior atenção à heterogeneidade enunciativa e, em particular, ao discurso-outro, concebido sob duas perspectivas: um discurso tomado de empréstimo a outro sujeito; e um interdiscurso que se encontra acima do controle do sujeito enunciador, seja para estruturar estrategicamente seja para desestabilizar o discurso (PÊCHEUX, 1990a, p.317). Além da revisão de conceitos fundamentais, caracteriza essa fase a busca de novos objetos, corpus, métodos e procedimentos de análise que objetivam traduzir a heterogeneidade do sujeito e do discurso, notadamente, em meio a um cenário em que o marxismo e o socialismo são revistos, emerge o processo de globalização da economia e se intensifica a expansão das tecnologias de informação e comunicação (GREGOLIN, 2006, p.20).

Esse amadurecimento da AD implica como um de seus principais resultados a ampliação da compreensão acerca de seu objeto. O discurso passa a ser concebido, segundo Pêcheux (1990c), tanto como estrutura quanto como acontecimento. Estrutura, porque emerge como organização dos dizeres; acontecimento, porque pode essa mesma estrutura ser reorganizada ou reestruturada por força do enunciado, um acontecimento discursivo por natureza. Propondo um novo aporte teórico para a ideologia, o método de Pêcheux se baseia na compreensão das formas materiais da linguagem. "A materialidade específica da ideologia é o discurso e a materialidade específica deste é a língua. O discurso é assim o observatório da relação língua/ideologia." (ORLANDI, 2005)

Sendo assim, acentua Orlandi (2002), a língua assume a condição de possibilidade da emergência do discurso. Diferentemente das noções mecanicistas de informação 
e de mensagem, o discurso é "efeito de sentidos" entre sujeitos que estabelecem uma relação de (contra)argumentação, subjetivação e construção da realidade. Se quisermos determinar a regularidade e o funcionamento do discurso, não devemos opor o produto ao processo discursivo, o sistema à realização do acontecimento ou o social ao histórico. Mais precisamente, Maingueneau (2002) entende o discurso como uma organização que transcende a frase, sendo ele orientado, interativo, contextualizado, assumido por um sujeito, regido por normas e situado no bojo de um interdiscurso. Além disso, não se resume o discurso a uma representação acerca do mundo, mas constitui uma ação sobre este e sobre o outro capaz de relacionar a atividade verbal a atividades não-discursivas.

\section{OBJETO TEÓRICO E OBJETO EMPÍRICO: uma questão de método}

As múltiplas perspectivas de análise utilizadas para observar um fenômeno produzem, segundo Orlandi (1993a, p.15), diferentes objetos de conhecimento, com características próprias e distintas "entre o objeto empírico e o objeto científico que é construído." Diferentemente da lingüística tradicional, a Análise de Discurso não trabalha simplesmente o produto, mas os processos de constituição do fenômeno lingüístico que representam seu recorte teórico fundamental. Para os objetivos da AD, torna-se imperioso que a linguagem seja demarcada pelo seu caráter social, representando o discurso - ainda que sua materialidade, em princípio, seja lingüística - um objeto sócio-histórico, onde o "lingüístico intervém como pressuposto." (PÊCHEUX; FUCHS, 1990, p.188) 
$\mathrm{O}$ mérito da $\mathrm{AD}$, por isso mesmo, repousa sobre o fato de se constituir no lugar em que a linguagem deve se reportar à exterioridade, sobretudo, no sentido de que seu processo significativo seja devidamente determinado. $\mathrm{Na} A D$, não se descreve a função, mas o funcionamento que permite sistematizar, reconhecer regularidades, compreender o discurso como fazendo parte do histórico, do social (ORLANDI, 1996a, p.23). Neste sentido, a AD redefine o lugar do sujeito e a situação de enunciação. Além de conceber esta em sua ordem própria, ao invés de pensar o sujeito como tendo o controle, ou mesmo, identificando-se com o sistema, a AD leva em conta a relação contraditória que o sujeito estabelece com essa estrutura (ORLANDI, 1996b, p.26).

A AD entende a linguagem como trabalho, transformação, produção e interação que se define como uma relação necessária entre homem, realidade natural e social, pois nenhuma linguagem pode se separar da sociedade que a produz. Quando transcende a função referencial da palavra, a AD concebe esta como um "ato social com todas as suas implicações: conflitos, reconhecimentos, relações de poder, constituição de identidades etc." (ORLANDI, 1993a, p.17) Com isso, elimina-se o percurso apenas pelo psíquico ou social, atravessando também o domínio da ideologia. Dessa forma, os interlocutores, a situação, o contexto sócio-histórico, ideológico, ou seja, as condições de produção constituem o sentido da sequiência verbal produzida.

Todo sujeito ocupa um lugar na sociedade e isso faz parte das relações de força no discurso, do que decorre que o princípio fundamental da $\mathrm{AD}$ é considerar que a relação entre a linguagem e a exterioridade é constitutiva e o processo de significação, por natureza, é histórico. Nessas 
condições, o sujeito não se apropria da linguagem individualmente, porque essa ação é social, o que revela o modo como o sujeito o fez, como a ideologia o interpelou. A preocupação da $\mathrm{AD}$ não é realizar isoladamente a análise lingüística do texto nem sociológica ou psicológica do seu contexto, mas sobretudo relacionar a sua enunciação a um lugar social específico e determinado (MAINGUENEAU, 1997, p.13-14).

Não há problemas em reconhecermos que os discursos são feitos de signos, desde que estes sejam concebidos como designando muito mais do que apenas as coisas. Mesmo compreendido como um grupo de enunciados (compostos de signos) que se apóiam numa mesma formação discursiva, para os quais é possível definir uma regularidade ou "o conjunto das condições nas quais se exerce a função enunciativa que assegura e define sua existência" (FOUCAULT, 2002, p.165), o discurso pertence, acima de tudo, ao campo da ideologia. Significa que as formações ideológicas comportam, entre seus elementos, uma ou mais formações discursivas que determinam o que deve e pode ser dito numa determinada conjuntura, "isto é, numa certa relação de lugares no interior de um aparelho ideológico, e inscrita numa relação de classes." (PÊCHEUX; FUCHS, 1990, p.166-167)

Conforme Maingueneau (1997, p.50), na acepção de Foucault a FD diz respeito a um conjunto de enunciados que seguem o mesmo sistema de regras, transcendendo unidades tradicionais como ciência e ideologia; enquanto para Pêcheux, designa o fato de que toda e qualquer formação social encerra posições político-ideológicas não originadas nos indivíduos, mas em formações que mantêm relações complementares ou antagônicas. Segundo o próprio Pêcheux (1988, p.254), o emprego do materialismo 
histórico não se reduz à simples referência às condições de produção sócio-históricas do discurso. Precisamos explicitar, ainda, o conjunto complexo, desigual e contraditório das formações discursivas em jogo numa situação dada, sob a dominação do conjunto das formações ideológicas, tal como a luta ideológica das classes determina.

Uma FD, em princípio, estrutura-se e se impõe de forma hierárquica a todo e qualquer sujeito, através de "enunciados retores" que demarcam o campo dos objetos possíveis e os limites entre o enunciável e o não enunciável (LECOURT, 1971, p.57). Contudo, ela não se estabelece unicamente nem se configura de forma homogênea. Seguindo a noção de Foucault, Pêcheux (1990a, p.314) esclarece que uma dada formação é normalmente invadida por elementos de outras formações discursivas "que se repetem nela, fornecendo-lhe suas evidências discursivas fundamentais (por exemplo sob a forma de 'preconstruídos' e de 'discursos transversos')."

Ao invés de constituir um bloco compacto que se contraporia a outros discursos, a FD é perpassada por uma interdiscursividade que a torna heterogênea por excelência, até porque carrega uma memória discursiva cujas formulações repercutem, recusam e transformam outras tantas formulações (MAINGUENEAU, 1993, p.115). Trata essa memória ou interdiscurso do conjunto de processos discursivos que ajudam a delimitar a atuação das diferentes formações discursivas sobre um discurso. A FD acaba se constituindo, em conseqüência, na relação que estabelece com essa memória do dizer, manifestando no interior deste as formações ideológicas.

Constitui o interdiscurso, por isso mesmo, o espaço ideológico-discursivo através do qual as formações discursivas estabelecem relações de dominação, subordinação e 
contradição. Mediante o interdiscurso, uma FD absorve elementos pré-construídos em outras formações, os quais são correlacionados aos seus "por efeitos-transversos que os incorporam, na evidência de um novo sentido em que eles são 'acolhidos' e fundados" (PÊCHEUX, 1988, p.278). Tanto as anterioridades como as heterogeneidades do interdiscurso não constituem exatamente o contexto, porém encontram-se inscritas "no próprio interior do intradiscurso" (MAZIÈRE, 2007, p.62). Como o interdiscurso encontra-se simulado no intradiscurso, só se tem acesso as suas condições de produção, historicidade ou circunstâncias de enunciação. A constituição do sentido, no entanto, se dá na relação com o interdiscurso, uma trama de sentidos cuja instância de formulação (o intradiscurso) passa pela materialidade do discurso, pela ideologia.

Na realidade, não há discurso que não estabeleça relação com outros, formando uma intricada discursividade, a ponto de um único texto refletir a presença de várias formações que, contraditoriamente, nele se organizam, tendo em vista uma formação dominante (ORLANDI, 2002, p.70). Desse modo, considerando que os indivíduos são interpelados em sujeitos-falantes ou sujeitos de seu discurso por formações discursivas determinadas que, por sua vez, representam na linguagem as respectivas formações ideológicas, concebemos a FD como "aquilo que, numa formação ideológica dada, isto é, a partir de uma posição dada numa conjuntura dada, determinada pelo estado da luta de classes, determina o que pode e deve ser dito" (PÊCHEUX, 1988, p.160-161).

Os objetos que interessam precipuamente à $\mathrm{AD}$ correspondem, por conseguinte, a formações discursivas (MAINGUENEAU, 1993, p.14), donde decorre que as palavras não existem nem guardam um sentido que lhes 
sejam próprios ou intrínsecos a sua possível literalidade. Na realidade, elas adquirem sentido em referência às posições e formações ideológicas nas quais acabam sendo produzidas ou reproduzidas. Mais precisamente, seu sentido se constitui em cada FD que representa o lugar ou matriz dessa constituição, estabelecida através das relações que tais elementos mantêm com outros da mesma formação, o que explica o fato de que, ao passar de uma FD a outra, as palavras acabam mudando seu sentido.

\section{A construção do corpus discursivo}

A relação entre o objeto teórico e o de análise refere a relação estabelecida entre o discurso e o texto. "O objeto teórico é o discurso e o objeto empírico (analítico) é o texto" (ORLANDI, 1996a, p.21). Entendemos o corpus discursivo, por essa razão, como um conjunto de textos estruturados na forma de superfícies lingüísticas que se encontram dominados por condições de produção consideradas estáveis e homogêneas: "um conjunto de imagens textuais ligadas a um 'texto' virtual (isto é, ao processo discursivo que domina e engendra as diferentes seqüências discursivas pertencentes ao corpus)." (PÊCHEUX; FUCHS, 1990, p.239)

Se tais condições devem se apresentar estáveis, o mesmo não ocorre ao próprio corpus que não se trata de um aglomerado estanque de textos, mas um conjunto "sem fronteira", no qual a exterioridade do discurso - o interdiscurso - acaba emergindo no intradiscurso (MAZIÈRE, 2007, p.61). Decorrendo de condições sócio-históricas determinantes à análise lingüística, a constituição do corpus objetiva delimitar e construir os dados e uma teoria relativamente ao exterior do discurso, contribuindo 
para encetar uma perspectiva heurística, um ponto de vista sobre os dados discursivos (CHARAUDEAU; MAINGUENEAU, 2006, p.139).

Considerando que a EAD não pode ser tratada como ciência nem teoria e que a análise das práticas discursivas encontra seu ponto de equilíbrio no saber, em especial, na formação e transformação de um saber, contido não apenas no conhecimento científico como "também em ficções, reflexões, narrativas, regulamentos institucionais, decisões políticas" (FOUCAULT, 2002, p.208), nosso corpus discursivo faz parte de um vasto arquivo, constituído pelos discursos em torno da política de educação a distância no Brasil. Não se confundindo com a noção genérica de registro e preservação de documentos (SARGENTINI, 2006, p.35), o arquivo é concebido como o conjunto de todos os enunciados efetivamente produzidos que circulam em um dado momento histórico (GREGOLIN, 2006, p.27).

Conforme Revel (2005, p.19), a noção de arquivo formulada por Foucault permite a este autor distinguir-se tanto dos estruturalistas, ao considerar o discurso como acontecimento e não sob o ponto de vista do sistema da língua, como também dos historiadores, ao partir do princípio de que os acontecimentos transcendem o presente. Numa acepção foucaultiana, o arquivo não diz respeito à soma dos textos, dos documentos do passado, dos testemunhos da identidade de uma cultura, nem tampouco às instituições encarregadas do registro e conservação dos discursos. Constitui o arquivo as regras de uma prática que rege a emergência dos enunciados como acontecimentos discursivos singulares que subsistem e se modificam regularmente, referindo o sistema geral de discursividade ou de formação e transformação do discurso. 
O arquivo, também, é aquilo que faz com que as palavras e as coisas ditas se agrupem e reagrupem, transitem entre tradição e esquecimento e se atualizem ou desapareçam como enunciados. A revelação, jamais alcançada, do arquivo de uma época, cultura ou sociedade forma, enfim, "o horizonte geral a que pertencem a descrição das formações discursivas, a análise das positividades, a demarcação do campo enunciativo." (FOUCAULT, 2002, p.151) Atualizando essa discussão à emergência dos "bancos de dados", Pêcheux (1997) por sua vez parte da idéia de arquivo em duas vertentes: como campo dos documentos disponíveis e referentes a uma determinada questão; e como instância de gestão administrativa dos documentos, com fins estatais ou comerciais, objetivando facilitar sua comunicação, transmissão e reprodução .

Como resultado do trabalho dos aparelhos de Estado em gerir a "memória coletiva", o emprego crescente do arquivo pelos cientistas acabou contribuindo para o desenvolvimento da informática e de diferentes métodos de análise textual, incluindo a Análise de Conteúdo.

8 Do modo como são concebidos e organizados, os arquivos que pesquisamos se reportam em geral a essa idéia tradicional e instrumental de "arquivo": do grego arkheia, significa documentos do governo; do latim archívum, lugar onde se guardam os documentos. O "Dicionário brasileiro de terminologia arquivística", edição de 2005, oferece quatro definições para arquivo, em sua acepção mais geral: "1 Conjunto de documentos produzidos e acumulados por uma entidade coletiva, pública ou privada, pessoa ou família, no desempenho de suas atividades, independentemente da natureza do suporte. 2 Instituição ou serviço que tem por finalidade a custódia, o processamento técnico, a conservação e o acesso a documentos. 3 Instalações onde funcionam arquivos. 4 Móvel destinado à guarda de documentos." (DICIONÁRIO, 2005, p.27) 
Do ponto de vista de uma concepção discursiva, adverte Pêcheux (1997, p.63), o que devemos enfatizar é a presença da "materialidade da língua na discursividade do arquivo", reconhecendo inclusive as preocupações de historiadores, lingüistas e outros analistas em focalizar "os interesses históricos, políticos e culturais", mediante as mais diversificadas leituras de arquivo.

Como o arquivo em questão, praticamente, é impossível de ser pesquisado no seu conjunto, nosso estudo buscou examinar, em especial, o discurso em torno da política nacional de EAD pronunciado pelo Governo Federal. O que implica, por um lado, contemplar desde os órgãos componentes do primeiro escalão de governo (presidência da República, Ministério da Educação etc.) até as empresas estatais, fundações, autarquias e universidades federais; e, por outro, excluir toda e qualquer instância que aí não se inclua, desde os governos estadual e municipal até as organizações não governamentais.

Direcionamos nossa pesquisa, portanto, para o âmbito macro da política de EAD que, por um lado, abrange todo um sistema federal de planejamento, organização e fomento e, por outro, exclui de sua responsabilidade imediata a execução das práticas de educação a distância no interior dos Estados, municípios e estabelecimentos de ensino. As funções atribuídas à Secretaria de Educação a Distância (SEED) ilustram bem isso, estando aquele órgão basicamente subdividido em três departamentos: Diretoria de Regulação e Supervisão em EAD, Diretoria de Infra-Estrutura em Tecnologia Educacional e Diretoria de Produção de Conteúdos e Formação em EAD. Organizada como uma estrutura complexa que representa o MEC na área de EAD, cabe à SEED, em especial, "formular, propor, planejar, avaliar e supervisionar políticas e programas de 
educação a distância, visando à universalização e democratização do acesso à informação, ao conhecimento e à educação, em todos os níveis e modalidades de ensino" (BRASIL, 2007c).

Entendemos que não constitui um erro utilizar as expressões discurso oficial, discurso governamental ou discurso político como equivalentes, reflexos ou derivações do discurso pronunciado pelo Governo Federal. Primeiro, porque o discurso oficial constitui em geral uma instância de enunciação com legitimidade institucional, portanto, competente e autorizada para representar e expressar o pensamento "oficial" de uma dada instituição. Segundo, porque o discurso governamental tende a constituir a instância de enunciação legítima, competente e autorizada de governo, diferenciada, por essa razão, da "fala" das organizações não governamentais e da sociedade civil como um todo. Nesse sentido, aproximando-nos do pensamento foucaultiano, Chaui (1981, p.7) ressalta que: "O discurso competente confunde-se, pois, com a linguagem institucionalmente permitida ou autorizada, isto é, com um discurso no qual os interlocutores já foram previamente reconhecidos como tendo o direito de falar e ouvir".

Em terceiro lugar, porque assume o discurso de Estado um sentido político, em princípio, como qualquer outro enunciado que a circunstância de enunciação o autorizar. "Não é, portanto, o discurso que é político, mas a situação de comunicação que assim o torna. Não é o conteúdo do discurso que assim o faz, mas é a situação que o politiza." (CHARAUDEAU, 2006, p.40) Mesmo considerando que os lugares de produção, difusão e circulação do discurso político são os mais diversos possíveis, não se reduzindo aos "responsáveis pela governança", torna-se forçoso 
observar que o discurso oficial ou governamental tende a se revestir no discurso político com maior regularidade, ou mesmo, por excelência.

Seguindo Charaudeau (2006, p.40), isso sugere que o discurso do Governo Federal em torno da política de EAD estaria inscrito em meio ou na transição entre o primeiro e o segundo dos três lugares de fabricação do discurso político, a saber, como sistema de pensamento, como ato de comunicação e como comentário. O discurso político como sistema de pensamento resulta de um processo discursivo que objetiva fundar um modelo importante à construção das opiniões e posicionamentos, portanto, às filiações ideológicas. O discurso político como ato de comunicação dedica-se a construir a imagem dos atores participantes da cena de comunicação e a usar estratégias retóricas de persuasão e sedução.

Levando em conta, por outro lado, a sua extensividade, nosso corpus discursivo remonta, praticamente, o conjunto das iniciativas do Estado brasileiro no campo da educação a distância. O que perfaz um período que compreende desde meados do século XX até os anos 2000, por ocasião do governo Lula. Justifica esse recorte amplo o fato de que o fenômeno a investigar - o discurso em torno da política nacional de EAD - não permite ser pensado de forma reducionista, visto que atravessa toda uma fase em que o país decide apostar em sua industrialização e modernização.

Como nos lembra Mazière (2007, p.35), há quatro décadas, Dubois já chamava atenção que "o corpus é uma escolha de difícil extração, dado que é tomado no 'universal do discurso'. Ele será representativo se for homogêneo no tempo e no espaço ('homogeneidade da situação de comunicação') e tradutor de uma ideologia". Levando em 
conta, ademais, que a $\mathrm{AD}$ em geral "não se ocupa de formações discursivas que estariam investidas em um único gênero" (MAINGUENEAU, 1993, p.37) nem que o discurso "se dá como algo discernido e posto" (ORLANDI, 2002, p.63), nosso corpus constitui-se, essencialmente, dos seguintes tipos de documentos e textos: projetos, planos, relatórios e publicações relativas às políticas, programas e ações do Governo Federal na área de educação a distância.

Considerando a diversidade de pontos de vista sobre a noção de gênero, que ora se apegam às características formais ou composicionais do texto, ora à natureza comunicacional ou ancoragem social do discurso, preferimos empregar o termo "tipo". Mais precisamente, tipo de discurso que reputa "uma definição ampla, que o faz designar não importa qual classe de discurso, qualquer que seja o critério que preside seu estabelecimento" (CHARAUDEAU; MAINGUENEAU, 2006, p.468). A expressão tende representar, com mais proximidade, a heterogeneidade do corpus em estudo, cuja especificidade repousa em configurar um discurso de ordem político-institucional ${ }^{9}$.

Os documentos e textos selecionados, por isso mesmo, cumprem um papel que vai além da forma de estatuto ou de registro escrito de como as diversas iniciativas político-institucionais vão forjando e legitimando um discurso

9 Discurso este inscrito, de forma mais ampla, entre os gêneros secundários do discurso que, segundo Bakhtin (1992, p. 281), "aparecem em circunstâncias de uma comunicação cultural, mais complexa e relativamente mais evoluída, principalmente escrita: artística, científica, sociopolítica. Durante o processo de sua formação, esses gêneros secundários absorvem e transmutam os gêneros primários (simples) de todas as espécies, que se constituíram em circunstâncias de uma comunicação verbal espontânea." 
e um ordenamento oficial de política de educação a distância. Por um lado, dado ao caráter plurissemiótico do texto, não há sentido em diferenciar automaticamente o discurso oral do corpus escrito (CHARAUDEAU; MAINGUENEAU, 2006, p.466), mesmo porque este último não representa meramente uma oralidade empobrecida. "Embora o texto seja escrito, ele é sustentado por uma voz específica: 'a oralidade não é o falado', como lembra H. Meschonnie" (MAINGUENEAU, 1993, p.46). Por outro lado, mesmo a enunciação monológica na forma imobilizada de um texto escrito, significa uma resposta ou continuidade a alguma coisa, representa um elemento da comunicação verbal, "um elo da cadeia dos atos de fala." (BAKHTIN, 1988, p.98)

\section{Universo e condições de produção da pesquisa}

Nosso corpus discursivo resulta de uma pesquisa de campo realizada, basicamente, através de dois tipos de levantamento - o primeiro in loco e, o segundo, online, efetuados junto aos arquivos impressos, digitais e eletrônicos de um conjunto de instituições públicas da esfera federal. A pesquisa in loco que empreendemos foi realizada na cidade de Brasília-DF, em setembro de 2006, envolvendo os arquivos de órgãos vinculados ao Ministério da Educação (a SEED e o Centro de Informação e Biblioteca em Educação-Cibec) e o acervo das bibliotecas e sistemas de informação do Senado, Câmara Federal e Universidade de Brasília (UnB).

Além do MEC e o Congresso Nacional representarem organismos com interferência direta sobre a política nacional de EAD, a escolha da Biblioteca Central (BCE) da UnB deveu-se ao fato daquela universidade constituir 
uma das maiores referências em EAD no país, principalmente, na área de formação continuada de professores. A UnB representa uma das quatro universidades brasileiras a manter Cátedra Unesco de Educação a Distância e, em 2006, foi a instituição que mais ofertou ensino a distância no Brasil, desenvolvendo dezenas de projetos, voltados sobretudo para o serviço público: "a proximidade com grandes estatais e com o núcleo político do país a torna mais sensível às agendas desses setores. Ela é procurada para ações corporativas de grande envergadura" (AS INSTITUIÇÕES, 2007, p.39).

Cabe a SEED, no atual governo Lula, planejar, coordenar e supervisionar em torno de duas dezenas de programas e projetos, distribuídos nas seguintes áreas: audiovisual (DVD Escola, Rádio Escola, TV Escola e Luz, Câmera, educAção); mídia digital (Portal Domínio Público, Webeduc, Proinfo, E-Proinfo, Rived e Seednet); ensino (E-Tec Brasil e UAB); pesquisa (Paped) e; formação e capacitação (Formação pela Escola, Mídias na Educação, Proformação e Salto para o Futuro). A simples discriminação dessas ações nos oferece uma idéia aproximada da importância da SEED, sobretudo, levando em conta que sua atuação ultrapassa mais de uma década. A Secretaria chega ao quarto governo, ao segundo presidente da República e a mais de um ministro de Estado, somando em seus quadros alguns secretários e uma série de coordenadores, chefes de departamento e especialistas que, de uma forma ou de outra, contribuíram para consolidar uma posição de instância discursiva privilegiada sobre a EAD no país.

O volume de documentos e textos sob a rubrica da Secretaria, por isso mesmo, não poderia ser ignorado, mesmo porque o leque de suas atribuições e ações 
ampliou-se consideravelmente com a própria modernização do Estado brasileiro, impondo maiores exigências não só em termos de planejamento e gestão, bem como de supervisão e avaliação dos programas. O que implica a elaboração permanente de diretrizes, projetos e relatórios, além da proposição de documentos legais e institucionais para cada programa criado e implementado. Contudo, o levantamento junto aos arquivos da SEED não correspondeu às nossas expectativas, resultando na coleta de alguns poucos relatórios e publicações recém editadas.

Acontece que, assim como ocorria aos demais órgãos ligados ao Ministério da Educação, boa parte do acervo da SEED estava em vias de digitalização, sob o poder do Cibec. Vinculado ao Instituto Nacional de Estudos e Pesquisas Educacionais Anísio Teixeira (Inep), o Centro é responsável pela disseminação de informações educacionais de natureza terciária, secundária (originárias de instituições educacionais públicas e privadas) e primária, produzidas pelo próprio Inep. Apesar de ter sido fundamental para reconhecermos, mais amplamente, o grande arquivo existente sobre a política de EAD que não se resume à atualidade, não foi possível efetuarmos um levantamento exaustivo, como demandava o Cibec. Por diversas vezes, o sistema de acesso ao seu catálogo online tornou-se indisponível. Além dos vários documentos em processo de digitalização, a reprodução de alguns textos também se mostrou restrita: "cópias só poderão ser providenciadas em conformidade com a Lei de Direitos Autorais vigente." (BRASIL, 2007b)

Essas limitações fizeram acentuar a importância de pesquisarmos outros acervos. De sorte que, paralelamente aos arquivos da SEED e do Cibec, conduzimos uma série de levantamentos nas bibliotecas e sistemas de informação 
da UnB, Câmara dos Deputados e Senado Federal. A nossa consulta ao catálogo da Rede Virtual de Bibliotecas Congresso Nacional (RVBI) foi importante, em particular, para vislumbrarmos a importância política atribuída pelo Poder Legislativo ao fenômeno da EAD. Mas, ao mesmo tempo em que constatávamos in loco a "riqueza" daqueles arquivos, problemas de ordem operacional acabaram limitando o levantamento junto aos mesmos. Um deles foi o horário de funcionamento para o usuário externo que se mostrou insuficiente para as pretensões da pesquisa e o outro derivou do fato de que uma série de documentos não pôde ser consultada, por ser de uso exclusivo dos servidores do Congresso (CÂMARA, 2007).

A nossa recorrência à Biblioteca Central da UnB acabou representando, finalmente, alternativa das mais proveitosas para os fins da pesquisa. $\mathrm{O}$ acesso irrestrito ao acervo da biblioteca nos foi crucial, principalmente, para o livre trânsito a uma série de textos e documentos. Graças à natureza, em certa medida, arqueológica da pesquisa, a própria "desatualização" do acervo da BCE tornou-se uma qualidade. A recuperação de uma série de publicações "antigas" ganhou enorme importância, à medida que assumiam elas, de modo especial, a condição de "fiéis depositárias" de traços discursivos que outros momentos sócio-históricos decidiram-lhes imprimir, evidenciado decisivamente que a regularidade do discurso da industrialização do ensino ultrapassava as fronteiras da política atual de EAD.

Mesmo considerando seu curto período de execução e algumas dificuldades enfrentadas, a pesquisa que realizamos em Brasília resultou na recuperação de um material de extrema relevância, parte em sua forma original e a maior parte na forma de cópia integral ou parcial. Trata-se 
de um conjunto de publicações relacionadas às iniciativas do Estado brasileiro no campo da educação a distância, produzidas, editadas, encomendadas ou patrocinadas pelo Ministério da Educação e outros órgãos ligados ao Governo Federal. O material compreende duas dezenas de documentos e textos que servem de base para constituirmos o nosso corpus discursivo.

Por outro lado, a pesquisa a distância que empreendemos, através de levantamento online, foi realizada ao longo de 2007, basicamente, junto a dois endereços eletrônicos de importância capital para dimensionarmos a política educativa brasileira e, em particular, a política de EAD - o Portal do Ministério da Educação (disponível em http:// portal.mec.gov.br) e o Portal Domínio Público (http://www.dominiopublico.gov.br). Apesar de se apresentar importante consultarmos páginas relacionadas aos links Ministério, Áreas, Programas, Sistemas, Autarquias e Serviços que dão a dimensão da estrutura complexa envolvendo o MEC e explicam representar sua home page uma das mais visitadas na internet brasileira (BRASIL, 2007a), seria impossível pesquisarmos o Portal MEC no seu conjunto.

Considerando que, no seu lançamento em novembro de 2004, o Portal MEC já continha "quase 38 mil páginas, entre conteúdo e arquivo" (BRASIL, 2004a), demos ênfase à página da Secretaria de Educação a Distância (http:// portal.mec.gov.br/seed), órgão diretamente responsável pela política e programas em EAD. A página da SEED nos foi de extrema relevância para levantarmos, consultarmos e recuperarmos informações e arquivos de natureza administrativa, político-institucional e legal. Encontramos ali disponibilizados, grosso modo, três tipos de dados: legislação, regulamentação e referenciais de qualidade 
para a EAD nacional; apresentação, estruturação, projetos e programas desenvolvidos pela Secretaria; e, por último, notícias produzidas pela Assessoria de Imprensa da SEED, publicadas na sua própria home page e através da Seednet, uma revista eletrônica (http://www.seednet. mec.gov.br).

Concentramos a pesquisa, todavia, junto aos links que remetiam aos diversos programas conduzidos pela SEED, uma vez que tendiam a expressar mais direta e explicitamente a orientação da política nacional de educação a distância. Parte deles oferecia poucos dados, resumidos em geral a informações sobre objetivos, organização, funcionamento e alcance. Caso dos programas DVD Escola, que não possuía home page, até porque configura uma extensão da TV Escola; Programa de Apoio à Pesquisa em Educação a Distância (Paped), cujo site encontrava-se desatualizado (http://paped.proinfo.mec.gov.br/); Luz, Câmera, EducAção, abrigado como um link na página da Seednet; e WebEduc, o Portal de Conteúdos Educacionais do MEC (http://webeduc.mec.gov.br/) que não disponibilizava informação própria, mas "material de pesquisa, objetos de aprendizagem e outros conteúdos educacionais de livre acesso", produzidos por instituições, portais nacionais e estrangeiros, além de programas da SEED/ MEC (BRASIL, 2007d).

Um dos programas disponibilizados pelo WebEduc tratava-se da Rede Interativa Virtual de Educação (Rived), em cuja home page (http://www.rived.mec.gov. $\mathrm{br} /$ ) encontramos notícias, artigos e, principalmente, conteúdos pedagógicos digitais na forma de objetos de aprendizagem. Além dos links localizados na própria página da SEED, assim como o Rived, outros programas dispunham de sua própria home page. Incluíam-se aí o FormAção 
pela Escola que mantinha o SIFE, um sistema de informação vinculado ao programa (http://sife.proinfo.mec. gov.br/principal/index.php); o Programa de Formação de Professores em Exercício (Proformação) que, além do seu Sistema de Informações (SipWeb), dispunha de site próprio (http://proformacao.proinfo.mec.gov.br/); e o e-ProInfo que, por natureza, já constituía um Ambiente Colaborativo de Aprendizagem a Distância (http:// www.eproinfo.mec.gov.br/).

O acesso ao programa FormAção pela Escola somente era permitido ao usuário cadastrado no SIFE e, em se tratando do Proformação e e-ProInfo, o visitante podia acessar basicamente os links informacionais a respeito dos dois programas. Utilizando o e-ProInfo e o seu próprio site (http://www.webeduc.mec.gov.br/midiaseducacao/index.php) como ambientes de aprendizagem, o Programa de Formação Continuada em Mídias na Educação disponibilizava uma série de módulos de estudos, uma vez objetivar "ser uma referência para cursos on line" (BRASIL, 2007e), promovendo a formação continuada para o "melhor uso" das mídias, a "avaliação crítica" de sua aplicabilidade e o desenvolvimento das "habilidades e competências necessárias" no campo das tecnologias educacionais (BRASIL, 2007f).

Os programas mais antigos e recentes, até por sua complexidade e posição estratégica em meio à política conduzida pela SEED, representavam todavia aqueles que disponibilizavam acervo digital e eletrônico mais volumoso. Tratavam-se eles de o Salto para o Futuro, TV Escola, Programa Nacional de Informática na Educação (ProInfo), Rádio Escola, Universidade Aberta do Brasil (UAB) e Escola Técnica Aberta do Brasil (e-Tec Brasil). À exceção da TV Escola, cujos dados encontravam-se 
disponíveis na página da SEED, os demais programas mantinham suas home pages, com diversos links, em geral, acessíveis a qualquer usuário.

A TV Escola, canal de televisão do MEC destinado à formação continuada dos educadores, enriquecimento da aprendizagem e melhoria da qualidade do ensino básico, representava o programa que disponibilizava o acervo mais rico. Em meio a informações gerais sobre o programa, dois links se destacavam na página da TV Escola - Biblioteca e Salto para o Futuro. Este último remetia a home page do programa homônimo (http://www.tvebrasil.com.br/salto/), produzido pela TVE Brasil e exibido diariamente pelas TVs educativas e comerciais, objetivando a formação continuada e aperfeiçoamento dos professores de educação básica. Através do link Biblioteca, a SEED tornava acessível um conjunto de documentos e textos, produzidos em torno do programa, incluindo projetos e relatórios anuais de gestão da SEED, como o de 1996 que ressaltava: “A programação plurianual da SEED está sistematizada em documentos preliminares, devendo se constituir em base para a definição de uma Política Nacional de Educação a Distância." (BRASIL, 1996, p.2)

Terceiro programa mais antigo da SEED, depois do Salto para o Futuro e TV Escola, o ProInfo encontrava-se também entre aqueles que disponibilizavam maior número de informações, dados e estatísticas a respeito do seu funcionamento e alcance. Apesar de não constar na página da SEED nenhum dispositivo de acesso, o ProInfo também mantinha sua própria home page (http://www. proinfo.mec.gov.br/), na qual se destacava o link Biblioteca que disponibiliza um acervo de documentos e textos, dentre os quais as publicações da "Coleção Informática para a Mudança na Educação". 
Entre os programas mais antigos conduzidos pela SEED, o Rádio Escola representava aquele que menos envolvia textos e documentos, trazendo o seu site (http://200.130.3.122/) poucas informações sobre o programa, além do acesso a três projetos: Educomunicação pelo Rádio em Escolas do Ensino Médio da Região Centro-Oeste (Educomrádio.centro-oeste), Escola Brasil e Séries Rádio Escola, subdividindo-se este último na Série do Professor, Série do Aluno e Série do Radialista que visavam promover atividades pedagógicas no âmbito da alfabetização.

A principal diferença entre os novos programas Sistema Universidade Aberta do Brasil e Escola Técnica Aberta do Brasil em relação aos mais antigos, particularmente TV Escola e ProInfo, é que nem a UAB (http://uab. capes.gov.br/) nem a e-Tec Brasil (http://www.etecbrasil.mec.gov.br/index.php) faziam constar, em suas home pages, históricos ou relatórios de atividades. A não ser na forma de dados e informações gerais sobre seus objetivos, diretrizes, regulamentação, estrutura e funcionamento, além de seus ambientes de trabalho e de comunicação do sistema, destinados à interação entre especialistas e técnicos que atuam junto aos programas. Os seus ambientes de aprendizagem, tendo como base a plataforma Moodle, são disponibilizados diretamente pelas instituições de ensino participantes.

Já o Portal Domínio Público - segundo endereço eletrônico de fundamental importância à pesquisa online que realizamos - apresentava o mérito de armazenar e tornar acessível, entre outros, todo um acervo importante à política educativa brasileira, às vezes até, não encontrado nem mesmo nas respectivas páginas ou sites dos demais programas. Em parceria com a Organização das 
Nações Unidas para a Educação, a Ciência e a Cultura (Unesco), em 2006, foram digitalizadas para aquele Portal por volta de 300 mil páginas de arquivos do Inep e do Conselho Nacional de Educação (CNE) e, além do acervo da Fundação Joaquim Nabuco, a meta para 2007 era "higienizar, restaurar e digitalizar obras raras armazenadas no Colégio Pedro II (RJ)." (BRASIL, 2006c)

A coleção do Portal Domínio Público que interessou, mais diretamente, a nossa pesquisa referia-se às "Publicações sobre Educação", cujo acervo textual em janeiro de 2008 chegava a mais de 2.700 itens cadastrados. Desse total, quase 1.800 itens ou 2/3 registravam autoria do MEC, incluindo secundariamente as diversas secretarias e demais órgãos a ele vinculados. Mesmo descrita como "autor" de apenas três dezenas de registros (BRASIL, 2008d), a SEED aparecia participando da autoria de várias outras obras, muitas vezes, de sua iniciativa, mas cuja normalização bibliográfica obedecia a NBR 6023, de agosto de 2002, da Associação Brasileira de Normas Técnicas (ABNT), que prevê, nos casos de autor entidade: "Quando a entidade tem uma denominação genérica, seu nome é precedido pelo nome do órgão superior, ou pelo nome da jurisdição geográfica à qual pertence." O tempo disponível não foi suficiente para pesquisarmos toda a coleção, mas consultamos 1.200 itens que equivaliam a quase $45 \%$ do total.

A nossa pesquisa online no geral culminou, portanto, na recuperação de um material de extrema relevância, todo ele na forma de cópia digital integral. Inclui o mesmo um conjunto de publicações relacionadas à política nacional de educação a distância, principalmente, nas últimas duas décadas, produzidas, editadas, encomendadas ou patrocinadas, em sua maioria, pelo MEC e órgãos a ele 
vinculados, a destacar a SEED. O material compreende três dezenas de documentos e publicações que - somados àqueles coletados através da pesquisa in loco - servem de base para extrairmos nosso corpus de análise.

Nosso corpus discursivo, enfim, resulta de uma seleção intencional efetuada junto ao conjunto de cinco dezenas de documentos e textos, coletados através dos levantamentos in loco e online, acima descritos. Desse total, constitui nosso corpus os dez textos constantes do Quadro 1, a seguir apresentado:

\begin{tabular}{|c|l|c|}
\hline Texto & \multicolumn{1}{|c|}{ Título } & Ano \\
\hline T1 & $\begin{array}{l}\text { Universidade Aberta do Brasil: democratização do } \\
\text { acesso à educação superior pela rede pública de } \\
\text { educação a distância }\end{array}$ & 2006 \\
\hline T2 & $\begin{array}{l}\text { Política e resultados 1995-2002: tecnologias na } \\
\text { educação básica }\end{array}$ & 2002 \\
\hline T3 & Dois anos da TV Escola & 1999 \\
\hline T4 & $\begin{array}{l}\text { Educação a distância: integração nacional pela } \\
\text { qualidade do ensino }\end{array}$ & 1992 \\
\hline T5 & $\begin{array}{l}\text { 1985: Mensagem apresentada ao Congresso Nacional } \\
\text { Felo Presidente da República, João Baptista de Oliveira }\end{array}$ & 1987 \\
\hline T6 & Projeto Logos II & 1975 \\
\hline T7 & Relatório da teleducação & 1973 \\
\hline T8 & Projeto Saci: relatório no II: parte A & 1968 \\
\hline T9 & Projeto Saci: parte I & $\begin{array}{l}\text { A educação e o treinamento por correspondência: } \\
\text { histórico e potencialidades }\end{array}$ \\
\hline T1 & & \\
\hline
\end{tabular}

QUADRO 1 - Corpus discursivo

FONTE: Pesquisa de campo, através de levantamento in loco e online 
Os dez textos que constituem nosso corpus discursivo foram selecionados a partir de alguns critérios que consideramos importante ressaltar. O primeiro deles é de ordem temporal e se deveu à preocupação em darmos conta de todo o período histórico que abrange o corpus, compreendendo um total de seis décadas que vão desde os anos 1950 até os anos 2000. À exceção das décadas de 1950 e 1980, em relação a cada qual nossa pesquisa resultou tão somente em um único texto (T10 e T5, respectivamente), todas as demais são representadas por intermédio de dois textos que permitem evidenciar, mais sistematicamente, a regularidade do discurso em análise. O parâmetro que serviu de base para essa escolha foi o fato de termos coletado apenas dois textos (T8 e T9) referentes à década de 1960.

O segundo critério, de caráter linguístico, derivou da intenção em selecionarmos textos que representassem os mais diversos tipos ou gêneros de documento oficial. Nosso corpus acaba reunindo desde o artigo publicado em coletânea (T1 e T3), passando pelo ensaio na forma de livro-texto (T10), até a mensagem presidencial (T5) e um conjunto de documentos de natureza político-administrativa. Destacam-se entre esses os projetos (T4, T6 e T9) e os relatórios (T2, T7 e T8), ora referentes a programas específicos ora relacionados à política de EAD em geral.

O terceiro critério, de natureza discursiva, decorreu da necessidade de contemplarmos as temáticas que poderiam representar, de modo mais significativo, o corpus discursivo. Nesse sentido, especialmente os textos referentes às décadas de 1950, 1970, 1990 e 2000, foram selecionados levando-se em conta o fato de se reportarem, já em seus títulos, a quatro discursos que vão se apresentar de suma importância à política nacional de EAD: as tecnologias 
educacionais (T2, T3 e T7), a formação continuada (T6 e T10), a democratização da educação (T1) e a qualidade do ensino (T4).

Por último, o quarto critério que definiu a constituição do nosso corpus teve como base uma opção de ordem epistemológica. O fato de termos selecionado dez textos para análise deveu-se não apenas a uma questão de organização do material e da quantidade de dados que se ofereciam, mas também porque a relação da $\mathrm{AD}$ com o corpus não é de natureza positivista. Além de não considerar o corpus como um conjunto apenas de dados empíricos objetivos, não interessa à $\mathrm{AD}$ nem sua exaustividade nem sua extensividade enquanto materialidade linguística.

\section{Procedimentos de análise}

A sistemática que adotamos para análise do corpus discursivo baseia-se menos em um procedimento de inteligibilidade ou interpretação e muito mais em um esforço de compreensão de como o objeto simbólico produz sentidos e de como estes transcendem ou estão aquém e além das palavras (ORLANDI, 2002, p.26). Isso não significa que estejamos ignorando que o resultado da Análise de Discurso constitui uma interpretação, cuja tradição vai "da hermenêutica à simples explicação do texto." (MAZIÈRE, 2007, p.25) De todo modo, como ressalta Orlandi (1993a, p.117), a AD não constitui um método de interpretação, mas essencialmente de compreensão: “Compreender, na perspectiva discursiva, não é, pois, atribuir um sentido, mas conhecer os mecanismos pelos quais se põe em jogo um determinado processo de significação."

Com base nesse pressuposto, devemos partir inicialmente do enunciado como unidade de referência, 
concebendo-o não como uma estrutura frasal, proposicional ou um ato de linguagem. Mas como uma função de existência pertencente, de forma exclusiva, aos signos: "se eles 'fazem sentido' ou não, segundo que regra se sucedem ou se justapõem, de que são signos, e que espécie de ato se encontra realizado por sua formulação (oral ou escrita)." (FOUCAULT, 2002, p.98-99) Além de não separar o enunciado de suas condições de produção nem de sua estrutura linguística ou das interações de ordem subjetiva (MAZIÈRE, 2007, p.13), ao considerar o enunciado como unidade central da teoria do discurso, a AD o toma em sua singularidade e repetição, dispersão e regularidade, com o objetivo de compreender os acontecimentos discursivos (emergência de enunciados) que produzem e cristalizam efeitos de sentido na sociedade (GREGOLIN, 2006, p.27).

Outras vezes, devemos partir do próprio texto, reconhecendo que o mesmo não se reduz a um objeto empírico, de natureza meramente linguística, com começo, meio e fim. Tomaremos o texto como "uma unidade complexa de significação", observando a sua incompletude textual (manifestada pelo inesgotamento de sentidos que o discurso transporta) como a "condição de existência da linguagem", o olhar sob as condições de sua produção e a sua constituição no processo de interação, no qual o sentido aloja-se no espaço discursivo engendrado pelos interlocutores. No entanto, precisamos observar que o texto não pode ser confundido com o discurso nem muito menos com a unidade de construção deste último, tratando-se na verdade da unidade de análise: "a unidade de construção do discurso é o enunciado mas ele tem de ser referido ao texto para poder ser apreendido no processo de construção do discurso." (ORLANDI; GUIMARÃES, 1988, p.22) 
Assim procedendo, tentamos evitar incorrer no equívoco de uma análise reducionista que leva em consideração apenas parte do texto, "deixando na sombra" o seu contexto (LECOMTE; LÉON; MARANDIN, 1990, p.293). Distintamente da frase, que se organiza entre signos e proposições, o texto é concebido por Pêcheux (1990b) não como produto, mas como processo discursivo que pressupõe condições concretas de produção, diferentes posições de sujeito e várias formações discursivas em torno de uma dominante. Embora possa ser considerado uma unidade completa para efeito de análise, o texto não representa unidade fechada em si mesma, face as suas intrínsecas relações com outros textos, condições de produção e exterioridade constitutiva. O texto constitui "o vestígio mais importante" da materialidade histórica da linguagem, podendo assumir, do ponto de vista da discursividade, desde a extensão de uma simples letra ou enunciado até a condição de um romance completo. Mesmo representando um "dado" da língua, o texto caracteriza muito mais um "fato" discursivo, um objeto simbólico que "organiza a relação da língua com a história no trabalho significante do sujeito em sua relação com o mundo." (ORLANDI, 2002, p.69)

Os enunciados ou textos selecionados deverão ser concebidos como superfície lingüística, uma seqüência oral ou escrita de dimensão variável que representa o objeto empírico, ou seja, o discurso concreto em seu estado puro. Nesses termos, serão submetidos a um processo de de-superficialização que se caracteriza pela transformação do discurso de objeto empírico em objeto discursivo, em objeto de natureza teórica (PÊCHEUX; FUCHS, 1990, p.180). Nessa acepção, o discurso é compreendido como objeto ou espaço teórico linguístico e histórico que nos permite analisar a relação entre a língua e a ideologia. 
A formação do objeto discursivo deve ser descrita, dessa forma, através da identificação das relações que caracterizam uma prática discursiva, estabelecidas entre instituições, processos econômico-sociais, sistemas de normas etc., que definem o campo da exterioridade do objeto, como também da materialidade lingüística que, por sua vez, diz respeito a quem fala, como fala, em que circunstâncias, entre outros condicionantes. Deveremos entender, então, como o texto é produzido, considerando, por um lado, suas condições de produção em sentido estrito - o contexto imediato - e, por outro, suas condições de produção em sentido amplo - o contexto sócio-histórico e ideológico (ORLANDI, 2002, p.26). Precisamos referir o discurso ao conjunto de discursos possibilitados pelas condições de produção (PÊCHEUX, 1990b), cujos elementos estruturais compreendem, por um lado, o referente, o contexto ou a situação de enunciação na qual irrompe e se processa o discurso, que aliás não trata da realidade física, mas de um objeto imaginário, concebido desde o ponto de vista de cada sujeito; e, por outro, os sujeitos do discurso que, antes de constituírem indivíduos isolados, designam lugares delimitados na estrutura de uma formação social e que se fazem representados ou transformados no processo discursivo.

Nesse sentido, a situação de enunciação e o sujeito envolvido nela dizem respeito a uma posição que é determinada pela relação com outras posições de sujeito, derivadas das diversas formações discursivas que se debatem em meio a uma conjuntura sócio-histórica. Em outras palavras, trata-se de evidenciarmos o esquema enunciativo, determinando os papéis relacionados a sua produção, destacando-se aqueles ocupados pelo locutor e interlocutor, o enunciador responsável pelo discurso e 
o seu destinatário. Entender a dimensão desses elementos, identificando inclusive cada participante ou grupo envolvido, com suas expectativas materiais ou simbólicas concretas e específicas, evita-nos incorrer no equívoco de considerar o sujeito como origem do sujeito, ou melhor, "o sujeito do discurso como origem do sujeito do discurso." (PÊCHEUX, 1988, p.158)

Levando em consideração as diversas modalidades enunciativas (status ou direito de fala, lugares institucionais, posição ocupada), deveremos entender o discurso como o lugar da dispersão e da descontinuidade do sujeito em relação a si próprio, "um espaço de exterioridade em que se desenvolve uma rede de lugares distintos." (FOUCAULT, 2002, p.62) Ao mesmo tempo em que é interpelado por uma formação ideológica e discursiva, o sujeito do discurso é igualmente sobredeterminado pelos dispositivos de comunicação que lhes impõe lugares, papéis e comportamentos definidos (CHARAUDEAU; MAINGUENEAU, 2006, p.115) e por uma memória discursiva, "à medida que uma formulação-origem regressa à atualidade de uma 'conjuntura discursiva' que denominamos de efeito de memória." (COURTINE, 1981)

Definido o objeto e o sujeito discursivo, cabe então reconhecermos que entre um sistema de formação ideológica e um sistema discursivo dá-se o funcionamento do discurso. Mecanismo este que não pertence ao próprio discurso nem à língua, mas resulta da utilização por parte dos sujeitos de elementos lingüísticos, formações ideológicas e discursivas objetivando produzir efeitos de sentidos. Trata-se de atingirmos, em consequência, o processo discursivo, caracterizado pelo fato de que todo discurso se origina de um anterior e, de imediato, aponta na direção de um posterior, significando que representa muito mais 
um "continuum" do que um discurso único, fechado e acabado (ORLANDI, 1993a, p.18).

A nossa atenção, portanto, não deve se limitar à organização do texto, mas àquilo que este organiza em termos de discursividade. O desafio, nesse sentido, será percorrermos o modo como a ordem do discurso materializa-se através da organização do texto, remetendo este a um discurso e vinculando suas regularidades a uma determinada formação discursiva que, finalmente, encontra sentido na respectiva formação ideológica. Segundo Courtine (1981), a formação ideológica possui um caráter específico e compreende posições de classe, o que explica que se pode tratar, a partir de formações ideológicas antagônicas, dos mesmos objetos (como a política de EAD) de forma diferente. A FD, por sua vez, é um componente interligado à formação ideológica, podendo constituir esta várias formações discursivas que se distinguem umas das outras, mantendo relações contraditórias inscritas, necessariamente, em sua própria materialidade lingüística.

Como nosso estudo tem em vista um discurso político por excelência, do mesmo modo que precisamos vincular o funcionamento do discurso a sua exterioridade, torna-se imprescindível compreendermos como o processo discursivo relaciona a FD a uma formação ideológica. Em texto escrito em co-autoria com Catherine Fuchs, Pêcheux (1969 apud MAZIÈRE, 2007, p.51) já atribuía peso fundamental ao estabelecimento dessa relação: "as formações discursivas estão ligadas às superestruturas (no sentido marxista do termo), ao mesmo tempo, como efeitos e como causas. Uma teoria do 'efeito discurso' não pode ignorar esse ponto".

Como o que estará em jogo, enfim, não é mais o texto, mas o próprio discurso em seu modo de funcionamento, 
buscaremos compreender nosso corpus discursivo de acordo com os dispositivos teóricos anteriormente estabelecidos, no caso aqui analisado, à luz das características estruturais da industrialização do ensino. Diferentemente da lingüística, a $\mathrm{AD}$ não trabalha direta nem exclusivamente com as marcas discursivas (formais), mas com propriedades discursivas (materiais) que atribuem sentido ao discurso, referindo a língua à história. $\mathrm{O}$ que importa à $\mathrm{AD}$ é o modo como essas marcas articulam-se no texto ou "se 'encarnam' no discurso. Daí o interesse do analista pela forma-material que lhe permite chegar às propriedades discursivas." (ORLANDI, 2002, p.90)

Sem conseguir dar conta do funcionamento discursivo, as marcas dizem respeito tão somente à organização do enunciado, enquanto as propriedades levam em consideração os vínculos deste com a exterioridade, o contexto sócio-histórico e político-cultural. Apesar de ser indireta a vinculação do texto com os seus condicionantes, não é possível distinguir o discurso sem levar em conta sua historicidade, "pois o estabelecimento da propriedade do discurso é o estabelecimento do funcionamento típico de suas condições de produção." (ORLANDI, 1993a, p.26) Nesses termos, consideramos que as propriedades discursivas da política nacional de educação a distância estariam relacionadas, direta ou indiretamente, às seguintes condições materiais e estruturais da industrialização do ensino: racionalização, divisão de trabalho, mudança de função e especialização, mecanização, linha de montagem, produção de massa, trabalho preparatório, planejamento, organização, métodos de controle científico, formalização, padronização, objetivação, concentração e centralização. 


\section{Dispositivo analítico}

A prática da análise textual precisa levar em conta que um texto comporta uma série de "efeitos possíveis", correspondentes não apenas aos efeitos pretendidos pela instância de enunciação como àqueles produzidos por parte da instância de interpretação (CHARAUDEAU; MAINGUENEAU, 2006, p.180). A compreensão de como um objeto discursivo produz efeitos de sentido acaba, por extensão, dando continuidade a esse processo, colocando em circulação não só uma compreensão, como também uma nova pretensão em matéria de efeitos. "Produzem-se assim novas práticas de leitura." (ORLANDI, 2002, p.27)

Caberá ao analista, apoiado em um referencial teórico-metodológico consistente, problematizar e produzir novas práticas de leitura relativamente ao objeto discursivo, com base em conceitos que lhe são intrínsecos, específicos e, por assim dizer, diferentes daqueles empregados por outros pesquisadores. O que implica numa distinção entre o dispositivo teórico e o analítico que, por sua vez, faz parte e individualiza o teórico, a cada análise efetuada. "Daí dizermos que o dispositivo teórico é o mesmo mas os dispositivos analíticos, não. O que define a forma do dispositivo analítico é a questão posta pelo analista, a natureza do material que analisa e a finalidade da análise." (ORLANDI, 2002, p.27)

Em nossa análise, portanto, o que iremos enfatizar é a relação do objeto empírico (o texto) com o objeto teórico (o discurso). De modo que os textos não serão tratados como "meras ilustrações", pois, na perspectiva da $\mathrm{AD}$, "não há possibilidade de exaustividade extensional/ horizontal, porque todo discurso se estabelece sobre um discurso anterior e aponta para outro (que é o seu futuro)" 
(ORLANDI; GUIMARÃES; TARALLO, 1989, p.32). No próximo capítulo, tentaremos dar conta de como essa relação reflete as condições sócio-históricas de produção de cada texto e do corpus discursivo no seu conjunto. Além disso, buscaremos apontar como essa relação se estabelece sob o impulso do interdiscurso, que permeia todo o corpus, e do intradiscurso, que intervém sobre o âmbito estrito de cada texto.

Aliás, é possível realizarmos vários procedimentos em $\mathrm{AD}$, limitando-nos a um texto e procurando as pistas que o caracterizam, a fim de analisar palavras, expressões ou frases. Para os objetivos delineados neste estudo, pareceu-nos mais adequado entretanto tomar fragmentos de textos diferentes que tratam do mesmo fenômeno. Objetivamos recuperar no corpus pesquisado, numa acepção foucaultiana, "os traços discursivos suscetíveis de permitir a reconstituição do conjunto das regras que, num momento dado, definem ao mesmo tempo os limites e as formas da dizibilidade, da conservação, da memória, da reativação e da apropriação" (REVEL, 2005, p.18).

Nessa perspectiva, mediante escolha intencional, tomamos como unidade significativa de análise do nosso corpus não diretamente cada texto, na sua íntegra, mas a seqüência discursiva de referência (sdr) que melhor representava as propriedades discursivas fundamentais à política nacional de EAD. Seguindo Courtine (1981), partimos do pressuposto de que a produção de uma sdr apresenta-se fortemente associada à difusão e circulação de todo um conjunto de textos, de natureza e procedência diversas, que a precederam e a prepararam, dos quais constitui o ponto culminante, que os sucedem e os respondem, formando, por conseguinte, o domínio de atualidade do acontecimento discursivo que representa. 
Em complemento a esse critério de representatividade, boa parte das seqüências selecionadas foi extraída do tópico correspondente à introdução de cada texto. São exemplares, neste sentido, as sdr 1, 3, 6 e 10 que representam uma espécie de introdução à introdução. As sdr 2, 4 e 8, por sua vez, fazem parte da introdução. Por último, as sdr 5, 7 e 9 encontram-se no entremeio dos respectivos textos. A organização de cada seqüência leva em conta um conjunto significativo de parágrafos, aos quais estamos denominando de segmentos discursivos, formados por diversos tipos de fragmentos (palavras, expressões, frases, enunciados, séries discursivas etc.). Considerando que a $\mathrm{AD}$ não se preocupa diretamente com a forma ou a extensividade do texto, mas com a sua discursividade, os segmentos apresentam dimensão variada, compreendendo desde dois a sete parágrafos, havendo uma ênfase de parte das seqüências em ser composta por três segmentos (sdr 1, 2, 3, 6 e 8).

Cada sdr não só corresponde, assim como visa representar um dos dez textos que constituem nosso corpus discursivo. Elegemos a sdr 1 como seqüência-modelo, pela importância especial que ela encerra, conforme esclarecemos no próximo capítulo. Ela assume, dessa forma, um propósito bem mais amplo que as demais sequiências, contribuindo para vislumbrarmos como as condições de produção ajudam a organizar e transcender a regularidade do discurso da industrialização do ensino. Por um lado, examinamos como a própria sdr 1 organiza-se tanto lingüística como discursivamente, dando ênfase a sua intratextualidade e intradiscursividade. Por outro, tentamos dar conta de como a sdr 1 e o T1 como um todo organizam-se em termos de intertextualidade e interdiscursividade face aos mesmos (seqüência e texto) e a outros 
textos e discursos presentes, seja no seu interior seja em sua exterioridade.

Daí nosso cuidado em decompor e analisar a sdr 1 e o T1 da forma a mais detalhada e abrangente possível. O que implicou, em primeiro lugar, identificarmos a situação de enunciação que envolve o discurso, incluindo o lugar e tempo em que ocorre, além do lugar social e a posição do sujeito falante e destinatário. Em segundo lugar, procuramos evidenciar como esses sujeitos, ou melhor, os sujeitos da história comportam-se entre si, fazendo uso da voz ou sendo induzidos ao silêncio, o que nos levou a identificar, por um lado, um sujeito silenciado e, por outro, um sujeito ao mesmo tempo determinado, competente e autorizado.

Em terceiro lugar, foi-nos extremamente importante desvendar a materialidade do discurso, compreendendo desde o gênero textual e a forma de linguagem até a estratégia e o tipo de discurso prevalecente. Do que resultou apontarmos um discurso nos padrões de um artigo de natureza acadêmico-científica, apresentado de forma didática e com pretensões dialógicas, porém marcadamente autoritário. Em quarto lugar, preocupou-nos examinar a continuidade e a descontinuidade do discurso que, por conseguinte, revelou encontrar-se a sdr 1 intensamente afetada por uma regularidade discursiva. Em quinto lugar, buscamos esclarecer como os enunciados apontam na direção de acontecimentos discursivos, concebidos como subdivididos em três níveis de acontecimentos interdependentes e correspondentes às instâncias da produção, difusão e circulação do discurso.

Por último, conjuntamente com o T1, a sdr 1 é tomada para entendermos como o sistema de enunciabilidade do discurso em torno da política nacional de EAD é organizado para fazer prevalecer a industrialização do ensino 
enquanto formação discursiva dominante. Seguindo esse pressuposto, todas as demais sequências discursivas de referência têm o propósito de evidenciar, fundamentalmente, a incidência das características da industrialização do ensino sobre cada texto, através de fragmentos que lhe são correspondentes, mesmo que reiterados na forma de paráfrases ou famílias parafrásticas ${ }^{10}$. Quando as correlacionamos sob o prisma de sua materialidade e, sobretudo, de sua própria historicidade, tais sequências enfim dão sentido ao nosso corpus discursivo. Material este composto por um conjunto de enunciados, resultante de um discurso produzido em uma situação concreta de enunciação por sujeitos e, no evento dessa enunciação, materializado em textos, entendidos como uma unidade lingüística concreta e de sentido, construída segundo regras e princípios discursivos determinados sócio-historicamente.

Nosso esforço para conceber o discurso em torno da política nacional de EAD como remetendo à formação discursiva industrialização do ensino não ignora, evidentemente, sua capacidade de interagir com outras formações discursivas. Mesmo porque a identidade de uma formação define-se, também, pela rejeição de algumas unidades

10 A paráfrase, que trata de uma relação entre enunciados equivalentes e que pode levar à reformulação de um pelo outro, representa um dos fragmentos mais recorrentes evocados pelos textos. "Assim como a reformulação, a paráfrase é o vetor pelo qual se marca a heterogeneidade no discurso, seja ela mostrada ou constitutiva." (CHARAUDEAU; MAINGUENEAU, 2006, p.366) Outras figuras de linguagem que, também, aparecem demarcando os textos são a metáfora (que designa um referente por intermédio de um signo distinto daquele usualmente utilizado) e a metonímia (que mantém com o signo uma relação, como aquela da parte pelo todo), as quais representam a "presença da historicidade na língua." (ORLANDI, 2002, p.67) 
de sentido ("negativas") e projeção de outras ("positivas"), construídas nas formações com as quais estabelece relação. Para resguardar sua própria identidade, define Maingueneau (1993, p.122), o discurso apenas consegue "relacionar-se com o Outro do espaço discursivo através do simulacro que dele constrói. Chamaremos discurso agente aquele que se encontra em posição de 'tradutor', de construtor do simulacro, e discurso paciente aquele que desta forma é traduzido."

Além disso, tudo indica ser importante adotarmos procedimento talvez próximo ao que preocupou Foucault, a partir dos anos 1970, quando devota suas análises à relação existente entre os grandes tipos de discurso e as condições sócio-históricas de seu aparecimento e formação, marcando assim "a passagem metodológica da arqueologia à genealogia" (REVEL, 2005, p.38). Uma das pretensões da arqueologia, preconizava o próprio Foucault (2002, p.186), é evidenciar as relações entre as formações discursivas e não discursivas, determinando até que ponto as regras de formação que regem os enunciados vinculam-se a sistemas não discursivos, entre os quais os processos econômicos, os fatos e as instituições políticas. Em entrevista a Rouanet e Merquior (1971, p.24), o autor chamava atenção que essas relações no entanto seriam bem mais complexas do que a pura e simples expressão do que denominava das formas econômicas e sociais pré-discursivas, muito embora todas as regras que definiam os objetos, as posições do sujeito e a forma dos conceitos originavam-se de tais formações: "É somente a partir dessas regras que se poderá chegar ao estado terminal do discurso, que não exprime, portanto, essas condições, ainda que estas o determinem." (ROUANET; MERQUIOR, 1971, p.24) 
O dispositivo analítico acima descrito tenta seguir nessa direção, muito embora não ignoremos que poderá correr alguns riscos. Em primeiro lugar, o risco de envolvimento não só com a análise, como também com a construção do corpus, pode abrir o texto para o contexto no qual trabalhamos enquanto pesquisadores. Em segundo lugar, o risco de esbarrar no fato de que as condições de produção do discurso, em que pese sua importância para a construção do corpus de estudo, podem se tornar orientações teóricas capazes de condicionar o processo de compreensão. Inspirada na acepção marxista de condições econômicas de produção, a noção de condições de produção do discurso teria estabelecido uma correlação fortemente mecanicista entre discurso e classes sociais. "Em uma perspectiva que deve muito a Foucault, ela cedeu a vez a uma visão mais complexa das instituições discursivas e da relação entre o interior e o exterior do discurso" (CHARAUDEAU; MAINGUENEAU, 2006, p.114).

Por último, correríamos o risco de superestimar o papel das formações sociais e ideológicas, perdendo de vista a capacidade de renovação do discurso. A estratégia para evitar incorrer nesses e eventuais outros riscos, sugerem Charaudeau e Maingueneau (2006, p.142), será enfatizar o discurso como acontecimento, cuja compreensão se dá nos marcos do próprio "corpus e não fora dele". Na Análise de Discurso, salienta Cazarin (2005), é consenso o fato de que a própria formação discursiva "não é algo delimitado a priori porque se 'constrói' e se configura como gesto de interpretação." O que implica reconhecermos que a confirmação da pressuposição de que o discurso da industrialização do ensino refere a formação discursiva predominante na política nacional de educação a distância dependerá, também, de nosso gesto de compreensão. 


\title{
A EAD COMO PRÁTICA POLÍTICO-SOCIAL E DISCURSIVA
}

\begin{abstract}
Ao tomarmos o discurso como efeito de sentidos entre interlocutores, englobando os enunciados produzidos por eles no processo de enunciação, consideramos a princípio que o discurso em torno da política nacional de educação a distância é regulado por uma exterioridade sócio-histórica e ideológica que é determinante às regularidades lingüísticas, seu uso e sua função junto àquele discurso. O que implica inscrevermos o enunciado numa formação discursiva determinada, sobretudo considerando que tendem a habitar o nosso corpus de análise sujeitos e posições institucionais, políticas e ideológicas bem definidas, emanadas de um Estado de orientação capitalista, ao qual não se apresenta nada contraditório transformar um discurso em instrumento estratégico ao processo de institucionalização da industrialização do ensino no país.

Nesse sentido, não pretendemos adotar em nossa análise uma ou outra tendência tradicional dos estudos da linguagem: nem o método histórico-comparado que prevalece no século XIX, considerando a linguagem como "produto da história"; nem o estruturalismo do século XX que define a linguagem como uma estrutura (ORLANDI, 1993a, p.16). Além disso, seguindo Foucault (2001b, 2002,
\end{abstract}


2004), nosso estudo distancia-se dos cânones da história convencional, de "fazer a história" da educação a distância ou da política de EAD no Brasil contemporâneo, objetivando em contrapartida reconhecer a lógica que rege a ordem do discurso em torno de tal política. O fato de concebermos esse discurso como uma seqüência ou "série de acontecimentos" reporta-nos, no entanto, ao âmbito da história (FOUCAULT, 2001a, p.258).

Ao invés de partir da história para o texto, como se predominasse uma relação de causa e efeito, tomamos o textual enquanto materialidade histórica que comporta sua própria temporalidade e historicidade, ainda que relacionada à realidade sócio-histórica. Se em algum momento, porém, for necessário fazer uma história dos objetos discursivos, não importará tanto remeter a sua origem, mas percorrer o nexo das suas regularidades. Será preciso compreender o discurso, conforme Foucault (2002, p.28), mediante a emergência dos acontecimentos discursivos, na sua pontualidade ou dispersão temporal que o torna capaz de ser transformado, esquecido ou repetido. Mesmo como estrutura, a regularidade não impede a "força de organização do sentido", própria aos acontecimentos discursivos que, de modo geral, apresentam-se únicos (MAZIÈRE, 2007, p.30).

Levando essa premissa às últimas consequências, o discurso da industrialização do ensino assume uma regularidade tal na contemporaneidade que parece investir, como diria Foucault (2004, p.17), atributos de uma vontade de verdade que não só profetiza o futuro da educação, mas contribui para sua realização, exercendo tanto pressão quanto poder de coerção sobre os demais discursos. Apoiada em um suporte institucional, como os outros sistemas de exclusão, essa vontade de verdade mobiliza 
um conjunto de práticas sociais, incluindo a pedagogia, sendo ainda mais decisivamente reconduzida pelo modo como o saber é valorizado, distribuído e aplicado em meio à sociedade.

Ressalta Pêcheux (1988, p.145) que exercem papel decisivo nesse sentido - seja em meio ao suporte institucional seja em meio ao tecido social - os aparelhos ideológicos de Estado, constituídos em lugar e meio de materialização privilegiados dessa vontade de verdade ou, de forma mais abrangente, da ideologia dominante. "É pelo estabelecimento dos AIE, aonde esta ideologia é realizada e se realiza, que ela se torna dominante." (ALTHUSSER, 1992, p.106) Em outras palavras, a ideologia dominante pressupõe uma formação discursiva, cuja dinâmica é acionada por intermédio de uma prática discursiva.

Considerando o discurso como uma prática por excelência, Foucault (2002, p.51) nos adverte que cabe ao analista do discurso desvelar a complexidade e densidade das práticas discursivas, evidenciando que uma mudança na ordem do discurso supõe, acima de tudo, transformações na própria ação social, o que "consiste em não aceitar nenhum discurso fora do sistema de relações materiais que o estruturam e o constituem". A marca da AD, por assim dizer, é a reflexão sobre a linguagem enquanto prática.

$\mathrm{Na}$ realidade, o discurso representa não apenas um conjunto de textos, mas uma prática em meio às "práticas que constituem a sociedade na história, com a diferença de que a prática discursiva se especifica por ser uma prática simbólica." (ORLANDI, 2002, p.71) Ainda assim, a prática de produção do discurso não constitui exceção alguma no conjunto das diversas práticas, posto que, igualmente a essas, funciona como interpelação (PÊCHEUX, 
1988, p.267), através da qual os aparelhos ideológicos de Estado interpelam os indivíduos em (seus) sujeitos (ALTHUSSER, 1992). Para vislumbrar a regularidade do discurso enquanto prática, devemos então analisar não os seus produtos mas, principalmente, os processos de sua produção. Estudar o seu funcionamento ideológico pressupõe reconstituí-la como prática entre as demais, sobretudo, objetivando descrever como se formam seus objetos e suas modalidades de enunciação, conceitos e escolhas teóricas (FOUCAULT, 2002, p.211).

A categoria prática discursiva proposta por Foucault indica uma "inovação teórica, no fundo materialista" (LECOURT, 1971, p.51), que amplia a noção bakhtiniana de que a palavra enquanto signo social investiria o fenômeno ideológico, demandando uma análise capaz de descrever o seu funcionamento como instrumento da consciência e elemento fundamental a toda ideologia. Conforme já nos alertava Bakhtin (1988, p.32), como o domínio dos signos coincide com o domínio do ideológico, pois não há ideologia sem signo e tudo que é ideológico assume valor simbólico, as formas do signo são determinadas não só pela organização social dos indivíduos, como também pelas condições em que a sua interação acontece: "Uma modificação destas formas ocasiona uma modificação do signo."

A política nacional de educação a distância, sob esse prisma, constitui não apenas uma prática política ou social, como também - e ao mesmo tempo - uma prática discursiva. "A política é um campo de batalha em que se trava uma guerra simbólica para estabelecer relações de dominação ou pactos de convenção." (CHARAUDEAU, 2006, p.46) Segundo Maingueneau (1997, p.82), a categoria prática discursiva é muitas vezes adotada como uma variante de FD para designar que o discurso representa 
uma modalidade de ação social, seja numa perspectiva pragmática seja numa perspectiva marxista que o concebe como práxis. O melhor exemplo disso seria a seguinte definição de Foucault (2002, p.136): "um conjunto de regras anônimas, históricas, sempre determinadas no tempo e no espaço, que definiram, em uma dada época e para uma determinada área social, econômica, geográfica ou lingüística, as condições de exercício da função enunciativa."

Assim como as práticas não discursivas, o discurso também adquire importância de sistema e objeto de luta. Por um lado, tanto a organização da sociedade como das idéias que nela circulam fazem parte de um mesmo movimento histórico, distribuído através de regimes de manifestações das mais diversas ordens, desde econômica até cultural, nenhuma delas podendo se traduzir em realidade ou origem das demais. Por outro lado, revelando a forte influência das hierarquias sociais sobre as formas de enunciação, o signo (discurso) transforma-se em "arena" importante da luta de classes (BAKHTIN, 1988, p.43). No fundo, optar por prática discursiva ao invés de discurso é assumir uma posição teórica, sublinhando "obrigatoriamente que se considera o discurso como uma forma de ação sobre o mundo produzida fundamentalmente nas relações de força sociais." (CHARAUDEAU; MAINGUENEAU, 2006, p.396).

Como as políticas educativas exprimem relações de força na sociedade, essas relações também vão prevalecer nas práticas discursivas (ORLANDI, 2002, p.40). De sorte que o sentido e a linguagem não se superpõem, mas encerram uma das dimensões constitutivas das relações econômicas e sociais (MAINGUENEAU, 1993, p.188), das relações de saber e poder, não traduzindo o discurso tão somente os sistemas de dominação, mas aquilo 
propriamente pelo que se luta para enfim apoderar. "Todo sistema de educação é uma maneira política de manter ou de modificar a apropriação dos discursos, com os saberes e os poderes que eles trazem consigo." (FOUCAULT, 2004, p.44) Ao mesmo tempo expressando e fazendo parte do universo das transformações sociais, segundo ainda Foucault (1997, p.12), uma prática discursiva se transforma como resultado de modificações ocorridas dentro dela, em outras práticas discursivas ou no âmbito mais amplo das formas de produção, relações sociais e instituições políticas.

Concorre, nessa direção, o fato de que as ideologias não se restringem às idéias, mas ganham sentido sobremodo enquanto forças materiais (PÊCHEUX, 1988, p.129). Um produto ideológico investe uma realidade como qualquer corpo físico mas, além disso, ainda reflete outra realidade exterior. "Tudo que é ideológico possui um significado e remete a algo situado fora de si mesmo." (BAKHTIN, 1988, p.31) Como a ideologia em geral e as ideologias regionais (política, religiosa, jurídica, pedagógica etc.) realizam-se, essencialmente, através dos AIE, o ideológico é inerente tanto ao aparelho quanto a sua prática. "Esta existência é material." (ALTHUSSER, 1992, p.89)

Não por acaso, os grupos sociais acabam intervindo nas políticas públicas para direcionar estas de acordo com suas perspectivas e interesses. Por isso mesmo, é preciso compreender a função que exerce o discurso no campo das práticas não discursivas e, por extensão, o regime e os processos em que se dá a sua apropriação, isto é, o direito e a competência para acessar, falar, entender e investir o discurso nas instituições e tomadas de decisão. Em outras palavras, conforme sugere Courtine (1999, p.16), a questão que se coloca é compreender "como um discurso político 
funciona? O que é enunciar, manter o fio de um discurso, mas também 'repetir', 'lembrar', 'esquecer', para um sujeito enunciador tomado nas contradições históricas do campo político?"

O discurso se define, pois, pela capacidade em relacionar, sistemática e positivamente, seus elementos a outros discursos e a todo um campo não discursivo (FOUCAULT, 2002, p.210). Conforme Pêcheux (1968), retomado por Henry (1990, p.24), o discurso se constitui em instrumento da ação política, cuja função é transformar, através da prática discursiva, as relações sociais e estas, por sua vez, a demanda social. O discurso político, mais particularmente,

não esgota, de forma alguma, todo o conceito político, mas não há política sem discurso. Este é constitutivo daquela. A linguagem é o que motiva a ação, a orienta e lhe dá sentido. A política depende da ação e se inscreve constitutivamente nas relações de influência social, e a linguagem, em virtude do fenômeno de circulação dos discursos, é o que permite que se constituam espaços de discussão, de persuasão e de sedução nos quais se elaboram o pensamento e a ação políticos. A ação política e o discurso político estão indissociavelmente ligados, o que justifica pelo mesmo raciocínio o estudo político pelo discurso (CHARAUDEU, 2006, p.39). 
Ao considerar que toda mudança política pressupõe uma mudança discursiva, ainda que nem sempre concomitante, a $\mathrm{AD}$ reconhece uma relativa autonomia do campo discursivo em relação ao político. De sorte que a prática discursiva constitui não apenas uma das tantas formas da prática política, como sobremaneira um dos domínios mais importantes da estratégia política. Além de ser essencial à determinação dos posicionamentos assumidos politicamente, é mediante o discurso que podemos avaliar "as contradições, as indeterminações e oposições." (FORGET, 1994, p.29) Antes, porém, de evidenciarmos como a própria prática discursiva afeta nosso corpus de análise, faz-se necessário tentarmos reconstruir a sua historicidade, dando ênfase às condições de produção de cada texto selecionado.

\section{CONDIÇÕES DE PRODUÇÃO DO DISCURSO EM TORNO DA EAD}

Inscrevendo-se num cenário, ao mesmo tempo, de educação para o século XXI e de continuidades da política educativa, a escolha do T1 - "Universidade Aberta do Brasil: democratização do acesso à educação superior pela rede pública de educação a distância" - como texto central de nossa análise não poderia ter sido aleatória. Conforme veremos adiante mais detalhadamente, embora volte sua atenção para a educação superior, representa aquele texto um "marco" dos discursos oficiais que, pelo menos, nas últimas seis décadas, têm contribuído para afirmar e legitimar o processo de industrialização do ensino no país que constitui, por sua vez, não apenas a consolidação da política nacional de educação a distância, como também 
a modernização até as últimas conseqüências da política educativa em geral.

A produção, difusão e circulação do T1 acontecem, portanto, em meio a uma conjuntura excepcional, marcada principalmente pela expansão crescente das TICs, da EAD e da mercantilização da educação em todo o mundo; consolidação da SEED e da política nacional de educação a distância; crescimento da demanda e ampliação da oferta de ensino superior a distância e semi-presencial; e incremento da política de inclusão social como um dos pilares deflagradores do segundo mandato do governo Lula. "Buscando revolucionar a educação, rumo à transformação inclusiva, dois grandes temas têm ocupado a agenda do MEC: a democratização do acesso e a qualidade da educação no País." (HADDAD, 2006, p.7)

A EAD teria chegado, enfim, ao seu terceiro estágio no Brasil. Em primeiro lugar, suplantado a fase do idealismo que atribuía à educação a distância a capacidade revolucionária de equacionar os graves problemas educacionais. Em segundo lugar, superado a fase da normalização, responsável por inserir a EAD entre as prioridades da educação nacional, com ênfase para a educação de adultos. "Finalmente, a emancipação reflete os parâmetros em que hoje a EAD é concebida, como única modalidade capaz de absorver os rumos do desenvolvimento tecnológico e, nesse sentido, é proclamada como a educação da era da informação." (FARIAS, 1998, p.90)

Sua importância crescente no Brasil reflete a tendência mundial de incremento da EAD, patrocinada por organismos internacionais como a Organização dos Estados Americanos (OEA), o Conselho da Europa e a Unesco (OILO, 1999; UNESCO, 1999), ensejando à Organização Mundial do Comércio (OMC) a se mobilizar "ativamente 
para suprimir todas as barreiras ao comércio internacional de 'mercadorias educativas'." (NOBLE, 2000) Apropriadas por investidores privados e praticamente sem fronteiras, as tecnologias de EAD favorecem a expansão do mercado educativo, ampliando o alcance e acelerando substancialmente "a reprodução do capital no campo da educação." (BATISTA, 2002)

Aos governos nacionais cabe desenvolver políticas de expansão da EAD que passa a representar o modelo que melhor pode cumprir as prioridades educacionais, "dentro de uma racionalidade superior às modalidades presenciais." (PRETI, 1998, p.24). Não sem motivos, em 2003, o governo Lula inicia seu primeiro mandato considerando que: "A Educação a distância é instrumento essencial para democratizar o acesso à educação, facilitar a formação continuada e elevar o padrão de qualidade da educação." (BRASIL, 2003, p.62)

A própria ênfase do $\mathrm{T} 1$ sobre o Sistema Universidade Aberta do Brasil representa, no fundo, um novo deslocamento de sentido, promovido pela mesma política que, até então, concentrava sua atenção na difusão da TV Escola, ProInfo e Proformação. Esses programas constituem, por sua vez, os ícones do T2 - "Política e resultados 19952002: tecnologias na educação básica", cuja "elaboração" foi incumbida à Diretora do Departamento de Política de Educação a Distância da SEED/MEC. Concebido como "um rápido balanço" das ações da SEED durante os dois mandatos do governo Fernando Henrique Cardoso, o texto representa em última instância um libelo em defesa das "tecnologias na educação básica", tendo em vista que: "Este foi um compromisso assumido no Planejamento Estratégico desenhado para o período 1995-1998. A Secretaria da Educação a Distância vem honrando esse compromisso." (BRASIL, 2002a, p.8) 
Em pleno processo de transição para um governo de oposição, eleito por uma coligação de centro-esquerda (o governo Lula), o T2 é publicado em dezembro de 2002, voltando sua ênfase à "Política e resultados" alcançados por parte da SEED. “Toda a sua vasta produção editorial neste período serve justamente ao propósito de orientar a implementação da política de novas tecnologias na educação pública. Procuram convencer sem impor, liderar sem submeter." (SOUZA, 2002) A pretensão do governo Fernando Henrique Cardoso em liderar as mudanças no sistema educativo, "sem submeter", advém desde quando a TV Escola constitui o carro-chefe da política de EAD.

O T3 - "Dois anos da TV Escola" - tem sua produção, difusão e circulação nesse período, representando o primeiro artigo de uma coletânea em que o próprio presidente da República assina o texto de "Abertura", contendo oito páginas, o dobro da média dos artigos escritos por autoridades e especialistas em EAD do Brasil, Argentina, Canadá, Chile, Colômbia, Espanha, Estados Unidos, França, Inglaterra e México: "acho importante que a gente entenda que o acesso a essas técnicas mais modernas também faz parte do processo de cidadania. Porque é permitir que a população participe dos avanços do progresso técnico que vão ser decisivos nos séculos vindouros." (CARDOSO, 1999, p.15)

Logo no discurso de posse em 1995, por ocasião do seu primeiro mandato, o presidente Fernando Henrique Cardoso faz questão de conclamar o engajamento das "nossas TVs numa verdadeira cruzada nacional pelo resgate da cidadania através do ensino", traduzindo a importância que a TV, particularmente, passa a ter na política educacional (CARDOSO, 1994, p.129). Não por acaso, o T3 integra a coletânea "2 anos da TV Escola", publicada 
pela SEED/MEC em 1999, início do segundo mandato daquele governo. "É mais uma contribuição aos professores e outros profissionais que trabalham com educação a distância, comprometidos com a construção de um novo ensino nas escolas públicas do País." (BRASIL, 1999)

Editada através da "Série de Estudos: Educação a Distância", cuja tiragem em 1999 chega a 110 mil exemplares por título (BRASIL, 2002b, p.30), a coletânea publica, "em versão condensada" (a versão integral seria disponibilizada no site da SEED/MEC), as palestras apresentadas durante o Seminário Internacional sobre os 2 anos da TV Escola, realizado em Brasília, entre os dias 30 de junho e $1^{\circ}$ de julho de 1998. Reunindo tendências e experiências da EAD em nível mundial, o Seminário mostra-se "importante" graças, entre outros, aos seguintes motivos: "Comprovou o valor das novas tecnologias na capacitação de professores" e "reforçou nossa confiança na TV Escola, no momento em que comemorávamos um avanço significativo do Programa em escolas de todo o País" (BRASIL, 1999).

Além de "ter, efetivamente, posto em prática aquilo que era aspiração de todos nós" (CARDOSO, 1999, p.11), o próprio ministro da Educação - também responsável pela "Apresentação" do T2 - é quem assina o T3, fazendo questão de reiterar o seguinte: “Hoje, 50 mil escolas estão assistindo a este seminário, em todo o Brasil. Nos confins da Amazônia, em São Paulo, no Rio de Janeiro - 50 mil escolas estão nos assistindo hoje." (SOUZA, 1999, p.19) De fato, o avanço da EAD no país mostra-se considerável, ao levarmos em conta sobremodo a sua expansão entre o início e o final dos anos 1990, quando a TV Escola já alcançava "50 mil escolas". 
O T4 - "Educação a distância: integração nacional pela qualidade do ensino" - marca essa fase, graças, em particular, a dois fatores de extrema importância: a conjuntura política em que se dá sua produção, difusão e circulação e a proposição de uma política nacional de EAD. Datada de 1992, a publicação do texto coincide com o processo de impeachment e renúncia do presidente Fernando Collor de Mello que, sem precedentes na história do país, altera toda a vida nacional. Tanto que o T4 é publicado em duas versões. Como faz referência ao "Presidente da República" e "Vice-Presidente da República no exercício do cargo de Presidente da República", sugere a primeira versão ter sido editada por ocasião do afastamento de Collor de Mello em 2 de outubro de 1992 e conseqüente ocupação da Presidência pelo seu vice.

A segunda versão (a qual adotamos em nosso corpus) teria sido reeditada logo em seguida à renúncia do presidente e posse definitiva de Itamar Franco, em 29 de dezembro daquele ano. O T4 já se refere a este último como "Presidente da República Federativa do Brasil", embora mantenha o texto a data anterior de sua publicação e a própria ênfase sobre a "modernização" nacional: "A modernização do País passa necessariamente pela educação e esta precisa utilizar os recursos tecnológicos disponíveis para se fazer presente, co-partícipe, do processo de modernização e, sobretudo, promotora e indutora da sociedade do futuro." (BRASIL, 1992, p.9)

Durante o governo Itamar Franco, são esboçadas propostas consistentes de uma política nacional de teleducação e intensificada a cooperação internacional, "em busca da incorporação da experiência estrangeira nas reflexões sobre uma forma brasileira de Educação a Distância" (BRASIL, 1994, p.7). Com efeito, o T4 dedica especial 
atenção à política de EAD que, em plena transição para o século XXI, torna-se cada vez mais estratégica à educação nacional. Elaborado e publicado sob os auspícios da Coordenadoria de Educação a Distância/MEC e apoiando-se, de modo especial, no Programa Um Salto para o Futuro, o texto não deixa de representar um parâmetro importante da política que será retomada, mais adiante, por intermédio do T1, T2 e T3: "O documento contempla a Política e o Programa Nacional de Educação a Distância ou Teleducação, suas tendências e perspectivas." (BRASIL, 1992, p.3)

Essa ênfase sobre uma política de EAD já se faz presente junto ao T5 - "1985: Mensagem apresentada ao Congresso Nacional pelo Presidente da República, João Baptista de Oliveira Figueiredo, na abertura da sessão legislativa". Notadamente, quando consideramos que, além da educação no meio rural e nas periferias urbanas, a valorização dos recursos humanos e o desenvolvimento cultural, dentre as linhas mestras do III Plano Setorial de Educação e Cultura, elaborado para o período 1980-1985, encontra-se o "planejamento e modernização técnico-administrativa" (1985: MENSAGEM, 1987, p.513).

O texto assume uma importância especial, mais precisamente, porque faz parte do documento "A educação nas mensagens presidenciais: 1890-1986", uma espécie de coletânea que reúne os capítulos dedicados à educação por parte das mensagens presidenciais, pronunciadas na abertura das sessões legislativas do Congresso Nacional, desde a Velha até a Nova República. Substituindo a "Fala do Trono" do período imperial, as mensagens representam "uma prestação de contas do Poder Executivo, apresentadas pelo Presidente da República ao Poder Legislativo, e, conseqüentemente, a toda a Nação." (BRASIL, 1987, p.9) 
Organizada pelo Inep/MEC, a coletânea é editada em dois volumes. Enquanto o primeiro destina-se ao período que vai do governo Deodoro da Fonseca (1890) até o governo Café Filho (1955), o segundo volume compreende do governo Juscelino Kubitschek (1956) ao governo José Sarney (1986).

Além de constituir o único texto referente à década de 1980 que coletamos durante nossa pesquisa, faz parte o T5 de uma das mensagens mais importantes à República brasileira, a saber, a última mensagem apresentada por um presidente do Regime Militar, João Figueiredo, em 1985. Por seu turno, inscreve-se esta em uma coletânea publicada em 1987, durante o governo Sarney que inaugura um novo processo de redemocratização no país. Sua produção, difusão e circulação se dão, portanto, numa conjuntura excepcional, marcada pela nova Assembléia Nacional Constituinte, à qual o texto "é especialmente dedicado" e que, segundo o ministro da Educação, precisaria levar em conta as "exigências de um mundo" às portas do século XXI: “Nossa juventude deve ser preparada para entrar no mundo do trabalho, para produzir e dominar uma tecnologia de ponta, pois, do contrário, não ficaremos à altura das necessidades do Brasil de amanhã." (BORNHAUSEN, 1987)

A redemocratização do país tem suas bases lançadas durante ainda o Regime Militar, quando o governo Ernesto Geisel começa a acenar com lampejos de abertura política, cedendo a pressões da sociedade, via o que o presidente batizou de um "processo lento, gradual e seguro de aperfeiçoamento democrático". Durante o governo Geisel, integrante do grupo de militares considerados "intelectuais" da Sorbonne, a administração pública é gerida de forma tecnocrática nos moldes de uma empresa privada. 
Os argumentos direcionados à racionalização são muitos, objetivando construir a imagem de competência burocrática, controle político e legitimidade.

A pressa em lançar planos e programas, especialmente, "em momentos de crise pode ser interpretada como uma forma de discurso para compensar a ausência de decisão; [Geisel chegava] mesmo a dizer que prever uma situação era o mesmo que se resolver um problema pela metade!" (FORGET, 1994, p.99) O T6 - “Projeto Logos II" - é reflexo disso, reportando-se a uma das prioridades daquele governo no campo da educação que, como sugere o próprio nome, vem suceder o Projeto Logos I. O que supõe também que, durante a pesquisa, assim como aconteceu ao T4, nos deparamos com duas versões de texto, preferindo optarmos pelo documento referente ao Projeto Logos II, haja vista reunir, além de um novo projeto, uma espécie de diagnóstico que reaproveita parte do texto anterior.

Em resposta à exigência da Lei 5.692 de 1971, que estabelece a obrigatoriedade da habilitação específica de $2^{\mathrm{o}}$ grau para o magistério de $1^{\mathrm{o}}$ grau, da $1^{\mathrm{a}}$ à $4^{\mathrm{a}}$ séries, e prevê a oferta de cursos supletivos "mediante a utilização de rádios, televisão, correspondência e outros meios de comunicação", o Logos I é implementado como projeto-piloto, no início de 1973, ainda sob o governo Garrastazu Médici. Na forma de ensino supletivo a distância para qualificação de professores leigos, representa o projeto "o começo de uma longa caminhada em busca do tempo perdido." (BRASIL, 1975a, p.12) Se no "Projeto Logos I: avaliação", elaborado no final de 1974 e publicado em 1975, fala-se de uma demanda de "aproximadamente 200.000 professores leigos", logo adiante, o "Projeto Logos II" refere-se a um número estimado em 300 mil docentes não 
titulados (BRASIL, 1975b, p.8), manifestando o T6 um dos maiores esforços envidados pelo governo brasileiro, até então, para a formação e qualificação de professores.

Publicado também em 1975, o texto é elaborado pelo mesmo Departamento de Ensino Supletivo/MEC que, na conclusão do "Projeto Logos I: avaliação", declara que, através do Projeto Logos II, pretender-se-á atingir, gradativamente, "todas as regiões do País, procurando, não importa o tempo necessário, habilitar todos os professores leigos em exercício nas primeiras séries do $1^{\circ}$ grau. Depois, outras etapas serão tentadas, até a plenitude dos objetivos: a Universidade Aberta." (BRASIL, 1975a, p.120) Além de se revestir, de certa forma, do espírito "lento, gradual e seguro" do governo Geisel, a declaração antecipa aquilo que, mais tarde, o T1 encarrega-se de anunciar - a Universidade Aberta do Brasil.

Aliás, assim como praticamente acontece ao T1, o "desenvolvimento econômico", o "fator demográfico", a "era tecnológica" e o "tempo da educação permanente" marcam o T7 - o "Relatório da teleducação". Sua produção, difusão e circulação inscrevem-se no final do governo Médici, em plena Ditadura Militar e do "Milagre Brasileiro", para o qual é essencial que a educação não se restrinja ao âmbito escolar, "mas utilize todos os meios disponíveis que lhe garantam maior rentabilidade e produtividade, cobrindo regiões cada vez mais amplas e envolvendo um número cada vez maior de indivíduos." (BRASIL, 1973, p.1) O texto representa, dessa forma, um documento fundamental desenvolvido pelo Programa Nacional de Teleducação (PRONTEL), órgão vinculado à Secretaria-Geral/MEC e dirigido por uma comissão de representantes dos ministérios da Fazenda, Planejamento e Comunicações. 
Criado em fevereiro de 1972, objetiva o PRONTEL "acelerar o processo educacional e racionalizar" a EAD no país. Neste sentido, concentra sua atenção inicial na elaboração do Plano Nacional de Tecnologias Educacionais (PLANATE) que se destina, entre outros propósitos, a estimular o uso de "técnicas de planejamento, administração, desenvolvimento, controle e avaliação", com vistas ao "melhor aproveitamento" dos programas de teleducação (BRASIL, 1973, p.49). Sob a coordenação do PRONTEL, cabe ao Sistema Nacional de Teleducação (SINATE), composto pelo Subsistema MEC, Subsistema Público e Subsistema Privado, executar as metas, projetos e atividades ligados ao PLANATE.

O T7 destaca, dentre essas ações, o Plano Operativo de 1974 que coloca em prática as diretrizes do PLANATE, objetivando oferecer, "em curto prazo, condições para a operacionalização, em níveis crescentes de eficiência, às atuais entidades do SINATE, ao mesmo tempo que abre caminho para ampliação e aperfeiçoamento do Sistema a médio e longo prazo." (BRASIL, 1973, p.50) Com efeito, mesmo elaborado em 1973, ainda sob a vigência do I Plano Setorial de Educação e Cultura que integra o I Plano Nacional de Desenvolvimento (PND), formulado para o triênio 1972/74, o texto já aponta na direção do novo Plano Setorial para 1975/79 que prevê uma "maior e mais efetiva utilização de tecnologias com vistas a superar os déficits quantitativos e qualitativos de escolaridade." (BRASIL, 1976, p.37)

A preocupação em aplicar "tecnologia avançada" na solução desses déficits deriva, no entanto, desde os primeiros anos do Regime Militar, quando se intensifica a atenção dispensada por parte do Brasil à corrida espacial. Um dos principais objetivos da produção, difusão 
e circulação do "Relatório ${ }^{\circ}$ II" do Projeto Saci (Satélite Avançado de Comunicações Interdisciplinares) resulta daí: "Parece evidente que só um programa radical e corajoso - como o SACI - poderá elevar a quantidade e qualidade da educação em futuro próximo e atingir a meta de oportunidade educacional para todos os brasileiros." (BRASIL, 1969, p.1)

Produzido na forma de um segundo relatório acerca daquele Projeto, o documento aborda a evolução do Saci a partir de maio de 1968, durante o último ano do governo Costa e Silva, que delega sua elaboração à Comissão Nacional de Atividades Espaciais (CNAE), extinta em 1971 e transformada no INPE, o atual Instituto Nacional de Pesquisas Espaciais. Vinculada ao Conselho Nacional de Pesquisas e sediada em São José dos Campos-SP, representando portanto a única instância do nosso corpus discursivo localizada fora da capital federal, a CNAE reúne, no início de 1969, mais de uma centena de pesquisadores que realizam estudos, inclusive de doutoramento fora do país, com o objetivo de subsidiar as decisões governamentais: "No momento, um grupo de engenheiros, educadores, sociólogos e economistas estão investigando a educação por satélite como adição eficaz aos esforços do governo para melhorar e ampliar o sistema educativo da nação." (BRASIL, 1969, p.4).

Mais particularmente, como sugere o próprio título, trata o T8 - "Projeto Saci: relatório n ${ }^{\circ}$ II: parte A" - de uma parte do referido relatório que enfatiza desde as condições de infra-estrutura até o impacto econômico do Saci. Neste sentido, além de defender que "a tecnologia de outras nações terá de ser trazida para o Brasil", até como base "para o lançamento de um satélite brasileiro em meados da década 1970/1980", supõe o texto que o governo 
somente implementará o Projeto se tiver a certeza de seu elevado retorno financeiro.

Dessa forma, parte o T8 literalmente do "conceito de formação do capital humano" de Theodore W. Schultz para chamar atenção sobre o "reconhecimento geral do valor da educação" e, por extensão, sobre os argumentos econômicos em favor da implementação do Projeto Saci. Mesmo considerando que são escassos os trabalhos sobre as taxas de retorno dos investimentos em educação no país, reitera aquele texto: "O uso de novos meios em larga escala, através de uma combinação de satélite e transmissores de terra, parece ser a única solução possível para o problema educacional do Brasil." (BRASIL, 1969, p.49)

Essa convicção, ao que tudo indica, resulta de uma série de estudos desenvolvidos pela CNAE, desde 1966, que culminam, dois anos depois, em um relatório de três volumes a respeito do Projeto Saci. O T9 - "Projeto Saci: parte I" - constitui um texto também importante, sobretudo, porque objetiva transcender aspectos de ordem tecnológica. "Os problemas reais, entretanto, não são técnicos; ao contrário, são políticos, econômicos e sociais. São estes aspectos do projeto que formam a essência deste capítulo." (BRASIL, 1968, p.2-1) O capítulo em questão tem como título "Usos e custos de telecomunicações para nações em desenvolvimento", repousando sua ênfase sobre o sistema de televisão educativa via satélite.

$\mathrm{Na}$ realidade, apesar de relacionar entre suas "Referências" discussões sociológicas como "Educação e sociedade no Brasil", de Florestan Fernandes, já se antecipando ao T8 o T9 baseia-se, essencialmente, na economia da educação e da comunicação e na tecnologia educacional. Além de "The economic value of education" de Theodore W. Schultz, fundamenta o T9 uma série de estudos 
estrangeiros recém publicados, tais como, "Human capital" de Gary S. Becker, "Economic aspects of education" de W.G. Bowen, "Technological progress, capital formation and economic growth" de Robert M. Solow, "The diffussion of innovations" de E.M. Rogers, "Innovation in education" editado por M.B. Miles e "Communication and change in developing countries", editado por D. Lerner e W. Schramm. Chamamnos a atenção, ademais, as várias referências a trabalhos apresentados junto a "AIAA Communications Satellite Systems Conference", realizada em Washington-Estados Unidos, em maio de 1966, pelo Instituto Americano de Aeronáutica e Astronáutica (AIAA).

Tomando como base esse referencial, além de apontar um conjunto de estudos empíricos que permite aos "planejadores educacionais" tirar proveito de informações relativas a vários países onde os "meios de educação de massas" são utilizados para compensar os problemas do ensino e do desenvolvimento, o T9 representa um libelo em defesa do Projeto Saci. O Projeto é considerado uma oportunidade ímpar para o Brasil tornar-se vanguarda na aplicação da tecnologia espacial ao sistema educativo. "Poderemos certamente demonstrar ao mundo as possíveis feições da modernização educacional; devemos guiar pensadores, educadores e construtores da nação na inovação pelo progresso" (BRASIL, 1968, p.2-6).

A ideologia da modernização atribui à educação a alavanca do progresso científico e tecnológico, vinculando-a inexoravelmente ao desenvolvimento econômico. Segundo reconhece o próprio presidente Costa e Silva, essa relação se estabelece de forma tão intensa que, desde o início dos anos 1960, o Banco Internacional de Reconstrução e Desenvolvimento (BIRD), braço do Banco Mundial, passou a financiar "os programas educacionais com a mesma 
objetividade com que financia projetos específicos no campo da energia elétrica." (FORGET, 1994, p.82)

O propósito de "guiar" a nação no sentido da "modernização educacional" advém, porém, desde o processo de redemocratização do pós-guerra, mais precisamente, quando emerge o nacional-desenvolvimentismo nos anos 1950. Exemplo sintomático nesse sentido é o T10 - “A educação e o treinamento por correspondência: histórico e potencialidades" - que, segundo o diretor do Serviço de Documentação do Departamento Administrativo do Serviço Público (DASP), constitui um "oportuno Ensaio que o Serviço de Documentação ora oferece aos estudiosos." (PINTO, 1955, p.4) Último texto constante de nosso corpus discursivo, embora represente o primeiro pela ordem cronológica, trata o T10 de um estudo acerca do ensino por correspondência no mundo, com ênfase para seu desenvolvimento junto a importantes universidades norte-americanas.

Em meados da década de 1950, apesar de não mais assumir tamanha relevância quanto no primeiro governo Getúlio Vargas, o DASP tende ainda a exercer influência sobre a administração pública: "Cumprindo o seu programa de disseminação de uma autêntica bibliografia brasileira das ciências administrativas, lança o Serviço de Documentação do D.A.S.P., com o importante trabalho que se vai ler, o $50^{\circ}$ número da série 'Ensaios de Administração'." (PINTO, 1955, p.3) Os quatro números publicados anteriormente intitulam-se "Alguns aspetos da administração de pessoal", "O mandado de segurança", "Notas sobre o Tribunal de Contas da União" e "Previdência social". Além disso, encontram-se no prelo "Problemas fundamentais dos municípios brasileiros", "Introdução ao estudo de documentação", "Um problema 
de administração escolar", "A era do administrador profissional", "Administração financeira e contábil" e o sugestivo "Burocracia e Democracia".

Embora encontremos entre os elementos pós-textuais do T10 a ressalva de que os "conceitos emitidos nos trabalhos divulgados nesta coleção serão de exclusiva responsabilidade dos autores", em meio aos elementos pré-textuais observamos o seguinte: "Realizados com a colaboração de especialistas nos diversos setores da ciência da administração e campos correlatos, terão por objetivo prestar subsídio aos estudiosos, suprindo, na medida do possível, a carência de bibliografia especializada, do gênero, em língua portuguesa." (PIMENTEL, 1955) Um desses "especialistas" é o "técnico de administração" que, sob os auspícios daquele órgão, publica o T10: “O autor, como revelam a profundeza e o brilho demonstrados no tratamento do assunto, era pessoa indicada para elaborar o oportuno Ensaio" (PINTO, 1955, p.4). Além de diretor geral do DASP entre 1961 e 1962, o autor torna-se diretor da Fundação Getúlio Vargas (FGV) e membro da Comissão de Administração Pública Internacional da ONU (ANTONIO, 2008).

A publicação do T10 ocorre em abril de 1955, durante o governo Café Filho, período em que o DASP ainda se localiza no Rio de Janeiro, sede do Distrito Federal. Sua concepção, porém, remonta ao segundo governo Getúlio Vargas, entre os anos 1952 e 1953, "quando nos foi dado estagiar em alguns dos mais importantes e conhecidos estabelecimentos dessa modalidade de instrução, existentes na grande nação amiga." (PIMENTEL, 1955, p.9) O estágio realizado nos Estados Unidos resulta não apenas em um, mas numa série de trabalhos. 
Conforme as "Referências Bibliográficas" do T10, em 1953, o autor elabora "Uma Escola de Administração para todo o Brasil", projeto destinado à criação de um Departamento de Cursos por Correspondência na Escola Brasileira de Administração Pública e de Empresas (EBAPE) da Fundação Getúlio Vargas (FGV). Em 1954, além do "Projeto de reorganização do ensino por correspondência dos cursos de Administração do D.A.S.P.", publica o artigo "A maior organização do mundo em ensino por correspondência", no número de dezembro da Revista do Serviço Público, atualmente editada pela Escola Nacional de Administração Pública, vinculada ao Ministério do Planejamento. No mesmo ano, publica ainda dois trabalhos através da série "Cadernos de Administração Pública", editada pela EBAPE/FGV: "Pequena bibliografia sobre treinamento" e "Alguns aspectos do treinamento" (FUNDAÇÃO, entre 2002 e 2008), este último reeditado pela mesma FGV, em 1966 (UNIVERSIDADE, 2008).

Em 1955, por sinal, torna-se aquele autor o único a conseguir aprovar mais de uma obra junto à série "Ensaios de Administração" do DASP. De sorte que, ao mesmo tempo em que acontece a publicação, difusão e circulação do T10, já se anunciam novos títulos entre os seus elementos pós-textuais: "A sair, do mesmo autor: 'A educação e o treinamento por correspondência (métodos e processos)" e "'O ensino por correspondência no Brasil (o que é e o que pode ser)"'.

Ao que tudo indica, não é por acaso que aquele autor - e, por extensão, o próprio DASP - mostra-se preocupado em dar continuidade aos estudos a respeito de "práticas, processos e técnicas" que conduzem à "boa organização e administração" do ensino por correspondência, 
"em benefício da educação e treinamento em nosso país" (PIMENTEL, 1955, p.10). O primeiro impulso massivo da educação a distância em nível mundial data de 1905, nos Estados Unidos, motivado pela expansão dos correios e uma maior demanda de mão de obra qualificada, abolindo-se "de vez o princípio da coexistência do professor com o aluno num mesmo lugar, como única forma de educar." (BORDENAVE, 1987, p.14) $)^{11}$

\section{EM BUSCA DA FORMAÇÃO DO DISCURSO DA INDUSTRIALIZAÇÃO DO ENSINO NO BRASIL}

Como vimos acima, destacam-se no bojo do nosso corpus de análise duas materialidades lingüístico-discursivas, representadas pelos textos de número 1 e 10. O T10, aliás, parece inaugurar uma espécie de discurso fundador que, a partir de então, passaria a nortear a política brasileira de educação a distância: "em relação à história de um país, os discursos fundadores são discursos que funcionam como

11 As iniciativas em EAD patrocinadas pelo Estado brasileiro iniciam-se, também, nesse período (PFROMM NETTO, 1976). Em 1910, dá-se a instalação de uma filmoteca no Museu Nacional do Rio de Janeiro que vai gerar um movimento de educadores e intelectuais em torno da utilização do cinema para fins morais e pedagógicos, originando "um intenso debate, em publicações da imprensa diária e em revistas especializadas de diversos setores sociais" (CATELLI, 2003, 2005) e acabando por influir na criação do Instituto Nacional do Cinema Educativo, nos anos 1930. Fundada em 1923, a Rádio Sociedade do Rio de Janeiro por sua vez lança-se ao desafio de trabalhar "pela cultura dos que vivem em nossa terra e pelo progresso do Brasil", transformando-se em emissora do Ministério da Educação e Saúde (atual Rádio MEC) na década seguinte, um ano antes de o Estado Novo criar o Serviço de Radiodifusão Educativa. 
referência básica no imaginário constitutivo desse país. E a nossa tarefa é então mostrar como é que eles se estabilizam como referência na construção da memória nacional." (ORLANDI, 1993b, p.7)

Mas o T10 não se encontra isolado, dividindo com outros discursos - também capitais - a pretensão em ocupar um lugar inaugural, ou mesmo, fundacional, cujo paradoxo é situar-se na história, embora negando-a. Em outras palavras, "na relação de sentido que um discurso fundacional estabelece com seu interdiscurso específico, um discurso que se auto-apresenta como fundacional, precisa produzir uma ilusão de corte ou ruptura com os processos de sentido sedimentados como memória discursiva." (ZOPPI-FONTANA, 1997, p.171-172) ${ }^{12}$.

Abordando um "complexo problema", por sinal, "jamais ventilado com igual extensão em nosso país, sequer em publicações técnicas", o T10 torna a educação e treinamento por correspondência "matéria particularmente importante para a administração de pessoal no Brasil, dadas a extensão do território nacional e as conhecidas deficiências de transporte com que lutamos." (PINTO, 1955, p.3-4) De sorte que restaria aos demais textos do nosso corpus, inclusive ao T1, reafirmar, amplificar e atualizar esse discurso a sua conjuntura sócio-histórica: "pretende-se ampliar as oportunidades de acesso à educação de grande número de estudantes que vivem em regiões distantes dos grandes centros urbanos do Brasil,

12 Como nosso corpus discursivo remonta à década de 1950, não estamos considerando (nem tampouco ignorando) outros potenciais discursos fundadores ou fundacionais que, antes disso, teriam norteado as iniciativas do Estado brasileiro em EAD, conforme sugerem, por exemplo, Pfromm Netto (1976), Federico (1982), Morettin (1995) e Catelli (2003, 2005). 
país privilegiado com dimensões continentais." (MOTA; CHAVES FILHO; CASSIANO, 2006, p.21)

No entanto, ao postular a democratização da educação superior e a formação inicial e continuada de professores, a Universidade Aberta do Brasil não apenas dá continuidade, como tende representar um marco histórico para a educação a distância no País. Razão pela qual partimos nossa análise da sdr 1 como sequência-modelo, na medida em que a consideramos exemplar para percorrer o sistema de enunciabilidade - ou melhor, o discurso da industrialização do ensino - que norteia a política nacional de educação a distância.

\section{"Marco histórico" da EAD}

Compreender um enunciado ou uma sequência discursiva de referência (sdr), esclarece Courtine (1981), implica determinar a pertinência histórica de sua conjuntura, a produção desta seqüência na circulação de formulações transportadas pelas sequências discursivas que se opõem, se respondem e se citam, visando descrever, finalmente, o marco institucional e as circunstâncias enunciativas desta produção. Logo de início, chama-nos a atenção o fato de que o T1 - "Universidade Aberta do Brasil: democratização do acesso à educação superior pela rede pública de educação a distância" - enfatiza a capacidade da SEED em articular a política educativa e o sistema de ensino, com o propósito de promover a utilização intensiva das tecnologias de informação e comunicação no contex to escolar, buscando inovações tecnológicas e metodológicas para a melhoria da qualidade da educação no país.

Ao longo do texto, percebemos que os enunciados utilização intensiva das tecnologias de informação e comunicação, 
inovações tecnológicas e metodológicas e melhoria da qualidade da educação no país - que, de forma incisiva, apresentam-se investidos do discurso da industrialização do ensino - serão retomados constantemente, com apoio de paráfrases, metáforas e metonímias. A análise que esboçamos a seguir tenta dar conta, essencialmente, de como essa enunciabilidade é produzida, difundida e impulsionada a circular ou assumir uma permanente e sistemática circularidade e quais são as suas implicações discursivas e não discursivas.

A situação de enunciação em torno da UAB

A situação de enunciação que engendra o T1, apesar de não referenciada na sdr 1, tem lugar na Secretaria de Educação a Distância do MEC, conforme encontramos repetido às notas de rodapé, constantes da página inicial daquele texto. Como referenda a folha de rosto do livro "Desafios da educação a distância na formação de professores", onde o T1 é publicado, essa produção se dá em Brasília-DF, de onde emana grande parte do discurso pronunciado pelo Governo Federal.

Embora a sdr 1 reporte-se ao ano de 2005, passando a impressão de ter sido produzida nesse período ( o ano de 2005 representará), encontramos somente ao final do texto um tempo, ou melhor, uma data que, tudo indica, deve-se aproximar do período de sua elaboração: 13 de abril de 2006, cujo ano coincide com aquele também referendado na folha de rosto daquela publicação. Mais adiante, quando analisarmos o texto como acontecimento discursivo, perceberemos a importância desse período para a produção do discurso oficial, assim como para sua difusão e circulação. 
Mesmo fato acontece aos sujeitos e ao quadro institucional em que se inscreve o discurso - vamos encontrar suas indicações em outros lugares textuais. Logo à capa da coletânea "Desafios da educação a distância na formação de professores", percebemos que o T1 foi produzido sob os auspícios da SEED, órgão subordinado ao Ministério da Educação do Governo Federal, cujo slogan observamos ali estampado: "Brasil: um país de todos"13. Como se o país fosse território de todos os brasileiros e, ao mesmo tempo, o governo representasse plenamente o povo: "Governo e povo são emparelhados como iguais e correspondentes, criando de novo a ilusão da democracia, equivalência e igualdade." (ROMÃO; ROMÃO, 2005)

O lugar social e a posição de sujeito estão definidos, por sua vez, na abertura do T1. Logo abaixo do título e subtítulo, encontramos declinados os nomes dos três autores e, em notas de rodapé, os respectivos lugares e cargos que ocupam: Professor Titular da Universidade Federal de Santa Maria - RS, Doutor em Física e, atualmente, ocupa o cargo de Secretário de Educação a Distância do MEC; Engenheiro Eletricista, Licenciado em Física e Doutorando em Educação. Diretor de Políticas em Educação a Distância da Secretaria de Educação a Distância do MEC; Bacharel e Licenciado em Física, Mestre em Educação, Coordenador-Geral de Articulação

13 “Todos os slogans podem ser classificados como autoritários, justamente por não oferecerem aos seus interlocutores a possibilidade da reversibilidade nos papéis da interlocução, muito embora alguns deles simulem um efeito de dialogismo ao evocarem o interlocutor na materialidade discursiva. Contudo, esse destinatário não é especificado, é indiferenciado, pode ser um eleitor em separado e/ou o conjunto dos eleitores de uma cidade, de um estado, de um país, entre outros." (BARONAS, 2000, p.80) 
Institucional em Educação a Distância da Secretaria de Educação a Distância do MEC.

Ainda que, hierarquicamente, tenhamos representadas aí as figuras do chefe e assessores, não foi qualquer um destes últimos que compôs a equipe de autores. Conforme veremos de forma detalhada a partir da análise das regularidades e continuidades discursivas da sdr 1, a SEED, as políticas (projetos e programas) em EAD e a articulação institucional aparecem entre os enunciados mais recorrentes e que produzem os principais efeitos de sentido.

Por outro lado, textualmente a sdr 1 não faz referência a um destinatário concreto ou específico. Ele é evocado, no entanto, por intermédio de estratégias discursivas. Quando os autores elencam uma série de instâncias que representam os parceiros de projetos da SEED, acabam tendo como horizonte de seu discurso esses mesmos parceiros. Entre instituições objetivas, reportam-se eles às demais secretarias e órgãos do MEC, instituições de educação superior, Secretarias Estaduais de Educação, demais Secretarias do MEC, Fórum das Estatais pela Educação, instituições federais de educação superior, Estados e Municípios. Entre as referências vagas, encontramos os sistemas de ensino, as redes de colaboração, os novos e diferenciados partícipes e as três esferas governamentais. Concorre para essa evocação, como demonstraremos adiante, o fato de a parceria representar uma regularidade discursiva cara àquela sequência.

Acrescentaremos a esses parceiros uma série de outros destinatários que inclui desde o público-alvo mais importante ao sujeito do discurso - "alunos, professores e gestores de escolas públicas de ensino fundamental, médio e de instituições públicas de ensino superior" (BRASIL, 2006g), até pesquisadores, especialistas, técnicos e 
potenciais leitores interessados em EAD. De uma forma ou de outra, nosso locutor acaba construindo seu texto a partir das relações discursivas que pode estabelecer com o seu receptor potencial ou eventual: "seu texto é de alguma maneira 'composto sob medida' e reflete a imagem que ele tem do destinatário através dos discursos que lhe faz e da maneira como se dirige a ele." (FORGET, 1994, p.67) Não estivessem pensando em um amplo universo de destinatários, os autores não sentiriam a necessidade de agregar a um discurso predominantemente autoritário um texto de natureza didática que atravessa quase todo o T1, conforme veremos no decorrer da nossa análise.

Vozes e silêncios que calam e falam sobre a $U A B$

À medida que são evocados como destinatários, os parceiros da SEED acabam sendo negligenciados como sujeitos da história, ou melhor, ficam relegados à condição de sujeito silenciado. Apesar das referências a potenciais instâncias de interlocução, incluindo desde os sistemas de ensino, passando pelas instituições de educação superior e indo até as três esferas governamentais, não encontramos na sdr 1 indícios de polifonia, enquanto os vestígios de polissemia apresentam-se reduzidos. Muito mais em se tratando de um discurso de natureza oficial, falar da política de EAD/SEED/Projeto UAB pressupõe o domínio, também, de uma política do silêncio que "se define pelo fato de que ao dizer algo apagamos necessariamente outros sentidos possíveis, mas indesejáveis, em uma situação discursiva dada." (ORLANDI, 1997, p.75)

Ao longo do T1, essa situação também não sofre maiores alterações, até porque a maioria das instâncias de enunciação evocadas remete à esfera do Governo Federal, 
configurando um discurso oficial por excelência. Ainda assim, a ênfase do texto é dispensada aos órgãos e programas na área de educação: $M E C, S E E D$, INEP, Fórum das Estatais pela Educação, Plano Nacional de Educação, Projeto $U A B$. Ademais, os autores baseiam-se o tempo todo em marcos regulatórios, cuja essência é ditar o que se deve fazer - Constituição Federal, Lei de Diretrizes e Bases da Educação e respectivas regulamentações para $E A D$, destacando-se o Edital de Convocação, isto é, o Edital no 1 da SEED, de 16/12/2005, que trata da Chamada Pública para seleção de pólos municipais de apoio presencial e de cursos superiores de educação a distância.

Muito embora relacione ao final uma série de onze Referências Bibliográficas sem evocá-las uma única vez ao longo do texto, à exceção da referência implícita Diálogo para a cidadania e inclusão - Texto-Base do Fórum das Estatais pela Educação e do documento explícito Projeto Universidade Aberta do Brasil, somente encontramos vestígios dessa bibliografia quando cotejamos seus enunciados àqueles que marcam seja a sdr 1 seja o T1 no seu conjunto: Educação a Distância no Brasil; Diálogo para a Cidadania e inclusão; Novas Tecnologias e Mediação Pedagógica; Hipertexto, fechamento e o uso de não-linearidade discursiva; Universidade Aberta do Ministério da Educação e Cultura; Sala de aula interativa.

Esse ocultamento ou silenciamento da fala do outro, contudo, não se dá de forma aleatória. Ele tem um funcionamento próprio que depende, sobremaneira, das posições que os locutores ocupam no texto, (pre)tendendo preencher todos os papéis passíveis ao sujeito e os silêncios possíveis ao próprio discurso. Se o "vazio" da linguagem não representa uma espécie de falta, mas de horizonte ou de "incompletude constitutiva da linguagem", o silêncio 
funciona então como fundamento essencial à polissemia: "mais se diz, mais o silêncio se instala, mais os sentidos se tornam possíveis e mais se tem ainda a dizer." (ORLANDI, 1997, p.71) Se tentar tomar a palavra e ocupar o silêncio até as últimas conseqüências pode ser impossível ou redundar em contradição, não deixa de evidenciar o emprego de uma estratégia discursiva.

Num primeiro momento, percebemos que os autores do T1 ocupam a posição de um sujeito determinado, ainda que implícito na desinência verbal ou no pronome oblíquo átono. Além da fácil determinação do seu nome e da posição que ocupa, como vimos acima, temos um sujeito que faz questão de se situar no discurso, não apenas face ao próprio texto e ao objeto discursivo, bem como face a si mesmo e ao seu (potencial) interlocutor. Mesmo que no meio da seqüência decida tomar uma posição de afastamento, situando-se como sujeito indeterminado expresso pela forma do verbo - propor modelo alternativo, o sujeito discursivo assume a palavra como "sua" reiteradamente.

No início da sdr 1, coloca-se ele por duas vezes, repetindo o verbo poder de forma diferente, embora a forma negativa empregada - Não poderíamos - não altera o propósito de imprimir um efeito de positividade - podemos. No final da seqüência, os locutores situam-se ainda mais incisivamente face ao discurso que produzem - nos colocando, assumindo sua autoria como já determinada em um tempo passado - elaboramos, quer dizer, no pretérito perfeito do indicativo que refere um acontecimento já ocorrido ou concluído e que, numa primeira instância, está posto e não permite mais ser alterado.

Num segundo momento, os autores assumem a posição de um sujeito competente (CHAUI, 1981) que não se contenta apenas em se colocar no discurso, mas faz 
questão de acentuar sua competência como sujeito falante. Em vários momentos, reitera ele o fato de não se encontrar ali por acaso, mas porque domina o objeto discursivo eficientemente. Mesmo a sdr 1 tendo a função de introduzir parcialmente o T1, ressalta aquele sujeito o cuidado que tem em não negligenciar o que goza realmente de importância - Não poderíamos deixar de citar - e de assumir com segurança suas posições ou convicções - podemos afirmar. Acentua ele, inclusive, não temer qualquer questionamento - nos colocando abertos ao diálogo, até porque não fora qualquer um que recebeu a incumbência ou fora convidado a escrever aquele texto. Conhecendo e concebendo o Projeto UAB como conhecem/concebem, ao afirmar elaboramos este artigo, é como se aqueles autores reafirmassem sempre que nós - e mais ninguém - é que fomos capazes de elaborar este artigo.

Num terceiro momento, os autores exercem a posição de um sujeito autorizado, capaz não só de falar com a devida competência sobre o objeto, assim como de representar no discurso a autoridade investida no cargo que ocupa. Em princípio, não é preciso ser diretor do Departamento de Políticas em EAD nem coordenador geral de Articulação Institucional em EAD da SEED para falar de seus programas; porém, se assim o for, mais credibilidade o discurso assumirá: Não poderíamos deixar de citar os programas TV Escola e Proinfo; Projeto Universidade Aberta do Brasil; Sistema Universidade Aberta do Brasil. Do mesmo modo, não é necessário ser secretário da SEED para enfatizar seus êxitos; porém, se assim o for, mais peso o discurso ganhará: a SEED consolidou-se como referência internacional na área de educação a distância e de tecnologias educacionais; podemos afirmar seu caráter estratégico para a educação brasileira; Grande parte do sucesso alcançado pela SEED. 
Como gostariam de dizer aqueles autores, elaboramos este artigo porque, independentemente de termos sido incumbidos ou convidados, estamos já-autorizados a gozar do direito pleno de falar pelo (tal como) quadro ideológico-institucional que representamos. Considerando, além disso, que esse quadro (SEED/MEC/Governo Federal) se inscreve em um governo eleito nas urnas em 2002, através de uma coligação de centro-esquerda (PT, PL, PCB, PC do B e PMN) que obtém quase 53 milhões de votos ou dois terços dos votos válidos, em uma conjuntura democrática de inícios do século XXI, poderíamos acrescentar que os locutores assumem, também, uma posição de sujeito legitimado. Um sujeito a quem se atribui não apenas o dever, mas o direito de falar em nome do Estado brasileiro, mais particularmente, de sua política nacional de educação a distância, incluindo seu órgão gestor (SEED) e as ações por ele conduzidas, dentre as quais o Sistema UAB.

A possibilidade de um sujeito legitimado ajuda-nos a entender porque, ao justificar o Projeto $\mathrm{UAB}$, os autores do T1 carregam em metáforas e metonímias, retomando e dimensionando enunciados da sdr 1 de forma ampla, categórica e contundente: $o$ Projeto $U A B$ representa mais que um programa governamental, configura-se como programa de nação; educação superior para todos, com qualidade e democracia; desafio permanente para construção de um projeto nacional sustentável e inclusivo.

UAB como estratégia dialógica

Esse desvendamento do jogo discursivo que estabelece a ênfase sobre a voz do eu e o ocultamento ou silenciamento do outro nos permite caracterizar o discurso que prepondera na sdr 1 e, por extensão, no T1 como um todo. 
Assim como os demais textos da coletânea "Desafios da educação a distância na formação de professores", o T1 segue inicialmente como gênero os moldes de um artigo de natureza acadêmica, com introdução, desenvolvimento, conclusão e referências bibliográficas, conforme fazem questão de anunciar seus autores na própria sdr 1 : elaboramos este artigo com o objetivo de apresentar o Projeto Universidade Aberta do Brasil.

Por isso mesmo, não esquecem eles de empregar elementos de ordem científica que tendem atribuir maior confiabilidade e credibilidade ao texto, como algumas definições destacadas em notas de rodapé: Conjunto de tecnologias apropriadas para coleta, armazenagem...; Educação ou formação continuada ao longo da vida é um conceito...; a contextualização do objeto: Introdução 4 Alguns dados sobre oferta e atendimento na educação superior brasileira 4 Alguns dados sobre docentes e formação docente no Brasil 4 O Projeto UAB no Fórum das Estatais pela Educação 4 O Projeto-Piloto com o Banco do Brasil 4 O Edital de Convocação 4 Projetos encaminhados para avaliação; e a recorrência a documentos, bases de dados, gráficos, tabelas e uma gama de dados estatísticos atualizados. O uso de recursos acadêmico-científicos acaba contribuindo para o T1 incorporar um tipo de linguagem fortemente didática. A sua utilização pressupõe que o destinatário não sabe nada sobre o objeto; conhece o objeto de forma apenas superficial; encontra-se desatualizado sobre suas tendências e perspectivas; ou mesmo, precisa ser esclarecido sobre suas dimensões e conseqüências.

$\mathrm{Na}$ própria sdr 1, até por seu caráter introdutório, os autores tentam orientar e facilitar a leitura o máximo possível. Em tom professoral, pontua o sujeito do discurso que a história da Secretaria de Educação a Distância tem início em 1995, quando foi criada no âmbito do Ministério da 
Educação, deixando a sugestão, portanto, de que o órgão origina-se e se mantém vinculado à esfera do Governo Federal. Desde sua criação, acrescenta ele, a SEED (sigla que é reiterada, pois, além de ajudar o texto a se tornar conciso, contribui para a incorporação de uma memória discursiva à instituição) tem atuado, quer dizer, tem permanecido fiel à atuação inicial, com o propósito muito claro de promover a utilização intensiva das tecnologias de informação e comunicação no contexto escolar.

Ressalta o sujeito do discurso, ainda, que o sucesso alcançado pela SEED (síntese de sua condição de referência internacional em EAD e de seu caráter estratégico para a educação brasileira), nesses dez anos de vida (o que reforça a idéia de que a instituição tem uma história importante a ser resgatada), deve-se em Grande parte a uma estratégia também bastante objetiva: trabalho colaborativo com os parceiros de projetos que são reiteradamente arrolados. Sequenciando essa trajetória de sucesso da SEED, chama atenção aquele sujeito que $o$ ano de 2005 representará um marco histórico para a educação a distância no País, não esquecendo de incorporar ao discurso um caráter heróico-narrativo, típico de texto didático-literário.

O acontecimento responsável por esse marco histórico, salienta o sujeito do discurso, é a criação do Projeto Universidade Aberta do Brasil, um nome pomposo que segue uma denominação empregada em todo o mundo (Universidade Aberta) para dar conta de um projeto ambicioso, sobretudo, em países continentais como o Brasil. Além da sigla acrescentada logo em seguida (“UAB”), o Projeto UAB ganha duas variações nominais - rede nacional de educação a distância e Sistema Universidade Aberta do Brasil. Esta última, inclusive, é enfatizada - a qual estamos denominando Sistema Universidade Aberta do Brasil, empregando-se assim um recurso que, ao invés de confundir, 
torna-se uma estratégia retórica para reter o objeto na memória discursiva. Aliás, apesar de sua importância já ressaltada, não é a SEED nem outros programas por ela conduzidos que se situam como eixo central do texto produzido: elaboramos este artigo com o objetivo de apresentar o Projeto Universidade Aberta do Brasil (ainda que este mantenha relação intrínseca com aquela Secretaria).

A intenção declarada de apresentar o Projeto UAB presente no enunciado acima evidencia que, associada a uma linguagem didática, porém com repercussões bem mais amplas quando consideramos o campo conflituoso da política, sobressai na sdr 1 uma estratégia discursiva que se revela importante ao discurso oficial - uma estratégia, recorrentemente, de natureza dialógica (BAKHTIN, 1988, 1992, 1997). Num primeiro momento, essa estratégia parece propor a idéia de uma heterogeneidade discursiva, a qual pressupõe o caráter quase nunca homogêneo do próprio texto que, além de acionar tipos diversos de seqüências textuais, gêneros etc., ver-se perpassado por discursos provenientes de outras fontes enunciativas.

Num segundo momento, a estratégia dialógica busca provocar repercussões junto ao próprio campo discursivo. Ao afirmar elaboramos este artigo com o objetivo de apresentar, deixa-se transparecer que não se trata de impor o Projeto $\mathrm{UAB}$, mas de apenas e tão somente apresentá-lo aos seus potenciais parceiros, o que pressupõe colocá-lo em circulação e discussão permanente. Como costuma fazer parte da atitude dialógica assumir uma condição de humildade e de respeito perante o outro, não perde a oportunidade o sujeito do discurso de se resguardar como sujeito cognitivo. Dizer Sem a pretensão de esgotar revela um sujeito despretensioso com qualquer possibilidade de dar conta do objeto em sua plenitude, admitindo não só sua incapacidade de onisciência, assim como a própria incompletude 
do discurso. Como estratégia discursiva acrescenta, ainda, sempre nos colocando abertos ao diálogo, assinalando que a atitude dialógica não é de agora e representa uma regularidade - sempre; além de demonstrar que se trata de assumir, em que pese os riscos, uma postura política e ética nem sempre adotada - abertos ao diálogo.

A estratégia dialógica presente na sdr 1 , num terceiro momento, pretende exercer influência além do âmbito discursivo. Depois de nomear e reconhecer o papel importante de uma série de instâncias - em destaque as instituições de educação superior, as Secretarias Estaduais de Educação e as demais Secretarias do $M E C$, prefere o locutor tratar o outro como igual e de forma íntima, como parceiros de projetos, redes de colaboração, novos e diferenciados partícipes. A referência vaga, porém abrangente aos diversos parceiros, que permite não excluir ou não negligenciar nenhum deles, torna-se útil mais ainda para reforçar a adesão e mobilização em torno do Sistema UAB.

Converge o discurso, por isso mesmo, para uma ênfase sobre a co-responsabilidade do outro. Assim como acontecera à SEED, a participação efetiva dos antigos, novos e diferenciados parceiros revela-se de fundamental importância para o sucesso da UAB. Como reitera insistentemente o sujeito do discurso, não há como pensar em um sistema concebido como tal sem a intensa articulação, o trabalho colaborativo, a estreita relação, a união de esforços entre todos e, de modo especial, entre as três esferas governamentais. Muito mais do que uma convocatória ao voluntariado, a estratégia dialógica apela para uma espécie de discurso do comprometimento que (re)clama às instituições aderir ao Projeto UAB, sob pena não só de perder o rumo da história, como também de descumprir sua missão social; como se boa parte delas - para não dizer, o seu conjunto 
- já não tivesse que fazê-lo por força de obrigação institucional, ou mesmo, dependência econômico-financeira.

O que não deixa de significar um processo de interpelação (ALTHUSSER, 1992), mediante o qual, além de "interpelar" a si próprio por intermédio dos autores do texto, o sujeito do discurso interpela o outro, representado naquelas instituições, a conceber como natural aquilo que é fruto de assujeitamento. Fato este que nos ajuda a compreender como a ideologia "recruta" seus sujeitos, ou melhor, como os indivíduos de modo geral "recebem como evidente o sentido do que ouvem e dizem, lêem ou escrevem (do que eles querem e do que se quer lhes dizer), enquanto 'sujeitos-falantes'." (PÊCHEUX, 1988, p. 158) De todo modo, na conjuntura contemporânea, a estratégia dialógica acaba se revelando importante para relativizar ou escamotear um discurso que, no fundo, configura-se como predominantemente autoritário.

\section{Um discurso predominantemente autoritário}

Seguindo a concepção de Orlandi (1996a), para dar conta do tipo de discurso que atravessa a sdr 1 poderíamos empregar critérios de diversas ordens. A começar por critérios presos a normas institucionais, o que nos permitiria reduzir a análise à tipologia do discurso governamental. Além das inúmeras marcas textuais que apontam nessa direção (MEC, SEED, Programas TV Escola e Proinfo, $U A B$ etc.), o enunciado elaboramos este artigo com o objetivo de apresentar o Projeto Universidade Aberta do Brasil, dificilmente, seria pronunciado por outra instância que não a do Governo Federal. Não caberia ao discurso jornalístico ou jurídico, por exemplo, apresentar o Projeto UAB, mas analisar, discutir ou questionar as suas implicações, com o 
mínimo de rigor, objetividade e imparcialidade, critérios normalmente atribuídos a essas instâncias.

Poderíamos optar, por outro lado, por critérios vinculados a domínios de conhecimento que apontariam para um discurso de natureza acadêmico-científica. Uma tipologia que já assinalamos como recorrente na sdr 1, por força da caracterização do gênero textual como artigo e do uso de uma linguagem didática, mas que não nos possibilita ainda apreender a essência do discurso. O que observamos é que os locutores se apropriam do discurso científico, marcado tradicionalmente por critérios de credibilidade que superam o discurso governamental, a partir de um lugar social que remete à academia (Professor...), porém de uma posição de sujeito marcadamente institucionalizada (Secretário...).

Haveria a possibilidade, ainda, de adotarmos como parâmetro critérios formais ou estruturais, concebendo o discurso como uma dissertação que não deixa de empregar recursos da narração - Desde sua criação em 1995 - e da descrição, tais como, parceiros de projetos, em destaque as instituições de educação superior, as Secretarias Estaduais de Educação e as demais Secretarias do MEC. Além de podermos considerar que a própria sdr 1 estrutura-se na forma tradicional da seqüência introdução (apresentação do tema-objeto: Projeto UAB), desenvolvimento (discussão de suas implicações: importância na consolidação do Sistema Universidade Aberta do Brasil) e conclusão (considerações finais ou inferências: marco histórico para a educação a distância no País), percebemos que a dissertação aí empregada é mais de ordem argumentativa do que expositiva. Acentuando, por exemplo, em podemos afirmar seu [SEED] caráter estratégico para a educação brasileira, os locutores não deixam de induzir seus parceiros a assumir tal afirmação 
igualmente como sua, com maiores chances, portanto, de espelhar a verdade.

Em contrapartida, do mesmo modo que Orlandi (1996a, p.152), preferimos adotar uma tipologia capaz de "incorporar a relação da linguagem com suas condições de produção." No estabelecimento dessa tipologia ganham importância as características da interação e da polissemia, derivando da primeira o critério de reversibilidade que determina a dinâmica da troca de papéis entre os sujeitos da enunciação e, da segunda, o critério da relação desses sujeitos com o objeto discursivo. Considerando, então, o que define aquela autora como tipos de discurso, não encontramos na sdr 1 marcas de um discurso lúdico (em que a reversibilidade é total e a polissemia não tem limites) nem consideravelmente de um discurso polêmico (em que a polissemia se apresenta controlada e a reversibilidade ocorre sob certas condições), mas a predominância de um discurso autoritário.

O que percebemos, na verdade, é que tanto a sdr 1 como o T1 no seu conjunto estão assentados em um discurso autoritário, caracterizado pelo fato de que "a reversibilidade tende a zero, estando o objeto do discurso oculto pelo dizer, havendo um agente exclusivo do discurso e a polissemia contida." (ORLANDI, 1996a, p.154) Um discurso, por assim dizer, que visa a assimetria de cima para baixo, é estratégico e pretende impor discursivamente a verdade, cuja tradução parece se manifestar no seguinte enunciado categórico: o ano de 2005 representará um marco histórico para a educação a distância no País.

Mesmo utilizando uma estratégia dialógica que prega a aproximação aos diferenciados partícipes, o sujeito do discurso atribui-se de antemão uma humildade e uma capacidade inata que, ao tempo que sugerem, tendem a inibir 
a possibilidade de interlocução. Vejamos: Sem a pretensão de esgotar a complexidade e riqueza intrínsecas à temática em questão, e sempre nos colocando abertos ao diálogo. Indicando o fragmento Sem a pretensão de esgotar a complexidade e riqueza que, se já não é possível aos próprios locutores dar conta do objeto discursivo, a partir dos lugares sociais e das posições privilegiadas que ocupam, pouca contribuição restará a ser dispensada por parte do outro.

$\mathrm{O}$ advérbio sempre indica, por sua vez, que, como o que se afirma textualmente já é fruto de um diálogo contínuo, não há razões para debate nem questionamento. Até porque seriam consistentes os fatos reportados: seu caráter estratégico para a educação brasileira; Grande parte do sucesso alcançado pela SEED nesses dez anos de vida, se deve à estratégia de trabalho colaborativo; sua importância na consolidação da rede nacional de educação a distância; em estreita relação com os Estados e Municípios; cristalizando a união de esforços das três esferas governamentais.

Enquanto o discurso lúdico tende a representar o extremo da polissemia e o discurso polêmico o equilíbrio entre esta e a paráfrase, a tendência do discurso autoritário é reproduzir o processo parafrástico, fazendo permanecer o mesmo sentido, ainda que nas formas as mais diversas possíveis (ORLANDI, 1996a, p.155). Os dois segmentos que introduzem a sdr 1 e o próprio T1 são exemplares nesse sentido, principalmente, quando os consideramos como constituídos da seguinte forma:

- a Secretaria de Educação a Distância (SEED) do Ministério da Educação tem atuado transversalmente às demais secretarias e órgãos do $M E C$ não é a mesma coisa que em intensa articulação com os sistemas de ensino; porém, a Secretaria de Educação a Distância 
(SEED) do Ministério da Educação tem atuado transversalmente às demais secretarias e órgãos do $M E C$, bem como em intensa articulação com os sistemas de ensino se completa, na medida em que atuado transversalmente pressupõe intensa articulação e vice-versa, ao passo que sistemas de ensino não deixam de evocar secretarias e órgãos do MEC e vice-versa.

- os programas TV Escola e Proinfo que constituem dois importantes pilares, também, não podem ser confundidos com a SEED consolidou-se como referência internacional na área de educação a distância e de tecnologias educacionais; contudo, os programas TV Escola e Proinfo [...] constituem dois importantes pilares sobre os quais a SEED consolidou-se como referência internacional na área de educação a distância e de tecnologias educacionais se completa, à medida que os programas TV Escola e Proinfo e a SEED estão visceralmente associados, do mesmo modo que importantes pilares e referência internacional traduzem paráfrases que tanto podem se aplicar àqueles programas como à SEED.

Claro que não se pode entender o discurso do Estado brasileiro sem levar em conta o emaranhado e as contradições surgidas no seu interior. Exemplo disso é que, até 1979, o discurso do Regime Militar apresenta-se fortemente monológico, reconhecendo apenas os discursos referentes à mesma formação ideológica. Apesar do autoritarismo ainda se manifestar nos inícios da década de 1980, os discursos vão comportar modificações substanciais, revelando-se o discurso oficial muitas vezes contraditório e perdendo seu caráter homogêneo para o discurso oposicionista (FORGET, 1994, p.168). O discurso 
predominantemente autoritário compreende uma regularidade discursiva presente na própria sdr 1 e, por extensão, a predominância de fragmentos da industrialização do ensino não somente aí, assim como ao longo do T1 e do conjunto do discurso que norteia a política nacional de educação a distância.

\section{As regularidades discursivas da $U A B$}

Analisando a sdr 1 do ponto de vista do par regularidade/descontinuidade do discurso, vamos perceber que o sujeito do discurso repete uma série de marcas ou propriedades textuais, ao longo de toda a seqüência. Esses elementos demarcam o texto não apenas de maneira formal, como também discursiva, ordenando o funcionamento do discurso a partir de um conjunto de fragmentos e enunciados que, basicamente, referem-se a cinco temas ou objetos: TICs/EAD, SEED/MEC, UAB, parceria e, por último, democratização e qualidade da educação. Sob o domínio de famílias parafrásticas, o discurso autoritário tenta produzir efeitos de sentido, ditando o que interessa e é prioritário saber a respeito da Universidade Aberta do Brasil.

Acompanhando a distribuição dos fragmentos e enunciados através dos parágrafos ou segmentos que compõem a sdr 1 (1, 2 e 3), podemos melhor observar como esse discurso se organiza. Importa entendermos antes de tudo, insistem os locutores, que a UAB reflete o primado da (1) utilização intensiva das tecnologias de informação e comunicação (TICs, nomenclatura usualmente adotada na literatura internacional) na sociedade contemporânea e, particularmente, no contexto da escola. Promover tais tecnologias implica nada mais do que fomentar (1) inovações 
tecnológicas e metodológicas, já experimentadas e aprovadas lá fora, imprescindíveis também à educação nacional. Sobretudo à (1) educação a distância - (2) educação a distância - (3) educação a distância (reiteração esta que reforça a nossa memorização e própria opção pela modalidade de $E A D$, como vai ser nomeada no restante do T1), onde as (1) tecnologias educacionais (denominação mais antiga) e os conteúdos multimídia (nome atualizado dos produtos tecnológicos, às vezes, usados como sinônimos de TICs) são empregados de modo especial.

Dessa forma, salientam aqueles locutores, a UAB não surge do acaso, mas inserida no bojo da política nacional de EAD, capitaneada de modo exemplar pela (1) Secretaria de Educação a Distância (SEED) do Ministério da Educação. Depois de vermos, durante dez anos, aquela Secretaria ter atuado transversalmente e em intensa articulação com as diversas instâncias governamentais e não governamentais, não há como não concordar com o (2) sucesso alcançado pela SEED. Estão a nos provar isso o seu caráter estratégico para a educação brasileira, principalmente, em tempos de globalização, e o incomensurável fato de que a SEED consolidou-se como referência internacional, justo num momento em que o Brasil desponta no cenário da geopolítica mundial. Sendo objeto de reiteração que também não é aleatória - (1) SEED - SEED - (2) SEED, a Secretaria não aparece no terceiro parágrafo da sdr 1 , posto que é substituída aí pela própria $\mathrm{UAB}$.

Em princípio, fazem questão de acentuar os locutores, devemos conceber a UAB como mais um dentre tantos (1) projetos e programas, programas e (2) projetos conduzidos pela SEED, o que, mais uma vez, reforça o seu trabalho amplo, sistemático e diligente. Com ênfase para os (1) programas TV Escola e Proinfo, cujos impactos junto ao 
ensino fundamental e médio são conhecidos, responsáveis por criar as linhas mestras de nossa atuação exitosa em nível nacional e mundial. Semelhantemente, precisamos vislumbrar que o (2) Projeto Universidade Aberta do Brasil (UAB) - (3) Projeto Universidade Aberta do Brasil (desta feita, é a UAB que deixa de ser reiterada no primeiro parágrafo, sendo ali representada mediante a SEED), também, tem pretensões ambiciosas. Além de tornar realidade nossa (3) rede nacional de educação a distância, capaz portanto de levar educação superior a todos os rincões do país, o Sistema Universidade Aberta do Brasil atualiza-nos em relação ao que há de mais avançado no mundo em termos de educação, a saber, a universidade virtual e global.

A idéia de rede e de Sistema, explicam aqueles locutores, pressupõe situarmos a UAB como resultante de uma parceria permanente e sistemática. Parceria esta que se apóia na experiência de uma década de (1) intensa articulação e (2) estratégia de trabalho colaborativo da SEED (o que reforça o seu papel estratégico em nível nacional e mundial) com os diversos parceiros de projetos, quer dizer, com membros de uma sociedade ou comunidade cujos interesses são comuns. Destacando-se entre eles as (1) demais secretarias e órgãos do MEC, os sistemas de ensino, o contexto escolar, (2) as instituições de educação superior, as Secretarias Estaduais de Educação e [para não esquecermos] as demais Secretarias do MEC.

Além de herdar essas antigas redes, acrescentam os locutores, a UAB vem mobilizar (2) novas redes de colaboração. Contribuirá nesse sentido, de forma também substancial, a (3) estreita relação (sinônimo de intensa articulação) e união de esforços (paráfrase de estratégia de trabalho colaborativo) que estabeleceremos com outras instâncias de cooperação. Entre os (2) novos e diferenciados partícipes 
- que, aí, substituem os parceiros de projetos, precisamos salientar o papel do (3) Fórum das Estatais pela Educação que, em parte, assume o lugar reservado às demais secretarias e órgãos do MEC; das instituições federais de educação superior que evocam as instituições de educação superior, com ênfase para aquelas vinculadas à esfera federal; dos Estados e Municípios, o que retoma, mas vai além das Secretarias Estaduais de Educação; das três esferas governamentais - SEED/MEC e, para não esquecermos, Estados e Municípios; enfim, da nossa educação superior pública como um todo.

Nesse sentido, completam aqueles locutores, a UAB objetiva garantir, acima de tudo, a democratização e a qualidade da educação. A (1) melhoria da qualidade da educação no país, uma das metas essenciais do governo Lula ${ }^{14}$, confunde-se, obrigatoriamente, com a necessidade de adotarmos uma política de EAD que, assentada em importantes pilares (antes com os programas TV Escola e Proinfo, hoje com o Projeto Universidade Aberta do Brasil), consolide-se como referência internacional (assim como a SEED) e assuma caráter estratégico para a educação brasileira, acrescentando-se a

14 "Os programas governamentais destinados a aumentar o número de universitários no Brasil são responsáveis por uma 'pequena revolução' no sistema educacional, disse hoje (17) o presidente Luiz Inácio Lula da Silva. Ele destacou, em seu programa semanal de rádio Café com o Presidente, os programas de concessão de bolsas de estudo e de reestruturação das universidades federais [...] O ensino de base foi outro tema do programa [...] 'Nós não podemos esquecer que no ano passado nós lançamos o Plano de Desenvolvimento da Educação - o PDE. Esse plano estabeleceu 40 ações que vão desde a construção de creches até as bolsas de pós-doutorado. Mas a ênfase do programa é a qualidade da educação básica', disse." (BRASIL, 2008a) 
este uma estratégia de trabalho colaborativo. Além de (2) inovar (o que evoca as inovações tecnológicas e metodológicas, ainda que não se reduza a estas) nossa educação como um todo, representa a UAB, especialmente, um marco histórico para a educação a distância no País, reforçando assim o sucesso alcançado pela SEED nesses dez anos de vida.

Sem precedentes em nossa história, não há como pensar em outro (2) modelo alternativo para a oferta e gestão de educação superior - alternativo ao modelo de educação presencial, inclusive, a partir da utilização intensiva das tecnologias de informação e comunicação - que não na plena (3) consolidação da rede nacional de educação a distância que, por seu turno, logo remete a uma teia enredada de parceiros de projetos, em intensa articulação, trabalho colaborativo, estreita relação e união de esforços pelo bem comum. Não restando dúvida, portanto, de que o Sistema Universidade Aberta do Brasil, nome mais preciso para representar o processo de descentralização ensejado pelo Projeto UAB, em outras palavras, rede nacional de educação a distância, constitui um passo decisivo para a nossa tão sonhada democratização do acesso à educação superior pública, gratuita e de qualidade. $\mathrm{O}$ que reitera, enfim, a melhoria da qualidade da educação no país e o modelo alternativo para a oferta e gestão de educação superior.

Esse mapeamento do dizer que marca a regularidade discursiva, afetando, de maneira especial, o contexto imediato da sdr 1, é bastante revelador, porém não dá conta plenamente das condições de produção, difusão e circulação que engendram e transcendem tal seqüência. Sobretudo aquelas que permitem determinados enunciados reproduzirem-se ao longo e na plenitude do discurso que norteia a política nacional de educação a distância. As mesmas condições que apontam na direção de um sistema 
de enunciabilidade que, a um só tempo, preside e atravessa desde os discursos relativos à SEED até aqueles que dizem respeito diretamente à $U A B$.

\section{UAB como acontecimento discursivo}

Objetivando desvendar a transcendência do discurso, compreendemos então a sdr 1 como configurando uma seqüência de três acontecimentos discursivos que contribuem para o discurso oficial instaurar uma circularidade. Apesar de nos depararmos, num primeiro momento, com um acontecimento que antecede os demais, não se trata de estabelecer a partir daí uma relação necessariamente linear de causa e efeito, mas de interdependência entre as situações de enunciação que vão se sucedendo e gerando novos acontecimentos discursivos. Dessa forma, concebemos o acontecimento 1 como sendo, principalmente, de produção do discurso, ainda que a sua emergência não seja de base fundadora deste.

Em primeiro lugar, convém ressaltarmos que a sdr 1 não foi escrita aleatoriamente, mas para fazer a abertura da Introdução do T1 “Universidade Aberta do Brasil: democratização do acesso à educação superior pela rede pública de educação a distância". A sequência marca, portanto, a introdução da Introdução do artigo que constitui, por seu turno, o texto inicial da coletânea "Desafios da educação a distância na formação de professores". Na conjuntura em que é produzida, muito mais ainda por representantes diretos da SEED, a abertura de uma coletânea com um artigo a respeito da UAB não poderia significar senão uma ênfase sobre o Sistema como constituindo a interface mais avançada, atualizada e expressiva entre a EAD e a formação de professores. 
Em segundo lugar, marca a produção do T1 uma espécie de comemoração dos dez anos de criação da SEED. Considerando as limitações de espaço de um artigo, coube à sdr 1 fazer uma ligeira retrospectiva a respeito da atuação daquela Secretaria, providencial o bastante para afirmar sua condição de referência não só nacional, como também internacional, na condução de políticas de EAD. Por isso mesmo, textualmente a SEED recebe maior atenção do que a própria $U A B$, objeto discursivo central ao texto no seu conjunto. Isso não significa, porém, uma contradição, pois a utilização de famílias parafrásticas acaba compensando essa eventual assimetria, possibilitando ao discurso sobre a SEED, no mais das vezes, parecer ou se confundir com aquele referente à $\mathrm{UAB}$, como já assinalamos anteriormente.

Em terceiro lugar, como ainda assim toda introdução deve apresentar as finalidades e imprimir desde então objetividade e coerência ao discurso, mais ainda em se tratando de um discurso de natureza político-institucional, a sdr 1 não perde a oportunidade de anunciar a que se propõe o T1: o objetivo de apresentar o Projeto Universidade Aberta do Brasil, suas bases e criação [...], e sua importância na consolidação [do] Sistema Universidade Aberta do Brasil. É certo que a sequência já apresenta algumas pistas indicando condições que induzem à produção do discurso, tais como: utilização intensiva das tecnologias de informação e comunicação no contexto escolar; marco histórico para a educação a distância no País; e democratização do acesso à educação superior pública, gratuita e de qualidade.

Encontramos essas condições melhor sistematizadas, todavia, no segmento que sucede a sdr 1 e que complementa a Introdução do T1. Embora se reporte explicitamente a alguns fatores recentes (condições de produção 
não discursivas) que confluíram para fazer emergir o projeto $\mathrm{UAB}$, aquele segmento refere-se também, mesmo que implicitamente, a fatores ou condições de produção discursivas que dão ensejo à concepção, estruturação e elaboração do T1. É como se, em resposta a tais condições, os autores decidissem produzir não qualquer um, mas um determinado texto: materialização de ambientes e metodologias educacionais inovadores; o arcabouço legal voltado para a área educacional; ações de fomento e projetos voltados para a educação superior a distância, desenvolvidas pelo Ministério da Educação, esferas governamentais e pelos sistemas de ensino.

Essas condições de produção, de certo modo, são complementadas por outros fatores, vinculados ao desmembramento ou a uma nova dimensão do acontecimento discursivo. Nesse sentido, concebemos o acontecimento 2 que envolve a sdr 1 como sendo, particularmente, de ordem da difusão do discurso. A seqüência faz parte de um artigo que não é divulgado em qualquer tempo, lugar ou por intermédio de qualquer mídia. Como encontramos sugerido quase ao seu final, a produção e publicação do T1 se dá em meio ao período de recebimento de propostas, que vai de 21 de dezembro de 2005 a 13 de abril de 2006, para seleção dos pólos de apoio presencial e dos cursos superiores de EAD, conforme estabelece o Edital n ${ }^{\circ} 1$ da SEED, de 16/12/2005.

Sintomático da forte influência que tende a exercer o edital sobre as três esferas governamentais conclamadas a participar do Sistema UAB, como demonstram os fragmentos grifados a seguir, logo no item 1 que trata "Do Objetivo" daquele regulamento já encontramos enunciados, às vezes, na forma de paráfrases, de suma importância 
ao discurso sobre a UAB que são retomados pelo T1, mais precisamente, pela sdr 1:

O presente Edital tem por objetivo fomentar o "Sistema Universidade Aberta do Brasil - UAB", que será resultante da articulação e integração experimental de instituições de ensino superior, Municípios e Estados, nos termos do artigo 81 da Lei de Diretrizes e Bases da Educação, visando a democratização, expansão e interiorização da oferta de ensino superior público e gratuito no País, bem como ao desenvolvimento de projetos de pesquisa e de metodologias inovadoras de ensino, preferencialmente para a área de formação inicial e continuada de professores da educação básica (BRASIL, 2005a, p.39).

Retomando e (re)atualizando um discurso anterior, inscrito em um acontecimento importante como marco regulatório da política nacional de EAD e que tende a se desdobrar em um conjunto de outros acontecimentos discursivos e não discursivos, o T1 é publicado no livro "Desafios da educação a distância na formação de professores", editado pela SEED. Órgão este que não se trata de qualquer instância de enunciação, mas de uma instituição com caráter estratégico para a educação brasileira e que, ao mesmo tempo, serve de referência internacional na área de educação a distância e de tecnologias educacionais. À primeira vista, tendemos a considerar que essa asserção não passa de uma estratégia discursiva, porém precisamos 
compreender que a importância da rubrica SEED não deixa de ser expressiva.

O fato de a publicação ser editada pela SEED, não apenas por causa da possibilidade de uma tiragem significativa, mas também pela representatividade institucional daquela Secretaria, potencializa sua difusão tanto no Brasil como no exterior. Podendo atingir, dessa forma, instituições governamentais nacionais e estrangeiras, sociedades profissionais e científicas e agências de fomento internacionais que demandam informações e "documentos" importantes às deliberações e avaliações relativamente às políticas públicas no campo da educação. São os textos assinados por "autoridades" que costumam servir de base aos financiamentos, convênios e protocolos de cooperação que geram, por extensão, novos acontecimentos discursivos e em cenários mais amplos.

Além de imprimir credibilidade e de ser mais prático e atraente do que projetos e relatórios, o livro na forma de coletânea acaba pressupondo tanto uma polifonia como uma polissemia que se tornam cruciais a sua difusão, notadamente, em tempos pós-modernos ou de sociedade global e do conhecimento. Sob tal conjuntura, produz-se o efeito de sentido de um discurso polêmico, isto é, "aquele em que a reversibilidade se dá sob certas condições e em que o objeto do discurso está presente, mas sob perspectivas particularizantes dadas pelos participantes que procuram lhe dar uma direção, sendo que a polissemia é controlada." (ORLANDI, 1996a, p.154)

$\mathrm{Na}$ "Apresentação" que escreve para "Desafios da educação a distância na formação de professores", logo depois de acentuar que a publicação representa "uma fértil coletânea de artigos de professores e pesquisadores", o Diretor do Departamento de Políticas em EAD/SEED 
e responsável pela criação e implantação do Projeto UAB faz questão de esclarecer:

Para garantir o caráter plural do conjunto do livro, foram convidados autores de variadas áreas de formação superior, mas todos colaboradores do $\mathrm{MEC}$, e que certamente não reúne "consensos", mas constitui-se substrato de variadas vozes que clamam pela consolidação da modalidade de EAD no Brasil, por meio de diálogo entre diferentes visões (algumas antagônicas, ou talvez complementares), visando a construção de um projeto comum, no qual as diferenças integram o patrimônio comum (CHAVES FILHO, 2006).

Consulta à Plataforma Lattes permite-nos constatar que aquela coletânea deixa de referir que boa parte dos seus "colaboradores" tem assento junto ao MEC, entre outras funções, como membros de comissões de especialistas e consultores ad hoc. Nas referências publicadas em nota de rodapé na página inicial de cada artigo, a publicação não esconde, todavia, que os "autores" ocupam posições de sujeito e lugares determinados em instituições nacionais e estrangeiras, cruciais à política de educação a distância. Há professores e pesquisadores vinculados a instituições de ensino superior católicas e estrangeiras (The Open University do Reino Unido), tomadas como referência em EAD; universidades federais, cuja autonomia administrativo-financeira, inclusive dos antigos e novos projetos em EAD, como a UniRede e a UAB, permanece 
em boa parte subordinada ao MEC; e universidades estaduais que, também, recebem incentivos por parte do governo federal (BIELSCHOWSKY, 2006, p.7).

Por isso mesmo, utilizando-se de paráfrases, o próprio discurso oficial assinala, de antemão, existir diferenças entre os autores de "Desafios da educação a distância na formação de professores" que são mais "complementares" do que "antagônicas" (CHAVES FILHO, 2006). No entremeio dos textos que se seguem ao $\mathrm{T}^{15}$, encontramos a princípio enunciados antagônicos que tendem indicar a heterogeneidade dos discursos: De fato, muitas objeções podem ser feitas; nossas dúvidas; cenário pesado demais; muito ainda precisa ser amadurecido; talvez a necessidade de maiores investimentos na formação. Essas objeções, contudo, parecem propositalmente situadas para, logo em seguida, ser dissipadas não só através de marcas discursivas, na forma de conjunções - No entanto, Mas, Entretanto, como também de assertivas que salvaguardam aquilo mesmo que, até então, era questionado Para tanto, Com isso.

Dessa forma, não se faz necessário ao MEC, diretamente, proclamar que suas ações podem resultar em reflexos profundos, soluções surpreendentes, reflexo mais qualitativo pedagogicamente do que quantitativo ou soluções que viabilizem um verdadeiro processo de inclusão social, pois aqueles "autores" já se encarregam de, espontaneamente, o fazer. Para além das supostas "diferenças", o que percebemos ser articulado pelo discurso oficial são os pontos de convergência entre os "colaboradores do MEC",

15 São os seguintes os textos aí referidos: Fagundes (2006), Franco (2006), Garrido e Silva (2006), Schlunzen, Schlunzen Junior e Terçariol (2006). 
cujas "visões" contribuem para "a construção de um projeto comum, no qual as diferenças integram o patrimônio comum" (CHAVES FILHO, 2006), isto é, elas se apagam ou são positivadas em função (também) de um discurso "comum".

O que colocam em evidência os textos ${ }^{16}$ da coletânea "Desafios da educação a distância na formação de professores", antes de tudo, é a regularidade de um discurso sobre as potencialidades da educação a distância que não se conforma apenas que a EAD está evoluindo e buscando sua própria identidade. Amparando-se em metáforas e metonímias, os "colaboradores do MEC" concebem a EAD como uma marca da esperança, uma maravilhosa aventura, uma (res)significação paradigmática, enfim, uma nova dimensão da educação. Além de se tratar de um meio eficiente e eficaz, a EAD para eles representa o desafio contemporâneo de um país continental socializando o que nós temos de melhor, aglutinando e disseminando o conhecimento.

A ênfase na EAD como sinônimo de melhoria da qualidade da educação é parte indispensável desse discurso. A qualificação da educação, a melhor qualificação dos professores, a pretensão de qualificar, seguindo padrões de qualidade, através de cursos de qualidade, é ponto em comum entre aqueles autores. Mais do que antever uma desafiadora $e$ inovadora iniciativa, perpassa entre eles a convicção de que o cenário é múltiplo, múltiplo de mudança, ou melhor, de uma série de mudanças. Incluindo aquelas que representam

16 Desta feita, são os seguintes os textos referidos: Barbeta (2006), Fagundes (2006), Ferretti et al (2006), Franco (2006), Garrido e Silva (2006), Mundim (2006), Neder (2006), Santos (2006), Schlunzen, Schlunzen Junior e Terçariol (2006). 
alternativas de ultrapassar as dimensões geográficas das diferentes regiões, das diversas regiões, sobretudo, das regiões distantes, regiões onde o transporte se apresenta como um fator limitante.

Uma pergunta e uma resposta os unem definitivamente: O que a EAD tem finalmente de tão inovador? Como se todos os "colaboradores do MEC", espontaneamente, resolvessem escrever uma frase parafraseando a mesma resposta, assim respondem eles: soluções alternativas para democratização do ensino; possibilitar ao profissional de baixa renda ter acesso a Internet $e$ aos ambientes virtuais; acesso; acesso à IES; ampliar o acesso ao ensino superior; democratizar o acesso ao ensino superior e pós-superior; acesso a uma boa formação docente. Estariam eles, todavia, a afirmar a mesma coisa: o que a EAD tem de tão inovador é promover a inclusão social e a democratização do conhecimento. Conforme veremos mais adiante, trata-se de um enunciado caro não apenas à política nacional de educação a distância, como também à política educativa e ao próprio Estado brasileiro contemporâneo.

O discurso dos "colaboradores do MEC", por sinal, não assume declaradamente, mas também não nega que se inscreva em uma formação discursiva dominante. Antes, acima e atravessando a percepção da comunidade acadêmica - ou seja, um sujeito/comunidade discursiva (MAINGUENEAU, 1993), encontramos o posicionamento do governo (e, mais ainda, da UNESCO e BANCO MUNDIAL), um sujeito inscrito na esfera do sujeito universal (PÊCHEUX, 1988) que, ao regular a EAD no ensino superior, tende impor ordem ao discurso (FOUCAULT, 2004) em torno da educação a distância no âmbito da universidade. Uma vez que o governo detectou nas TICs, especialmente na Educação a distância (EAD), uma alternativa 
para resolver os problemas estruturais, parece não restar à comunidade acadêmica senão enxergar a Educação a Distância como uma alternativa para as atuais necessidades de capacitação docente.

Retomando o T1, perceberemos pois que esse ordenamento não se dá de forma automática nem homogênea, mas depende, fundamentalmente, de uma prática discursiva, de cujas bases participam tanto as condições de produção e difusão como as condições de circulação do discurso. O enunciado abertos ao diálogo que ganha ênfase na sdr 1 nos chama atenção para um fato importante: a seqüência possui uma materialidade lingüística, porém não se resume a um texto em si ou a um artigo que faz parte, meramente, de um produto-coletânea. O discurso aí pronunciado constitui, por excelência, um processo que se configura, seguindo nosso raciocínio, através do acontecimento 3 que afeta aquela sequência, desta feita, no campo da circulação dos discursos, atualizando-a por intermédio de outros acontecimentos discursivos, tão ou mais importantes.

Além de sua produção já constituir uma ação que mobiliza uma série de posições de sujeito (patrocinadores, autores, editores etc.), um tempo e um lugar em torno de um discurso, o texto político necessita, muitas vezes, forjar um novo acontecimento discursivo, sob pena de determinadas deliberações acabarem sendo ignoradas. Como nos ensina Courtine (1981), a produção, a difusão e a circulação dos discursos na instância do acontecimento são indissociáveis, evidenciando que a produção de uma seqüência discursiva inscreve-se em uma rede de disseminação dos enunciados que regula a circulação das formulações no interior de uma formação discursiva e estabelece a relação desta com o seu exterior: "el trabajo de una FD como 
memoria discursiva deberá, necesariamente, tomar en cuenta las condiciones de difusión y circulación del archivo."

Por isso mesmo, graças ao seu caráter ao mesmo tempo político e público, os setores de governo buscam estabelecer relações com organizações não governamentais e a sociedade civil que representam, muitas vezes, interlocutores essenciais à repercussão e legitimação do discurso oficial. O lançamento da coletânea "Desafios da educação a distância na formação de professores" acaba sendo feito durante o IV Congresso Brasileiro de Ensino Superior a Distância (IV Esud), oportunidade ímpar para a difusão e circulação de um discurso que atravessa a política de EAD. Até porque, conforme assinala a "Apresentação" da coletânea, a publicação representa uma das "estratégias de colaboração" da SEED com a sociedade, "em momento do cenário nacional bastante propício para o debate sobre a questão da qualidade educacional e da formação de professores." (CHAVES FILHO, 2006)

Realizado em Brasília entre 16 e 19 de maio de 2006, o IV Esud coincide com a fase de análise dos projetos concorrentes ao Edital n ${ }^{\circ} 1$ da SEED, de 16/12/2005, para participação no Sistema UAB. Por um lado, marca o período a expectativa entre os Estados, municípios e universidades em atender aos critérios que uma comissão de especialistas levará em conta para a seleção das propostas de cursos e pólos de apoio presencial. Por outro, perpassa aquele momento a ênfase por parte da SEED/MEC em ampliar suas "estratégias de colaboração" com aquelas instâncias e "toda sociedade brasileira", com vistas especialmente a consolidar e legitimar o Projeto UAB.

O que implica voltar a atenção para o IV Esud que, logo em seus objetivos, mediante paráfrases, reitera a ênfase na formação continuada do professor, na inovação 
tecnológica e metodológica, na integração das instâncias atuantes em EAD e na democratização e qualificação do ensino superior público. $\mathrm{O}$ evento é promovido pelo Centro de Educação a Distância (CEAD) da Universidade de Brasília, em parceria com a SEED e a Universidade Virtual Pública do Brasil (UniRede) que, até a emergência do Sistema UAB, consiste na instância privilegiada de enunciação e execução de políticas na área de EAD (ASSOCIAÇÃO, 2007).

Além da presidente da UniRede e do diretor do CEAD, o IV Esud tem forte presença de representantes do Ministério da Educação. À cerimônia de abertura, no dia 16 de maio de 2006, comparecem o presidente da Capes, o secretário de Educação a Distância e o próprio ministro da Educação. Na ocasião, o ministro faz questão de reconhecer o comprometimento das instituições promotoras do evento (CEAD/UnB, UniRede e SEED) com uma "educação de qualidade". Segundo ele, em consequência da expansão da EAD no país: "O Brasil começa a olhar com outros olhos para a educação a distância." Marca esse avanço, conforme ainda o ministro, o fato de que: “Em 2005, a Seed foi executora de programas e projetos que mudaram os rumos da educação a distância no país [incluindo a UAB]." (BRASIL, 2006d)

Apesar de não economizar em metáforas e metonímias, o ministro não deixa de utilizar paráfrases que retomam enunciados importantes ao T1, como também que atualizam o próprio "Prefácio" assinado pelo mesmo na coletânea "Desafios da educação a distância na formação de professores", lançada também na abertura do IV Esud. No "Prefácio", a ênfase do ministro recai sobre o fato de que, no "contexto da melhoria da qualidade da educação no Brasil", a "Secretaria de Educação a Distância do 
Ministério da Educação vem nos brindar, a toda sociedade brasileira", com uma coletânea que aborda "importantes trabalhos" na área de EAD. Destacando o "Programa Universidade Aberta do Brasil", reitera o ministro que a UAB resulta de "estreita colaboração" entre governo, universidade e sociedade civil "e que será um divisor de águas no tocante à solução definitiva do problema da carência de professores na educação básica, bem como da democratização do acesso dos jovens à educação superior pública, gratuita e de qualidade." (HADDAD, 2006, p.8)

Momentos antes do lançamento da coletânea, em Conferência Magna proferida sobre o tema "Educação no ciberespaço: novas e velhas pedagogias com o uso das tecnologias digitais $\square$, o líder do Grupo de Pesquisa Sociedade do Conhecimento na Faculdade de Educação da Universidade Nacional de Educação a Distância de Madrid (Uned) havia feito "críticas aos entusiastas que acreditam na EaD como solução dos problemas do sistema educacional brasileiro." (ASSOCIAÇÃO, 2006) Em sua palestra "Políticas públicas para expansão do ensino superior a distância", proferida no segundo dia do IV Esud, o secretário da SEED acentua porém que o Brasil acompanha uma tendência em nível global, em que a utilização de mídias na educação já se tornara uma realidade tal que exigia de tais políticas garantirem a sua pronta implementação: “Não se pode mais pensar a educação dissociada das novas tecnologias de informação e comunicação" (BRASIL, 2006h).

Sua afirmação não deixa de aludir à $6^{\mathrm{a}}$ Conferencia Internacional de la Educación y la Formación Basada en las Tecnologias que, de 17 até 19 de maio de 2006, realiza-se em Madrid, com apoio entre outros do governo brasileiro. Organizada pela empresa alemã ICWE (Internacional 
Conferences, Workshops and Exhibitions) (ONLINE, 2006, p.3) e mais conhecida como Online Educa Madrid, "punto de encuentro entre Europa y Latinoamérica", a conferência homenageia o MEC, com a inclusão do secretário da SEED no Comitê de Honra. Segundo ele, o evento representa "o espaço ideal para se conhecer as últimas tendências e inovações da educação virtual e de realizar negócios." (BRASIL, 2006g) Além de reafirmar a importância das "inovações" para a educação, retoma o secretário enunciados que enfatizam as instâncias de interação e articulação como "espaço ideal" para a circulação do discurso (acontecimentos discursivos), assim como para a realização de negócios que podem envolver desde contratos comerciais até convênios institucionais e governamentais (acontecimentos não discursivos).

O representante da SEED, por sinal, volta da Espanha mais convicto em relação aos avanços da EAD no país: "pude perceber o quanto o Brasil é reconhecido como tendo um grande potencial em EAD. Haja vista o fato de terem me chamado para fazer palestra de encerramento. $\mathrm{O}$ que tem de interessante no Brasil é que aqui a EAD nasce sem nenhum preconceito." (BRASIL, 2006a) Evocando o Brasil como referência internacional, ele (re)atualiza o discurso do sucesso alcançado pela SEED na condução da política de EAD e adiciona uma outra idéia que se refere não apenas à ausência de preconceito na aplicação da educação a distância, mas que reforça a sua ausência no campo discursivo e, ao mesmo tempo, inibe a emergência de contradiscursos.

A propósito, poucos dias depois de encerrados o IV ESUD e o Online Educa Madrid, entre 27 e 28 de maio de 2006, o CEAD/UnB promove o primeiro encontro presencial de sua Especialização em Educação a Distância, 
em Brasília, com aula inaugural proferida pelo secretário da SEED. Na ocasião, o diretor do CEAD ressalta: "no momento em que o Governo Federal dá grande impulso a essa modalidade de ensino o curso vem com o objetivo de colaborar na formação de competências para esta modalidade de ensino no Brasil" (BRASIL, 2006e).

Pouco menos de um mês depois, em 19 de junho de 2006, é a vez da própria SEED/MEC, em parceria com a Universidade Federal do Rio Grande Sul (UFRGS) e a Pontifícia Universidade Católica do Rio de Janeiro (PUC-RJ), lançar o Curso de Especialização a Distância em Tecnologias na Educação. Contando com apoio do ambiente colaborativo do e-ProInfo, o curso destina-se a capacitar 1.700 professores da rede pública para atuarem como "multiplicadores" nos Núcleos de Educação Tecnológica (NTEs) das capitais brasileiras. A especialização representa a $35^{\mathrm{a}}$ formação de professores promovida pela SEED (BRASIL, 2006b), cujas ações visam "investir fortemente no uso das Tecnologias de Informação e Comunicação (TIC) na educação pública brasileira, com a perspectiva de elevar o seu padrão de qualidade." (BRASIL, 2006f)

Conforme tivemos oportunidade de demonstrar mais amplamente, mediante pesquisa sobre o discurso da industrialização do ensino em importantes eventos realizados no Brasil, entre meados de 2006 e meados de 2007 (COSTA, 2008, p.178-195), o discurso oficial dissemina-se portanto através de acontecimentos discursivos que criam uma circularidade, ou seja, uma relação contínua e permanente entre a produção de um texto e a sua difusão e circulação enquanto discurso. Isso nos permite compreender por que alguns enunciados têm o privilégio de manter uma regularidade, criando as bases necessárias para a continuidade, 
legitimidade e credibilidade do discurso. Ao realizar o V Esud, conjuntamente ao $6^{\circ}$ Seminário Nacional ABED de Educação a Distância, em Gramado-RS, entre 22 e 25 de abril de 2008, a UniRede parece aproximar, cada vez mais, seus objetivos daqueles que movem a iniciativa privada, consolidando o evento "como o espaço para discussão do estado da arte dos aspectos de gestão, concepção didática e tecnológica relacionada com a educação superior a distância." (ASSOCIAÇÃO; UNIVERSIDADE, 2008)

Como continuidade e descontinuidade são faces de um mesmo processo discursivo, ao privilegiarmos a primeira em nossas análises, estamos considerando que alguns enunciados com importância circunscrita a uma determinada situação de enunciação não guardam a relevância necessária para extrapolar tal circunstância e se (re)apresentar em novos acontecimentos discursivos, cedendo lugar a outros capazes de se repetir mais indefinida e amplamente. Algo que acontece, de modo especial, aos fragmentos de discurso que se reportam à industrialização do ensino na sdr 1 e, extensivamente, no T1.

\section{Fragmentos da industrialização do ensino na UAB}

Como discurso algum é transparente, muitas vezes escapando ao próprio sujeito falante, faltou aos locutores do T1 (melhor dizendo, estava fora de suas competências e propósitos) dizerem aquilo que ficou opaco: o discurso em torno da $\mathrm{UAB}$, na realidade, parte e converge na direção de reiterar o discurso da industrialização do ensino. Essa opacidade, é claro, faz parte do funcionamento discursivo, sendo imanente a este, muito mais ainda, em se tratando de um discurso oficial e de tipo autoritário, 
comprometido com uma dada formação discursiva e ideológica.

Para alcançarmos tal sistema de enunciabilidade, precisamos evidenciar os fragmentos da industrialização do ensino presentes no discurso da política nacional de EAD. Buscaremos elucidar, portanto, a presença e predominância desses fragmentos na sdr 1, ao longo do T1 e, complementarmente, no conjunto do corpus de análise. De antemão, salientamos que essa ocorrência, em geral, não se apresenta de forma evidente, cabendo-nos efetuar a tarefa pretensiosa de deixar transparecer, mediante as relações interdiscursivas, o principal efeito de sentido que visa produzir o discurso oficial - a reprodução e legitimação do discurso da industrialização do ensino.

Em outras palavras, pretendemos desvendar aquilo que o discurso em torno da política de EAD teima em esconder, relega ao esquecimento, ou mesmo, faz questão de passar despercebido que é a recorrência, permanente e sistemática, às seguintes marcas ou propriedades discursivas: racionalização, divisão de trabalho, mecanização, linha de montagem, produção de massa, trabalho preparatório, planejamento, organização, mudança de função e especialização, métodos de controle científicos, formalização, padronização, objetivação, concentração e centralização.

\section{A racionalização do Sistema}

Embora configure fundamento de todo e qualquer processo de industrialização, podendo se traduzir em uma série de outras de suas condições estruturais, a racionalização é uma das primeiras características da industrialização do ensino que encontramos evocada na sdr 1 . De 
início, convém ressaltarmos que o enunciado atuado transversalmente tende referir muito mais do que apenas ações e gestões que a SEED tem efetuado junto às demais secretarias e órgãos do MEC. O enunciado faz alusão, sobremaneira, a uma performance que tem como base os princípios racionais de uma atuação eficiente e eficaz. Não fosse assim, do mesmo modo que certamente empregou a política do silêncio (ORLANDI, 1997) a outros objetos, o sujeito do discurso teria relegado aquela atuação ao esquecimento ${ }^{17}$.

Empregarmos a racionalização é importante, ainda, para aproximarmos dois outros fragmentos que, em princípio, dizem respeito a referentes distintos: intensa articulação e utilização intensiva. Mesmo considerando que o primeiro esteja associado, de forma direta e imediata, a instituições (SEED/MEC e sistemas de ensino) e o segundo ao uso das TICs no contexto escolar, chama-nos a atenção o fato de que os adjetivos usados para dimensionar os processos de articulação e de utilização são, praticamente, sinônimos. Melhor ainda, intensa e intensiva remontam, a um só tempo, atividades realizadas de forma austera, em curto prazo e numa dinâmica a mais intensificada possível, representando pois adotar critérios de máxima racionalização daqueles processos.

17 Em seu "Prefácio" à coletânea que inclui o T1, o ministro da Educação já faz a seguinte observação: "Quero enaltecer o importante papel 'transversal' da Secretaria de Educação a Distância, que tem sido a ponte simbólica entre os diversos órgãos deste ministério, na consolidação da visão sistêmica da educação, proporcionando os benefícios do aporte de tecnologias de informação e comunicação à educação, desde a produção do conhecimento até a extensão dos seus benefícios à população." (HADDAD, 2006, p.9) 
Semelhantemente, não observamos à primeira vista qualquer outra relação que não seja objetiva entre os constituintes do enunciado inovações tecnológicas e metodológicas para a melhoria da qualidade da educação no país. Além do mais, um pouco mais adiante, o enunciado é retomado através do verbo inovar que produz aquele mesmo efeito de sentido, só que no âmbito específico da educação superior. Examinados do ponto de vista discursivo, esses fragmentos fazem alusão a elementos cruciais aos processos de racionalização que são as relações de causa e efeito, custo e benefício. Notadamente, quando consideramos que as inovações científico-tecnológicas visam, de forma pragmática, otimizar os resultados da produção de bens e serviços, a exemplo da qualidade dos sistemas de ensino superior.

Nessa mesma linha, encontramos o enunciado sucesso alcançado pela SEED. Ao invés apenas de registrar um acontecimento exitoso na trajetória daquela instituição, o enunciado reitera a importância da relação custo-benefício na atuação da administração pública que, dessa forma, deve seguir a racionalidade da iniciativa privada, para a qual todo esforço ou investimento precisa lograr um excelente resultado. $\mathrm{O}$ fragmento destacado a seguir, por sinal, sintetiza melhor ainda como essa racionalização dos meios e fins pontua a sdr 1 :

Hoje, considerando-se o espectro de projetos e programas por ela [SEED] desenvolvidos, desde a regulamentação para educação a distância, passando pelos programas de formação, o desenvolvimento de conteúdos multimídia, e com forte incentivo à pesquisa para o setor, podemos afirmar seu caráter estratégico para a educação brasileira. 
A alusão aos princípios da racionalização, todavia, não se resume à sdr 1, afetando o T1 como um todo. Um conjunto de enunciados dispersos e difusos marca essa continuidade, desde o domínio produtivo do conhecimento que confere ênfase a um princípio essencial à racionalidade - a produtividade - até a adoção de medidas com base nos princípios da eficiência e da eficácia: forte potencial de solução para esse quadro; ações e projetos que buscam potencializar as políticas públicas educacionais; essas ações poderão multiplicar-se em número, além de melhorar em qualidade.

Os princípios da inovação e do custo-benefício, também, são retomados. O primeiro através dos enunciados constantes avanços tecnológicos e materialização de ambientes e metodologias educacionais inovadores e, o segundo, mediante os seguintes fragmentos que mantêm a preocupação em relacionar ações e resultados: extensão de seus benefícios à população e $O$ nível de formação dos docentes guarda forte relação com o desempenho dos estudantes. Mais sintomáticos dessa relação, ainda, demonstram ser os enunciados custo estimado por aluno; estimativa de custo para o material impresso e $O$ custo dos alunos com vínculos com as empresas estatais serão cobertos pelas mesmas. O que indica ser fundamental às empresas envolvidas estabelecer minuciosamente a implicação do custo-benefício da formação de cada aluno na $\mathrm{UAB}$, sobretudo quando consideramos que elas são obrigadas a prestar contas de seus investimentos.

A ênfase sobre a racionalização não se esgota aí, pelo contrário. Encontramos alguns enunciados no T1 que se mostram ainda mais incisivos, a ponto de recorrerem à seguinte analogia: Pretende-se que o sistema de biblioteca seja idealizado como uma Unidade de Informação. Como veremos adiante ao analisarmos os fragmentos relativos à mecanização, concentração e centralização, a descrição 
daquela unidade não difere em nada, praticamente, de qualquer outro tipo de unidade de produção, em moldes industriais ou racionais. Tanto é que, na sua essência, o projeto UAB caracteriza-se pela reafirmação do caráter estratégico desse nível educacional, do desenvolvimento científico e da inovação tecnológica para o crescimento sustentado do país, além de estabelecer metas e ações para a promoção da educação inclusiva e cidadã. Invoca-se pela reafirmação, portanto, o primado da educação superior, do desenvolvimento científico e da inovação tecnológica (algo caro ao projeto de racionalidade da sociedade industrial) como condição para o crescimento sustentado do país e a educação inclusiva e cidadã, fenômenos por sua vez que seriam típicos a uma sociedade pós-industrial.

O conjunto dos princípios da racionalização vai se apresentar junto ao T1 de forma mais articulada, entretanto, na seguinte série consecutiva de fragmentos: ações que vêm ocorrendo de maneira individualizada e não sistemática, com sobreposição de esforços e recursos; O estabelecimento de parcerias nacionais seria extremamente proficuo, pois possibilitaria a troca de experiências, o compartilhamento de instalações tecnológicas, a elaboração conjunta de ferramentas de comunicação e de material didático, economizando tempo e investimento; com esse princípio de trabalho conjunto, as universidades e as Empresas Estatais estarão favorecendo o desenvolvimento científico, tecnológico e social do país.

Antes de tudo, o sujeito do discurso chama atenção de que estariam sendo desenvolvidas iniciativas de forma irracional que, no fundo, contradizem a lógica do Estado contemporâneo: ações que vêm ocorrendo de maneira individualizada e não sistemática, com sobreposição de esforços e recursos. Razão que torna imprescindível o estabelecimento de parcerias nacionais (amplas e sistemáticas) que seria - o 
verbo no futuro do pretérito não indica hipótese, incerteza ou irrealidade, mas uma estratégia discursiva utilizada para não impor uma idéia de maneira imediata - extremamente profícuo (o que retoma produtividade, eficiência, eficácia) para imprimir racionalidade àquele processo assistemático.

Mesmo porque a troca de experiências, o compartilhamento de instalações tecnológicas, a elaboração conjunta de ferramentas de comunicação e de material didático decerto possibilitaria (forma verbal empregada para produzir o mesmo efeito de sentido do caso anterior) dotar aquelas ações de princípios racionais por excelência, economizando tempo e investimento. Não restando dúvida, portanto, de que o princípio de trabalho conjunto, baseado na justaposição (e não na sobreposição) de esforços e recursos e na economia de insumos conduz ao desenvolvimento científico, tecnológico e social do país, aos marcos, pois, de um país industrializado.

Divisão de trabalho e especialização burocrático-profissional

Paralelamente aos vestígios da racionalização, encontramos na sdr 1 fragmentos de três outras características estruturais da industrialização do ensino - divisão de trabalho, linha de montagem e mudança de função/ especialização. Nossa análise das três condições conjuntamente parte do pressuposto de que o processo de produção em EAD, assim como acontece à produção industrial, mobiliza instâncias e profissionais de diversas origens e competências.

A simples referência a esses agentes ao longo da seqüência oferece-nos uma boa idéia de como o sistema de produção que envolve a UAB é amplo e complexo: Secretaria de Educação a Distância (SEED); Ministério da 
Educação; demais secretarias e órgãos do MEC; sistemas de ensino; contexto escolar; programas TV Escola e Proinfo; espectro de projetos e programas; programas de formação; parceiros de projetos; instituições de educação superior; Secretarias Estaduais de Educação; Projeto Universidade Aberta do Brasil; novas redes de colaboração; novos e diferenciados partícipes; Fórum das Estatais pela Educação; rede nacional de educação a distância; Sistema Universidade Aberta do Brasil; Estados e Municípios; três esferas governamentais.

Essa relação generalizada, porém, não nos permite precisar os vínculos e as competências institucionais e profissionais de cada membro junto à UAB. Algumas pistas nessa direção, de todo modo, são fornecidas pela sdr 1, destacando-se inicialmente aquelas que reiteram o nome de determinadas instituições: Secretaria de Educação a Distância (SEED), demais secretarias e órgãos do MEC, instituições de educação superior, Secretarias Estaduais de Educação - evocadas, novamente, através dos Estados e Municípios - e Sistema Universidade Aberta do Brasil, reiterado como Projeto Universidade Aberta do Brasil e rede nacional de educação a distância. $\mathrm{O}$ fragmento que reproduzimos a seguir representa um bom indício da ênfase sobre essas instâncias: "Grande parte do sucesso alcançado pela SEED nesses dez anos de vida, se deve à estratégia de trabalho colaborativo com os parceiros de projetos, em destaque as instituições de educação superior, as Secretarias Estaduais de Educação e as demais Secretarias do MEC".

Além de sua maior ocorrência, acontece que o discurso em torno dessas instituições é pontuado por uma série de alusões que nos permitem compreender a participação de cada uma delas no conjunto do processo. O papel da $S E E D$ é logo definido e destacado, graças não somente ao seu vínculo institucional mais amplo - Ministério da 
Educação, o que remonta à instância do Governo Federal responsável pela política educativa brasileira, como também por força de sua competência específica - Secretaria de Educação a Distância - e distinta das demais secretarias e órgãos do MEC.

Junto a estas, todavia, a SEED tem atuado transversalmente, evocando uma capacidade extremada de interlocução com uma série de órgãos ligados diretamente ao MEC e a cinco outras secretarias que compõem a estrutura do Ministério (SEB, Sesu, Setec, SEESP e Secad). O que estende a influência da SEED desde o ensino básico e superior até a educação profissional, tecnológica, especial e continuada, incluindo a alfabetização e diversidade. A Secretaria tem atuado, além disso, em intensa articulação com os sistemas de ensino, o que produz um novo efeito de sentido, ampliando seu raio de influência até os limites da rede pública federal, estadual e municipal de educação.

Após uma década de experiências, sua estratégia de trabalho colaborativo com os parceiros de projetos é retomada de forma exemplar, a ponto de ter sido responsável por Grande parte do sucesso alcançado pela SEED, tanto no país quanto lá fora. No Brasil, destacando-se por seu caráter estratégico para a educação brasileira; no exterior, na condição de referência internacional na área de educação a distância e de tecnologias educacionais. Cabendo-lhe, pois, como requer qualquer organização que atua no mercado ou em outro ambiente social, também fazer o marketing de suas ações que se estende ao MEC e ao Governo Federal que representa. No conjunto, desenvolve a SEED um espectro de projetos e programas, desde a regulamentação para educação a distância, passando pelos programas de formação, o desenvolvimento de conteúdos multimídia, e com forte incentivo à pesquisa para o setor, que lhe permitem assumir a função privilegiada de conduzir a política nacional de EAD. 
Depois da SEED, observamos que é o próprio Sistema Universidade Aberta do Brasil que tem seu lugar determinado em meio à sdr 1 . Mesmo ainda mencionado como Projeto, a UAB assume o papel de dispositivo por meio do qual será possível inovar, o que remete a uma capacidade inata de promover a utilização intensiva e racional das inovações tecnológicas e metodológicas; assim como propor modelo alternativo para a oferta e gestão de educação superior, tendo como referência a educação a distância. Cabe à UAB como Projeto, ainda, favorecer o estabelecimento de novas redes de colaboração, com novos e diferenciados partícipes, renovando e ampliando de forma substancial o leque dos antigos parceiros de projetos da SEED.

Além de sua importância na consolidação da rede nacional de educação a distância, numa alusão às instituições de educação superior públicas, compete à $\mathrm{UAB}$ enquanto Sistema atuar cristalizando a união de esforços das três esferas governamentais, consolidando e maximizando as suas possibilidades de articulação. De sorte que, sobretudo quando consideramos que tem em vista a democratização do acesso à educação superior pública, gratuita e de qualidade, percebemos que a UAB exerce uma função central, na mesma linha da referência internacional e do caráter estratégico associados à SEED. Ao incorporar o papel de marco histórico para a educação a distância no País, a UAB passa a representar a instância, por excelência, capaz de atualizar a educação superior pública brasileira aos avanços representados pelo modelo emergente da universidade aberta, virtual e global.

As instituições de educação superior, as Secretarias Estaduais de Educação e as demais Secretarias do MEC, apesar de também destacadas na sdr 1, são aludidas como ocupando uma espécie de lugar secundário no processo de 
produção envolvendo o Sistema UAB: Ele será formado pelas instituições federais de educação superior, em estreita relação com os Estados e Municípios, cristalizando a união de esforços das três esferas governamentais. Somente analisando o T1 no seu conjunto é que vamos perceber como os lugares dessas instâncias encontram-se bem definidos, assim como as posições ocupadas pelas demais instituições e agentes evocados pelo sujeito do discurso que se vê afetado, sensivelmente, pela formação discursiva responsável por suas reiteradas menções à divisão de trabalho, linha de montagem e mudança de função/especialização.

O próprio T1 em si já encerra uma organização formal atravessada pelo processo de produção industrial. Começa pelo fato de que é produzido por um grupo de locutores, cada qual representando uma instância de competência da SEED essencial ao discurso sobre a UAB: a Coordenação-Geral de Articulação Institucional, a quem caberia, a princípio, a ênfase sobre as parcerias; o Departamento de Políticas em EAD, ao qual competiria referenciar os projetos e programas; a própria Secretaria, à qual estaria atribuída a "palavra final" em torno da $\mathrm{UAB}$; e, por último, representado inclusive através desses agentes, o MEC, responsável pelas menções histórico-estruturais à EAD, educação e política educativa em geral. Um fragmento significativo dessa divisão de trabalho é o seguinte enunciado, constante da legenda que subscreve cada uma das três tabelas sobre funções docentes, apresentadas no entremeio do texto: Tabela elaborada por $M E C /$ SEED/DPEAD/CGAI.

Essa instância de produção, até por força da complexidade e riqueza intrínsecas à temática em questão (como já salientado na sdr 1), acaba mobilizando outras instâncias produtoras de discurso, formando com elas praticamente 
uma cadeia produtiva, sob a égide da formação discursiva aí predominante. Na contextualização que elabora, objetivando apresentar Alguns dados sobre oferta e atendimento na educação superior brasileira e Alguns dados sobre docentes e formação docente no Brasil, o sujeito do discurso logo se apóia em uma série de outras instâncias estratégicas ao processo de enunciação: Constituição Federal, Lei $n^{0}$ 9.394/96 - Lei de Diretrizes e Bases da Educação Brasileira e Plano Nacional de Educação, criado pela Lei 10.271/01, referenciando um marco regulatório, a princípio, originário do Congresso Nacional; IBGE/PNAD/200418, INEP/Censo Escolar 2005, www.edudatabrasil.inep.gov.br (em alusão ao Sistema de Estatísticas Educacionais-Edudatabrasil), e INEP/SAEB (em alusão ao Sistema Nacional de Avaliação da Educação Básica), evocando dessa forma bases de dados vinculadas ao próprio Governo Federal.

Avançando o texto, ao elaborar tópico sobre O Projeto UAB no Fórum das Estatais pela Educação, o sujeito do discurso mobiliza duas outras instâncias importantes - o Fórum e, novamente, o Projeto Universidade Aberta do Brasil. Como sugerem as Referências Bibliográficas ao final do T1, as alusões ao primeiro apóiam-se no Diálogo para a cidadania e inclusão - Texto-Base, documento originário que lança as bases daquela instância. As menções ao segundo têm como base, por sua vez, o próprio Projeto $U A B$, cuja produção capitaneada pela SEED representa a convergência de esforços das instituições participantes do Fórum, em especial, o Governo Federal, empresas estatais e a Associação Nacional

18 Levando em conta que a mesma Pesquisa Nacional por Amostra de Domicílios é reiterada como Brasil 2002 - Pnad/ IBGE e Brasil 2002 - PNAD/IBGE, consideramos esta última como prevalecente. 
dos Dirigentes das Instituições Federais de Ensino Superior - ANDIFES.

Os tópicos restantes do T1 apóiam-se em editais públicos e, mais uma vez, na SEED. No que se refere ao tópico O Projeto-Piloto com o Banco do Brasil, sua produção nos é sugerida a partir do seguinte enunciado que antecede toda uma descrição sobre aquele projeto: Os editais para os processos seletivos foram divulgados em rede nacional em 17 de abril de 2005. Caso semelhante acontece ao tópico O Edital de Convocação, cuja produção teria como base edital público, lançado em 20 de dezembro de 2005.

Além de ser da competência da SEED elaborar esses editais por força de prerrogativa institucional que, por sua vez, evocam marcos regulatórios mais abrangentes, o texto é finalizado através do tópico Projetos encaminhados para avaliação que tem origem naquela Secretaria, como demonstra o seguinte fragmento: Até a data limite de 13 de abril de 2006, a SEED havia contabilizado. Completando-se, dessa forma, o próprio ciclo de produção do discurso em torno da UAB que privilegia a SEED, porém reúne outras instâncias de enunciação invocadas, direta e indiretamente, pelo sujeito do discurso.

Cabe ao T1, por isso mesmo, ampliar o quadro das instâncias vinculadas à $\mathrm{UAB}$, além daquelas já referidas e retomadas em forma de paráfrase, através de fragmentos, tais como: ambientes e metodologias educacionais inovadores; IBGE; INEP; setor público; políticas públicas educacionais; sala de aula; nível/modalidade de ensino; Creche; Pré-Escola; educação básica; Ensino Fundamental; Ensino Médio; modalidade Educação de Jovens e Adultos (EJA); Educação Especial; Educação Profissional e Tecnológica; Região Norte; Região Nordeste; Centro-Oeste; Região Sudeste; Região Sul; toda a sociedade brasileira. Em meio à dispersão e difusão dessas 
instâncias é que vamos encontrar, em particular, as demais Secretarias do MEC, as Secretarias Estaduais de Educação e as instituições de educação superior assumindo lugares determinados no Sistema $U A B$.

Muito embora não faça mais nenhuma referência direta às demais Secretarias do $M E C$, o sujeito do discurso retoma-as no T1, principalmente, por ocasião dos tópicos Alguns dados sobre oferta e atendimento na educação superior brasileira e Alguns dados sobre docentes e formação docente no Brasil. A ênfase aí dispensada aos baixos índices de acesso à educação superior e de formação dos professores acaba fazendo alusão aos diversos níveis e modalidades do sistema educacional, cuja competência, em primeira instância, cabe às secretarias vinculadas ao MEC, responsáveis desde a Creche, Pré-Escola, Ensino Fundamental, Médio e superior até a Educação de Jovens e Adultos (EJA), Especial, Profissional e Tecnológica.

Conforme nos evidencia o fragmento destacado a seguir, como a problemática afeta, sensivelmente, a alçada da SEED (Educação a Distância), o desenho proposto para o Sistema Universidade Aberta do Brasil, apresenta forte potencial de solução para esse quadro, pois reunirá, em um grande movimento nacional, as Instituições de Educação superior e as demais esferas governamentais [aí, também, aludidas as demais Secretarias do MEC], em torno da questão: democratização da educação superior e formação inicial e continuada de professores.

O papel das Secretarias Estaduais de Educação é definido, por sua vez, a partir das menções dirigidas aos estados $e$ municípios. Ao longo do T1, encontramos uma série de fragmentos que nos permitem ir recompondo suas responsabilidades: sistemas de ensino; educação básica; cenário nacional de assimetrias educacionais; regiões distantes; mais distantes rincões do nosso país; centros regionais de desenvolvimento; 
pólos regionais; esferas estaduais e municipais; cada unidade da federação participante; dirigentes de Municípios, de Estados $e$ do Distrito Federal. O lugar reservado a essas instâncias junto ao Sistema $U A B$, enfim, é salientado através do seguinte enunciado, constante do último parágrafo do texto: quatrocentos e nove municípios proponentes, totalizando quatrocentos e quatorze projetos de pólos de apoio presencial, em todas as vinte e sete unidades da federação, cabendo-lhes, em síntese, além de propor, colocar em pleno funcionamento os pólos aprovados.

O enunciado é sucedido por um fragmento que nos oferece uma boa idéia, desta feita, das atribuições concernentes às IFES: Em relação ao projetos de cursos superiores na modalidade a distância, foram contabilizadas trinta e sete universidades federais e onze centros federais de educação tecnológica (Cefets) proponentes, com forte concentração da oferta nas licenciaturas, cabendo-lhes, pois, além de propor, colocar em pleno funcionamento os cursos selecionados. Antes disso, observamos desde a Introdução do T1 uma variedade de fragmentos que, mesmo às vezes dispersos ou difusos, reforçam as alusões ao papel destinado pela UAB às instituições públicas de educação superior, tais como: capilarização e interiorização da oferta; trabalho de gestão da educação superior na dinâmica de rede; formação superior inicial e continuada; habilitação para exercer a docência; e universidade pública e gratuita.

Além das Secretarias do MEC, Secretarias Estaduais e IES, o Fórum das Estatais pela Educação constitui a outra instância importante que tem seu papel evocado no T1. Como acontece à sdr 1, as menções feitas pelo sujeito do discurso ao Fórum não são tão extensas, mas se apresentam bastante enfáticas, como por exemplo: espaço de diálogo e interlocução entre Ministério da Educação, Governo Federal, 
estatais brasileiras e toda a sociedade brasileira; instâncias propositivas de ações e projetos que buscam potencializar as politicas públicas educacionais promovidas pelo Governo Federal; fértil parceria entre Empresas Estatais e universidades públicas. No fundo, conforme demonstram os fragmentos que reunimos a seguir considerando sua complementaridade discursiva, o conjunto das instituições participantes do Fórum das Estatais da Educação [se o "da" não indicar um erro de digitação, teríamos aí um efeito de sentido restringindo o Fórum às estatais da área de educação] propõe a criação do Sistema $U A B$, representando a convergência de esforços das instituições participantes do Fórum e, em particular, elegendo as empresas estatais como parceiras potenciais no compartilhamento colaborativo de experiências em EAD.

A racionalidade da cadeia produtiva que envolve a UAB manifesta-se de modo mais contundente, ainda, quando examinamos a série de fragmentos marcada por um processo de divisão de trabalho, linha de montagem e, principalmente, mudança de função e especialização dos agentes envolvidos, destacando-se os seguintes: 0 sistema de tutoria consistirá de duas modalidades de tutoria: tutoria local e a distância; os estudantes contarão com o acompanhamento de um coordenador de área que estará no pólo em regime de 15 horas semanais; tutoria a distância - será realizada por meio de fax, telefone e Internet; Cada aluno será acompanhado a distância, em cada disciplina, por docentes de reconhecida competência; Auxiliando tais professores haverá um corpo de tutores em nível de pós-graduação; Será criado um esquema de tarefas em que os estudantes contarão com um sistema de consulta capaz de esclarecer dúvidas por telefone, fax ou Internet.

O telefone, fax ou Internet não é reiterada aí de forma aleatória, mas como agente também participante do processo, aliás, de igual ou até maior importância. O 
enunciado tutoria a distância - será realizada por meio de fax, telefone e Internet alude, na verdade, à outra característica fundamental à industrialização do ensino - a mecanização. Sobretudo num contexto em que, cada vez mais, acentua-se a automação dos processos de ensino e aprendizagem, cujo maior expoente é a universidade virtual e global, a mecanização representa não apenas uma condição sine qua non, como também ocupa o lugar de protagonista na expansão e consolidação da educação a distância.

\section{Mecanização e virtualidade da educação}

As alusões à mecanização atravessam, praticamente, todo o T1, ganhando relevo desde a sdr 1 . Nos três segmentos que compõem a sequência, seja de forma referencial seja através de paráfrases, encontramos marcas textuais ou fragmentos que remetem aos processos mecânicos de ensino-aprendizagem. Mais do que a ênfase à SEED, que ali ocupa um lugar determinado historicamente mas que poderia ser assumido por qualquer outro representante designado pelo aparelho de Estado, o que marca o discurso de abertura da sdr 1 é a utilização intensiva das tecnologias de informação e comunicação no contexto escolar, buscando inovações tecnológicas e metodológicas para a melhoria da qualidade da educação no país.

Chama-nos a atenção, de imediato, o fato de que o enunciado utilização intensiva das tecnologias de informação e comunicação é típico à caracterização da EAD como forma avançada de industrialização do ensino, demarcando uma de suas principais distinções em relação à educação presencial. Se nesta, quando utilizadas, as TICs são empregadas gradativamente, na EAD torna-se crucial que sejam aplicadas constantemente, sob pena de rompimento do 
processo de ensino e aprendizagem a distância. Razão pela qual não observamos qualquer reticência por parte do sujeito do discurso nesse sentido, pelo contrário, até porque mobiliza ele uma formação discursiva responsável pela legitimação da ideologia da utilização intensiva das TICs no contexto escolar, seja virtual seja semi-presencial.

Logo em seguida, encontramos a alusão inovações tecnológicas e metodológicas associada diretamente à utilização intensiva das TICs, por relação de identificação, justaposição, ou mesmo, sobredeterminação. O que, a princípio, supõe que as tecnologias incluem-se entre as inúmeras manifestações do processo de inovação das metodologias e das técnicas em geral. No entanto, as reiterações ao longo da seqüência privilegiam as TICs como representando plena e legitimamente esse processo, aludido como de fundamental importância à melhoria da qualidade da educação no país.

Ainda no primeiro segmento que compõe a sdr 1, observamos três enunciados que retomam as TICs como referentes imediatos: tecnologias educacionais, conteúdos multimídia, TV Escola e Proinfo. Embora faça alusão a dois programas da SEED, referidos com nomes próprios, este último fragmento não deixa de produzir como efeito de sentido a idéia da TV e do computador como recursos ou inovações tecnológicas. No segundo e terceiro segmentos, apesar das referências reduzirem-se e se tornarem mais amplas, encontramos fragmentos que continuam invocando a presença das TICs. Além de educação a distância já se associar, quase que automaticamente, às tecnologias educacionais, os enunciados redes de colaboração e rede nacional de educação a distância logo fazem lembrar a rede mundial de computadores. O que permite incorporar ao discurso uma memória discursiva que atribui à internet 
a capacidade ilimitada e sem precedentes de formar uma "aldeia global", integrando e multiplicando os contatos e as parcerias, estratégicas ao Sistema UAB.

A propósito, o fragmento Sistema remonta aos sistemas de comunicação que, antes mesmo da idéia de rede, representam o que há de mais avançado em termos de meios de informação e comunicação. Estreitamente vinculadas a esses sistemas, vamos encontrar as tecnologias associadas às primeiras gerações da $\mathrm{EAD}$, em destaque a teleducação, potencializada nas últimas décadas pelos avanços da informática que resultam na videoconferência e na teleconferência. A referência Universidade Aberta, por sinal, faz alusão às tradicionais universidades a distância do mundo, em especial The Open University do Reino Unido, nascida nos anos 1960 originalmente como Universidade do Ar.

Como determinados discursos sempre se repetem, embora em contextos às vezes diferentes, o "argumento do uso da tecnologia para o avanço do conhecimento e para a expansão da educação no País" assumido pela The Open University (SANTOS, 2006, p.212) é retomado pelo Sistema Universidade Aberta do Brasil. Conforme demonstra o seguinte fragmento do T1 que imediatamente sucede a sdr 1, a perspectiva adotada deverá ir muito além da dimensão metodológica ou de mera aplicação da tecnologia no ensino, mas também de um sistema de educação a distância capaz de enfrentar os desafios dos baixos níveis de atendimento na educação superior.

Além disso, a UAB segue a pedagogia de ensino empregada pela The Open University ("Supported Open Learning" ou Aprendizagem Aberta Apoiada) que pressupõe a "combinação de métodos e mídias para o contato com o aluno, conhecida na área de educação a distância 
como 'blended learning' [...] Há também o contato presencial com o tutor, que não é obrigatório, e que acontece em média uma vez por mês." (SANTOS, 2006, p.216) Se na $\mathrm{UAB}$ os encontros presenciais aparentam ser estimulados, a aprendizagem a distância permanece entretanto como foco central. Nesse sentido, chama-nos a atenção o seguinte fragmento do T1: há que se fomentar o campo de pesquisas em tecnologias de informação e comunicação, outra importante missão para o Sistema Universidade Aberta.

Conseguimos apreender essa ênfase, melhor ainda, à medida que analisamos como se manifestam os vestígios da mecanização ao longo do texto, representados de modo exemplar por intermédio do seguinte fragmento: utilização de variadas tecnologias: impressos, vídeos, multimídia, Internet, fóruns virtuais e videoconferências. Como forma, inclusive, de avalizar essa recorrência, o sujeito do discurso finaliza o T1 adicionando um conjunto de onze Referências Bibliográficas, das quais apenas uma não faz menção direta às tecnologias: Diálogo para a cidadania e inclusão - Texto-Base. Isto porque se trata, a princípio, de um documento devotado a questões mais amplas envolvendo a educação. O que não impede, todavia, de vislumbrarmos no seu entremeio uma alusão importante nesse sentido, isto é, Diálogo que, no campo da EAD, logo remete a um processo de mediação.

Razão pela qual, seguindo inclusive as recomendações de um artigo acadêmico-científico, as Referências à mediação apresentam-se através de fragmentos bastante expressivos, desde educação a distância, Comunicação e educação até interface, Universidade Aberta e Sala de aula interativa. Alguns enunciados, além disso, são extremamente ricos de sentidos: Máquina e Imaginário: O desafio das Poéticas Tecnológicas; Novas tecnologias e mediação pedagógica; e, por 
último, Hipertexto, fechamento e o uso de não-linearidade discursiva. Apesar de produzir um efeito de sentido associado ao dialogismo, a mediação aí referida não poderia deixar de invocar os tradicionais e contemporâneos " mass media" (de onde deriva "mediação") que representam, em última instância, a incorporação à educação dos processos de mecanização e automação.

Ainda que a maioria das Referências não seja diretamente evocada ao longo do T1, observamos que a mecanização é a característica da industrialização do ensino que mais alusões recebe por parte do texto, de modo geral, dirigidas às TICs: recursos tecnológicos de informação e comunicação, infra-estrutura computacional e de telecomunicações, laboratórios de informática, mídias, entre outras. Ao lado destas, encontramos fragmentos que remontam às tecnologias tradicionais, tais como, equipamentos, diferentes suportes informacionais (conteúdos), conteúdos pedagógicos, ferramentas de comunicação e de material didático, material didático em mídia eletrônica e material impresso.

Mesmo assim, percebemos que a ênfase recai sobre as TICs, sobretudo quando relacionadas, caracterizadas ou comparadas aos suportes menos sofisticados: infra-estrutura física e logística de funcionamento (laboratórios didáticos e de informática, bibliotecas, recursos tecnológicos e outros); avanços dos recursos tecnológicos de informação e comunicação, especialmente das tecnologias digitais, potencializando práticas de EAD - as quais tradicionalmente estavam apoiadas em material impresso distribuído por correspondência. Essa evocação da relação tradicional-moderno, bastante representada por intermédio da evolução da tecnologia, é acentuada através de outros fragmentos que reforçam os avanços tecnológicos, a inovação tecnológica ou os ambientes e metodologias educacionais inovadores. 
Dessa forma, o sujeito do discurso nos seduz a professar com ele a fé de que a inovação pedagógica deriva, precipuamente, da modernidade tecnológica. $\mathrm{O}$ que implica a racionalização crescente das relações de ensino e de aprendizagem, mediante a qual a mecanização passa a constituir condição "sine qua non" à EAD, como bem demonstram os fragmentos que salientamos a seguir: Os pólos terão infra-estrutura computacional e de telecomunicações equivalentes às existentes nas universidades para as atividades de coordenação do pólo e tutoria; Além dessa infra-estrutura, os pólos contarão com laboratórios de informática para atendimento aos alunos e também com equipamentos para utilização das mídias necessárias ao curso.

A reiteração da infra-estrutura, através de referências, co-referências ou paráfrases, não é aleatória. Até porque, um pouco mais adiante do texto, chama-nos a atenção o seguinte enunciado: Serão considerados para efeito de seleção do pólo, especialmente, a análise da infra-estrutura física do pólo proposto e recursos humanos disponíveis. Não parece forçoso lembrarmos que a análise destes últimos deve levar em conta suas competências e habilidades no manuseio das TICs, não sendo qualquer profissional, portanto, que é convocado a participar do Sistema UAB.

A racionalidade deste no emprego da tecnologia chega ao ponto de induzir o próprio sujeito do discurso (e este, por extensão, o destinatário) a idealizar o sistema de biblioteca, como sugere o próprio nome, tal qual uma unidade de produção informacional, conforme ilustram os seguintes fragmentos: Como Unidade de Informação entende-se um sistema de recuperação de informação (SRI) informatizado que visa à gestão/organização; bem como ao planejamento, aquisição, processamento, armazenamento e disseminação/transferência da informação contida em documentos de diversas naturezas. 
Em meio aos fragmentos acima reproduzidos, encontramos mencionadas duas outras características da industrialização do ensino que não aparecem aí por acaso - gestão/organização e planejamento. Associadas a outras características da EAD - trabalho preparatório, métodos de controle científicos, formalização, padronização, objetivação, concentração e centralização, formam elas um conjunto de condições estruturais que, também, afetam o Sistema $U A B$, ampliando e potencializando os seus níveis de racionalidade. Por isso mesmo, decidimos analisá-las em conjunto, considerando não apenas que configuram reflexos importantes dos processos de racionalização, divisão de trabalho e mecanização, bem como estabelecem entre si laços fortes de interdependência, demarcados através de traços que atravessam o T1 no seu conjunto.

Do trabalho preparatório à centralização administrativa

O próprio T1 em si, além do que já assinalamos anteriormente, tem como propósito anunciar o Sistema $U A B$, exercendo uma função inerente ao trabalho preparatório, ao planejamento e/ou à organização em EAD. Influi sobre sua produção o fato de que a implementação, consolidação e legitimação da UAB pressupõe toda uma fase de preparação, envolvendo inclusive estratégias discursivas. Na sdr 1, já observamos traços expressivos nesse sentido, sintetizados por intermédio do seguinte fragmento: elaboramos este artigo com o objetivo de apresentar o Projeto Universidade Aberta do Brasil, suas bases e criação no âmbito do Fórum das Estatais pela Educação, e sua importância na consolidação da rede nacional de educação a distância, a qual estamos denominando Sistema Universidade Aberta do Brasil. 
Permite-nos compreender o fragmento que o texto faz parte de uma estratégia discursiva que tem origem no Projeto Universidade Aberta do Brasil que, portanto, lhe antecede. Representando o Projeto, desse modo, uma primeira instância de enunciação, responsável pela concepção da UAB que implica trabalho preparatório e planejamento, desenvolvidos por setores competentes e especializados. De sorte que o T1 passa a representar uma segunda instância de enunciação, destinada por seu turno a apresentar o Projeto Universidade Aberta do Brasil, suas bases e criação, bem como sua importância na consolidação do Sistema Universidade Aberta do Brasil.

Considerando que o sujeito do discurso é o mesmo da primeira e da segunda instância de enunciação, ao invés apenas de ter o sentido de expor ou dar a conhecer, o verbo apresentar acaba aludindo à tarefa reservada ao texto de preparar a adesão e o comprometimento dos setores interessados no Projeto $U A B$, antes mesmo de este ser implementado. Como requer qualquer processo de planejamento, muito mais ainda no âmbito das políticas públicas, isso pressupõe um trabalho de marketing voltado para garantir a necessária publicização, repercussão e aceitação do produto "UAB" junto à sociedade. Em se tratando de um discurso autoritário que já parte da presunção de sua importância [Projeto] na consolidação do Sistema $U A B$, o marketing assume maior relevância ainda, principalmente, porque cabe a ele, muitas vezes, produzir a opacidade do discurso.

Sob o predomínio dessa opacidade é que outras características da industrialização do ensino marcam a sdr 1. A organização é uma das principais a ser evocada, não sendo por acaso que a seqüência se vê atravessada pela referência, co-referência e paráfrase do substantivo projeto 
como símbolo, a um só tempo, do plano e do empreendimento de transformar em realidade a idéia da UAB. Os fragmentos que sublinhamos a seguir representam, por isso mesmo, vestígios importantes de uma formação discursiva caracterizada pela organização racional dos processos produtivos, em particular, de ensino e aprendizagem: programas TV Escola e Proinfo; programas de formação; projetos e programas; Projeto Universidade Aberta do Brasil (UAB); e, mais uma vez, Projeto Universidade Aberta do Brasil.

Signo também de um trabalho preparatório e do planejamento efetivo, a ênfase sobre a organização supõe, ainda, conceber a UAB do ponto de vista de uma estratégia de ação, nos moldes do caráter estratégico e da estratégia de trabalho colaborativo representados pela SEED. O que decorre de uma racionalidade que justifica, além disso, a alusão não apenas às bases e criação, como também à futura consolidação do Sistema $U A B$, indicando tratar-se de uma organização que se planeja tanto estrategicamente como em longo prazo, inclusive, estabelecendo de antemão suas formas de avaliação.

Embora referenciado uma única vez em meio à sdr 1, observamos que uma das ações estratégicas à SEED é o incentivo à pesquisa para o setor que remonta, em última instância, aos métodos de controle científico. Cruciais às políticas públicas tanto quanto o planejamento, cabe às pesquisas analisar o desempenho dos projetos e programas, com vistas a avaliar o cumprimento de objetivos e metas institucionais, bem como subsidiar a prestação de contas relativas aos seus resultados e impactos sociais. No caso da UAB não poderia ser diferente, assumindo a pesquisa o caráter [também] estratégico de efetuar, com base nos princípios de custo-benefício, eficiência, eficácia, produtividade, 
qualidade, entre outros, o controle rigoroso e permanente dos resultados obtidos durante toda a sua implementação e consolidação.

Esse controle serve, além do mais, para reforçar os níveis de formalização, padronização e objetivação típicos à produção industrial. Os enunciados regulamentação para educação a distância e Projeto Universidade Aberta do Brasil representam vestígios de uma racionalidade que transforma idéias e ações em projetos e programas formais, responsáveis por estabelecer previamente as diretrizes, metas e procedimentos a serem seguidos por todos os parceiros. Apesar de se colocar aberto ao diálogo ao apresentar o Projeto UAB, utilizando uma estratégia dialógica como já apontamos anteriormente, o sujeito do discurso refere-se na realidade a um projeto pronto e determinado por condições sócio-históricas anteriores que, portanto, pouco ou quase nada dependem da nova circunstância de enunciação em que se inscreve.

Paralelamente aos fragmentos de formalização, encontramos na sdr 1 traços característicos de um processo de padronização. Por um lado, faz-se alusão ao fato de a SEED constituir uma referência internacional, isto é, uma instituição à altura dos padrões internacionais em EAD, amplificando assim o seu caráter estratégico e sucesso alcançado na condução de projetos e programas. Por outro, seguindo essa mesma lógica de exemplaridade e exitosidade, faz-se menção à UAB como representando um modelo alternativo para a oferta e gestão de educação superior. A propósito, não qualquer modelo alternativo ao modelo presencial vigente no país, mas um modelo à altura dos padrões internacionais da Universidade Aberta e a Distância, testada, aprovada e consolidada em boa parte do mundo. 
Além de manifestar as características da formalização e da padronização, a sdr 1 vê-se afetada pela objetivação do processo de ensino-aprendizagem. Mesmo tendo em vista a democratização do acesso à educação superior pública, gratuita e de qualidade, conforme demonstram os fragmentos enfatizados a seguir, o sujeito do discurso é levado a conceber a UAB sob o prisma de uma estrutura complexa, na qual não há lugar para subjetividades. Até porque os sujeitos históricos convocados estão devidamente representados (para não dizer, assujeitados) pelas instituições as quais se encontram vinculados: rede nacional de educação a distância; Sistema Universidade Aberta do Brasil. Ele será formado pelas instituições federais de educação superior, em estreita relação com os Estados e Municípios, cristalizando a união de esforços das três esferas governamentais.

Os fragmentos nos ajudam a compreender, ademais, como a objetivação está associada a outras características da industrialização do ensino presentes na sdr 1 - concentração e centralização. Apesar da co-referência e da paráfrase se referir à mesma coisa, rede e Sistema não produzem um único efeito de sentido. A primeira remonta, sobretudo, a ideologia da integração nacional que, a todo custo, ganha força durante o Regime Militar, através de uma rede de telecomunicações, tornando-se fortemente atrelada à doutrina da segurança nacional. Ainda hoje, ela é evocada através da cadeia obrigatória de rádio e televisão formada para o "Pronunciamento à Nação do Excelentíssimo Senhor Presidente da República" e de outras "autoridades" ligadas aos poderes Executivo, Legislativo e Judiciário, além de se prestar à propaganda partidária e eleitoral.

Levando em conta a experiência estrangeira da "Universidade Aberta", o substantivo Sistema por sua vez 
seria redundante ou até desnecessário, não fosse sua razão de ser. Remonta ele os sistemas de EAD, essencialmente, caracterizados como organizações complexas, sob forte concentração de capital e centralização administrativa. Por essa razão, convém reiterarmos: Ele será formado pelas instituições federais de educação superior, em estreita relação com os Estados e Municípios, cristalizando a união de esforços das três esferas governamentais.

Como veremos agora através da análise do conjunto do T1, essas características típicas à iniciativa privada também afetam as políticas públicas, muito mais ainda, no contexto de um Estado neoliberal, racional por natureza, em que os discursos sobre desconcentração e descentralização caminham passo a passo aos processos de concentração e centralização. Vemos evidenciar-se, antes de tudo, que o discurso em torno do Sistema UAB reconhece a importância dos processos descentralizados. A ênfase sobre a consolidação e diversificação de experiências não deixa dúvida de que as novas ações devem ter como ponto de partida iniciativas já desenvolvidas.

O próprio emprego do verbo congregará, a princípio, dificulta-nos enxergar algum vestígio de discurso autoritário. Essa estratégia discursiva, porém, não se sustenta por muito tempo, entrando logo em contradição. Aquelas mesmas experiências antes enfatizadas acabam sendo questionadas, como representando tão somente ações que vêm ocorrendo de forma individualizada e não sistemática, com sobreposição de esforços e recursos. Além de promover a racionalização dos investimentos (isto é, sua concentração), cabe à UAB centralizar todas as iniciativas em torno de um Sistema, capaz de agregar e congregar, no sentido de administrar, gerenciar, coordenar, o conjunto das experiências. 
Na prática, o que se postula como consolidação e diversificação transforma-se em unificação das experiências, evocando assim outra característica do processo industrial - a padronização - que volta a se manifestar no T1. A nossa impressão inicial diante do texto é que se fala de um projeto pedagógico, a um só tempo, padronizado e não padronizado. No primeiro momento, o sujeito do discurso nos informa que o mesmo será unificado e que seu processo seletivo envolverá provas de Português, Matemática e Conhecimentos Gerais. No segundo momento, faz questão de ressalvar as particularidades de cada universidade em relação àquele mesmo projeto, além da condição autônoma para conduzir o processo de avaliação.

Esse jogo de linguagem, no entanto, serve para mascarar a ênfase sobre a padronização. Observando como se organiza hierarquicamente o próprio discurso, conseguimos perceber que o enunciado $O$ projeto pedagógico para o curso será unificado, mesmo aludindo a um fragmento que lhe antecede no segmento anterior - dezoito universidades federais [...] iniciarão os trabalhos para o desenho do projeto, deriva de um discurso autoritário que lhe força a anteceder qualquer observação relativa a outras particularidades ou polissemias. Notadamente, quando consideramos que aquele projeto diz respeito a um curso com oferta de dez mil vagas nacionais, o que difere de forma significativa do planejamento pedagógico circunscrito a uma instituição específica.

Do mesmo modo, posicionando-se em primeiro plano, o enunciado O processo seletivo constituir-se-á de provas de Português, Matemática e Conhecimentos Gerais não deixa margens para particularidades. A própria ressalva de que a instituição de ensino superior será autônoma para definir o modelo específico de avaliação não autoriza, automaticamente, 
o estabelecimento de um modelo particular. Como sabemos, o modelo de avaliação tradicionalmente adotado pelas comissões de vestibular das IFES, até por força da injunção de um processo seletivo, destina-se a selecionar os alunos com a melhor educação básica.

A referência à avaliação invoca outra característica da industrialização do ensino que incide sobre o T1 - a recorrência aos métodos de controle científicos. Os tópicos Alguns dados sobre oferta e atendimento na educação superior brasileira e Alguns dados sobre docentes e formação docente no Brasil representam, de antemão, uma profusão de parâmetros de análise de caráter extremamente racional, incluindo os seguintes exemplos: baixos indices de conclusão do ensino médio; indicadores que atendem ao disposto no Plano Nacional de Educação; Censo Escolar 2005; Esses números são relativamente mais amenos; perfil esse acima da média brasileira; desempenho dos estudantes nas avaliações realizadas pelo INEP/SAEB.

Os fragmentos que dizem respeito ao processo de avaliação e seleção dos pólos e cursos a distância são ainda mais ilustrativos de como os métodos de controle científicos afetam o T1, reforçando sua tendência à padronização e contrariando sua pretensão de se organizar como sistema aberto. A descrição detalhada dos critérios de análise e seleção representa forte indício de que o Sistema $U A B$ encontra-se submetido a um controle rigoroso. Acentua isso a reiteração, quase que literal, de uma série de fragmentos exemplares nesse sentido: carência de oferta, capacidade de oferta, quantitativo, infra-estrutura fisica, recursos humanos disponíveis e projeto pedagógico. Além deles, encontramos alusões a outros critérios tão ou mais importantes: adequação, conformidade, demanda, pertinência, cronograma de execução e localizações. 
Contudo, como se fosse necessário reforçar toda essa ênfase, o sujeito do discurso ainda acrescenta outro fragmento que não deixa de produzir o efeito de uma advertência:

Todas as propostas encaminhadas ao MEC serão analisadas e selecionadas por uma comissão de especialistas, tendo por critérios: consistência do projeto pedagógico e relevância do curso proposto, competência e experiência acadêmica da equipe docente responsável e coerência com a demanda da área geográfica de abrangência, atendimento da demanda do curso no pólo.

Logo em seguida, chama atenção o sujeito do discurso para a necessidade das IES, Estados e Municípios também se adequarem aos prazos estabelecidos com relação à participação no Sistema UAB. Consciente ou não, alude na realidade à outra característica do processo industrial - a formalização - que envolve o planejamento prévio e formal de cada etapa e de todo o ciclo de produção. Atravessando o T1 desde as alusões a regulamentações, propostas e projetos que culminam no Projeto/Sistema $\mathrm{UAB}$, a formalização afeta o discurso, de modo contundente, mediante os seguintes fragmentos: $A$ apresentação de propostas de projetos observará o seguinte cronograma: recebimento de propostas de 21 de dezembro de 2005 a 13 de abril de 2006; análise das propostas de 17 de abril a 30 de junho de 2006; divulgação dos resultados de 03 de julho a 07 de julho de 2006; e, finalmente, a formalização dos convênios aprovados de 10 de julho a 31 de agosto de 2006; No período de setembro de 2006 a 
fevereiro de 2007, serão realizadas as atividades para adequação dos pólos, preparação dos tutores, produção do material didático e demais ajustes; previsão de início dos cursos superiores para março de 2007.

Além de toda a tramitação das propostas de projetos, desde a sua apresentação, recebimento e conseqüente protocolização até a sua análise, divulgação dos resultados e formalização dos convênios, notamos que os procedimentos de formalização ainda são evocados pela produção do material didático, a previsão de início dos cursos superiores e demais ajustes que supõem a consideração daqueles de natureza formal. Essa ênfase sobre a formalização reforça, igualmente, a incidência sobre o texto de outra condição industrial, representada desta feita pelo trabalho preparatório.

Conforme observamos, a participação no Sistema $U A B$ envolve uma racionalidade institucional, administrativa e burocrática que pressupõe todo um esforço de preparação para se adequar aos seus critérios e prazos formais, mesmo numa fase de implantação em que a UAB será resultante da adesão voluntária. Sem se preparar racionalmente, seria difícil ao Sistema contabilizar quatrocentos e quatorze projetos de pólos de apoio presencial, bem como trinta e sete universidades federais e onze centros federais de educação tecnológica (Cefets) proponentes.

Conforme sugerem os últimos tópicos do T1, o Sistema em si já encerra um trabalho preparatório que tem início com O Projeto UAB no Fórum das Estatais pela Educação, evolui até $O$ Projeto-Piloto com o Banco do Brasil e $O$ Edital de Convocação das IES, Estados e Municípios para participarem da UAB, alcançando, finalmente, os Projetos encaminhados para avaliação. A alusão ao Projeto-Piloto, em particular, referencia a adoção de uma estratégia típica à organização industrial que costuma submeter a testes 
rigorosos a aceitabilidade e viabilidade de bens e serviços, antes de produzi-los e distribuí-los em larga escala. Como não deixa dúvida o sujeito do discurso, graças inclusive às parcerias, o Projeto-Piloto com o Banco do Brasil também sugere resultados promissores: dezoito universidades federais que já contam com infra-estrutura adequada para os cursos; iniciarão os trabalhos para o desenho do projeto pedagógico para o curso.

O Projeto-Piloto e mesmo todo o trabalho preparatório em torno da UAB fazem parte, em última instância, do processo de planejamento que constitui uma das características fundamentais à organização industrial. Ao longo do T1, encontramos um conjunto de vestígios que, a todo tempo, estão a lembrar que o Sistema UAB resulta de um plano baseado em condições sócio-históricas concretas e que, por isso mesmo, segue metas e procedimentos preestabelecidos, tanto racional quanto estrategicamente: questões estratégicas ligadas ao desenvolvimento sustentável do País; busca de solução para os problemas ligados à educação; ações de fomento e projetos voltados para a educação superior a distância.

Os enunciados que ressaltamos a seguir representam, melhor ainda, como o Sistema $U A B$ reporta-se a um processo de planejamento consideravelmente amplo e estratégico no âmbito do ensino superior que inclui desde a configuração de políticas, programas e projetos até o estabelecimento de metas e ações: A iniciativa integra importantes políticas públicas para a área de educação; programas voltados para a expansão da educação superior com qualidade e promoção de inclusão social; o projeto tem sido caracterizado pela reafirmação do caráter estratégico desse nível educacional, do desenvolvimento científico e da inovação tecnológica para o crescimento sustentado do país; metas e ações para a promoção da educação inclusiva e cidadã. 
O planejamento de um sistema com a amplitude da $\mathrm{UAB}$, por extensão, não pode ficar a cargo de um modelo simples de administração, mas submetido a uma gestão complexa, típica à organização industrial. Conforme indicam a princípio alguns fragmentos e enunciados, o sujeito do discurso reporta-se a uma estrutura sistêmica, com a autonomia necessária ao seu funcionamento e à participação eqüitativa dos participantes: desenvolvimento do trabalho de gestão da educação superior na dinâmica de rede, propiciando trabalho colaborativo para o desenvolvimento institucional; adesão voluntária de 55 universidades federais, além do conjunto de centros federais de educação tecnológica, articulados e integrados com a rede de pólos de apoio presencial para EAD.

Aprofundando a análise do T1, percebemos entretanto que o Sistema $U A B$ reproduz o modelo de administração tradicional, consolidado pela organização industrial moderna e ainda vigente no mundo contemporâneo. A recorrência a esse modelo encontra sua maior expressão por ocasião de uma analogia que o sujeito do discurso produz, ao discorrer sobre o Projeto-Piloto da UAB (a propósito, resultante de parceria especial do Banco do Brasil e demais bancos estatais que constituem empresas organizadas nos moldes convencionais, incluindo uma gestão verticalizada): Pretende-se que o sistema de biblioteca seja idealizado como uma Unidade de Informação.

Ao considerar o sistema de biblioteca como uma Unidade de Informação, o sujeito do discurso reporta-se ao modelo fundante da organização industrial - a Unidade de Produção. O que pressupõe que a idéia que elabora relativamente ao Sistema UAB como um todo, também, deriva do mesmo modelo. Daí podermos supor que, na verdade, o sujeito do discurso produz uma analogia nos seguintes termos: Pretende-se que o Sistema UAB seja idealizado como uma Unidade de Produção. 
O primeiro vestígio que encontramos nessa direção refere-se à estrutura da Unidade de Produção (leiamos Sistema $U A B)$. Logo de início, ela é subdividida, por seu turno, em duas unidades elementares à qualquer organização industrial - a unidade-base e as unidades-pólos: $a$ estrutura inicial do sistema deverá ser composta de uma unidade de informação-base (biblioteca-sede) e demais unidades de informação-pólos (bibliotecas nos centros regionais de desenvolvimento). Por extensão, isso significa referenciar a SEED/ MEC como sede e as IES e os pólos de apoio presencial (mantidos pelos Estados e Municípios) como centros regionais de desenvolvimento do sistema, sem deixarmos de levar em conta a participação de outras instâncias no processo (Fórum das Estatais pela Educação, demais secretarias e órgãos do $M E C$, novos e diferenciados partícipes, entre outros).

A não ser pelos indícios de formalização (unidade de informação-base no início e, mais adiante, demais unidades de informação-pólos), até essa altura não conseguimos entretanto apreender como se estrutura hierarquicamente a Unidade de Produção, isto é, de forma vertical ou horizontal. No transcorrer do texto é que começamos a encontrar fragmentos de uma tendência verticalizada, em conformidade com uma tradição cara à organização industrial. Antes e acima de tudo, caberá fundamentalmente à unidade-base responsabilizar-se pela definição e condução das politicas e diretrizes gerais do sistema, o que nos faz lembrar as ações que contribuem para a SEED consolidar-se como referência internacional e de caráter estratégico para a educação brasileira.

Como se o sujeito do discurso estivesse se referindo amplamente a uma Unidade de Produção e não mais apenas a uma Unidade de Informação, assinala ele que cabe às unidades-pólos por sua vez responsabilizar-se pela 
implementação, execução e manutenção do sistema. O que inclui desde o suporte informacional ao ensino, acesso aos conteúdos pedagógicos e às tecnologias de informação pertinentes até o apoio aos sistemas de tutoria presencial e a distância, fazendo-nos recordar o compromisso inalienável dos parceiros de projetos. Em outras palavras, enquanto a SEED assume importância capital ao sistema, ligada inclusive ao postulado de que a educação superior conforma-se como estratégia basilar para o desenvolvimento nacional sustentável, as IES e os pólos de apoio presencial ocupam uma relevância secundária, em atendimento a metas básicas para o desenvolvimento regional sustentável.

A recorrente alusão ao desenvolvimento nacional e ao desenvolvimento regional ajuda-nos a compreender, igualmente, a incidência no T1 de outra condição "sine qua non" ao processo industrial - a produção de massa. Sem apoio de uma oferta de ensino em grandes proporções, praticamente, seria impossível planejar e consolidar um sistema de educação a distância capaz de enfrentar os desafios dos baixos níveis de atendimento na educação superior, da concentração da oferta nos grandes centros, e das limitações do modelo vigente de financiamento. Desde a sdr 1, observamos que o texto é constantemente perpassado por um enunciado-síntese de todo um discurso em torno da UAB: democratização da educação superior e formação inicial e continuada de professores.

Produção de massa como forma de democratização do ensino

Dois enunciados, em especial, lançam vestígios dessa característica industrial sobre a sdr 1: oferta e gestão de educação superior e democratização do acesso à educação superior. Precisamos compreender, notadamente, que oferta e gestão e democratização não se traduzem por meio de um único 
sentido. A primeira expressão alude, diretamente, à produção de massa, caracterizada pela gestão racional de bens e serviços em larga escala e cuja oferta é organizada na proporção do contingente e das demandas específicas dos consumidores. No que diz respeito ao Sistema $U A B$ de acordo com as potencialidades e demandas nacionais de acesso à educação superior, daí se entender por que o sujeito do discurso faz questão de retomar Alguns dados sobre a formação docente e em nível superior no país.

O substantivo democratização, apesar de estar associado a acesso que também remete à produção de massa, alude em parte à outra formação discursiva, representada pela educação superior pública, gratuita e de qualidade. Recorre, dessa forma, ao princípio que inclui a educação entre os direitos e garantias fundamentais ao cidadão, o que transcende as chamadas leis de mercado, estabelecidas a partir das condições concretas e materiais de oferta e procura. Como esclarece Khôi (1970, p.256), devemos definir "a democratização não pela igualdade teórica de acesso ao ensino, mas pela igualdade efectiva das possibilidades dadas a cada pessoa de desenvolver todas as suas faculdades".

Acontece que, conforme já nos advertia Peters (2003b, p.92), em países extensos como o nosso em que as demandas pressupõem "mass higher education", a democratização da universidade não pode ser pensada senão em termos de atendimento de massa, "sequer é possível sem esse tipo de oferta de ensino." O que nos permite entender porque, na realidade, para o sujeito do discurso não representa contradição alguma associar nem tampouco aproximar oferta e gestão de democratização. Essa aproximação não se dá apenas através dos fragmentos sublinhados, mas a partir de uma relação estabelecida entre quatro enunciados, 
referenciados entre o segundo e o terceiro segmento da sdr 1: Projeto Universidade Aberta do Brasil, modelo alternativo para a oferta e gestão de educação superior, Sistema Universidade Aberta do Brasil e democratização do acesso à educação superior pública, gratuita e de qualidade.

A relação entre os enunciados se estabelece em dois momentos - no interior de cada segmento através de parafrasagem e, no âmbito dos dois segmentos, mediante o emprego de uma espécie de cadeia de referência. No segundo segmento da sdr 1, observamos uma relação em que o enunciado modelo alternativo para a oferta e gestão de educação superior, ao mesmo tempo, alude e parafraseia o referente Projeto Universidade Aberta do Brasil. Até então representando (inclusive, confundindo-se com o referente ano de 2005) um marco histórico para a educação a distância no País, o Projeto ganha um novo sentido que referencia sua importância agora como modelo alternativo ao modelo convencional de oferta e gestão de educação superior - conforme lembra uma determinada memória discursiva - caracterizadamente presencial.

No terceiro segmento da sdr 1 , notamos uma relação em que o enunciado democratização do acesso à educação superior pública, gratuita e de qualidade, igualmente, faz menção e serve de paráfrase ao referente Sistema Universidade Aberta do Brasil. Até então concebido como representando a rede nacional de educação a distância, além de agregar um segundo sentido - o de, sugestivamente, cristalizar a união de esforços das três esferas governamentais, o Sistema adquire um terceiro significado. Reportando-se este à democratização do acesso à educação superior pública, gratuita e de qualidade - conforme, também, lembra uma determinada memória discursiva - tradicionalmente elitista. 
O estabelecimento da relação entre os enunciados por intermédio de uma espécie de cadeia de referência, por sua vez, incide sobre os dois segmentos a um só tempo. Consideramos, por um lado, que ao pronunciar Sistema Universidade Aberta do Brasil o sujeito do discurso evoca, quase que de imediato, Projeto Universidade Aberta do Brasil e vice-versa, devido ao fato inclusive de um enunciado pressupor o outro. Por outro lado, ao mencionar democratização do acesso à educação superior pública, gratuita e de qualidade o sujeito do discurso alude, de forma quase automática, modelo alternativo para a oferta e gestão de educação superior, enunciado com o qual mantém uma relação de aproximação muito forte.

Examinando os enunciados no seu conjunto, percebemos que a relação estabelecida entre os mesmos é de causa e efeito, ou melhor, entre meios e fins. Enquanto Projeto, a Universidade Aberta do Brasil constitui instrumento estratégico para propor um modelo alternativo para a oferta e gestão de educação superior. Enquanto Sistema, a UAB representa iniciativa sem precedentes para garantir a democratização do acesso à educação superior pública, gratuita e de qualidade. Em suma, os enunciados se encadeiam para reiterar que, seja na forma de Projeto seja na forma de Sistema, a UAB encerra, por excelência, um modelo alternativo para a gestão e democratização da educação superior pública, gratuita e de qualidade.

Ao longo do T1, esse postulado é retomado através de uma alusão constante ao enunciado-síntese democratização da educação superior e formação inicial e continuada de professores. Dois tópicos do texto, inclusive, são direcionados nesse sentido: Alguns dados sobre oferta e atendimento na educação superior brasileira e Alguns dados sobre docentes e formação docente no Brasil. Além disso, os fragmentos que 
evocam o enunciado-síntese são por demais recorrentes, incluindo desde aqueles que são reiterados até aqueles que acabam formando uma extensa família parafrástica: acesso ao conhecimento e aos níveis mais elevados de educação; expressiva demanda por formação superior inicial e continuada; democratização do acesso ao ensino superior; expansão da educação superior com qualidade e promoção de inclusão social; educação superior para todos, com qualidade e democracia; oferta de educação superior por meio da modalidade de educação a distância.

Essa recorrência sistemática ao enunciado-síntese induz o sujeito do discurso, por um lado, a mobilizar como contraponto fatos que corroboram a debilidade, fragilidade, ou melhor, uma espécie de irracionalidade da formação superior e continuada no país. Em outras palavras, uma realidade que não deixa dúvidas sobre a elitização da educação superior e formação inicial e continuada de professores no Brasil. De sorte que encontramos um conjunto de enunciados que reiteram os problemas e desafios enfrentados na área: baixos índices de acesso à educação superior; número insuficiente de vagas no setor público; forte desigualdade de acesso ao ensino superior, em especial, da população menos favorecida economicamente; discrepâncias regionais marcantes.

A irracionalidade da formação superior e continuada no país ganha maior relevância, contudo, à medida que são acentuados os seus déficits em termos estatísticos: apenas 10,5\% da população brasileira, com idade entre 18 e 24 anos de idade, têm acesso à educação superior, valor inferior ao de países como a Argentina (40\%), Venezuela (26\%), Bolívia $(20,6 \%)$ e Chile $(20,6 \%)$; demanda reprimida por vagas, acarretada pela concentração da oferta em praticamente $30 \%$ dos nossos municípios; Dos 2,9 milhões de funções docentes, cerca 
de 1,1 milhão, ou 38,1\%, não têm licenciatura completa. O que nos permite compreender que o sujeito do discurso não recorre aleatoriamente a essas estatísticas; pelo contrário, busca a partir delas consubstanciar e legitimar uma ação (Sistema UAB) que não apenas se mostra estratégica, como também requer ser aplicada em larga escala.

Por outro lado, mobilizando como ponto de apoio fatos que demonstram a potencialidade ou racionalidade da democratização da educação superior e formação inicial e continuada de professores no Brasil, o sujeito do discurso evoca dois tipos de demandas que acometem o país. Muito embora não sejam excludentes e, muitas vezes, mantenham relações intrínsecas, essas necessidades caracterizam-se como profissionais e geográficas, destacando-se em meio a estas últimas os seguintes enunciados: capilarização e interiorização da oferta; atendimento das demandas nacionais reprimidas; aumento da oferta nas regiões distantes dos grandes centros; demanda local ou regional por ensino superior público. Essas demandas tornam-se ainda mais incisivas à medida que o sujeito do discurso lança mão de fragmentos que se reportam a fatos e números que, dificilmente, seriam alcançados senão mediante um sistema de educação a distância capaz de suprir, plenamente e em tempo recorde, necessidades do país como um todo: quatrocentos e nove municípios proponentes, totalizando quatrocentos e quatorze projetos de pólos de apoio presencial, em todas as vinte e sete unidades da federação; trinta e sete universidades federais e onze centros federais de educação tecnológica (Cefets) proponentes.

Além das demandas geográficas, o sujeito do discurso recorre a fragmentos e enunciados que fazem alusão a demandas profissionais, também, importantes para reforçar o caráter racional e urgente tanto da formação em 
nível de licenciatura como da construção e execução de amplo programa nacional de formação em serviço, para os servidores públicos, tendo em vista a enorme demanda desse tipo de formação nas esferas estaduais e municipais. Os indícios que destacamos a seguir são veementes nesse sentido, revelando como o sujeito do discurso justifica e até naturaliza a implantação do Sistema $U A B$ em razão das demandas profissionais vigentes no país: parece natural supor que devemos traçar politicas públicas que visem levar a formação em nível superior - com qualidade - a todos os professores que atuam ou que venham atuar na educação infantil, fundamental ou média; Não obstante os diversos programas e ações coordenados pelo MEC nos últimos anos terem contribuído bastante para melhorar o quadro geral de formação de professores no Brasil, os números aqui mostrados - em conjunto com a complexidade social, econômica e geográfica indicados anteriormente - revelam que é grande o desafio de se constituir um sistema educacional que garanta o acesso de todos ao conhecimento e aos niveis mais elevados de educação preconizado no Texto Maior.

Aqui o próprio sujeito do discurso provoca a descontinuidade deste, pelo menos, até quando passamos a compreender que o "outro" discurso por ele mobilizado é mais complementar do que antagônico. Não há dúvida de que os diversos programas e ações coordenados pelo MEC nos últimos anos são questionados e relativizados, como não tendo sido tão eficazes. Essa ineficácia, ao invés de produzir o efeito de uma contradição, é empregada muito mais como pretexto para o sujeito do discurso justificar a adoção das [novas] medidas criadas por parte do Ministério da Educação, cuja racionalidade desta feita se coloca a toda prova: o desenho proposto para o Sistema Universidade Aberta do Brasil, apresenta forte potencial de solução para esse quadro. 
O potencial de solução aí aludido não trata, portanto, de qualquer potencial, mas daquele forte o bastante para garantir efetivamente a democratização da educação superior e formação inicial e continuada de professores. O que precisamos entender, todavia, é que a democratização que o sujeito do discurso evoca não tem um fim em si mesmo, pelo contrário, somente ganha sentido à medida que é relacionada a sua finalidade mais ampla, representada pelos efeitos da expansão da formação superior e continuada na sociedade contemporânea:

Trata-se de um marco histórico para a educação brasileira e que será amalgamado na produção coletiva de iniciativas compatíveis com a necessidade de revigoramento do modelo de formação superior no Brasil - tradicionalmente baseado em formação acadêmica inicial - e no repensar a educação ao longo da vida.

Outros fragmentos nos ajudam a perceber, melhor ainda, que um projeto de democratização da formação superior e continuada que tem como finalidades responder à emergência de novas competências para o trabalho, provocadas pelos constantes avanços tecnológicos, novo modelo de desenvolvimento econômico brasileiro e desafios impostos pela sociedade global e do conhecimento, apenas e tão somente, pode ser pensado nos marcos de um sistema de produção de massa. De um sistema, por um lado, capaz de universalizar tanto a formação inicial como a formação continuada ao longo da vida, garantindo o acesso de todos ao conhecimento e aos níveis mais elevados de educação preconizado no Texto Maior. Por outro, capaz de atender às progressivas e 
profundas reestruturações das relações profissionais que forçam, obrigatoriamente, a adoção de políticas públicas que visem levar a formação em nível superior - com qualidade - a todos os professores que atuam ou que venham atuar na educação infantil, fundamental ou média.

Teoria pós-industrial e teoria do capital humano (ALMEIDA, PEREIRA, 2000; PAIVA, 2001; SAUL, 2004) parecem se juntar em um mesmo discurso - que vai do Texto Maior ao T1, retomando e desencadeando outros infinitos textos - em favor da democratização da educação superior e formação inicial e continuada de professores. A evidência dessa justaposição nos é possível, mais precisamente, à medida que o sujeito do discurso faz questão de fazer a seguinte ressalva à UAB: Em relação à flexibilidade curricular, deverá ser adotado um conjunto de procedimentos visando orientar o aluno na escolha de uma trajetória adequada à sua disponibilidade tempo de estudo e sua formação anterior. A flexibilidade não deixa de aludir a um Sistema destinado à produção de massa que necessita se adaptar, sistemática e constantemente, às demandas contemporâneas da sociedade industrial e de consumo.

\section{Continuidades e regularidades do discurso industrial}

Apesar de apresentado como um marco histórico para a educação a distância no País, o Sistema UAB não representa o único nem tampouco o primeiro programa do governo federal que visa a democratização da educação superior e formação inicial e continuada de professores. Na realidade, o programa retoma um ideal que atravessa, pelo menos, as últimas seis décadas de história do Estado brasileiro, mantendo-se fortemente presente ao longo de toda a evolução da política nacional de EAD. O que o faz transitar e 
transcender, durante esse período, tanto as configurações assumidas pelo Estado (Estado Providência, interventor, neoliberal etc.) como as orientações político-ideológicas de cada governo (populista, militar, democrático etc.).

Conforme veremos a partir da análise do conjunto do corpus discursivo, trata-se de um ideal que não apenas traduz a prevalência de uma característica (produção de massa), como também faz alusão a outras condições estruturais que marcam a incidência do discurso da industrialização do ensino sobre a política de EAD. A primeira evidência disso se dá quando comparamos o enunciado-síntese do T1 àqueles que poderíamos chamar enunciados-sínteses dos demais textos, ainda que tomemos como referência, no caso destes últimos, apenas a sdr selecionada: T2) democratização e melhoria da qualidade da educação pública brasileira; T3) treinamento de professores; T4) formação inicial e continuada do cidadão brasileiro; T5) formação e reciclagem de professores; T6) qualificação; T7) democratizar o sistema educativo, orientando-o no sentido de contribuir para a correção das injustiças e discriminações; T8) proporcionar universal oportunidade de educação no Brasil inteiro; T9) promoção de tal educação em massa; T10) na luta pela disseminação da instrução, bem como na promoção do treinamento profissional.

Percebemos, de antemão, que o enunciado-síntese do T1 retoma duas questões centrais aos demais textos, a saber, a universalização da educação (reatualizada como democratização da educação superior) e a qualificação profissional (reatualizada como formação inicial e continuada de professores). A primeira questão remonta os textos 2, 4, 7, 8 e 9, não restando dúvida de que a universalização aí postulada acaba fazendo prevalecer a produção e oferta de uma educação em massa. À exceção de um texto dos anos 1960 que ainda se permite utilizar da expressão educação 
em massa, a transparência do discurso nos demais textos cede lugar a um jogo de linguagem que atribui a determinados termos e expressões (democratização, formação, democratizar, universal oportunidade e promoção) a capacidade de dar sentido àquilo que interessa ao sujeito do discurso.

A segunda questão remonta, por sua vez, os textos 3, 5 e 6, não havendo dúvida de que a qualificação aí pretendida faz prevalecer o treinamento e a reciclagem, também, em massa. Não encontramos exceções aqui, até porque desde os anos 1970 o discurso sobre a preparação para o mercado de trabalho costuma empregar a mesma objetividade: treinamento, qualificação, formação e reciclagem. Processos que se dão, principalmente, no contexto da produção e oferta de uma educação profissional destinada a grandes contingentes de trabalhadores, seja da esfera privada seja da esfera pública, como é o caso dos professores da rede pública de ensino.

Mais interessante, ainda, é observarmos que o enunciado-síntese do T1 retoma, em grande medida, o enunciado-síntese do T10. Quase seis décadas depois, é como se a democratização da educação superior e formação inicial e continuada de professores produzisse como efeito de sentido representar mais um esforço na luta pela disseminação da instrução, bem como na promoção do treinamento profissional. No entanto, o sujeito do discurso ignora, ou mesmo, faz questão de apagar essa memória discursiva, a ponto de considerar o Sistema UAB como um marco histórico para a educação a distância no País, portanto, um esforço sem precedentes e definitivo.

Cabe à memória discursiva, não obstante, exercer um papel importante no sistema de enunciabilidade que faz prevalecer o discurso da produção de massa no corpus em estudo. Em todos os textos, o sujeito do discurso sempre 
está a evocar uma educação produzida em larga escala, objetivando alcançar segmentos amplos da população ou do sistema de ensino. Essa recorrência, aliás, não se resume aos enunciados-sínteses, mas envolve uma série de fragmentos e enunciados que não aparecem aleatoriamente em meio aos textos.

Os textos, antes de tudo, são marcados por uma alusão constante à EAD como produção de massa. A recorrência aos enunciados TV Escola, Radiodifusão Educativa, teleducação, instrução pelo rádio e televisão, instrução por TV e ensino por correspondência mobiliza uma memória discursiva que concebe a educação como ofertada por intermédio de tecnologias ou meios de comunicação, caracterizadamente, de massa (correios, rádio, televisão etc.). A própria evolução da expressão escola à distância da sdr 10 para educação a distância da sdr 1 evidencia não exatamente um processo de desinstitucionalização, mas de amplificação e mesmo superação das fronteiras da escola ou da educação presencial, reafirmando a idéia de não haver limites para a expansão do ensino industrializado.

Essa idéia de massificação típica à EAD, de fato, acompanha o discurso em torno da política de educação a distância, desde os anos 1950. Ali já encontramos fragmentos e enunciados que, por um lado, evocam a intensidade de aplicação da EAD: amplamente utilizado; em numerosas regiões do globo; milhões e milhões de pessoas, anualmente, iniciam e prosseguem estudos. Por outro, aludem à amplitude de seu alcance: A todos esses, assim como a diversos outros grupos; é que a escola vai, sob a forma de ensino por correspondência, ministrando-lhes, não só instrução acadêmica dos três níveis (primário, secundário e superior), mas também treinamento profissional de vários graus e categorias. Não vemos aí, é bom frisarmos, menção a individualidades, mas uma 
série de alusões a coletividades, seja na forma de regiões ou de grupos de pessoas, seja na forma de níveis de educação ou treinamento.

Nos anos 1960, como destacamos acima, a idéia da massificação é inclusive referenciada diretamente, através do enunciado-síntese da sdr 9 - promoção de tal educação em massa. Mas outros fragmentos e enunciados reforçam esse discurso por meio de parafrasagem, tanto ao nível daquela seqüência como da sdr 8: impacto total em uma nação; aumentará grandemente o número de estudantes a receberem boa educação, especialmente em áreas rurais; maiores oportunidades para educação de mulheres; podem vir a ser usados nas escolas de todo o Brasil; uma solução para o problema educacional do país. Mais incisivas, ainda, são as seguintes alusões que revelam um sujeito do discurso significativamente afetado pela produção de massa: era da educação e da alfabetização universais e tornar o Brasil capaz de usufruir as vantagens de oportunidade universal de educação, no futuro próximo, a um custo razoável.

Melhor síntese de que a produção de massa continua prevalecendo nos anos 1970 são duas referências que se completam. Através da sdr 6, evoca o sujeito do discurso o alto indice que uma clientela específica, por força de dificuldades de comunicação, acesso e infra-estrutura, demanda em termos de qualificação profissional: cerca de 150 a 200 mil professores leigos, em exercício do magistério nas quatro primeiras séries do ensino de $1^{\circ}$ grau, em todo o território nacional. Antes mesmo disso, mediante a sdr 7, faz alusão aquele sujeito ao Projeto Nacional de Teleducação que tem em vista a própria universalização do ensino. Já antevendo o que vai ser retomado nos anos 2000 por parte do T1, como vimos anteriormente, essa universalização encontra-se atrelada tanto às exigências do desenvolvimento nacional como da 
sociedade pós-industrial: adaptadas ao estágio de desenvolvimento do País, permitindo assim maior amplitude e flexibilidade ao processo educacional; hão de fazer da escola do futuro uma estrutura mais aberta e flexível, oferecendo a todos oportunidades de formação segundo suas capacidades.

Essas exigências, até por força da emergência da globalização da economia, mantêm-se presentes nos anos 1980. Em meio à sdr 5, observamos fragmentos e enunciados que se reportam desde o apoio ao pré-escolar e o cumprimento curricular do Supletivo de $1^{\circ}$ e $2^{\circ}$ graus até o desenvolvimento de ações sócio-educativas e culturais que não deixam de aludir ao processo de mundialização da cultura e da expansão da chamada sociedade da informação e do conhecimento. A ênfase do sujeito do discurso recai, entretanto, sobre a própria complexidade e amplitude do Sistema Nacional de Radiodifusão Educativa. Apesar de ser integrado hoje por 14 emissoras de televisão, 340 repetidoras de televisão e 22 emissoras de rádio educativas que alcançam 300 municípios em todo o País, com audiência estimada de 32 milhões de pessoas, o que se encontra em questão é o fortalecimento desse sistema: A consolidação, o aperfeiçoamento e a expansão da televisão e do rádio Educativos. Do que decorre que a recepção organizada reivindicada para um sistema com tal magnitude não poderia ser outra senão nos moldes da produção de massa.

Durante os anos 1990, o atendimento dessa recepção organizada em forma de massa constitui uma preocupação central. Examinando a sdr 4, o que vamos perceber é que a capacitação da força de trabalho nacional, em especial dos professores da educação básica passa, inclusive, por essa orientação. Cabe ao Programa Nacional da Educação à Distância promover a ampliação da rede de escolas equipadas, no sentido de atender à clientela do ensino fundamental: 
alunos, professores e gestores. Considerando agora a sdr 3, através da qual o sujeito do discurso faz questão de lembrar que o que estávamos fazendo, paulatinamente, era ir treinando as pessoas e ir conquistando os professores para o uso da TV Escola, esse universo já atinge 50 mil escolas em todo o Brasil, chegando a resultados não menos exitosos: Com apenas um ano de funcionamento a TV Escola tinha $75 \%$ dos equipamentos funcionando, em uso na sala de aula, com alguma utilização no treinamento de professores, ou seja, com alguma utilização pedagógica. Hoje, temos muito mais.

A alusão à recepção organizada, ou mesmo, utilização pedagógica da TV Escola e outros programas de EAD permanece sendo enfatizada nos anos 2000. Na sdr 2, encontramos fragmentos e enunciados que reforçam a sua importância inclusive para enriquecer o ensino presencial junto à escola pública do país, o que remete a um sistema educativo de dimensões continentais. Não esquecendo de situar tais ações no contexto de uma política e de programas de abrangência nacional, evoca o sujeito do discurso ademais o aperfeiçoamento e capacitação de professores do ensino básico, antecipando aquele mesmo desafio que no T1 atribui ao Sistema Universidade Aberta do Brasil equacionar.

Os fragmentos de intertextualidade e, melhor ainda, de interdiscursividade da industrialização do ensino presentes ao longo do corpus discursivo não se restringem às reiterações à produção de massa. A esta se associam outras características que demonstram como o sujeito do discurso é afetado, a todo momento, por uma formação discursiva que insiste em prevalecer frente à história. $\mathrm{O}$ que significa que, ao encontrarmos vestígios no T1 do trabalho preparatório, planejamento, organização, métodos de controle científicos, assim por diante, deparamo-nos muitas vezes com recorrências que já incidiram sobre outros textos. 
Destaca-se, nesse sentido, o fato de todos os textos evocarem a centralização administrativa. A mesma SEED que ganha relevo no T1, como examinamos anteriormente, já prevalece na sdr 2, representando uma estrutura de governo vinculada ao Ministério da Educação responsável por uma política de EAD, em plena década de 2000, fortemente centralizada. Apesar de a SEED ser referenciada indiretamente através das inúmeras recorrências à $T V$ Escola, na sdr 3 ela cede lugar ao Ministério da Educação, mesmo porque - convém acentuarmos - o locutor da ocasião é o próprio ministro, o que só fortalece a centralidade do discurso. Através da sdr 4, porém, vamos observar que o MEC já se encontra representado pela SENEB, a Secretaria Nacional de Educação Básica, o que remete ao fato de a política de EAD, nos anos 1990, concentrar-se no âmbito do ensino fundamental e médio.

Os anos 1980, por sua vez, são marcados por uma referência quase que literal à centralização administrativa. Acontece que, desta feita, a sdr 5 é atribuída ao próprio último presidente do Regime Militar que não parece medir as palavras para dar sentido a uma das estruturas de comando daquele governo, a FUNTEVÊ: A Fundação Centro Brasileiro de Televisão Educativa, criada pela Lei $n^{o}$ 5.198/67, tem coordenado as atividades no âmbito das tecnologias educacionais, concentrando os planos e a administração destas técnicas dispersos até 1982.

A centralização da política de EAD, porém, já se faz presente ao longo dos anos 1970, graças inclusive à plena vigência do Regime Militar. Por um lado, conforme observamos através da sdr 6, cabe ao DSU/MEC (Departamento de Ensino Supletivo) ocupar essa centralidade, razão que explica porque o sujeito do discurso evoca a sua pronta diligência: O Departamento resolveu então partir para uma 
ação supletiva na tentativa de resolução do problema. Por outro, como demonstram de modo particular dois fragmentos da sdr 7, compete ao Ministério da Educação e Cultura assumir diretamente essa condição: motivos que levaram o MEC a incluir, entre os projetos prioritários do Plano Setorial de Educação e Cultura 1972/74, o Projeto Nacional de Teleducação ( $\left.N^{0} 36\right)$, com o objetivo de coordenar, integrar e sistematizar a utilização das tecnologias educacionais; Com o novo Plano Setorial para 1975/79, extingue-se o Projeto $N^{0} 36$, substituído pelo Projeto $N^{0} 7$. Se os verbos de ação coordenar, integrar e sistematizar já invocam um sujeito agente, incluir e extingue-se referem um poder de deliberação que não deixa dúvida sobre o fato de se encontrar acima de outras instâncias.

Algo semelhante se dá durante os anos 1960, período em que a educação a distância já faz parte das preocupações centrais do Conselho Nacional de Pesquisas, o antigo $\mathrm{CNPq}$ que centraliza então a política nacional de ciência e tecnologia. Vestígio importante, nesse sentido, é o seguinte fragmento que encontramos em meio a sdr 8: Em 1966 a Comissão Nacional de Atividades Espaciais (CNAE) iniciou um estudo e, em 1967, propôs medidas a serem tomadas pelo Conselho Nacional de Pesquisas visando a uma solução para o problema educacional do país. Embora a sdr 9 não faça referência direta a um órgão específico de comando, ao aludir que o plano educacional deve proporcionar um programa devidamente equilibrado, o sujeito do discurso acaba invocando, por excelência, o Ministério da Educação e Cultura. Cabendo ao MEC, desta feita, tomar medidas objetivando melhor organização e mais homogeneidade no sistema de educação com maior participação da comunidade. A participação aí aludida, decerto, deriva de uma estratégia discursiva voltada para ocultar o processo de endurecimento do Regime Militar. 
A sdr 10, também, não se refere a um eventual órgão de comando, porém nos oferece pistas significativas para compreendermos como a centralização administrativa já incide sobre a política de EAD, nos anos 1950: o que os alemães chamam de "escola à distância" (Fernschule); Graças a êle, em numerosas regiões do globo, como sejam, entre outras, os Estados Unidos e a Rússia, a Inglaterra e a Commonwealth, a França e a Alemanha, os Países Escandinavos e o Japão, milhões e milhões de pessoas, anualmente, iniciam e prosseguem estudos. Quando associamos a esses fragmentos o enunciado importantíssimo e eficaz instrumento, que não pode ser abandonado e que cumpre, muito pelo contrário, estimular e desenvolver, percebemos que esta última expressão invoca uma estrutura de governo que, a exemplo daqueles países, cuida em administrar, direta ou indiretamente, a escola à distância, atribuindo quase sempre papel central aos ministérios da Educação.

Considerando que o estímulo e o desenvolvimento da EAD também implicam na alocação de investimentos, o enunciado acima evoca outra característica da industrialização do ensino que, modo geral, acompanha a centralização administrativa - a concentração de capital. Muito embora não incida sobre todos os textos, já na sdr 10 encontramos dois fragmentos que aludem a essa concentração. Tanto em faltam recursos educacionais adequados como em pobreza de meios, percebemos uma referência, ainda que indireta e não exclusiva, ao papel do Estado como provedor essencial de recursos materiais e financeiros indisponíveis a uma parcela significativa da sociedade.

Além da década de 1950, a recorrência a um Estado provedor ou concentrador de recursos alcança os anos 1960. Mediante a sdr 9, observamos que uma das preocupações de então é oferecer alguma instrução formal para 
desistentes e para alunos que não têm recursos para instrução secundária. Apesar de mencionar os multi-bilhões de dólares de esfôrço espacial, numa alusão aos investimentos dos países desenvolvidos, a sdr 8 refere-se a um contexto em que os recursos se mostram limitados, exigindo sua maior concentração: custo baixo e com elevada confiabilidade; capabilidade de distribuir, a baixo custo; oportunidade universal de educação, no futuro próximo, a um custo razoável.

Recorrência semelhante à concentração de recursos dá-se durante os anos 1970. Por um lado, a sdr 7 reporta-se a dois projetos que parecem concentrar as dotações orçamentárias destinadas à política de EAD: Projeto Nacional de Teleducação ( $\left.N^{o} 36\right)$ e Projeto $N^{0} 7$. Por outro, encontramos em meio à sdr 6 dois enunciados que não deixam dúvida sobre o esforço de gerir os recursos a partir de projetos capazes de racionar as despesas e concentrar sua aplicação: qualificação de professores, à distância, sem retirá-los da sala de aula; o Projeto LOGOS I voltou-se para os estados da Paraíba e Piauí e territórios federais de Roraima, Rondônia e Amapá.

Igualmente à centralização administrativa, a concentração de recursos apresenta-se mais evidente durante os anos 1980. No entremeio da sdr 5, além do Sistema Nacional de Radiodifusão Educativa, encontramos referência à Fundação Centro Brasileiro de Televisão Educativa que tem coordenado as atividades no âmbito das tecnologias educacionais, concentrando os planos e a administração destas técnicas. Nos anos 1990, o sujeito do discurso volta a se referir à concentração de forma indireta. Enquanto na sdr 4, alude que a SENEB está fomentando ações junto as instituições governamentais e não-governamentais que constituem o Programa Nacional da Educação à Distância, indicando o controle daquele órgão sobre ações que podem envolver 
investimentos financeiros; na sdr 3, evoca o fato de que $o$ investimento que realizamos foi realmente pequeno, sugerindo o verbo realizamos a concentração de tal investimento junto ao próprio MEC.

$\mathrm{Na}$ linha da estratégia discursiva adotada no T1, encontramos na sdr 2 o seguinte fragmento, cuja intenção parece ser produzir como efeito de sentido uma espécie de desconcentração dos recursos destinados à política de EAD, nos anos 2000: A Secretaria de Educação a Distância, em sintonia com estados e municípios, vem, desde então, realizando investimentos significativos em uma infra-estrutura tecnológica. Apesar de indicar, à primeira vista, o incremento e uma maior distribuição dos investimentos entre as três esferas governamentais (tão evocadas na sdr 1), a assertiva não esconde, por outro lado, reportar-se ao conjunto da estrutura de governo responsável pela concentração dos recursos públicos.

Em decorrência inclusive da concentração dos recursos, centralização administrativa e produção de massa, três outras características da industrialização do ensino afetam conjuntamente o corpus discursivo - formalização, padronização e objetivação. Antecedendo sua ocorrência expressiva junto ao T1, logo observamos no entremeio da sdr 2 um grupo de fragmentos que se reportam à formalização das ações em EAD: politica; programas; projeto; Projeto Ipê; programa de atualização dos professores ingleses; programação de alta qualidade. Estes dois últimos, por sinal, fazem alusão à padronização de tais ações, buscada muitas vezes em padrões estrangeiros. Quando associado ao enunciado realizando investimentos significativos em uma infra-estrutura tecnológica, o conjunto dos fragmentos acaba reforçando a incidência da objetivação dos processos de ensino e aprendizagem, nos anos 2000. 
Objetivação, padronização e formalização fazem-se mais presentes, ainda, durante os anos 1990. Aludindo fragmentos como programas, lançarmos a idéia de criar esse programa, programa de treinamento de professores e lançado esse programa, a sdr 3 não apenas se reporta a um processo de objetivação, como também de formalização, principalmente, quando levamos em conta também o enunciado relatório do Nepp. A padronização é evocada, por sua vez, através de fragmentos como Seminário Internacional, sucesso, $100 \%$ de audiência e $100 \%$ de utilização, aceitação plena e imediata que remetem a padrões de qualidade norteadores daqueles programas.

A alusão a tais características é mais intensa quando consideramos a sdr 4, onde a incidência de cada uma delas parece se dar concomitantemente às demais: Programa Nacional da Educação à Distância; Programa UM SALTO PARA O FUTURO; Projeto Professor Alfabetizador; Projeto Complementação Pedagógica; Projeto Alfabetizar é Construir; Projeto Sistema de Apoio Tecnológico à Educação; programas de interesse do setor educacional; projetos de teleducação-telemática. A reiteração de projeto e programa não deixa dúvida sobre o grau elevado de formalização e objetivação das ações vinculadas à política de EAD, cujo processo de padronização é acentuado pelos enunciados Sistema de Apoio Tecnológico à Educação, Rede Brasil e rede de escolas equipadas que referem estruturas concebidas de acordo com padrões consideráveis de uniformidade.

Vestígio significativo de que essa padronização já afeta a política de EAD, nos anos 1980, é o enunciado concentrando os planos e a administração destas técnicas dispersos até 1982. Associando a este os fragmentos Sistema Nacional de Radiodifusão Educativa e recepção organizada, vamos perceber que tal política é estruturada uniformemente, desde 
a esfera macro do Sistema até a esfera micro da recepção. Além disso, na sdr 5, encontramos ao mesmo tempo traços de formalização e objetivação nos fragmentos política de estímulo e programas que reforçam a idéia de desenvolver a EAD a partir de estruturas capazes de manter a formalidade e objetividade necessárias a sua reprodução em larga escala.

Essa idéia, no entanto, já prevalece ao longo dos anos 1970. A sdr 6é atravessada por alusões não só aos processos de formalização e padronização - $\underline{\text { Projeto } L O G O S ~ I, ~ p r o j e t o, ~}$ assim como de objetivação: metodologia e técnica de ensino-aprendizagem para qualificação de professores, à distância. Contudo, além da objetivação se fazer presente mediante o enunciado utilização das tecnologias educacionais, evoca a sdr 7 uma profusão de fragmentos que demonstram que o sujeito do discurso encontra-se fortemente afetado pelas idéias da padronização e da formalização: projetos prioritários do Plano Setorial de Educação e Cultura 1972/74; Projeto Nacional de Teleducação (No 36); Plano Setorial 1975/79; política de educação; novo Plano Setorial para 1975/79; Projeto $N^{\circ}$ 36; Projeto No 7; estruturas para e pluri-escolares; estrutura mais aberta e flexível. O que implica supor que este último enunciado dá conta muito mais de uma estratégia discursiva do que de uma estrutura potencialmente aberta ou flexível.

Nos anos 1960, a recorrência a essas três características do processo industrial apresenta-se mais evidente. A ênfase da sdr 8 recai sobre a formalização e padronização, representadas por intermédio dos seguintes fragmentos: programa; programa Apollo; estruturação de um programa; Projeto SACI; iniciou um estudo e, em 1967, propôs medidas; relatório de 3 volumes descrevendo o Projeto SACI; Tal relatório resumia os estudos da CNAE; O presente relatório descreve 
a evolução desde maio de 1968 e esboça a seqüência de passos. De alguma forma, retoma aquela seqüência alusões feitas pela sdr 9 que, ao se referir a o plano educacional deve proporcionar um programa devidamente equilibrado e melhor organização e mais homogeneidade no sistema de educação, reforça a idéia de uma política de EAD estruturada de forma programática e homogênea.

Através do enunciado categórico a instrução gravada, bem preparada, pode ensinar ampla gama de matérias tão eficientemente quanto um professor, a sdr 8 também retoma a ênfase sobre a objetivação que, particularmente, marca a sdr 9: novos meios tecnológicos para fins educacionais; Programas de TVE pelos professôres mais talentosos e mais preparados, suplementariam a apresentação da matéria essencial dada pelos professôres de classe; a instrução por TV tem se mostrado da maior eficiência; treinamento de professôres ou instrutores; uso de guias, de observação do ensino por parte dos selecionados professôres de televisão; melhorar os métodos de instrução. Quando adicionamos a esses fragmentos o enunciado A eficiência de ensino deve ser aperfeiçoada por quaisquer meios possíveis, entendemos por que o sujeito do discurso não faz qualquer referência ao fato de que essa melhoria se dá em detrimento da perda de subjetividade no processo de ensino-aprendizagem.

Esses traços de objetivação, todavia, são remanescentes dos anos 1950. Analisando a sdr 10, observamos uma gama de fragmentos e enunciados que reiteram a idéia de tornar o processo de ensino-aprendizagem, cada vez mais, racional e objetivo: poderoso e eficiente meio; não podem estar presentes aos cursos tradicionais; faltam recursos educacionais adequados; pobreza de meios; por um motivo ou outro, não podem ir à escola; importantíssimo e eficaz instrumento, que não pode ser abandonado e que cumpre, muito pelo contrário, estimular e desenvolver. 
Os verbos estimular e desenvolver produzem como efeito de sentido, inclusive, a idéia de formalização de uma ação, voltada para equacionar tais necessidades ou demandas educacionais. Por seu turno, o fragmento a seguir indica a presença de vestígios de padronização: Graças a êle, em numerosas regiões do globo, como sejam, entre outras, os Estados Unidos e a Rússia, a Inglaterra e a Commonwealth, a França e a Alemanha, os Países Escandinavos e o Japão, milhões e milhões de pessoas, anualmente, iniciam e prosseguem estudos. Os nomes próprios aí mencionados reportam-se, justamente, a países cujos sistemas são considerados referência em relação aquilo que os alemães chamam de "escola à distância" (Fernschule), padrão que o Brasil vai alcançar, segundo a sdr 1 , cinco décadas depois.

Paralelamente à padronização, formalização e objetivação, outra característica da industrialização do ensino incide sobre o corpus discursivo - os métodos de controle científicos. Já durante os anos 1950, traços de sua ocorrência marcam a sdr 10: em numerosas regiões do globo; milhões e milhões de pessoas; não podem estar presentes aos cursos tradicionais; freqüentar escolas ou centros de treinamento; por um motivo ou outro, não podem ir à escola; reduzida densidade demográfica; escassez de tempo; faltam recursos educacionais adequados; pobreza de meios. Ao se referir a dados estatísticos e indicadores sócio-econômicos evoca o sujeito do discurso a idéia de conferir a este maior credibilidade, sobretudo, a partir de critérios e procedimentos de natureza científica.

A recorrência aos métodos científicos é mais incisiva, ainda, durante os anos 1960. Na sdr 9, observamos um sujeito do discurso fazendo questão de se reportar a uma série de indicadores que reforçam seus argumentos: desistentes; impacto total; Beneficios indiretos; Capacidade de 
ensino; eficiência de ensino; Melhoria da qualidade de instrução; a instrução por TV tem se mostrado da maior eficiência. Este último enunciado é reatualizado logo depois, em meio à sdr 8 , através da paráfrase $a$ instrução gravada, bem preparada, pode ensinar ampla gama de matérias tão eficientemente quan to um professor, pressupondo se tratar de uma inferência ou conclusão derivada de algum trabalho de pesquisa.

Além de mencionar outros indicadores (elevada confiabilidade, capabilidade de distribuir, Outra decorrência) e estatísticas (multi-bilhões de dólares de esfôrço espacial, Mais de um milhar de comparações), a sdr 8 faz referências diretas aos métodos de controle científicos. Enquanto na sdr 9 encontramos os enunciados observação do ensino por parte dos selecionados professores de televisão e melhorar os métodos de instrução, na sdr 8 chama-nos a atenção uma abundância de fragmentos nesse sentido, tais como: métodos de organização e de gerência; de pesquisa pura e aplicada e de inovação no desenvolvimento econômico e social; Tal relatório resumia os estudos da CNAE, durante dois anos, para avaliar as aplicações da tecnologia espacial à educação e às comunicações no contexto brasileiro.

Examinando os textos referentes aos anos 1970, a impressão que se tem é que o corpus discursivo, cada vez mais, apresenta vestígios daqueles métodos. A sdr 7 é marcada não só por alusões a indicadores do tipo fatores determinantes, maior eficácia operativa e oportunidades de formação segundo suas capacidades, como notadamente pelo seguinte fragmento: Com o novo Plano Setorial para 1975/79, extingue-se o Projeto $N^{o} 36$, substituído pelo Projeto $N^{o} 7$ que objetiva o Desenvolvimento de Novos Processos e Metodologias Educacionais. Considerando que, assim como Metodologias, Processos também remetem a procedimentos, o que depreendemos daí é que o Projeto $N^{0} 7$ submete, por excelência, 
o Projeto $N^{0} 36$ (Projeto Nacional de Teleducação) a métodos de controle científicos.

Maiores evidências, contudo, vamos encontrar em meio à sdr 6, começando pelas recorrentes alusões a dados e indicadores: nível de escolarização da clientela; Desde 1972 o DSU/MEC diagnosticou cerca de 150 a 200 mil professores leigos; alto indice de professores leigos; dificuldades de comunicação, acesso e infra-estrutura; eficiência. Essa ênfase torna-se mais acentuada, ainda, à medida que o sujeito do discurso faz referência a procedimentos metodológicos, inclusive, de cunho experimental: critério de escolha; Selecionadas as áreas para atuação; experimento da metodologia e técnica; testando, através do Projeto LOGOS I, metodologia e técnica de ensino-aprendizagem. Como se o referido projeto pudesse ser comparado a um laboratório de pesquisa em qualificação de professores, à distância.

Dois enunciados da sdr 5 indicam que essa concepção se mantém, também, nos anos 1980: As estações de televisão educativa atingem, atualmente, 300 municípios em todo o País, com audiência estimada de 32 milhões de pessoas e Todo esse trabalho vem sendo articulado com as secretarias estaduais e municipais de educação, para fins de recepção organizada. Associando o primeiro a outros fragmentos (significativos resultados; A consolidação, o aperfeiçoamento e a expansão; o fortalecimento e o aperfeiçoamento), percebemos como o sujeito do discurso continua a dar ênfase a indicadores e dados estatísticos. Correlacionando agora o primeiro ao segundo enunciado, vamos notar que recepção organizada alude ao monitoramento senão da audiência potencial de 32 milhões de pessoas, pelo menos, dos estudantes e professores da rede estadual e municipal de ensino, impossível de ser efetivado sem o concurso de métodos de controle científicos. 
Os indicadores e as estatísticas afetam significativamente o discurso em torno da política de EAD, durante os anos 1990. A referência aos primeiros é exemplar em se tratando da sdr 4: As dimensões continentais do Brasil, as enormes demandas em termos de capacitação da força de trabatho nacional, em especial dos professores da educação básica e o potencial das novas tecnologias; Considerando esses indicadores. Paralelamente às alusões a estes, tais como sucesso, $o$ fracasso e o desperdício, aceitação plena e imediata, as estatísticas pontuam a sdr 3: atinge 50 mil escolas; $100 \%$ de audiência e 100\% de utilização.

Marca as duas seqüências, muito mais ainda, a reiteração de alguns termos e expressões do mundo acadêmico-científico que evocam, quase que automaticamente, aqueles métodos de controle. Enquanto, na sdr 4, encontramos fragmentos que referem $o$ desenvolvimento de estudos e pesquisas na área de teleducação, o desenvolvimento de projetos de teleducação-telemática e o intercâmbio do conhecimento acadêmico na área nacional e internacional, na sdr 3 observamos os enunciados programa de treinamento de professores e operação experimental da TV Escola que retomam uma idéia cara à sdr 6, concebendo os projetos em EAD nos moldes de um laboratório de pesquisa. $\mathrm{O}$ sujeito do discurso, por sinal, destina todo um segmento da sdr 3 para acentuar o fato de a TV Escola encontrar-se submetida ao monitoramento científico, enfatizando: Quero chamar a atenção para o fato de que, além de termos lançado esse programa, tivemos a coragem de submetê-lo à avaliação independente externa: a Universidade Estadual de Campinas, através do Núcleo de Estudos de Políticas Públicas - Nepp.

Três enunciados da sdr 2 voltam a relacionar a TV Escola à pesquisa experimental, nos anos 2000: O projeto foi inspirado em duas experiências; "Projeto Ipê" transmitido 
pela TV Cultura; programa de atualização dos professores ingleses realizado pela BBC. Quando acrescentamos a isso a referência por parte da sdr 1 ao forte incentivo à pesquisa para o setor constituir uma das ações que conferem caráter estratégico à SEED, depreendemos que o discurso em torno da política de EAD é decisivamente afetado pela recorrência aos métodos de controle científicos, aos quais estão vinculadas outras características importantes à industrialização do ensino - trabalho preparatório, planejamento e organização, cujos vestígios no corpus discursivo podem ser examinados conjuntamente.

Tais características são evocadas, inclusive, quando a sdr 2 reporta-se àquelas duas experiências que inspiram a TV Escola. Ao referir que o "Projeto Ipê" foi desenvolvido pela Secretaria de Educação de São Paulo de 1984 a 1986, quando o atual ministro ocupou a pasta estadual e que o programa de atualização dos professores ingleses teria sido apresentado aos dirigentes do Ministério em visita à Inglaterra em 1995, o sujeito do discurso faz alusão não só ao trabalho preparatório (experiência desenvolvida de 1984 a 1986), como também ao planejamento (visita à Inglaterra em 1995) e à organização da política de EAD (pasta estadual, dirigentes do Ministério). Mas outros vestígios dessas características marcam, incisivamente, a sdr 2: estrutura de governo, Ministério da Educação, SEED, escola pública, ensino básico (que remetem à organização); importantes ações, política, projeto, programas, objetivos, programação de alta qualidade (que aludem ao planejamento); e A Secretaria de Educação a Distância, em sintonia com estados e municípios, vem, desde então, realizando investimentos significativos em uma infra-estrutura tecnológica que concerne, ao mesmo tempo, à organização, planejamento e trabalho preparatório. 
Nos anos 1990, observamos indícios do trabalho preparatório, sobretudo, na sdr 3: operação experimental da TV Escola; primeiro ano; dois anos de funcionamento da TV Escola; dois anos e meio. Enquanto na mesma sequência as referências ao Ministério da Educação e 50 mil escolas lembram-nos o princípio da organização, as alusões a esta na sdr 4 vão desde SENEB e rede de escolas até a articulação dos órgãos governamentais e não-governamentais. O planejamento, porém, é a característica que mais afeta o sujeito do discurso, nesse período. Seja através dos seguintes fragmentos da sdr 3: programas; lançamos; lançarmos a idéia de criar esse programa; lançado esse programa; programa de treinamento de professores; investimento que realizamos; beneficios que esperávamos alcançar e que alcançamos. Seja mediante uma série de ocorrências da sdr 4, tais como: Programa Nacional da Educação à Distância; Projeto Professor Alfabetizador, Projeto Complementação Pedagógica Projeto Alfabetizar é Construir, Projeto Sistema de Apoio Tecnológico à Educação e demais programas educativos.

O sujeito do discurso da sdr 5, também, não deixa de ser afetado pelo princípio do planejamento, como demonstram os seguintes vestígios: política de estímulo; programas; desenvolvimento de ações; criação; A consolidação, o aperfeiçoamento e a expansão; significativos resultados. Além de sugerir um sujeito influenciado pelo trabalho preparatório, os fragmentos que transcrevemos a seguir revelam um discurso que nos anos 1980 confere maior ênfase, todavia, ao processo de organização da política de EAD: A Fundação Centro Brasileiro de Televisão Educativa, criada pela Lei $n^{0} 5.198 / 67$, tem coordenado as atividades no âmbito das tecnologias educacionais, concentrando os planos e a administração destas técnicas; A criação do Sistema Nacional de Radiodifusão Educativa, integrado hoje por 14 emissoras de 
televisão, 340 repetidoras de televisão e 22 emissoras de rádio educativas, contribuiu decisivamente para o fortalecimento e o aperfeiçoamento da teleducação brasileira.

Organização e trabalho preparatório são duas características que, também, incidem conjuntamente em meio à sdr 6: Desde 1972 o DSU/MEC diagnosticou cerca de 150 a 200 mil professores leigos; O Departamento resolveu então partir para uma ação supletiva na tentativa de resolução do problema, testando, através do Projeto LOGOS I, metodologia e técnica de ensino-aprendizagem para qualificação de professores, à distância, sem retirá-los da sala de aula, num processo de 12 meses, a nível de $1^{0}$ grau. Atravessando a seqüência, encontramos ainda enunciados como programa específico em desenvolvimento, projeto, principal objetivo e eficiência que referem pistas da ocorrência do planejamento.

Refletindo, muito mais, a incidência da planificação de modo geral junto ao Regime Militar, nos anos 1970, a sdr 7 apresenta a um só tempo traços daquelas três características. Mantendo forte interdependência entre elas, o sujeito do discurso reporta-se aos princípios da organização, planejamento e trabalho preparatório, muitas vezes, de forma justaposta ou sobreposta, como ilustram exemplarmente os seguintes fragmentos: Foram estes os motivos que levaram o MEC a incluir, entre os projetos prioritários do Plano Setorial de Educação e Cultura 1972/74, o Projeto Nacional de Teleducação ( $\left.N^{o} 36\right)$, com o objetivo de coordenar, integrar e sistematizar a utilização das tecnologias educacionais; Com o novo Plano Setorial para 1975/79, extingue-se o Projeto $N^{o} 36$, substituído pelo Projeto $N^{o} 7$ que objetiva o Desenvolvimento de Novos Processos e Metodologias Educacionais, que hão de fazer da escola do futuro uma estrutura mais aberta e flexível.

Nos anos 1960, já observamos pistas dessa ocorrência e interdependência entre as três características. Enquanto 
o planejamento afeta a sdr 8 mediante enunciados, tais como, programa, esforços espaciais tipo programa Apollo, sub-produto dos multi-bilhões de dólares de esfôrço espacial, insumos úteis, custo baixo e com elevada confiabilidade, capabilidade de distribuir, a baixo custo; encontramos indícios do princípio da organização nos seguintes fragmentos: métodos de organização e de gerência; estruturação de um programa; Em 1966 a Comissão Nacional de Atividades Espaciais (CNAE) iniciou um estudo e, em 1967, propôs medidas a serem tomadas pelo Conselho Nacional de Pesquisas visando a uma solução para o problema educacional do país.

Correlacionando este último fragmento a outros que ainda perpassam a sdr 8, constatamos também a presença do trabalho preparatório: quatro elementos que, em conjunto, fornecem a base; relatório de 3 volumes descrevendo o Projeto SACI; Tal relatório resumia os estudos da CNAE, durante dois anos, para avaliar as aplicações da tecnologia espacial à educação $e$ às comunicações no contexto brasileiro. Além disso, reflete o discurso a incidência conjunta do trabalho preparatório e do planejamento: O presente relatório descreve a evolução desde maio de 1968 e esboça a seqüência de passos, entre as alternativas mais promissoras que poderão tornar o Brasil capaz de usufruir as vantagens de oportunidade universal de educação, no futuro próximo, a um custo razoável.

A organização e o trabalho preparatório não deixam de ser evocados na sdr 9. Enquanto o argumento melhor organização e mais homogeneidade no sistema de educação com maior participação da comunidade reporta-se à primeira característica, enunciados como treinamento de professôres ou instrutores, treinamento em serviço via TVE e professôres parcialmente treinados, embora se refiram a ações ainda a serem desenvolvidas, remetem à segunda característica. Mesmo assim, são os indícios da presença do planejamento 
que ganham relevo junto àquela seqüência: o plano educacional deve proporcionar um programa devidamente equilibrado; Programas de TVE; rápido desenvolvimento; Capacidade de ensino; impacto total; Benefícios indiretos.

Os indícios do planejamento afetam o sujeito do discurso desde os anos 1950. Na sdr 10, observamos sua presença em enunciados que vão da escassez de tempo, faltam recursos educacionais adequados, pobreza de meios e reduzida densidade demográfica até por um motivo ou outro, não podem ir à escola. Além disso, encontramos vestígios do planejamento concomitantemente a traços do princípio da organização em fragmentos como aplicados conjugadamente; poderoso e eficiente meio; importantíssimo e eficaz instrumento, que não pode ser abandonado e que cumpre, muito pelo contrário, estimular e desenvolver. Contudo, a ênfase do sujeito do discurso sobre um trabalho preparatório desenvolvido há longo tempo e em outros países parece ainda mais expressiva: $O$ ensino por correspondência, que surgiu há um século, vem sendo amplamente utilizado; É, aliás, sobretudo como instrumento de educação e treinamento de adultos que o ensino por correspondência tem sido encarado na maioria dos países em que vem florescendo; a sua utilização também, por incrivel que possa parecer à primeira vista, em instrução do nível de jardim da infância.

Vários fragmentos acima referidos chamam-nos a atenção para a forte incidência de outra característica da industrialização do ensino sobre o discurso em torno da política de EAD - a mecanização. Num primeiro momento, sua ocorrência na sdr 10 se dá de forma indireta, através de enunciados como pobreza de meios, poderoso e eficiente meio de educação e treinamento, importantíssimo e eficaz instrumento e recursos educacionais adequados. Num segundo momento, sua emergência ocorre de forma 
direta, mediante referências tais como ensino por correspondência; é que a escola vai, sob a forma de ensino por correspondência; ensino pelo rádio e pela televisão; o que os alemães chamam de "escola à distância" (Fernschule).

A recorrência à mecanização prevalece nos anos 1960. A maioria das referências da sdr 9, nesse sentido, diz respeito diretamente à tecnologia educacional, incluindo desde novos meios tecnológicos para fins educacionais, satélite e televisão educativa por satélites até Programas de TVE, instrução por TV e uso de TV. Ainda assim, seja direta seja indiretamente, a sdr 8 é ainda mais afetada pelo princípio da mecanização: adiantamento da tecnologia eletrônica; Satélite geoestacionário (síncrono); tecnologias avançadas; Projeto SACI (Satélite Avançado de Comunicações Interdisciplinares, isto é, educação e comunicações); aplicações da tecnologia espacial à educação e às comunicações; instrução pelo rádio e televisão.

Nos anos 1970, embora não seja tão enfático quanto na década anterior, o sujeito do discurso volta a se reportar à mecanização. Através da sdr 7 , alude ele ao Projeto Nacional de Teleducação, à utilização das tecnologias educacionais e ao recurso de estruturas para e pluri-escolares e com diferentes tipos de inovação, proporcionados pelas tecnologias educacionais. Mediante a sdr 6, além de se referir às dificuldades de comunicação, acesso e infra-estrutura, faz questão de acentuar aquele sujeito a metodologia e técnica de ensino-aprendizagem para qualificação de professores, à distância. Conforme vimos anteriormente, este enunciado vai ser retomado e reatualizado, mais adiante, de forma incisiva pelo T1.

A consolidação, o aperfeiçoamento e a expansão da televisão e do rádio educativos não deixam dúvida sobre a prevalência da mecanização, também, durante os anos 1980. Além disso, outros fragmentos referenciam a sua forte presença 
em meio a sdr 5: uso de novas tecnologias na área da educação; tecnologias educacionais; Sistema Nacional de Radiodifusão Educativa; 14 emissoras de televisão, 340 repetidoras de televisão e 22 emissoras de rádio educativas; estações de televisão educativa; teleducação brasileira. Mesmo de forma indireta, os termos técnicas, programas e audiência constituem ainda marcas do princípio da mecanização junto àquela sequência.

Esses vestígios da mecanização voltam a se fazer presentes ao longo dos anos 1990. Enquanto na sdr 4, encontramos enunciados como veiculação de mensagens (flashes) e programas, programas educativos e rede de escolas equipadas, a sdr 3 é atravessada por termos e expressões como transmissões, equipamentos, canal de satélites brasileiro e meios de comunicação. Além de fazer referência à tecnologia em geral - progresso técnico, novas tecnologias, recursos tecnológicos disponíveis, a sdr 4 atribui importância sobretudo à tecnologia educacional: educação à distância; Projeto Sistema de Apoio Tecnológico à Educação; TVE-RJ Rede Brasil e outras emissoras de rádio e televisão; reequipamento das TVEs; área de teleducação; teleducação-telemática.

Em se tratando da sdr 3, essa importância é atribuída à $T V$ Escola que parece sintetizar, nesse período, toda uma ênfase do sujeito do discurso sobre a tecnologia. Na sdr 2, a TV Escola volta a se destacar em meio a outros fragmentos que apontam para a recorrência ao princípio da mecanização. Se, por um lado, observamos referências como BBC e "Projeto Ipê" transmitido pela TV Cultura, por outro, vamos encontrar enunciados como novas ferramentas, novos instrumentos e novas tecnologias, infra-estrutura tecnológica, exclusão tecnológica e educação a distância. Este último, por sinal, ganha relevância crescente nos anos 2000, sendo referido por cinco vezes na sdr 1 , ao lado de 
outras recorrências, tais como, utilização intensiva das tecnologias de informação e comunicação; inovações tecnológicas e metodológicas; tecnologias educacionais; TV Escola e Proinfo; Sistema Universidade Aberta do Brasil.

A influência da mecanização sobre o discurso em torno da política de EAD pressupõe a incidência, concomitantemente, de outras características fundamentais à industrialização do ensino - divisão de trabalho, linhas de montagem, mudança de função/especialização. Sintomático nesse sentido é o fato de, igualmente à sdr 1, a Secretaria de Educação a Distância ocupar lugar de destaque na sdr 2, como estrutura de governo, vinculada ao Ministério da Educação, especialmente dedicada ao tema da EAD, o que implica especialização por excelência. Ainda relacionados a esta, encontramos os enunciados aperfeiçoamento e capacitação de professores do ensino básico e programa de atualização dos professores, cujo papel na divisão de trabalho aí evocada demonstra ser secundário e diferente, portanto, daquele reservado aos dirigentes do Ministério. Do mesmo modo, são secundários os lugares assumidos pelos estados e municípios, pasta estadual, Secretaria de Educação de São Paulo, escola pública e sala de aula que, no entanto, formam com a SEED uma linha de montagem em torno de programas de EAD.

Essa cadeia produtiva apresenta-se mais extensiva, ainda, durante os anos 1990. Se, na sdr 3, observamos seus indícios através de referências como meios de comunicação, escolas e professores, na sdr 4, encontramos uma diversidade de alusões à linha de montagem que envolve a política de EAD, destacando-se as seguintes: órgãos governamentais e não-governamentais; Unidades Federadas; Fundação Roquette Pinto/TVE-RJ Rede Brasil; escolas equipadas; clientela do ensino fundamental: alunos, professores e gestores. Refletem 
ambas as cadeias uma divisão de trabalho que seria comandada, respectivamente, pelo Ministério da Educação e $S E N E B$ e que implicaria um processo de especialização representado, no caso da sdr 3, mediante referências como Universidade Estadual de Campinas, através do Núcleo de Estudos de Políticas Públicas - Nepp e, no caso da sdr 4, por intermédio de fragmentos como Projeto Professor Alfabetizador, Projeto Complementação Pedagógica, Projeto Alfabetizar é Construir, Projeto Sistema de Apoio Tecnológico à Educação.

Os enunciados programas para formação e reciclagem de professores, secretarias estaduais e municipais de educação e recepção organizada, que pressupõem gestores, professores e tutores especialistas em EAD, são exemplares no sentido de percebermos vestígios do princípio da especialização nos anos 1980. Além da referência à Fundação Centro Brasileiro de Televisão Educativa, o fragmento Sistema Nacional de Radiodifusão Educativa, integrado hoje por 14 emissoras de televisão, 340 repetidoras de televisão e 22 emissoras de rádio educativas é mais significativo ainda de que a ênfase da sdr 5 reside na divisão de trabalho e nas linhas de montagem. Traços dessas características são encontrados, ademais, em estações de televisão educativa, 300 municípios em todo o País, 32 milhões de pessoas, pré-escolar, Supletivo de $1^{\circ}$ e $2^{\circ}$ graus.

Apesar de evocar o princípio da especialização, através de enunciados como cerca de 150 a 200 mil professores leigos e formação segundo suas capacidades presentes, respectivamente, na sdr 6 e sdr 7, a ênfase do sujeito do discurso nos anos 1970 se volta, também, para a divisão de trabalho e as linhas de montagem. Na sdr 6, a recorrência a essas características vai desde a importância atribuída primariamente à $D S U / M E C$ e secundariamente a estados 
da Paraíba e Piauí e territórios federais de Roraima, Rondônia e Amapá, até termos e expressões como unidades, quatro primeiras séries do ensino de $1^{\circ}$ grau e clientela. Além dos fragmentos Plano Setorial de Educação e Cultura 1972/74, Plano Setorial 1975/79 e Projeto Nacional de Teleducação, encontramos a ocorrência de ambas as características na sdr 7 no destaque dado ao Ministério da Educação e Cultura e nas referências à política de educação, sistema educativo, estruturas para e pluri-escolares.

Conselho Nacional de Pesquisas, Comissão Nacional de Atividades Espaciais (CNAE) e Projeto SACI constituem enunciados da sdr 8 que não se reportam apenas à divisão de trabalho, como também ao princípio da especialização. Bastante associados aos mesmos, observamos ainda indícios que remetem às linhas de montagem - instrução pelo rádio e televisão, escolas de todo o Brasil, sala de aula, professor. Na sdr 9, todavia, este último aparece em meio a uma série de alusões à especialização: professôres ou instrutores, professôres mais talentosos e mais preparados, selecionados professôres de televisão, professôres parcialmente treinados. Já os vestígios da divisão de trabalho e da linha de montagem podem ser encontrados junto aos seguintes fragmentos: sistema de educação; televisão educativa; áreas rurais; professôres; estudantes; alfabetização de adultos; sala de aula.

Examinando a sdr 10, vamos notar que as alusões à divisão de trabalho já se apresentam bastante correlacionadas à evocação às linhas de montagem. São vários os indícios da ocorrência simultânea dessas características, nos anos 1950: pelo rádio e pela televisão; jardim da infância; escolas; residentes da zona rural ou de pequenas localidades; diversos outros grupos (donas de casa, incorporados às forças armadas para a prestação do serviço militar, presidiários e reclusos, de modo geral). São significativos, também, os 
enunciados que invocam o princípio da especialização centros de treinamento; aperfeiçoamento profissional; empregados de todos os tipos e categorias (funcionários, comerciários, bancários, industriarios, etc), antecipando a ênfase, retomada nos anos 2000, relativamente ao aperfeiçoamento $e$ capacitação e à formação continuada ao longo da vida.

Os anos 1950 antecipam, muito mais ainda, uma característica da industrialização do ensino que marca, profundamente, todo o discurso em torno da política de EAD - a racionalização. Seus vestígios podem ser encontrados na sdr 10, de modo especial, em enunciados que fazem alusão à eficiência e à eficácia da educação a distância: amplamente utilizado, em nossos dias, como poderoso e eficiente meio de educação e treinamento; importantíssimo e eficaz instrumento, que não pode ser abandonado e que cumpre, muito pelo contrário, estimular e desenvolver. A recorrência à racionalização, entretanto, atravessa praticamente toda a sdr 10, mediante uma série de fragmentos que enaltecem os impactos sócio-culturais da EAD, destacando-se os seguintes: milhões e milhões de pessoas, anualmente, iniciam e prosseguem estudos, que, por outra forma, thes teriam sido muito penosos ou impossiveis de fazer; de residentes da zona rural ou de pequenas localidades, a que faltam recursos educacionais adequados, em virtude da pobreza de meios e da reduzida densidade demográfica, inerentes à situação.

Os indícios da racionalização continuam substancialmente presentes nos anos 1960, logo se sobressaindo as alusões que apontam para os impactos da EAD sobre as nações. Na sdr 9, são exemplares nesse sentido os seguintes fragmentos: A fim de produzir um impacto total em uma nação, o plano educacional deve proporcionar um programa devidamente equilibrado capaz de convencer a todos os indivíduos a dar sua máxima contribuição à sociedade; a televisão 
educativa por satélites é o avanço mais arrojado de que se dispõe para ajudar a impelir as nações em desenvolvimento para a era da educação e da alfabetização universais. A sdr 8, também, é marcada por uma alusão expressiva nessa direção: quatro elementos que, em conjunto, fornecem a base para um programa que poderia, ràpidamente, colocar o Brasil entre as nações líderes nos campos de oportunidade educacional, de pesquisa pura e aplicada e de inovação no desenvolvimento econômico e social.

As referências aos princípios da inovação e da eficiência, por sinal, ajudam a evocar a racionalização. Enquanto na sdr 9 as encontramos nos enunciados A eficiência de ensino deve ser aperfeiçoada por quaisquer meios possíveis, a instrução por TV tem se mostrado da maior eficiência e proporcionar inovações na estrutura social, na sdr 8 as observamos em Mais de um milhar de comparações de instrução convencional de sala de aula com a instrução pelo rádio e televisão, não deixam dúvidas de que a instrução gravada, bem preparada, pode ensinar ampla gama de matérias tão eficientemente quanto um professor.

A relação custo-benefício é outro princípio racional evocado, nesse período. Seja através da sdr 9: Benefícios indiretos. A TVE pode proporcionar melhor organização e mais homogeneidade no sistema de educação com maior participação da comunidade no referido sistema. Seja, muito mais ainda, por intermédio da sdr 8: Como sub-produto dos multi-bilhões de dólares de esfôrço espacial, o adiantamento da tecnologia eletrônica pode colocar, por custo baixo e com elevada confiabilidade, auxílios eletrônicos a educação que podem vir a ser usados nas escolas de todo o Brasil; alternativas mais promissoras que poderão tornar o Brasil capaz de usufruir as vantagens de oportunidade universal de educação, no futuro próximo, a um custo razoável. 
Em meio à sdr 9, destacam-se ainda uma série de vestígios alusivos ao princípio da eficácia: Melhoria da qualidade de instrução. Programas de TVE pelos professôres mais talentosos e mais preparados, suplementariam a apresentação da matéria essencial dada pelos professôres de classe; Capacidade de ensino. O uso de TV com professôres parcialmente treinados aumentará grandemente o número de estudantes a receberem boa educação, especialmente em áreas rurais. Representando como que uma síntese da prevalência dos princípios da inovação, eficiência, eficácia e custo-benefício, encontramos na sdr 8 o seguinte fragmento: Outra decorrência dos esforços espaciais tipo programa Apollo são os métodos de organização e de gerência que podem fornecer insumos úteis para a estruturação de um programa brasileiro destinado a aplicar tecnologias avançadas para proporcionar universal oportunidade de educação no Brasil inteiro.

Sinônimos da racionalização, esses princípios voltam a afetar o discurso em torno da política de EAD nos anos 1970. Além de enunciados como coordenar, integrar e sistematizar a utilização das tecnologias educacionais, com vistas à universalização do ensino aludirem a uma ação racional, os princípios da inovação e da eficácia acometem a sdr 7 através de dois fragmentos: Com o novo Plano Setorial para 1975/79, extingue-se o Projeto $N^{0} 36$, substituído pelo Projeto $N^{o} 7$ que objetiva o Desenvolvimento de Novos Processos e Metodologias Educacionais, que hão de fazer da escola do futuro uma estrutura mais aberta e flexivel, oferecendo a todos oportunidades de formação segundo suas capacidades; será necessário conferir à educação maior eficácia operativa, com o recurso de estruturas para e pluri-escolares e com diferentes tipos de inovação, proporcionados pelas tecnologias educacionais.

Ênfase por parte da sdr 7 tende a receber, também, o princípio da eficiência, cujos vestígios encontram-se 
bastante atrelados ao discurso em torno do desenvolvimento nacional (retomado, nos anos 2000, por intermédio do T1): engajar e articular a educação ao processo de desenvolvimento do País, de modo intrínseco, não deixando que ela permaneça apenas a reboque desse desenvolvimento; o MEC situa a educação como integrada ao desenvolvimento, como um dos seus fatores determinantes e por ele condicionada, na consecução de suas finalidades essenciais; estreitar o liame entre a política de educação e o esforço de desenvolvimento e democratizar o sistema educativo, orientando-o no sentido de contribuir para a correção das injustiças e discriminações.

Marcas da eficiência se fazem presentes, também, em meio à sdr 6: O projeto restringiu-se à qualificação, embora a habilitação fosse ideal, tendo em vista o nível de escolarização da clientela, que presumivelmente não teria condições de atingir eficiência através de estudos a nível de $2^{\circ}$ grau, o que forçosamente interferiria no experimento da metodologia e técnica. Contudo, são os indícios da relação custo-benefício que se apresentam de forma ainda mais incisiva junto àquela seqüência: $O$ Departamento resolveu então partir para uma ação supletiva na tentativa de resolução do problema, testando, através do Projeto LOGOS I, metodologia e técnica de ensino-aprendizagem para qualificação de professores, à distância, sem retirá-los da sala de aula; O critério de escolha dessas unidades deveu-se ao alto indice de professores leigos existentes nesses locais e em face das dificuldades de comunicação, acesso e infra-estrutura, o que se prestava mais propriamente para o experimento, pelas dificuldades.

Dois fragmentos da sdr 5, por sua vez, completam-se para reiterar a alusão aos princípios da eficiência e da eficácia: A consolidação, o aperfeiçoamento e a expansão da televisão e do rádio educativos representam significativos resultados da política de estímulo ao uso de novas tecnologias na área da 
educação; e A criação do Sistema Nacional de Radiodifusão Educativa, integrado hoje por 14 emissoras de televisão, 340 repetidoras de televisão e 22 emissoras de rádio educativas, contribuiu decisivamente para o fortalecimento e o aperfeiçoamento da teleducação brasileira. Durante os anos 1980, entretanto, chamam-nos atenção a presença de traços que se reportam, quase que direta ou propriamente, à racionalização: tem coordenado as atividades no âmbito das tecnologias educacionais, concentrando os planos e a administração destas técnicas dispersos até 1982; Todo esse trabalho vem sendo articulado com as secretarias estaduais e municipais de educação, para fins de recepção organizada.

Essa recorrência à racionalidade destaca-se, igualmente, como um dos traços distintivos dos anos 1990. Encontramos seus vestígios, sobretudo, junto à sdr 4, através de enunciados como aceleração do progresso técnico, potencial das novas tecnologias, contribuição metodológica efetiva e busca do equilíbrio entre a educação presencial e a educação à distância. Uma síntese mais expressiva da incidência da racionalização sobre o sujeito do discurso é a seguinte série consecutiva de fragmentos: otimização dos recursos tecnológicos disponíveis; reequipamento das TVEs; ampliação da rede de escolas equipadas; desenvolvimento de estudos e pesquisas na área de teleducação; articulação dos órgãos governamentais e não-governamentais para o desenvolvimento de projetos de teleducação-telemática; intercâmbio do conhecimento acadêmico na área nacional e internacional.

Nesse período, o sujeito do discurso é ainda afetado, particularmente, pela relação custo-benefício, cujos indícios atravessam toda a sdr 3: o investimento que realizamos foi realmente pequeno se comparado aos beneficios que esperávamos alcançar e que alcançamos; contrapor a idéia de que o fato de não termos alcançado no primeiro ano $100 \%$ de audiência e 
100\% de utilização caracterizaria o fracasso e o desperdício de recursos; o que estávamos fazendo, paulatinamente, era ir treinando as pessoas e ir conquistando os professores para o uso da $T V$ Escola, o que haveria de render frutos importantes, como os que estamos colhendo agora. Além disso, marca aquela seqüência o sugestivo enunciado TV Escola, um caso de sucesso que, em parte, é retomado pela sdr 1, mediante a alusão sucesso alcançado pela SEED, evidenciando assim a prevalência do princípio da eficácia, nas últimas duas décadas.

Nos anos 2000, contudo, percebemos a ocorrência significativa de dois outros princípios. A sdr 2 é demarcada por um conjunto de fragmentos que evoca, de modo especial, a inovação e a eficiência, tais como: política que busca a democratização e melhoria da qualidade da educação pública brasileira, por meio da adoção de novos instrumentos e novas tecnologias, até então ainda embrionárias na escola pública do país; A Secretaria de Educação a Distância, em sintonia com estados e municípios, vem, desde então, realizando investimentos significativos em uma infra-estrutura tecnológica que, além de enriquecer o ensino presencial, serve de base para importantes ações de educação a distância..

O enunciado inovações tecnológicas e metodológicas para a melhoria da qualidade da educação no país constitui, por conseguinte, uma síntese de que os princípios da inovação e da eficiência atingem, decisivamente, a sdr 1. Com efeito, representa tal enunciado a evidência de que a recorrência sistemática e permanente por parte do sujeito do discurso à racionalização, ao longo das últimas seis décadas, funda e imprime, de modo quase inexorável, a incidência das características da produção industrial sobre o nosso corpus discursivo. Por sinal, não parece mera coincidência o fato de o T10, antecipando-se aos demais textos, intitular-se 
"A educação e o treinamento por correspondência: histórico e potencialidades".

Apesar de não fazer qualquer menção direta, nem mesmo em suas "Referências Bibliográficas", lembra o T10 a discussão de Max Weber sobre "A 'racionalização' da educação e treinamento", formulada ainda nos anos 1910, por ocasião de suas análises sobre a burocracia. Naquele momento, já acentuava Weber o fato de a qualificação profissional constituir uma condição fundamental à "burocracia moderna". Partindo da Alemanha, "seu berço principal", o treinamento constituía parte imprescindível da reforma do serviço público, desde a China até os Estados Unidos, acompanhando a crescente burocratização do capitalismo, "com sua exigência de técnicos, funcionários, preparados com especialização, etc." (WEBER, 1963b, p.278) Um tipo de "educação" que, pelas suas demandas, dominava e influenciava principalmente as instituições de ensino superior e médio nos países de Primeiro Mundo.

Elemento fundamental à constituição, organização e consolidação do Estado e das grandes empresas capitalistas modernas, "como instrumento de 'socialização' das relações de poder, a burocracia foi e é um instrumento de poder de primeira ordem - para quem controla o aparato burocrático." (WEBER, 1963b, p.264) Neste sentido, a burocracia assume características específicas que a tornam a "forma mais racional" e o "tipo mais puro" de exercício de dominação. Em princípio, rege áreas de jurisdição mediante leis ou normas administrativas e suas atividades regulares são consideradas deveres oficiais, exercidos sob o comando de autoridades e com base na tomada de decisões metódicas. Na esfera privada, esses elementos constituem a administração burocrática e, no serviço público, a autoridade burocrática. 
Caracteriza a burocracia o fato de o princípio de hierarquia implicar um sistema estável de subordinação, cuja supervisão se dá de forma verticalizada. A burocracia constitui um tipo de dominação legítima de caráter racional, assentada na legitimidade da ordem estabelecida, portanto, de forma impessoal, objetiva e legalmente estatuída. O que prevalece é a dominação legal, baseada na idéia de que o direito pode ser estabelecido de modo racional e respeitado por todos os membros de uma organização. Do mesmo modo que o senhor legal típico - o "superior", que pode ser inclusive um chefe de Estado, ao ordenar obedece à ordem impessoal que determina seu mando, os funcionários subordinados, "ao obedecerem ao senhor, não o fazem à pessoa deste mas, sim, àquelas ordens impessoais e que, por isso, só estão obrigados à obediência dentro da competência objetiva, racionalmente limitada, que lhe foi atribuída por essas ordens" (WEBER, 1994, p.142).

Refletindo o próprio fato de a atividade burocrática apresentar-se desvinculada da vida privada, nem a "autoridade institucional" nem seus subordinados apropriam-se do cargo e dos meios de administração e produção. A posse destes está segregada do quadro administrativo, pelo princípio da desvinculação entre o patrimônio da instituição e o patrimônio privado dos seus membros. Mediante o processo de concentração nas mãos dos chefes dos institutos de pesquisa, por exemplo, "a massa de pesquisadores e docentes é separada de seus 'meios de produção', da mesma forma que a empresa capitalista separou os trabalhadores dos seus." (WEBER, 1963b, p.260)

$\mathrm{O}$ direito ao cargo, por sua vez, reduz-se a assegurar o exercício da atividade puramente objetiva, determinada pelas normas referentes ao seu pleno desempenho. 
A investidura em um cargo na burocracia implica assumir uma "profissão", cuja fidelidade ou lealdade não tem finalidades de ordem pessoal, mas apenas e tão somente funcional. Por um lado, põe em prática a possibilidade ótima da especialização administrativa, levando em conta essencialmente critérios "objetivos". Por outro, o cumprimento objetivo das tarefas segue regras calculáveis, nos moldes dos princípios da calculabilidade de resultados que, própria à cultura moderna e à sua base técnico-econômica, é considerada "virtude especial" da atividade burocrática. Sua natureza específica, por sinal, "desenvolve-se mais perfeitamente na medida em que a burocracia é 'desumanizada', na medida em que consegue eliminar dos negócios oficiais o amor, o ódio, e todos os elementos pessoais, irracionais e emocionais que fogem ao cálculo." (WEBER, 1963b, p.251)

Não causa estranheza o fenômeno alcançar o Brasil, de modo especial, a partir da década de 1930, quando começam a ser lançadas as bases de um Estado de Bem Estar Social. Determinadas, em geral, por injunções econômicas, as ações vinculadas à "chamada "política de bem-estar social' operam principalmente no sentido da burocratização, pois essas tarefas são, em parte, atribuídas ao Estado pelos grupos de interesse e, em parte, o Estado as usurpa, devido a sua política de poder ou a motivos ideológicos." (WEBER, 1963b, p.248) Mesmo o Welfare State não representando um conceito tão em voga no Brasil, devido inclusive aos "baixos graus de eficácia e efetividade" das políticas sociais, Draibe (1989) considera que o "Estado social" emerge e se consolida no país, em particular, entre os anos 1930 e 1970. Configurando uma forma de regulação social no âmbito do Estado capitalista, o Welfare State manifesta-se através das transformações 
que incidem sobre a relação Estado, economia e sociedade e fazem emergir sistemas públicos ou estatais de habitação, saúde, educação, entre outros, que afetam o nível de vida da classe trabalhadora, substituindo de alguma forma as políticas de emprego e renda.

Criado, justamente, para consolidar a reforma administrativa deflagrada pelo governo Getúlio Vargas com vistas a "racionalizar o serviço público no país", o DASP nasce em 1938, subordinado à Presidência da República, o que lhe confere papel relevante junto à definição das políticas governamentais. Com o fim do Estado Novo em 1945, o Departamento é profundamente reestruturado. “A partir de então, suas funções assumiram um caráter de assessoria, exceto no tocante à seleção e aperfeiçoamento de pessoal, área em que se manteve como órgão executor." (FUNDAÇÃO, 1997) Transformado em Secretaria de Recursos Humanos do Ministério do Planejamento, Orçamento e Gestão, mesmo assumindo o papel de "modernizar e desburocratizar" a administração federal (BRASIL, 2008e), em 2006 o órgão continuava às voltas com a reestruturação da política de capacitação de pessoal (BRASIL, 2006h).

Essa política, em todo caso, não se resume àquela Secretaria nem ao Ministério do Planejamento, sendo resultado da iniciativa de outras instâncias do Governo Federal, a destacar o Ministério da Educação e a SEED. O Sistema Universidade Aberta do Brasil, além de estar a serviço da democratização da educação superior no país, na medida em que se encarrega da formação inicial e continuada de professores constitui, por conseguinte, uma nova estratégia de racionalização do desempenho dos trabalhadores da rede pública de ensino. Por extensão, atualiza e conduz a estágios avançados o processo de burocratização do 
Estado brasileiro que tende a seguir um movimento mais amplo ${ }^{19}$.

Resulta esse processo, normalmente, em uma forte tendência de subordinação do servidor público ao aparelho burocrático: "o burocrata profissional está preso à sua atividade por toda a sua existência material e ideal. Na grande maioria dos casos, ele é apenas uma engrenagem num mecanismo sempre em movimento, que lhe determina um caminho fixo." (WEBER, 1963b, p.265) Esse mecanismo, inclusive, é quem determina o caminho a ser seguido, ou mais precisamente, o que pode e o que não deve ser dito pelos burocratas responsáveis pela enunciação do discurso oficial, a começar pelos próprios chefes de Estado.

As posições assumidas pelos cinco presidentes que constituem o "discurso presidencial da República Militar Brasileira" nos ajudam a entender como, ao usar a palavra oficial, cada um deles não ocupa um lugar pessoal, mas historicamente afetado por uma FD que o condiciona a exercer a mesma função de sujeito. "O fato de haver uma mudança de locutor nas diferentes séries temporais não determina a concepção de cinco diferentes sujeitos de discurso. Dito de outra forma: esse discurso possui

19 "La administración pública burocrática pretendió erradicar los vicios del patrimonialismo y terminó fusionándose en una rigidez burocrática con diversas manifestaciones 'buropatológicas' en casi todos los países latinoamericanos. Al paradigma burocrático de la administración pública en Latinoamérica se incorporan las teorías organizacionales en los años setenta. Y en los ochenta emerge una gerencia pública que adopta métodos y técnicas de gestión de empresas privadas, con estrategias basadas en la delegación de funciones y en evaluaciones de desempeño, la cual está sustituyendo a la administración burocrática patrimonialista, sobre todo en la provisión de los servicios públicos." (HERNÁNDEZ, 2002, p.27) 
cinco locutores, mas apenas um sujeito do discurso." (INDURSKY, 1997, p.139) Parafraseando a autora, o discurso que ora analisamos possui $n$ locutores, mas apenas e tão somente um sujeito do discurso - o Estado.

Do ponto de vista discursivo, significa considerarmos que o nosso corpus reveste-se, no fundo, de práticas discursivas que transcendem o caráter de "modos de fabricação de discursos" e ganham consistência em instituições, conjuntos técnicos, padrões comportamentais etc., responsáveis pela sua imposição, manutenção e legitimação (FOUCAULT, 1997, p.12). Com efeito, independentemente do tempo, os discursos aí pronunciados acabam revelando não um sujeito lingüístico nem individual, mas um sujeito falante ${ }^{20}$ inscrito numa mesma topografia social ou lugar de enunciação. No caso, o Estado brasileiro, representado através de ministérios (a destacar o MEC), por sua vez, representados por intermédio de comissões, coordenações, departamentos, secretarias (incluindo a SEED), todos constitutivos de uma instância

20 De fato, esclarece Mazière (2007, p.22), o sujeito da AD só é possível ser apreendido "no interior de cada uma das buscas do analista", mesmo porque sua concepção varia substancialmente. "O marxismo, que é uma referência durante os primeiros anos da $\mathrm{AD}$, o sujeita. Foucault o dispersa na formação discursiva. A colaboração entre lingüistas e psicanalistas o resgata do psicologismo. A colaboração com os historiadores introduz um sujeito da história. O peso da interdiscursividade organiza 'a deslocalização tendencial do sujeito enunciador' na materialidade dos enunciados, segundo uma fórmula de Michel Pêcheux. As sofisticações da pragmática o reconfiguram em uma escala de ações e co-ações enunciativas e semânticas na qual ele pode se multiplicar e se diluir. Nos casos mais simples, o sujeito é, no mínimo, dois: falante empírico e enunciador lingüístico." 
que, lembrando Foucault (2004, p.7), tende a autorizar a cada qual falar em seu nome, desde que o discurso esteja inscrito na ordem institucional.

Mais precisamente, trata-se de entendermos que os sujeitos aí envolvidos enunciam através de uma parte do aparelho de Estado que realiza uma série de normas estabelecidas pelas injunções econômicas. "Esse estatuto, literalmente, dá corpo à profissão, e esse corpo investe o discurso que nele se articula - e portanto os indivíduos que o enunciam - de um poder." (LECOURT, 1971, p.60) O que precisamos compreender, esclarece Pêcheux (1968), referido por HENRY (1990, p.26), é que esses sujeitos assumem uma posição definida anteriormente no sistema de produção, que lhes é apagada e cabe a eles próprios reconhecer, mesmo sem ser obrigados formalmente

\section{A ordem e o sujeito do discurso oficial}

Na condição de "sempre-já" sujeito, assim como qualquer outro que assume uma posição condicionada institucionalmente, o sujeito que fala em nome do Estado - tomando emprestada deste a palavra oficial - acaba "sempre-já" esquecendo-se das determinações que o colocaram no lugar que ocupa (PÊCHEUX, 1988, p.170). Esse "esquecimento", porém, não diz respeito a um lapso de memória, mas àquilo que sempre se ignora, ainda que seja extremamente familiar às causas que determinam o discurso (PÊCHEUX; FUCHS, 1990, p.238). “Memória e esquecimento são, assim, indissociáveis na enunciação do político." (COURTINE, 1999, p.22) 
O esquecimento $n^{0} 1^{21}$, afinal de contas, caracteriza-se pela impossibilidade do locutor-sujeito ter acesso ao discurso do Outro, isto é, aos discursos-transversos e pré-construídos que condicionam o seu próprio discurso. $\mathrm{O}$ funcionamento do discurso-transverso, segundo Pêcheux (1988, p.171), tem a ver com a metonímia, correspondendo, a um só tempo, a "'como dissemos' (evocação intradiscursiva); 'como todo mundo sabe' (retorno do Universal no sujeito); 'como todo mundo pode ver' (universalidade implícita de toda situação 'humana')." Emprestado de Henry (1974), a noção de pré-construído por sua vez refere-se a uma construção anterior, exterior, independente e oposta ao que acaba sendo "construído" pelo enunciado, remetendo "aos conteúdos de pensamento do 'sujeito universal'".

Precisamos compreender contudo, esclarece Foucault (2002, p.69), que o pré-conceitual, "em lugar de delinear um horizonte que viria do fundo da história e se manteria através dela, é, pelo contrário, no nível mais 'superficial' (no nível dos discursos), o conjunto das regras que aí se encontram efetivamente aplicadas." Enquanto discurso-transverso, acrescenta Pêcheux (1988, p.167), a interdiscursividade mobiliza os elementos discursivos representados pelo interdiscurso como um pré-construído, através do qual o sujeito se reveste no sujeito falante.

21 É através do esquecimento $\mathrm{n}^{\circ} 2$, por outro lado, que todo sujeito-falante apóia ou encontra sua "liberdade", ao poder selecionar "no interior da formação discursiva que o domina, isto é, no sistema de enunciados, formas e seqüências que nela se encontram em relação de paráfrase - um enunciado, forma ou seqüência, e não um outro, que, no entanto, está no campo daquilo que poderia reformulá-lo na formação discursiva considerada." (PÊCHEUX, 1988, p.173) 
Muito embora, em princípio, constitua o "fio do discurso" do sujeito, o intradiscurso por seu turno acaba caracterizando o efeito do interdiscurso sobre ele próprio, sendo pois determinado por uma exterioridade.

Cabe à forma-sujeito, explica Althusser (1973), retomado por Pêcheux (1988, p.183), "reverter" essa determinação, uma vez que: "Todo indivíduo humano, isto é, social, só pode ser agente de uma prática se se revestir da forma de sujeito. A 'forma-sujeito', de fato, é a forma de existência histórica de qualquer indivíduo, agente das práticas sociais." Constituindo, então, a forma mediante a qual o "sujeito do discurso" assujeita-se a uma FD, a forma-sujeito realiza a incorporação e dissimulação dos elementos do interdiscurso no intradiscurso.

A unidade de um discurso, aliás, atravessa o tempo e transcende os textos e falas individuais, sem que isso suponha permanência mas, ao contrário, transformação dos discursos. Não são os objetos, seu domínio, seu ponto de emergência ou seu modo de caracterização que se mantêm constantes e sim a relação entre suas superfícies. A unidade do discurso reside, pois, não na coerência visível e horizontal dos elementos heterogêneos que a constituem, mas no sistema que possibilita e regulamenta sua formação, mediante os processos de justaposição, coexistência, interação e relacionamento estabelecidos entre esses elementos pela prática discursiva.

A FD, por essa razão, constitui um conjunto complexo de relações que funcionam como regras e caracterizam o discurso pela regularidade ou positividade de uma prática. Prescreve esse sistema de formação aquilo que deve ser correlacionado a essa prática, estabelecendo como a mesma deve se referir a determinado objeto, através de uma determinada enunciação, utilizando um determinado 
conceito e organizando uma determinada estratégia. Essa positividade do discurso exerce o papel, de certa forma, de um a priori histórico, o conjunto das regras que vão caracterizar toda uma prática discursiva e que não se resume ao encadeamento lógico de proposições nem a recorrência de determinados temas: "essa forma de positividade (e as condições de exercício da função enunciativa) define um campo em que, eventualmente, podem ser desenvolvidas identidades formais, continuidades temáticas, translações de conceitos, jogos polêmicos." (FOUCAULT, 2002, p.145-146)

Tratando também do problema da unidade, já esclarecia Althusser (1992, p.70-71) que a dispersão dos aparelhos ideológicos de Estado, em particular, tinha uma explicação. Instituindo-se, principalmente, através do ideológico, o que unifica a diversidade dos AIE “é este funcionamento mesmo, na medida em que a ideologia, na qual funcionam, está de fato sempre unificada, apesar da sua diversidade e contradições, sob a ideologia dominante, que é a ideologia da 'classe dominante'." No fundo, os inúmeros discursos encontram-se circunscritos a um processo mais amplo, através do qual a ideologia interpela os indivíduos em sujeitos, tornando-os, por isso mesmo, "sempre/já sujeitos" que se submetem a um outro sujeito, cuja condição é muito mais abrangente. Conforme explica Pêcheux (1988, p.163), o que essa tese afirma é que o "não sujeito" acaba sendo transformado em "sujeito" por parte da ideologia e, por extensão, em sujeito do discurso pela identificação com a FD que o assujeita.

$\mathrm{Na}$ acepção althusseriana, como toda ideologia pressupõe um centro, ocupado por um Sujeito único e absoluto que interpela, a sua imagem e semelhança, todos os 
indivíduos a sua volta ${ }^{22}$, acontece que o indivíduo é interpelado para livremente realizar sua própria submissão, constituindo-se em sujeitos, portanto, pela sua sujeição. Antes de qualquer coerção, aliás, a maioria dos sujeitos entrega-se à ideologia, às práticas determinadas pelos rituais dos AIE:

Todos os agentes da produção, da exploração e da repressão, sem falar dos "profissionais da ideologia" (Marx) devem de uma forma ou de outra estar "imbuídos" desta ideologia para desempenhar "conscienciosamente" suas tarefas, seja a de explorados (os operários), seja a de exploradores (capitalistas), seja a de auxiliares na exploração (os quadros), seja a de grandes sacerdotes da ideologia dominante (seus "funcionários") etc... (ALTHUSSER, 1992, p.58-59).

22 "Se acrescentarmos, de um lado, que esse sujeito, com um $S$ maiúsculo - sujeito absoluto e universal -, é precisamente o que J. Lacan designa como o Outro (Autre, com A maiúsculo), e, de outro lado, que, sempre de acordo com a formulação de Lacan, 'o inconsciente é o discurso do Outro', podemos discernir de que modo o recalque inconsciente e o assujeitamento ideológico estão materialmente ligados, sem estar confundidos, no interior do que se poderia designar como o processo do Significante na interpelação e na identificação, processo pelo qual se realiza o que chamamos as condições ideológicas da reprodução/transformação das relações de produção." (PÊCHEUX, 1988, p.133-134) 
A consciência individual, para retomar a expressão de Bakhtin (1988, p.36), não é o arquiteto da ideologia, "mas apenas um inquilino do edifício social dos signos ideológicos." Em suma, acentua Pêcheux (1988, p.171), todo sujeito (locutor, sujeito da enunciação, sujeito-falante que remete à articulação ou discurso-transverso) é assujeitado ou interpelado (é determinado a ser o que é, agir como age, falar como fala) pelo sujeito universal da ideologia (Sujeito, o Outro, que se refere ao pré-construído) enquanto singular insubstituível. Como uma faca de dois gumes, resume Maingueneau (1993, p.33), essa instância de subjetividade enunciativa (Sujeito) constitui, legitima e atribui autoridade ao sujeito enquanto sujeito de seu discurso; em contrapartida, o assujeita e o submete as suas regras.

Não tendo o controle sobre o modo como a língua e a história o convocam, resta ao sujeito discursivo funcionar seja através do inconsciente seja mediante o concurso da ideologia que lhe é, antes de tudo, constitutiva (ORLANDI, 2002, p.47). Compondo-se por uma forte articulação entre o inconsciente (relação com o dizer do outro) e o social (relação com a história), o sujeito tem afetado, por um lado, o seu funcionamento psíquico e, por outro, o seu funcionamento histórico-social (INDURSKY, 2000, p.71). Cabe aos sujeitos, concorda Foucault em entrevista a Rouanet e Merquior (1971, p.30), limitar-se a ingressar em um sistema, mantido há tempo, com sistematicidade e existência próprias, independente da existência e consciência de cada indivíduo.

Nesse sentido, tanto as práticas sociais quanto discursivas impõem-se ao sujeito que acaba agindo segundo determinações, mas perdendo a consciência desse processo. Ainda que a prática discursiva não se restrinja 
à atividade de um sujeito e sim a regras que o mesmo necessita obedecer ao participar do discurso (LECOURT, 1971, p.51), a análise dos enunciados e das formações discursivas prescinde de tomar como referência não apenas o sujeito individual, como também uma consciência coletiva, ou mesmo, uma subjetividade soberana ou transcendental. Ela deve se situar, ao contrário, no nível mesmo daquilo que é dito, mas que não é dito de qualquer lugar e sim considerado no jogo de uma exterioridade, em que o sujeito é situado, dependente, jamais titular daquilo que diz, porque o que diz reinscreve efeitos próprios do campo enunciativo.

As positividades, em todo caso, não representam determinações que habitam os indivíduos nem se impõem a eles diretamente do exterior, mas condições de exercício de uma prática que dá lugar, inclusive, a novos enunciados capazes de modificá-la (FOUCAULT, 2002, p.236237). Implica dizer que as relações discursivas nem são próprias ao discurso, como se resultassem dos vínculos entre as frases ou proposições, nem muito menos externas, ou seja, "'circunstâncias' exteriores susceptíveis de coagir o discurso." (LECOURT, 1971, p.51) Nessas condições, por paradoxal que seja, o discurso não pode ser confundido meramente com a reprodução de outro discurso, anterior a ele e determinado pelas "relações de produção e a estrutura sócio-política que delas diretamente deriva" (BAKHTIN, 1988, p.42).

Começa pelo fato de que, apesar de compreender um conjunto de elementos que o antecedem, todo enunciado tem o poder de reorganizá-los e redistribuí-los de acordo com as novas relações possíveis de estabelecer. Soma-se a isso o fato de que, em meio a uma mesma prática discursiva, pode ser possível emitir opiniões, fazer escolhas 
e falar de objetos totalmente opostos. A análise arqueológica, salienta Foucault (2002, p.160), "define tipos e regras de práticas discursivas que atravessam obras individuais, às vezes as comandam inteiramente e as dominam sem que nada lhes escape; mas às vezes, também, só lhes regem uma parte."

Ademais, todo sujeito faz parte de uma comunidade discursiva que produz, faz circular, se reconhece e se reúne em nome de determinados discursos regidos pelo mesmo sistema de formação, mas que não torna essa comunidade simplesmente um agrupamento de porta-vozes. Não sendo possível afirmar, portanto, que todos os indivíduos que aderem a um discurso apresentem grau semelhante de assujeitamento. Mais importante do que associar um conjunto de textos a uma dada formação, adverte Maingueneau (1993, p.105), é "compreender como, em determinado lugar, uma população de autores pôde produzir enunciados similares, partilhar um conhecimento tácito das fronteiras de uma formação discursiva, sabendo o que pode ou não ser dito aí." O que parece mais provável é se tratar da emergência de uma "competência discursiva" que, longe de representar simplesmente a impregnação, imitação ou repetição do discurso, dá-se pelo acesso a um sistema de regras, capaz de produzir e interpretar novos enunciados, ainda que dependentes do "mesmo" discurso.

Retomando o pensamento althusseriano, Pêcheux (1988, p.145) explica que essas contradições se devem, sobremaneira, ao fato de que os AIE não podem ser reduzidos a meros instrumentos da classe dominante, a serviço da reprodução das relações de produção existentes. Ao contrário, eles representam a instância importante de uma luta de classes que projeta a luta de classes em geral. 
"Se os aparelhos ideológicos de Estado têm a função de inculcar a ideologia dominante, isso quer dizer que existe resistência, se há resistência, é que há luta e essa luta é, em definitivo, o eco direto ou indireto, próximo ou, em geral, longínquo, da luta de classes." (ALTHUSSER, 1992, p.112) Contraditória e simultaneamente, os AIE constituem o lugar e as condições ideológicas da reprodução/ manutenção e da transformação/revolução das relações de produção.

Apoiando-se em Henry (1974), Pêcheux (1988, p.216) ressalva que o processo de interpelação ou assujeitamento pressupõe considerar o desdobramento do sujeito do discurso em três diferentes modalidades. A começar por aquela mais evidente que se refere à mera identificação ou superposição entre o sujeito da enunciação e o sujeito universal, caracterizada pelo discurso do "bom sujeito" que, sofrendo cegamente as determinações da FD, reflete de forma "livremente consentida" aquele Sujeito. Segue-se a essa modalidade o discurso do "mau sujeito" que irrompe contra aquilo que o sujeito universal lhe designa a pensar e falar, não mais através de um processo de superposição, mas de separação que implica contestação, contra-identificação e contradiscurso à FD que o interdiscurso teima em impor.

Apesar de apontar para dispositivos de experimentação-transformação da história sob perspectiva marxista-leninista, a terceira modalidade de sujeito do discurso funciona, por seu turno, com base em um processo de desidentificação ou tomada de posição não-subjetiva, mas nunca de dessubjetivação ou desassujeitamento. Em outras palavras, nem ocorre aí anulação da forma-sujeito nem desaparecimento da ideologia; "ao contrário, funciona de certo modo às avessas, isto é, sobre e contra si 
mesma, através do 'desarranjo-rearranjo' do complexo das formações ideológicas (e das formações discursivas que se encontram intricadas nesse complexo)." (PÊCHEUX, 1988, p.217-218) Como a tomada de posição nas diferentes modalidades diz respeito à forma-sujeito dominante, a desidentificação não trata de uma dessubjetivação que torna o sujeito livre, mas de uma identificação a outra forma-sujeito, no caso, secundária ou não-dominante.

Esse entrecruzamento entre formações discursivas e formas-sujeito, aliás, é precedido por uma dupla heterogeneidade. Por um lado, uma FD que comporta mais de um discurso em um só, representando a contradição um princípio constitutivo de toda formação (COURTINE, 1982, p.245). Por outro, uma forma-sujeito que no seu interior já encerra diferença e ambigüidade, dividindo-se entre diferentes posições de sujeito que a FD pressupõe e que representam modalidades particulares da identificação do sujeito da enunciação ao sujeito do saber (COURTINE, 1981). Com efeito, a própria noção de uma FD homogênea “transforma-se para abrigar a diversidade de saberes que essa dispersão de posições-sujeito instaura, tornando-se um domínio de saber heterogêneo e dividido em relação a si mesmo." (INDURSKY, 2000, p.76)

Em última instância, essa heterogeneidade acaba afetando a própria ideologia, uma vez que as várias posições que o sujeito assume estão vinculadas a diferentes formações discursivas e, por extensão, a mais de uma formação ideológica. O que implica que o sujeito, no mais das vezes, apresenta-se ideologicamente heterogêneo e contraditório e que o discurso, com efeito, não se relaciona à ideologia de maneira uniforme. Todavia, ressalvam Orlandi e Guimarães (1988, p.33), a formação dominante que regula as posições do sujeito no discurso "propicia-lhe unidade." 
Até porque, como reconhece Indursky (2000, p.77), continua sendo a forma-sujeito que organiza o saber da FD, determinando assim "o que permanece fora de suas fronteiras"

Convém lembrarmos, ainda assim, que Pêcheux (1990c, p.56-57) nos chama atenção para a importância do acontecimento, ignorado e submetido à FD, uma espécie de "máquina de assujeitamento" capaz de se repetir indefinida e independentemente das circunstâncias discursivas. Todo discurso, entretanto, carrega em si a potencialidade de desestruturação, reestruturação ou agitação, constituindo não apenas efeito, mas também um trabalho consciente ou inconsciente de deslocamento das filiações de identificação. Dessa forma, não há identificação absoluta nem relação sócio-histórica que não possa ser afetada "por uma 'infelicidade' no sentido performativo do termo - isto é, no caso, por um 'erro de pessoa', isto é, sobre o outro, objeto da identificação." (MICHEL, 2006)

A capacidade de reação do sujeito ao discurso dominante é possível, sobretudo, através de uma ação dialética que lhe permita negociar e fazer novas interpretações. Pêcheux (1990c, p.17) concebe o acontecimento discursivo, exatamente, como "o ponto de encontro entre uma atualidade e uma memória", capaz de reorganizar as práticas discursivas. $\mathrm{O}$ acontecimento rompe com os rituais de enunciação, funcionando como o lugar por essência onde o real da língua e o real do discurso se juntam, para produzir novas posições enunciativas que não apenas reconfiguram o próprio discurso, como também "participam do processo de produção do real histórico." (ZOPPIFONTANA, 1997, p.51)

Acontece que não podemos ignorar, igualmente, que os signos (leiamos enunciados e discursos) emergem dos 
processos de interação entre os indivíduos, em especial, entre uma consciência individual e uma outra, ambas por si já repletas de signos. A consciência individual, por assim dizer, apenas e tão somente torna-se consciência quando impregnada de conteúdo ideológico, instituído através de relações que pressupõem que os indivíduos estejam organizados em torno de um grupo ou outra forma de organização social: "só assim um sistema de signos pode constituir-se. A consciência individual não só nada pode explicar, mas, ao contrário, deve ela própria ser explicada a partir do meio ideológico e social." (BAKHTIN, 1988, p.34)

Comentando um dos desafios foucaultianos, Lecourt (1971, p.50) já assinalava que a história dos acontecimentos discursivos não pode deixar de ser analisada "como estruturada por relações materiais que se encarnam em instituições." O discurso em torno da política nacional de educação a distância, embora constituído e reconstituído por uma série de acontecimentos discursivos, dificilmente poderia se encontrar desencarnado, ou mesmo, desidentificado do aparato burocrático-institucional. Emana o discurso oficial não de qualquer instituição, mas de uma estrutura extremamente complexa - o Estado brasileiro que, a despeito de regimes menos ou mais democráticos, tende-lhe imprimir por natureza um caráter autoritário, ainda que venhamos a considerar que incidiria sobre o mesmo uma luta contínua entre a formação dominante e outras não menos importantes formações discursivas e ideológicas.

O que nos permite concluir que o discurso em torno da política nacional de educação a distância, especialmente no período que vai dos anos 1950 até a presente década, encontra-se assujeitado à formação discursiva que refere 
a industrialização do ensino. Por que então, cabe ressaltarmos finalmente, os vestígios ou fragmentos da industrialização do ensino mantêm-se e tendem a transcender esse longo tempo? Porque, mediante o interdiscurso, permitem àquela FD reger ou presidir o discurso enquanto estrutura que permanece ou mantém uma continuidade (memória discursiva), a despeito do funcionamento do intradiscurso. De fato, o acontecimento discursivo mostra-se capaz de reformular a estrutura, só que até onde se faz necessário à FD dominante atualizar-se, isto é, continuar governando o discurso em meio a outras formações discursivas. 



\section{CONSIDERAÇÕES FINAIS}

O estudo ora apresentado parte da tese de que o discurso da industrialização do ensino governa a prática discursiva que norteia a política nacional de educação a distância. Os resultados a que chegamos confirmam nossa tese, demonstrando em síntese que o chamado paradigma industrial da EAD põe ordem ao discurso oficial relativamente à educação a distância. Além de orientar teoricamente, a industrialização do ensino assume papel destacado de formação discursiva dominante das práticas enunciativas em torno da EAD, capitaneadas pelo Estado brasileiro.

A abrangência do universo de estudo - a política nacional de EAD - foi determinante para escolhermos o nosso referencial teórico e metodológico. Por um lado, a noção de industrialização do ensino mostrou-se essencial para darmos conta do discurso em torno dessa política, um fenômeno inscrito no âmbito macro das ações em EAD. Logo de início, nossas pesquisas evidenciaram que, em meio às principais abordagens teóricas no campo da educação a distância, a concepção representava aquela cujo arcabouço permitia realizarmos uma análise ampla e aprofundada acerca dos condicionamentos industriais da EAD. 
Repousa a importância daquela noção na compreensão da EAD como a forma mais industrializada de ensino. Enquanto a educação presencial configura um modelo pré-industrial, ainda que afetado por influências da industrialização (a exemplificar a inserção gradativa das tecnologias educacionais), a EAD caracteriza-se tipicamente por se estruturar em moldes industriais. Incorporando e ajustando o campo pedagógico, pois, às injunções e padrões da produção industrial, marcada pelos princípios da divisão de trabalho, mecanização, linhas de montagem, produção de massa, trabalho preparatório, planejamento, organização, mudança de função e especialização, métodos de controle científicos, formalização, padronização, objetivação, concentração e centralização.

Por outro lado, revelou-se de extrema relevância igualmente adotarmos como referencial teórico-metodológico a Análise de Discurso de orientação francesa. Primeiro, porque reside seu mérito na relação que estabelece sempre entre o texto e o contexto sócio-histórico. Segundo, porque concebe o discurso como configurando práticas que não se reduzem a manifestações de formações discursivas, mas são potencialmente capazes de atualizar e, até mesmo, fundar novas FDs. Terceiro, porque a AD considera essas práticas discursivas não apenas no bojo das práticas sociais em geral, destacando-se aquelas de natureza política, como também exercendo um papel tão ou, às vezes, mais importante que estas.

Empregada conjuntamente à noção de industrialização do ensino, a $\mathrm{AD}$ nos ajuda a reconhecer a educação a distância como referindo uma das práticas discursivas mais caras à sociedade contemporânea. Como diria Bakhtin (1988, p.45), a EAD transformou-se em elemento fundamental de enunciação, assumindo um lugar 
destacado "no domínio da ideologia". A EAD, ou melhor, a industrialização do ensino, acrescentaria Foucault (2004, p.17), constitui a formação discursiva que ganhou status de "vontade de verdade" da pedagogia e da política educativa, no século XXI.

Dessa forma, o discurso político-pedagógico hodierno se encontraria, direta e indiretamente, em função da dominação, manutenção e legitimação da EAD, não só no Brasil como em todo o mundo, consolidando progressivamente a profecia de Lévy (2000, p.170) de que a aprendizagem a distância tornar-se-ia "a ponta de lança" do sistema de ensino. Para compreendermos esse tipo de discurso, considerando inclusive a "autoridade" aí investida, precisamos retomar a tese de Althusser (1992, p.77) de que a escola constitui o AIE que predominou nas formações capitalistas avançadas. Levando em conta a procedência da tese althusseriana, não seria pretensioso supor que a EAD representa o aparelho ideológico de Estado que assumiu a posição dominante na formação capitalista contemporânea (muitas vezes, denominada sociedade pós-industrial).

A problemática fundamental da $\mathrm{AD}$, no nosso caso, é compreender o que tornou possível prevalecer a EAD, em suma, o que tem sido permitido dizer sobre este objeto do discurso (GREGOLIN, 2000, p.17). Contraditoriamente, é justo da industrialização do ensino como formação discursiva, ou mesmo, vontade de verdade "que menos se fala." (FOUCAULT, 2004) Não estranha o fato de que apenas um capítulo do livro de Peters "A estrutura pedagógica da educação a distância: investigação sobre uma forma industrializada de ensino e aprendizagem", publicado em 1973, tenha se tornado visível e ganhado repercussão. Os quatro capítulos subseqüentes que continham o aprofundamento teórico do conceito de industrialização 
do ensino (ironicamente, a abordagem mais referida na literatura mundial) permaneceram ignorados, em parte porque não haviam sido traduzidos em inglês (PETERS, 1994).

Reflete esse ocultamento, decerto, uma política do silêncio que faz questão de apagar sentidos indesejáveis ao discurso (ORLANDI, 1997, p.75). Como é da natureza do discurso em geral apresentar-se opaco, o discurso da industrialização do ensino também não se revela diretamente nas práticas discursivas que norteiam a política nacional de EAD. Além de abusar do emprego de metáforas, metonímias e outras figuras de linguagem, que, se por um lado, enriquecem o poder de sedução, minimizam por outro a transparência do discurso, o corpus discursivo que pesquisamos não nos diz, de forma automática, o que, no fundo, estaria a nos dizer (na verdade, determinado, condenado, assujeitado a nos enunciar).

Razão pela qual não se mostrou pouco complexo darmos conta do objetivo geral deste estudo que se propunha a analisar como a industrialização do ensino constitui-se em formação discursiva dominante do discurso em torno da política de EAD. O maior desafio, neste sentido, foi colocar em prática a pressuposição de que essa política configura-se como um dispositivo de institucionalização da industrialização do ensino no país. Para tanto, tivemos que apreender não só as regularidades do discurso oficial, bem como suas estratégias visando mascarar continuidades e não deixar escapar descontinuidades discursivas.

Sobressai, em primeiro lugar, a estratégia em se revestir o discurso de ideologias políticas, expressas mediante políticas educativas vinculadas a formas específicas e circunstanciais assumidas pelo Estado. Melhor dizendo, ora essas políticas são atreladas ao Estado de Bem Estar Social, 
ora ao Estado Gestor, ora ao Estado Neoliberal. Quando na verdade, guardadas as suas devidas especificidades espaço-temporais, o Estado contemporâneo continua o mesmo, incluindo o Estado brasileiro, inscrevendo-se globalmente num modo de produção capitalista, por natureza, liberal, de onde emanam as injunções econômicas que orientam, em grande parte, as políticas sociais.

Reveste-se esse discurso, outras vezes, de reformas pragmáticas que objetivam reestruturar o sistema educativo. Na forma de leis, diretrizes ou planos, essas reformas são justificadas, quase sempre, sob o pretexto de ser imprescindíveis ao desenvolvimento e à soberania nacional. O exame de tais ações, ao longo das últimas décadas, assinala que, praticamente, a cada governo ou regime, democrático ou autoritário, uma política ou programa de EAD chegou, pelo menos, a ser planejado. Na realidade, seguindo Bauman (2005, p.41), trata-se de uma condição sine qua non que não se limita ao Estado brasileiro nem tampouco à contemporaneidade: "A modernidade é uma condição da produção compulsiva e viciosa de projetos."

Donde decorre a pretensão de cada texto pesquisado em fundar, ainda que apenas do ponto de vista discursivo, a política de EAD no país. À exceção do T8, que, necessariamente, faz referência ao T9 que lhe dá origem, os textos no geral parecem sempre inaugurar uma nova política, fazendo questão de ignorar a própria continuidade político-institucional a que estão atrelados, destacando-se nesse sentido os textos 5, 6 e 7 que remontam o Regime Militar. Não fosse, em particular, o reconhecimento do sucesso da SEED, criada em 1995, ainda durante o governo Fernando Henrique Cardoso, o T1 encerraria o discurso, por excelência, de que nunca na história deste país teria sido criado um projeto como o Sistema $\mathrm{UAB}$, um marco histórico para a educação a distância no País. 
Conforme demonstrado no Capítulo 4, a partir do exame de suas condições de produção é que começamos a desconfiar, mais concretamente, dessa opacidade e pretensa descontinuidade do discurso. Considerando o próprio título dos textos pesquisados, logo percebemos quatro discursos que se fazem presentes em quase todo o nosso corpus discursivo: as tecnologias educacionais, a formação continuada, a democratização da educação e a qualidade do ensino. Num primeiro momento, conseguimos vislumbrar uma regularidade tal que não se estabelece de forma aleatória, porém resulta das injunções de um sistema de enunciabilidade que elege os temas essenciais a serem vinculados e pronunciados por parte da política de EAD.

Encontramos esse sistema, evidentemente, atrelado a uma formação ideológica inspirada, ao que parece, na conjuntura nacional e global. A política de EAD dos anos 2000, inserida em um contexto de globalização da economia e centralidade da informação, da comunicação e do conhecimento, não seria a mesma, por exemplo, da década de 1950, em que grassa no país ainda fortemente rural e com grande contingente de analfabetos o nacional-desenvolvimentismo. De sorte que não haveria, em princípio, relação tão significativa entre, respectivamente, uma política que privilegia a democratização da educação superior e formação inicial e continuada de professores e uma política cuja ênfase recai sobre a educação e o treinamento por correspondência.

Aprofundando a análise, vamos perceber todavia que se repetem entre os discursos duas idéias centrais - educação e formação continuada/treinamento, em suma, educação e qualificação profissional. Sob a alegação de democratizar o ensino e promover a educação continuada, os textos 
acabam convergindo numa mesma direção. Tanto a formação discursiva como a formação ideológica que, à primeira vista, presidiriam o T1 e o T10 separadamente, encontram-se na realidade condicionadas a um sistema amplo que suplanta as conjunturas locais e globais, configurando uma estrutura sócio-histórica bem mais complexa - a formação social que, por seu turno, impõe e assegura a própria transcendência da formação ideológica e discursiva sobre os discursos.

O conceito marxista de formação social é fundamental nesse sentido, uma vez que "reflete o grau de desenvolvimento da sociedade" (INOZEMTZEV, 2002). Isso evita que confundamos formação social e modo de produção, constituindo este último a estrutura econômica da sociedade, ou melhor, a sua formação econômica. O modo de produção caracteriza, mais precisamente, a interrelação estabelecida entre as forças produtivas (recursos naturais, instrumentos ou meios de produção e força de trabalho) e as relações de produção, os vínculos que se dão entre os homens no processo produtivo, baseados na propriedade dos meios de produção. De sorte que não é o modo de produção, mas a formação social que abrange a totalidade das manifestações da sociedade, incluindo a superestrutura, onde se destaca a figura do Estado (VITALE, 198-, p.3). Sem reconhecer, portanto, o papel da formação social e, por extensão, do modo de produção capitalista sobre a conformação do Estado contemporâneo, não seria possível compreendermos como a educação e, em particular, a qualificação profissional atravessa de um extremo a outro o nosso corpus discursivo, independentemente da conjuntura onde se inscreve o discurso em torno da política de EAD. 
Como já esclarecia Weber no início do século XX, o treinamento e a especialização assumem papel fundamental na formação do Estado moderno, tornando-se responsáveis pela capacitação da burocracia, a forma mais racional de profissionalização e dominação que toma a frente da administração das grandes empresas e do aparato estatal (WEBER, 1963b, 1994). Não por acaso, enquanto o T10 é patrocinado pelo DASP, além de representar o discurso oficial da SEED o T1 coloca-se a serviço do Sistema UAB, a forma mais racional de capacitação do quadro docente da rede pública de ensino encontrada pelo Estado brasileiro, em pleno século XXI.

Constitui o quadro burocrático, por sinal, o sujeito que em nome desse Estado produz o discurso em torno da política nacional de educação a distância. À exceção do T5, que teria sido enunciado pelo presidente da República (ainda que, não necessariamente, escrito por ele próprio), todos os demais textos são produzidos e/ou organizados por burocratas, pertencentes aos quadros do MEC e outros ministérios, secretarias e órgãos ligados ao Governo Federal. Consiste este último no responsável direto e mais amplo por assumir a autoria e, muito mais ainda, a autoridade sobre cada texto, até porque representa, em última instância, o sujeito universal (Estado brasileiro, Estado moderno, assim por diante).

Ocupando a "forma-sujeito" (ALTHUSSER, 1992) que "sempre-já" lhe foi reservada por aquele Sujeito (PÊCHEUX, 1988), o burocrata portanto é convocado a exercer até as últimas consequiências a racionalidade na qual se reveste seu cargo, desempenhando o papel de engrenagem no mecanismo que põe em movimento o discurso. Aliás, somente ele está autorizado legal, institucional e legitimamente a assumir a palavra oficial, da forma 
a mais objetiva e impessoal possível, mantendo inclusive em segredo seu conhecimento: "na medida em que pode, oculta seu conhecimento e ação da crítica." (WEBER, 1963b, p.269)

Ocultamento este que se estabelece, muitas vezes, no próprio discurso, mediante o emprego de jogos de linguagem e estratégias discursivas, algumas conscientes, outras nem sempre conscientes ao sujeito falante. Evidenciando o papel determinante do interdiscurso no processo discursivo, manifestam elas mais propriamente a incidência do sistema de enunciabilidade que, ao mesmo tempo em que necessita produzir, difundir e pôr em circulação o discurso, distingue e regula aquilo que pode e aquilo que jamais pode ser dito, além de por quem, a quem, por que, como, quando e em que lugar deve ser dito. A própria natureza do nosso corpus discursivo, na essência documentos e publicações oficiais, diz muito acerca dessas injunções da formação discursiva dominante sobre a situação de enunciação.

Caracteriza essa situação, logo de início, um lugar e um tempo estrategicamente determinados. Situam-se os textos pesquisados no contexto imediato da capital federal (Rio de Janeiro e, em sua maioria, Brasília), onde se dão as práticas discursivas e não discursivas mais importantes à vida nacional e, em particular, à política educativa em geral. Mais precisamente, os textos são produzidos sob a égide dos aparelhos de Estado, a destacar o MEC e as secretarias e outros órgãos a ele subordinados. Exceção acontece ao T8 e T9, cuja produção é deslocada para o interior do Estado de São Paulo, onde se concentra a Comissão Nacional de Atividades Espaciais, responsável pela concepção das interfaces das telecomunicações com outras áreas do desenvolvimento e da soberania nacional, 
como a EAD. O atual INPE, inclusive, mantém como um de seus objetivos estratégicos: "Promover uma política espacial para a indústria visando atender às necessidades de desenvolvimento de serviços, tecnologias e sistemas espaciais. $\square$ (BRASIL, 2008b)

O tempo em que ocorre essa produção, não obstante, é consideravelmente variado, estendendo-se ao longo de seis décadas - dos anos 1950 aos anos 2000. Atravessa, inclusive, dois séculos em que o mundo e o país vivem transformações econômicas, políticas, sociais e culturais, talvez, sem precedentes. A chamada revolução das TICs, a centralidade do conhecimento e a mundialização da cultura, capitaneadas pela globalização da economia, reclamam aos Estados nacionais políticas educativas à altura das necessidades aí geradas. Desde a ênfase do T10 à educação e o treinamento por correspondência, passando pelo Projeto Saci do T9 e T8, TV Escola do T3 e T2, até o Sistema $\mathrm{UAB}$ do T1, nosso corpus manifesta em geral, do ponto de vista discursivo, as respectivas respostas e ajustes do Estado brasileiro às exigências conjunturais e estruturais de uma sociedade capitalista e, muito mais ainda, de seu modelo industrial, em pleno processo de reestruturação.

Apesar de, em princípio, condicionado a uma forma-sujeito que ocupa esse espaço-tempo, conseguimos dimensionar o sujeito da enunciação. Configurando o modelo típico da burocracia estatal, o sujeito do T1, particularmente, trata de um profissional considerado altamente especializado, com pós-graduação e que assume um lugar destacado no ambiente acadêmico-pedagógico. Além disso, exerce a posição privilegiada de chefiar e dirigir a SEED, instância central de condução da política de EAD no país e, por extensão, de produção, difusão e circulação do discurso que a orienta. 
Tais características revelam um sujeito concretamente determinado que, inclusive, situa-se na enunciação, mesmo utilizando o pronome de terceira pessoa do plural nós que pode referir alguém acima dele (o sujeito universal). De todo modo, essa condição lhe confere a prerrogativa de constituir um sujeito competente e autorizado para falar em nome do Estado e da sua política de EAD. Quando acrescentamos a isso o fato de ocupar uma posição, investida em um cargo para o qual foi nomeado por um governo eleito pela nação, encontramos também um sujeito plenamente legitimado para o exercício das suas funções.

Ao mesmo tempo, porém, deparamo-nos com um sujeito que pode ser considerado destinatário a partir tão somente das próprias referências do sujeito falante. Dirige este seu discurso a uma série de agentes sociais, profissionais e institucionais, chamados parceiros de projetos e transformados, idealmente, em instâncias de interlocução. Muito embora referido em um artigo de natureza acadêmico-científica, em que estariam preservadas a objetividade e imparcialidade do discurso, esse eventual interlocutor não consegue expressar de forma minimamente autônoma sua voz.

Por um lado, mesmo empregando uma linguagem didática e uma estratégia discursiva de inspiração dialógica, em alusão decerto ao educador Paulo Freire (convidado a assinar, na forma de homenagem póstuma, a epígrafe da coletânea escrita por colaboradores do MEC que origina e abriga o T1), o locutor atribui ao destinatário a posição de um sujeito apenas convocado quando interessa, a exemplo de outros aparelhos de Estado; quando não, é sumariamente silenciado. Por outro, contrariando ironicamente essas pretensas estratégias, o discurso nem 
se caracteriza como lúdico nem tampouco como polêmico, mas como fazendo predominar um caráter autoritário. Um discurso em que a reversibilidade tende a zero, a polissemia se vê contida, prevalece uma assimetria entre as posições dos sujeitos, tem fins pragmáticos e fortes pretensões em impor a verdade (ORLANDI, 1996a).

O discurso autoritário impõe-se, principalmente, quando evidenciamos a sua continuidade em três dimensões - no âmbito do próprio discurso, na sua transcendência enquanto acontecimento discursivo e, por último, na incidência da formação discursiva dominante. Examinando-o do ponto de vista de sua intertextualidade e intradiscursividade, observamos que, além de manter uma regularidade que lhe é peculiar, a sdr 1 já é penetrada, praticamente, por todas as propriedades discursivas caracterizadoras da industrialização do ensino. A própria auto-referência à SEED/MEC e ao Sistema UAB alude, em última instância, condições estruturais da EAD, a destacar a organização industrial, a concentração e a centralização administrativa.

Imprimindo permanente e sistemática circularidade ao discurso, o acontecimento discursivo exerce papel fundamental à repercussão, legitimação e consolidação desses enunciadores retores. Através de sua produção, difusão e circulação em escala cada vez mais abrangente, responde o acontecimento a uma intensa necessidade do discurso oficial em se inscrever sempre tanto em um lugar como em um tempo que vão muito além da superfície lingüística. Quando não assumem estatuto de lei, os textos oficiais são publicados e amplamente divulgados na mídia e nos grandes eventos nacionais especializados, como é o caso do T1, pautando a agenda nacional e gerando novas situações de enunciação que podem resultar seja na 
singularidade, seja na regularidade, seja na descontinuidade do discurso. Nesses termos é que Pêcheux (1990c, p.17) entende o acontecimento discursivo como o ponto culminante em que uma memória se (re)aproxima de uma (nova) atualidade: "é ele que desestabiliza o que está posto e provoca um novo vir a ser, reorganizando o espaço da memória que o acontecimento convoca".

Apesar de fazer essa provocação, pretendendo fundar uma nova história ou política de EAD no país, o que percebemos empreender o T1 na verdade é a reorganização da industrialização do ensino na memória nacional. Ao longo de todo o texto, os seus princípios e condições estruturais são ora afirmados ora reafirmados, configurando um discurso que reforça e legitima, mais fortemente ainda, a EAD como a forma mais racional de democratização da educação superior e formação inicial e continuada de professores. Não demoramos muito a ver seguir-se a esse discurso (que já sucedia outras práticas discursivas e não discursivas) todo um processo de institucionalização e implantação de um novo e arrojado sistema de educação a distância que, por intermédio de "chamadas" e "editais", recebe a adesão crescente das IES públicas e das três esferas governamentais.

A incidência dos fragmentos da industrialização do ensino não se reduz, porém, ao discurso em torno do Sistema UAB, ainda que este represente a ponta do iceberg. Conforme vimos examinando o conjunto dos textos, os vestígios, traços, fragmentos, enunciados da formação discursiva que norteia a política nacional de EAD estendem-se ao longo de seis décadas (para não dizer, há pelo menos um século). Trata-se de um sistema de enunciabilidade que, desde os anos 1950, estabelece a priori o que é prioritário a cada plano, projeto, programa de EAD no 
país. Trata-se, além disso, de um sistema de formação que designa os sujeitos autorizados a falar em nome do Estado acerca de uma política pública estratégica ao desenvolvimento da nação. Trata-se, enfim, de um sistema que tem - até movimento em contrário - determinado a posição ocupada por cada um de nós, nossa "forma-sujeito", nesse cenário discursivo, quicá também, não discursivo.

Com essas considerações, damos por encerrado este estudo que não parece conclusivo, nem por certo gostaríamos que assim o fosse. Concebido como uma prática discursiva, o discurso da política nacional de educação a distância não deixa de representar uma luta permanente. Em face disso, tal discurso pode se mostrar como um fenômeno marcado por continuidades e descontinuidades que colocam em questão, permanentemente, a regularidade do discurso. Tratar-se-ia, no fundo, de uma prática que põe em jogo a materialidade (enunciados e textos) e a exterioridade do discurso (sua historicidade), demonstrando as relações regulares e contraditórias que podem estabelecer o intradiscurso e o interdiscurso e, por extensão, as formações discursivas que - eventualmente - atravessam o fenômeno.

Significaria isso darmos conta, mais profundamente, da prática social na qual o discurso se inscreve, ao lado de outras práticas não-discursivas. A análise da prática política, sem dúvida, é uma das formas mais importantes de compreender a prática social. Antes de tudo, já esclarecia Zedong (1937), a teoria marxista entende a atividade do homem na produção material como representando a sua principal prática em sociedade, aquela que determina todas as demais, inclusive constitui a fonte essencial desde a qual se desenvolve o conhecimento. No decurso da produção material é que vamos compreendendo, 
gradativamente, não só os fenômenos da natureza e nossas relações com a mesma, como também e em diferentes graus as relações estabelecidas entre os próprios homens.

A prática social, todavia, não se resume à atividade na produção, envolvendo ainda a vida política e a vida cultural, estreitamente vinculadas à vida material. Dentre essas formas da prática social, a luta de classes, por sinal em suas manifestações as mais diversas, assume influência profunda sobre o desenvolvimento do conhecimento humano (ZEDONG, 1937). As rupturas nas estruturas e práticas sociais, por isso mesmo, são possíveis, mas (também) parecem se apresentar bastante raras e complexas. Razão pela qual são as potencialidades dessas rupturas ou descontinuidades discursivas que nos interessam desvendar, como objeto de uma pesquisa futura. Sobretudo, no sentido de analisar os seus impactos na constituição de uma (possível) educação a distância "transformadora". 



\section{REFERÊNCIAS ${ }^{23}$}

1985: MENSAGEM apresentada ao Congresso Nacional pelo Presidente da República, João Baptista de Oliveira Figueiredo, na abertura da sessão legislativa. In: BRASIL. Ministério da Educação. Instituto Nacional de Estudos e Pesquisas Educacionais. A educação nas mensagens presidenciais: 1890-1986. Brasília, 1987. v.2. p.513-520.

A ALTERNATIVA para mais de dois milhões de brasileiros. In: ABRAEAD 2007: anuário brasileiro estatístico de educação aberta e a distância. São Paulo: Instituto Monitor/ABED/SEED/MEC, 2007. p.149-154.

ALMEIDA, Edson Pacheco de; PEREIRA, Rosângela Saldanha. Críticas à teoria do capital humano (uma contribuição à análise de políticas públicas em educação). Revista de Educação Pública, Cuibá, n.15, jan./jun. 2000. Disponível em: <http://www.ufmt.br/revista/arquivo/ rev15/AlmeidaPereira.html>. Acesso em: 29 mar. 2008.

23 Para respeitar a localização das fontes de informação referidas (bibliográficas, documentais, institucionais etc.), os endereços eletrônicos foram mantidos conforme a referência adotada originalmente, mesmo no caso daqueles não mais encontrados ativos ou cujo endereço foi alterado. 
ALTHUSSER, Louis. Aparelhos ideológicos de Estado: nota sobre os Aparelhos ideológicos de Estado. 6.ed. Rio de Janeiro: Graal, 1992.

ANDRÉ, Cláudio et al. Pesquisa colaborativa sobre a produção do conhecimento em educação a distância no Brasil, de 1999 a 2006. In: ABRAEAD 2007: anuário brasileiro estatístico de educação aberta e a distância. São Paulo: Instituto Monitor/ABED/SEED/MEC, 2007. p.157-166.

ANTONIO Fonseca Pimentel. Enciclopédia Ouro Fino, Ouro Fino-MG, 3 mar. 2008. Disponível em: <http:// www.eourofino.org.br/index.php?title=Antonio Fonseca_Pimentel>. Acesso em: 15 abr. 2008.

AS INSTITUIÇÕES com maior número de alunos do país. In: ABRAEAD 2007: anuário brasileiro estatístico de educação aberta e a distância. São Paulo: Instituto Monitor/ ABED/SEED/MEC, 2007. p.39-40.

ASSOCIAÇÃO BRASILEIRA DE EDUCAÇÃO A DISTÂNCIA. IV Congresso de Ensino Superior a Distância. São Paulo, 1 jun. 2006. Disponível em: <http:/ / www2.abed.org.br/noticia.asp?Noticia_ID $=127>$. Acesso em: 15 set. 2007.

ASSOCIAÇÃO BRASILEIRA DE EDUCAÇÃO A DISTÂNCIA; UNIVERSIDADE VIRTUAL PÚBLICA DO BRASIL. $6^{\circ}$ Seminário Nacional ABED de Educação a Distância/V Congresso Brasileiro de Ensino Superior a Distância. Gramado-RS, 2008. Disponível em: <http:// www.unirede.br/esud+senaed2008/>. Acesso em 14 mar. 2008. 
ASSOCIAÇÃOUNIVERSIDADEEM REDE. Universidade Virtual Pública do Brasil. Quem somos: histórico da UniRede. Brasília, 2007. Disponível em: <http://www. unirede.br/>. Acesso em 15 set. 2007.

AZEVEDO, Wilson. Didática do ensino a distância: experiências e estágios da discussão numa visão internacional. São Leopoldo-RS, 2001.

BAKHTIN, Mikhail. Estética da criação verbal. São Paulo: Martins Fontes, 1992.

BAKHTIN, Mikhail. Marxismo e filosofia da linguagem: problemas fundamentais do método sociológico na ciência da linguagem. 4.ed. São Paulo: Hucitec, 1988.

BAKHTIN, Mikhail. Problemas da poética de Dostoiévski. 2.ed.rev. Rio de Janeiro: Forense Universitária, 1997.

BARBETA, Vagner B. Alternativas às atividades laboratoriais presenciais em cursos de física na modalidade de EAD. In: BRASIL. Ministério da Educação. Secretaria de Educação a Distância. Desafios da educação a distância na formação de professores. Brasília: SEED/MEC, 2006. p.151-173.

BARONAS, Roberto Leiser. Configurações da memória discursiva em slogans políticos. In: GREGOLIN, Maria do Rosário V. (Org.). Filigranas do discurso: as vozes da história. São Paulo: Cultura Acadêmica, 2000. p. 69-81.

BATISTA, Wagner Braga. Educação a distância e o refinamento da exclusão social. Conect@, Rio de Janeiro, n.4, fev. 2002. Disponível em: <http://www.revistaconecta. com/>. Acesso em: 10 mar. 2004. 
BAUMAN, Zygmunt. Vidas desperdiçadas. Rio de Janeiro: Zahar, 2005.

BELLONI, Maria Luiza. Educação a distância. Campinas: Autores Associados, 1999.

BIELSCHOWSKY, Carlos Eduardo. Educação superior a distância: uma estratégia para avaliação institucional. In: BRASIL. Ministério da Educação. Secretaria de Educação a Distância. Desafios da educação a distância na formação de professores. Brasília: SEED/MEC, 2006. p.51-65.

BORDENAVE, Juan E. Díaz. Teleducação ou educação a distância: fundamentos e métodos. Petrópolis: Vozes, 1987.

BORNHAUSEN, Jorge. Apresentação. In: BRASIL. Ministério da Educação. Instituto Nacional de Estudos e Pesquisas Educacionais. A educação nas mensagens presidenciais: 1890-1986. Brasília, 1987. v.1. p.7-8.

BRASIL e Espanha interagem em prol da EAD. Universia, Brasil, 2 jun. 2006a. Disponível em: <http:/ / www.universia.com.br/materia/materia.jsp?materia $=11091>$. Acesso em 15 set. 2007.

BRASIL. Agência Brasil. Lula diz que governo quer ampliar acesso à educação superior. Brasília, 17 mar. 2008a. Disponível em: <http://www.agenciabrasil.gov. br/noticias/2008/03/17/materia.2008-03-17.7082937609/ view>. Acesso em: 20 mar. 2008.

BRASIL. Conselho Nacional de Pesquisas. Comissão Nacional de Atividades Espaciais. Projeto Saci: relatório no II: parte A. São José dos Campos-SP, 1969. 
BRASIL. Conselho Nacional de Pesquisas. Comissão Nacional de Atividades Espaciais. Projeto Saci: parte I. São José dos Campos-SP, 1968.

BRASIL. Ministério da Ciência e Tecnologia. Instituto Nacional de Pesquisas Espaciais. Sobre o INPE: objetivos estratégicos. São José dos Campos-SP, 2008b. Disponível em: <http://www.inpe.br/institucional/obj_estrategico. php>. Acesso em: 15 abr. 2008.

BRASIL. Ministério da Educação e Cultura. Departamento de Ensino Supletivo. Projeto Logos I: avaliação: o desafio, a experimentação, o resultado. Brasília: Departamento de Documentação e Divulgação/MEC, 1975a.

BRASIL. Ministério da Educação e Cultura. Departamento de Ensino Supletivo. Projeto Logos II. Brasília: Departamento de Documentação e Divulgação/MEC, 1975b.

BRASIL. Ministério da Educação e Cultura. SecretariaGeral. II Plano Setorial de Educação e Cultura: (1975/1979). Brasília, 1976.

BRASIL. Ministério da Educação e Cultura. SecretariaGeral. Programa Nacional de Teleducação. Relatório da teleducação. Brasília, 1973.

BRASIL. Ministério da Educação e do Desporto. Secretaria de Educação a Distância. Relatório 1996. Brasília, 1996.

BRASIL. Ministério da Educação e do Desporto. Secretaria de Educação Fundamental. Departamento de Políticas Educacionais. Coordenação de Educação a Distância e Continuada. Educação aberta, continuada e a distância: 
um novo cenário para a educação brasileira: relatório-síntese 1990-1994. Brasília, 1994.

BRASIL. Ministério da Educação. Assessoria de Comunicação Social. Ministério lança curso de especialização a distância em Tecnologias na Educação. Portal MEC, Brasília, 20 jun. 2006b. Disponível em: <http:/ / portal.mec.gov.br/acs/index.php?option=com_content\&task=view\&id=6524\&interna=6>. Acesso em: 15 set. 2007.

BRASIL. Ministério da Educação. Assessoria de Comunicação Social. Três programas do MEC estão entre as dez palavras mais procuradas na internet. Portal MEC, Brasília, 9 fev. 2007a. Disponível em: <http:/ / portal.mec. gov.br/index.php?option=com_content\&task=view\&interna $=1 \& \mathrm{id}=7685>$. Acesso em: 12 mar. 2007.

BRASIL. Ministério da Educação. Assessoria de Comunicação Social. MEC lança novo portal na internet. Portal MEC, Brasília, 25 nov. 2004a. Disponível em: $<$ http:// mec.gov.br/acs/index.php?option=com_content\&task=view\&id=1556\&interna=6>. Acesso em: 12 mar. 2007.

BRASIL. Ministério da Educação. Assessoria de Comunicação Social. Portal Domínio Público oferecerá três mil novos títulos por mês. Portal MEC, Brasília, 11 dez. 2006c. Disponível em: <http://portal.mec.gov.br/ acs $/$ index.php?option $=$ com_content $\&$ task $=$ view \&id=7415\&interna=6>. Acesso em: 28 out. 2007.

BRASIL. Ministério da Educação. Assessoria de Comunicação Social. Ministro destaca importância da educação a distância. Portal MEC, Brasília, 17 maio 2006d. 
Disponível em: <http://portal.mec.gov.br/acs/index. php?option $=$ com_content $\&$ task $=$ view $\& i d=6263 \&$ in terna=6>. Acesso em: 15 dez. 2007.

BRASIL. Ministério da Educação. Instituto Nacional de Estudos e Pesquisas Educacionais. Introdução. In:

A educação nas mensagens presidenciais: 1890-1986. Brasília, 1987. v.1. p.9-11.

BRASIL.MinistériodaEducação.InstitutoNacionaldeEstudose Pesquisas Educacionais Anísio Teixeira. Centro de Informação e Biblioteca em Educação. Bibliografias Temáticas. Brasília, 2007b. Disponível em: <http:/ / www. inep.gov.br/pesquisa/bibliografia/>. Acesso em: 10 set. 2007.

BRASIL. Ministério da Educação. Secretaria de Educação a Distância. Assessoria de Imprensa da Seed. Cead/UnB promove curso de especialização em educação a distância. Portal MEC, Brasília, 25 maio 2006e. Disponível em: $<$ http:/ / portal.mec.gov.br/seed/index.php?option=com_content\&task $=$ view\&id $=6350 \&$ interna $=6>$. Acesso em 15 set. 2007.

BRASIL. Ministério da Educação. Secretaria de Educação a Distância. Assessoria de Imprensa da Seed. MEC lança curso de especialização a distância em tecnologias na educação. Brasília, 16 jun. 2006f. Disponível em: <http:/ / portal.mec.gov.br/seed/index.php?option=com_content\&task=view\&id $=6512 \& i n t e r n a=6>$. Acesso em: 15 set. 2007.

BRASIL. Ministério da Educação. Secretaria de Educação a Distância. Assessoria de Imprensa da Seed. Educação a 
distância do Brasil é reconhecida em evento internacional. Portal MEC, Brasília, 4 maio 2006g. Disponível em: $<$ http:/ / portal.mec.gov.br/seed/index.php?option=com_content\&task=view\&id=6142\&interna $=6>$. Acesso em 15 set. 2007.

BRASIL. Ministério da Educação. Secretaria de Educação a Distância. Assessoria de Imprensa. Políticas públicas para expansão do ensino superior a distância é tema do Esud. Seednet, Brasília, 17 maio 2006h. Disponível em: $<$ http://www.seednet.mec.gov.br/noticias.php?codmateria $=980>$. Acesso em: 15 set. 2007.

BRASIL. Ministério da Educação. Secretaria de Educação a Distância. Assessoria de Imprensa da SEED. UAB crescerá 93\% em 2008. Portal MEC, Brasília, 24 jan. 2008c. Disponível em: <http://portal.mec.gov.br/seed/index. php?option $=$ com_content\&task $=$ view $\&$ id $=9806 \&$ in terna=6>. Acesso em: 24 jan. 2008.

BRASIL. Ministério da Educação. Secretaria de Educação a Distância. Estrutura organizacional. Portal MEC, Brasília, 2007c. Disponível em: <http://portal.mec.gov.br/seed/ index.php?option $=$ content $\&$ task $=$ view $\&$ id $=133 \&$ Itemid=269> Acesso em: 25 de set. 2007.

BRASIL. Ministério da Educação. Secretaria de Educação a Distância. WebEduc: o Portal de Conteúdos Educacionais do MEC. O que você irá encontrar? Brasília, 2007d. Disponível em: <http://webeduc.mec.gov.br/>. Acesso em: 20 mar. 2007.

BRASIL. Ministério da Educação. Secretaria de Educação a Distância. Programa de Formação Continuada em 
Mídias na Educação. Mídias na Educação. Portal MEC, Brasília, 2007e. Disponível em: <http://portal.mec.gov. br/seed/index.php?option $=$ com_content\&task $=$ view\&id=199\&Itemid=>. Acesso em: 13 mar. 2007.

BRASIL. Ministério da Educação. Secretaria de Educação a Distância. Programa de Formação Continuada em Mídias na Educação. Apresentação. Brasília, 2007f. Disponível em: <http://www.webeduc.mec.gov.br/midiaseducacao/ modulo1/index.htm>. Acesso em: 20 set. 2007.

BRASIL. Ministério da Educação. Secretaria de Educação a Distância. Portal Domínio Público. Publicações sobre Educação: resultado da pesquisa. Domínio Público, Brasília, 2008d. Disponível em: <http://www.dominiopublico.gov.br/pesquisa/ResultadoPesquisaObraForm. do>. Acesso em: 25 jan. 2008.

BRASIL. Ministério da Educação. Secretaria de Educação a Distância. Política e resultados 1995-2002: tecnologias na educação básica. Brasília, 2002a.

BRASIL. Ministério da Educação. Secretaria de Educação a Distância. 2 anos da TV Escola: Seminário Internacional: 1998. Brasília, 1999.

BRASIL. Ministério da Educação. Secretaria de Educação a Distância. TV Escola: relatório 1996-2002. Brasília, 2002b.

BRASIL. Ministério da Educação. Secretaria de Educação a Distância. Balanço Geral da União: 2005. Brasília [2006g].

BRASIL. Ministério da Educação. Secretaria de Educação a Distância. Edital n ${ }^{\circ} 1$, de 16 de dezembro de 2005: chamada pública para seleção de pólos municipais de apoio 
presencial e de cursos superiores de Instituições Federais de Ensino Superior na modalidade de educação a distância para o "Sistema Universidade Aberta do Brasil-UAB". Diário Oficial da União, Brasília, n.243, 20 dez. 2005a, Seção 3, p.39-41.

BRASIL. Ministério da Educação. Secretaria Nacional de Educação Básica. Departamento de Ensino Fundamental e Médio. Coordenadoria de Educação a Distância. Educação a distância: integração nacional pela qualidade do ensino. Brasília, 1992.

BRASIL. Ministério do Planejamento, Orçamento e Gestão. Assessoria de Comunicação Social. Projeto Formar de cara nova. Contato, Brasília, n.55, 28 abr. 2006h. Disponível em: <http://www.servidor.gov.br/publicacao/boletim_ contato/bol_contato_06/contato_55.htm\#3>. Acesso em: 20 abr. 2008.

BRASIL. Ministério do Planejamento, Orçamento e Gestão. Secretaria de Recursos Humanos. Secretaria de Recursos Humanos-SRH. Brasília, 2008e. Disponível em: <http://www.planejamento.gov.br/recursos_humanos/ index.htm>. Acesso em: 20 abr. 2008.

BRASIL. Presidência da República. Casa Civil. Secretaria Geral. Secretaria de Comunicação de Governo e Gestão Estratégica. Ministério do Planejamento, Orçamento e Gestão. Mensagem ao Congresso Nacional 2003. Brasília, 2003. Disponível em: <http://www.planalto.gov.br/ publi_04/mens2003.htm>. Acesso em: 22 jan. 2008.

CÂMARA DOS DEPUTADOS. Arquivo da Câmara dos Deputados. Apresentação. Brasília, 2007. Disponível 
em: <http://www2.camara.gov.br/internet/biblarq/ arquivo/index.html>. Acesso em: 11 set. 2007.

CARDOSO, Fernando Henrique. Abertura. In: BRASIL. Ministério da Educação. Secretaria de Educação a Distância. 2 anos da TV Escola: Seminário Internacional: 1998. Brasília, 1999. p.9-16.

CARDOSO, Onésimo de Oliveira. Comunicação e educação: novos meios, novas idéias. Comunicação e Sociedade, São Bernardo do Campo-SP, v.13, n.22, p.123136, dez.1994.

CATELLI, Rosana Elisa. Cinema e educação em John Grierson. Aruanda, São Paulo, out. 2003. Disponível em: <http://www.mnemocine.com.br/aruanda/cineducemgrierson.htm>. Acesso em: 10 abr. 2008.

CATELLI, Rosana Elisa. O cinema educativo nos anos de 1920 e 1930: algumas tendências presentes na bibliografia contemporânea. Intexto, Porto alegre, n.12, 2005. Disponível em: <http://www.intexto.ufrgs.br/n12/an12a8.htm>. Acesso em: 15 out. 2007.

CAZARIN, Ercília Ana. Afinal quem chegou ao poder na eleição presidencial de 2002? Revista Espaço Acadêmico, Maringá-PR, v.5, n.53, out. 2005. Disponível em: <http:// www.espacoacademico.com.br/053/53cazarin.htm>. Acesso em: 14 out. 2007.

CHARAUDEAU, Patrick. Discurso político. São Paulo: Contexto, 2006. 
CHARAUDEAU, Patrick; MAINGUENEAU, Dominique. Dicionário de análise do discurso. 2.ed. São Paulo: Contexto, 2006.

CHAUI, Marilena. Cultura e democracia: o discurso competente e outras falas. São Paulo: Moderna, 1981.

CHAVES FILHO, Hélio. Apresentação. In: BRASIL. Ministério da Educação. Secretaria de Educação a Distância. Desafios da eduação a distância na formação de professores. Brasília: SEED/MEC, 2006. p.11.

COSTA, Antonio Roberto Faustino da. (Des)Caminhos da educação a distância no Brasil do século XX. João Pessoa, 2001.

COSTA, Antonio Roberto Faustino da. Abordagens teóricas da educação a distância. João Pessoa, 2005. Monografia (Doutorado em Educação) - Centro de Educação, UFPB.

COSTA, Antonio Roberto Faustino da. O discurso da industrialização do ensino na política nacional de educação a distância. João Pessoa, 2008. Seminário de Tese/Exame de Qualificação (Doutorado em Educação) - Programa de Pós-Graduação em Educação, Centro de Educação, Universidade Federal da Paraíba.

COURTINE, Jean-Jacques. Análisis del discurso político: el discurso comunista dirigido a los cristianos. Trad. María del Carmen Saint-Pierre. Langages, v.15, n.62, jun. 1981. Disponível em: <http://www.magarinos.com.ar/ courtine.htm>. Acesso em: 10 out. 2007.

COURTINE, Jean-Jacques. Definition d'orientations théoriques et construction de procédures en Analyse du 
Discours. Philosophiques, Montreal-Canadá, v.9, n.2, p.239-264, oct. 1982. Disponível em: <http:/ / www.erudit. org/revue/philoso/1982/v9/n2/index.html>. Acesso em: 20 out. 2007.

COURTINE, Jean-Jacques. O chapéu de Clémentis: observações sobre a memória e o esquecimento na enunciação do discurso político. In: INDURSKY, Freda; FERREIRA, Maria Cristina Leandro (Orgs.). Os múltiplos territórios da Análise do Discurso. Porto Alegre: Sagra Luzzatto, 1999. p.15-22.

DEVLIN, Lawrence E. 2: distance education as a discipline: a response to Holmberg. Journal of Distance Education, Otawa-Canadá, v.4, n.1, 1989. Disponível em: <http:// www.cade-aced.ca/en_pub.php>. Acesso em: 24 nov. 2004.

DICIONÁRIO brasileiro de terminologia arquivística. Rio de Janeiro: Arquivo Nacional, 2005.

DOSSE, François. História do estruturalismo: o campo do signo: 1945/1966. Bauru-SP: Edusc, 2007. v. 1.

DRAIBE, Sônia Miriam. Há tendências e tendências: com que Estado de Bem Estar Social haveremos de conviver neste fim de século? Caderno de Pesquisa, Campinas-SP, n.10, 1989. Disponível em: <http://www.nepp.unicamp. br/Cadernos/Caderno10.pdf>. Acesso em: 25 maio 2008.

DURKHEIM, Émile. Educação e sociologia. 9.ed. São Paulo: Melhoramentos, 1973.

FAGUNDES, Léa da Cruz. A formação de professores na licenciatura presencial e na licenciatura a distância: 
semelhanças e diferenças. In: BRASIL. Ministério da Educação. Secretaria de Educação a Distância. Desafios da educação a distância na formação de professores. Brasília: SEED/MEC, 2006. p.67-78.

FARIAS, Mônica Façanha. Momentos da educação a distância no Brasil. Educação em Debate, Fortaleza, v.20, n.35, p.89-98, 1998.

FAUSTO NETO, Antônio. Ensinando à televisão: estratégias de recepção da TV Escola. João Pessoa: Ed. Universitária, 2001.

FEDERICO, Maria Elvira Bonavita. História da comunicação: rádio e TV no Brasil. Petrópolis: Vozes, 1982.

FERREIRA, Maria Cristina Leandro. O lugar da sintaxe no discurso. In: INDURSKY, Freda; FERREIRA, Maria Cristina Leandro (Orgs.). Os múltiplos territórios da Análise do Discurso. Porto Alegre: Sagra Luzzatto, 1999. p.60-66.

FERRETTI, Cláudio et al. Projetos de aprendizagem em EAD. In: BRASIL. Ministério da Educação. Secretaria de Educação a Distância. Desafios da educação a distância na formação de professores. Brasília: SEED/MEC, 2006. p.223-236.

FORGET, Danielle. Conquistas e resistências do poder: a emergência do discurso democrático no Brasil (19641984). São Paulo: Edusp, 1994.

FOUCAULT, Michel. A arqueologia do saber. 6.ed. Rio de Janeiro: Forense-Universitária, 2002. 
FOUCAULT, Michel. A ordem do discurso: aula inaugural no Collège de France, pronunciada em 2 de dezembro de 1970. 11.ed. São Paulo: Loyola, 2004.

FOUCAULT, Michel. Diálogo sobre o poder. In: MOTTA, Manoel Barros da (Org.). Michel Foucault: ditos e escritos. Rio de Janeiro: Forense Universitária, 2001a.

FOUCAULT, Michel. O cuidado com a verdade. In: MOTTA, Manoel Barros da (Org.). Michel Foucault: ditos e escritos. Rio de Janeiro: Forense Universitária, 2001b.

FOUCAULT, Michel. Resumo dos cursos do Collège de France: 1970-1982. Rio de Janeiro: Zahar, 1997.

FRANCO, Sérgio Roberto Kieling. O programa PróLicenciatura: gênese, construção e perspectivas. In: BRASIL. Ministério da Educação. Secretaria de Educação a Distância. Desafios da educação a distância na formação de professores. Brasília: SEED/MEC, 2006. p.27-37.

FREIRE, Paulo. Pedagogia da indignação: cartas pedagógicas e outros escritos. São Paulo: Ed. UNESP, 2000.

FUNDAÇÃO GETÚlIO VARGAS. Centro de Pesquisa e Documentação de História Contemporânea do Brasil. Diretrizes do Estado Novo (1937-1945): política e administração. In:

A Era Vargas: $1^{\circ}$ tempo: dos anos 20 a 1945. Rio de Janeiro, 1997. Disponível em: <http:/ / www. cpdoc.fgv.br/nav_historia/htm/anos37-45/ev_poladm_ dasp.htm>. Acesso em: 20 abr. 2008.

FUNDAÇÃO GETÚLIO VARGAS. Escola Brasileira de Administração Pública e de Empresas. Série Cadernos de Administração Pública. Rio de Janeiro [entre 2002 e 
2008]. Disponível em: <http://www.ebape.fgv.br/cadernosebape/asp/dsp_sobre_revista_historico.asp $>$. Acesso em: 20 abr. 2008.

GADET, Françoise et al. Apresentação da conjuntura em lingüística, em psicanálise e em informática aplicada ao estudo dos textos na França, em 1969. In: GADET, Françoise; HAK, Tony (Orgs.). Por uma análise automática do discurso: uma introdução à obra de Michel Pêcheux. Campinas-SP: Ed. Unicamp, 1990. p.39-60.

GADET, Françoise. Prefácio. In: ;HAK, Tony (Orgs.). Por uma análise automática do discurso: uma introdução à obra de Michel Pêcheux. Campinas-SP: Ed. Unicamp, 1990. p.7-11.

GALBRAITH, John Kenneth. O Novo Estado Industrial. 2. ed. São Paulo: Nova Cultural, 1985.

GARRIDO, Susane; SILVA, Janice Theodoro da. Educação a distância: antigos dilemas, novas alternativas. In: BRASIL. Ministério da Educação. Secretaria de Educação a Distância. Desafios da educação a distância na formação de professores. Brasília: SEED/MEC, 2006. p.175-190.

GREGOLIN, Maria do Rosário. AD: descrever - interpretar acontecimentos cuja materialidade funde linguagem e história. In: NAVARRO, Pedro (Org.). Estudos do texto e do discurso: mapeando conceitos e métodos. São Carlos-SP: Claraluz, 2006. p.19-34.

GREGOLIN, Maria do Rosário. Análise do discurso: os sentidos e suas movências. In: et al. (Org.). Análise do discurso: entornos do sentido. São Paulo: Cultura Acadêmica, 2000. 
HADDAD, Fernando. Prefácio. In: BRASIL. Ministério da Educação. Secretaria de Educação a Distância. Desafios da eduação a distância na formação de professores. Brasília: SEED/MEC, 2006. p.7-9.

HENRY, Paul. Os fundamentos teóricos da "Análise Automática do Discurso" de Michel Pêcheux (1969). In: GADET, Françoise; HAK, Tony (orgs.). Por uma análise automática do discurso: uma introdução à obra de Michel Pêcheux. Campinas-SP: Ed. UNICAMP, 1990. p.13-38.

HERNÁNDEZ, José Gpe. Vargas. Los desafíos de la administración pública en América Latina. Estado, Gobierno, Gestión Pública, Santiago-Chile, v.1, n.1, p.18-45, mar. 2002. Disponível em: <http://www.inap.uchile.cl/ gobierno/revista1.html>. Acesso em: 10 out. 2007.

HOLMBERG, Borje. A discipline of distance education. Journal of Distance Education, v.1, n.1, 1986. Disponível em: $\quad<$ http://cade.athabascau.ca/vol1.1/holmberg. html>. Acesso em: 23 nov. 2004.

HOLMBERG, Borje. John Baath 1931-1999: obituary. 1999. Disponível em: <http://tojde.anadolu.edu.tr/tojde1/ baath_news.htm>. Acesso em: 29 nov. 2004.

HOLMBERG, Borje. The evolution of the character and practice of distance education. Open Learning, v.10, n.2, p.47-53, jun. 1995. Disponível em: <http://www.umuc. edu/ide/seminar/holmberg.html>. Acesso em: 24 nov. 2004.

INDURSKY, Freda. A fala dos quartéis e as outras vozes. Campinas-SP: Ed. Unicamp, 1997. 
INDURSKY, Freda. A fragmentação do sujeito em Análise do Discurso. In:___ CAMPOS, Maria do Carmo (Orgs.). Discurso, memória, identidade. Porto Alegre: Sagra Luzzatto, 2000. p.70-81.

INOZEMTZEV, Vladislav. A concepção de Marx sobre a formação social e econômica. Marxismo Vivo, n. 6, nov. 2002. Disponível em: <http://www.marxismovivo.org/ vladislav6port.html>. Acesso em: 15 set. 2007.

JENSEN, Linda. Theories and models in distance education. Arizona State University, Summer 1998. Disponível em: <http://seamonkey.ed.asu.edu/ mcisaac/disted/ week3/10focslj.html>. Acesso em: 22 nov. 2004.

KEEGAN, Desmond. Foundations of distance education. 2.ed. London/New York: Routledge, 1991.

KEEGAN, Desmond. Open learning: concepts and costs, successes and failures. In ATKINSON, R., C. MCBEATH, C. (Eds.). Open learning and new technology: conference proceedings. Perth: Australian Society for Educational Technology WA Chapter, 1990. p.230-243. Disponível em: <http://www.aset.org.au/confs/olnt90/keegan.html>. Acesso em: 22 nov. 2004.

KEEGAN, Desmond. Seamless interfaces: distance education and web-based training. [1998a]. Disponível em: <http://www.nettskolen.com/pub/artikkel.xsql?artid=118>. Acesso em: 23 nov. 2004.

KEEGAN, Desmond. Theoretical analysis of distance training in the European Union. 1998b. Disponível em: <http:/ / www.fernuni-hagen.de/>. Acesso em: 24 nov. 2004. 
KHÔI, Lê Thành. A indústria do ensino. Porto, Portugal: Civilização, 1970.

LAASER, Wolfram (Org.). Manual de criação e elaboração de materiais para educação a distância. Brasília: Ed. UnB, 1997.

LECOMTE, Alain; LÉON, Jacqueline; MARANDIN, JeanMarie. Análise do Discurso: estratégias de descrição textual (1984). In: GADET, Françoise; HAK, Tony (Orgs.). Por uma análise automática do discurso: uma introdução à obra de Michel Pêcheux. Campinas-SP: Ed. Unicamp, 1990. p.283-310.

LECOURT, Dominique. A arqueologia e o saber. In: FOUCAULT, Michel et al. O homem e o discurso: a arqueologia de Michel Foucault. Rio de Janeiro: Tempo Brasileiro, 1971. p.43-66.

LES ÉDITIONS DE MINUIT. Lê Thành Khôi: l'industrie de l'enseignement. Disponível em: <http://www.leseditionsdeminuit.eu/f/index.php?sp=liv\&livre_id=2162\#>. Acesso em: 20 mar. 2008.

LÉVY, Pierre. Cibercultura. 2.ed. São Paulo: 34, 2000.

MAINGUENEAU, Dominique. Análise de textos de comunicação. 2.ed. São Paulo: Cortez, 2002.

MAINGUENEAU, Dominique. Novas tendências em análise do discurso. 2.ed. Campinas-SP: Pontes, 1993.

MAINGUENEAU, Dominique. Os termos-chave da Análise do Discurso. Lisboa-Portugal: Gradiva, 1997. 
MAZIÈRE, Francine. A análise do discurso: história e práticas. São Paulo: Parábola, 2007.

MICHEL Pêcheux (1938-1983): perfil biográfico. Infoamérica, [2006]. Disponível em: <http://62.97.114.150/ fstraducirpagina.aspx?slyidioma=espbra\&url=http:// www.infoamerica.org/teoria/ting1.htm>. Acesso em: 13 jul. 2006.

MOORE, Michael. Self-directed learning and distance education. Journal of Distance Education, Otawa-Canadá, v.1, n.1, 1986. Disponível em: <http://cade.athabascau. ca/vol1.1/moore.html>. Acesso em: 23 nov. 2004.

MOORE, Michael. Teoria da distância transacional. Revista Brasileira de Aprendizagem Aberta e a Distância, v.1, n.1, jul. 2002. Disponível em: <http://www.abed.org.br/publique $/$ cgi $/$ cgilua.exe/ sys/start.htm?infoid=23\&sid=69\&UserActiveTemplate=1por>. Acesso em: 15 nov. 2004.

MOORE, Michael; KEARSLEY, Greg. Educação a distância: uma visão integrada. São Paulo: Thomson, 2007.

MORETTIN, Eduardo Victorio. Cinema educativo: uma abordagem histórica. Comunicação \& Educação, São Paulo, n.4, p.13-19, set./dez. 1995.

MOTA, Ronaldo; CHAVES FILHO, Hélio; CASSIANO, Webster Spiguel. Universidade Aberta do Brasil: democratização do acesso à educação superior pela rede pública de educação a distância. In: BRASIL. Ministério da Educação. Secretaria de Educação a Distância. Desafios da educação a distância na formação de professores. Brasília: SEED/ MEC, 2006. p.13-26. 
MUNDIM, Kleber Carlos. Ensino a distância no Brasil: problemas e desafios. In: BRASIL. Ministério da Educação. Secretaria de Educação a Distância. Desafios da educação a distância na formação de professores. Brasília: SEED/ MEC, 2006. p.119-126.

NEDER, Maria Lucia Cavalli. Educação a distância e sua contribuição na mudança de paradigmas educacionais na formação de professores. In: BRASIL. Ministério da Educação. Secretaria de Educação a Distância. Desafios da educação a distância na formação de professores. Brasília: SEED/MEC, 2006. p.79-85.

NOBLE, David. De volta à ruína?: ensino a distância, lucros e mediocridade. Le Monde Diplomatique, Edição Brasileira, v.1, n.3, abr. 2000. Disponível em: <http:// www.diplo.com..br/aberto/anteriores.htm>. Acesso em: 10 mar. 2004.

NOTAS à AAD-69. In: GADET, Françoise; HAK, Tony (orgs.). Por uma análise automática do discurso: uma introdução à obra de Michel Pêcheux. Campinas-SP: Ed. Unicamp, 1990. p.153-158.

OILO, Didier. Do tradicional ao virtual: as novas tecnologias da informação. In: UNESCO; CONSELHO DE REITORES DAS UNIVERSIDADES BRASILEIRAS. Tendências da educação superior para o século XXI. Brasilia, 1999. p.473-491.

OLIVEIRA FILHO, Gesner José. Apresentação. In: GALBRAITH, John Kenneth. O Novo Estado Industrial. 2. ed. São Paulo: Nova Cultural, 1985. p.VII-XXV. 
ONLINE EDUCA MADRID 2006, 6, Madrid-Espanha. Informe de conclusiones. Madrid-Espanha: ICWE, 2006.

ORLANDI, Eni Puccinelli. A Análise de Discurso em suas diferentes tradições intelectuais: o Brasil. In: SEMINÁRIO DE ESTUDOS EM ANÁLISE DE DISCURSO, 1., 2003, Porto Alegre. Textos dos conferencistas. Porto Alegre: Instituto de Letras/UFRGS, 2003. Disponível em: <spider.ufrgs.br/discurso/evento/conf_04/eniorlandi.pdf $>$. Acesso em: 22 jan. 2008.

ORLANDI, Eni Puccinelli. A incompletude do sujeito: e quando o outro somos nós? In: LANE, Silvia T. Maurer (Apres.). Sujeito e texto. São Paulo: Educ, 1988. p.9-16.

ORLANDI, Eni Puccinelli. A linguagem e seu funcionamento: as formas do discurso. 4. ed. Campinas, SP: Pontes, 1996a.

ORLANDI, Eni Puccinelli. Análise de discurso: princípios e procedimentos. 4.ed. Campinas-SP: 2002.

ORLANDI, Eni Puccinelli. As formas do silêncio: no movimento dos sentidos. 4. ed. Campinas, SP: Ed. Unicamp, 1997.

ORLANDI, Eni Puccinelli. Discurso e leitura. Campinas-SP: Ed. Unicamp, 1993a.

ORLANDI, Eni Puccinelli. Interpretação: autoria, leitura e efeitos do trabalho simbólico. Petrópolis-RJ: Vozes, 1996 b.

ORLANDI, Eni Puccinelli. Prefácio. In: (Org.). Discurso fundador: a formação do país e a construção da identidade nacional. Campinas-SP: Pontes, 1993b. p.7-9. 
ORLANDI, Eni Puccinelli. Quem foi Michel Pêcheux. Laboratório de Estudos Urbanos, Campinas-SP, 2005. Disponível em: <http://www.labeurb.unicamp.br/ Quem_foi_Michel_P\%C3\%AAcheux.htm>. Acesso em: 5 jan. 2008.

ORLANDI, Eni Puccinelli. Terra à vista: discurso do confronto: velho e novo mundo. São Paulo: Cortez, 1990.

ORLANDI, Eni Puccinelli; GUIMARÃES, Eduardo. Unidade e dispersão: uma questão do texto e do sujeito. In: LANE, Silvia T. Maurer (Apres.). Sujeito e texto. São Paulo: Educ, 1988. p.17-35.

ORLANDI, Eni Puccinelli; GUIMARÃES, Eduardo; TARALLO, Fernando. Vozes e contrastes: discurso na cidade e no campo. São Paulo: Cortez, 1989.

PAIVA, Vanilda. Sobre o conceito de "capital humano". Cadernos de Pesquisa, São Paulo, n.113, p.185-191, jul. 2001. Disponível em: <http://www.scielo.br/pdf/cp/ n113/a10n113.pdf>. Acesso em: 2 jun. 2008.

PAULSEN, Morten Flate. The hexagon of cooperative freedom: a distance education theory attuned to computer conferencing. Deosnews, Norway, v.3, n.2, 1993. Disponível em: <http://www.nettskolen.com/pub/artikkel.xsql?artid=125>. Acesso em: 23 nov. 2004.

PÊCHEUX, Michel et al. Apresentação da Análise Automática do Discurso (1982). In: GADET, Françoise; HAK, Tony (orgs.). Por uma análise automática do discurso: uma introdução à obra de Michel Pêcheux. Campinas-SP: Ed. UNICAMP, 1990. p.253-282. 
PÊCHEUX, Michel. A análise de discurso: três épocas (1983). Por uma análise automática do discurso: uma introdução à obra de Michel Pêcheux. Campinas-SP: Ed. UNICAMP, 1990a. p.311-319.

PÊCHEUX, Michel. Análise Automática do Discurso (AAD-69). In: GADET, Françoise; HAK, Tony (orgs.). Por uma análise automática do discurso: uma introdução à obra de Michel Pêcheux. Campinas-SP: Ed. UNICAMP, 1990b. p.61-162.

PÊCHEUX, Michel. Ler o arquivo hoje. In: ORLANDI, Eni Puccinelli (Org.). Gestos de leitura: da história no discurso. 2.ed. Campinas-SP: Ed. Unicamp, 1997. p.55-66.

PÊCHEUX, Michel. O discurso: estrutura ou acontecimento. Campinas-SP: Pontes, 1990c.

PÊCHEUX, Michel. Semântica e discurso: uma crítica à afirmação do óbvio. Campinas-SP: Ed. Unicamp, 1988.

PÊCHEUX, Michel; FUCHS, Catherine. A propósito da Análise Automática do Discurso: atualização e perspectivas (1975). In: GADET, Françoise; HAK, Tony (orgs.). Por uma análise automática do discurso: uma introdução à obra de Michel Pêcheux. Campinas-SP: Ed. UNICAMP, 1990. p.163-252.

PETERS, Otto. A educação a distância em transição: tendências e desafios. São Leopoldo-RS: Ed. Unisinos, 2003a.

PETERS, Otto. A pedagogical model for virtual learning space. Articles on Flexible Earning \& Distance Education. West Germany: FernUniversität Hagen, [entre 
2000 e 2004]. The papers were produced for Conferences on Open and Distance Learning [www.fju.dk].

PETERS, Otto. Didática do ensino a distância: experiências e estágio da discussão numa visão internacional. São Leopoldo-RS: Ed. Unisinos, 2003b.

PETERS, Otto. Distance education and industrial production: a comparative interpretation in outline. 1967. Disponível em: <http://www.umuc.edu/ide/seminar/ peters.html>. Acesso em: 24 nov. 2004.

PETERS, Otto. Duas mudanças estruturais na educação a distância: industrialização e digitalização. São Leopoldo-RS, 2001. Disponível em: <http://gemini. ricesu.com.br/colabora/n2/destaque/destaque8.htm>. Acesso em: 28 mar. 2005.

PETERS, Otto. New learning spaces. [199-] Disponível em: <http://www.fernuni-hagen.de/>. Acesso em: 24 nov. 2004.

PETERS, Otto. The iceberg has not yet melted: further reflections on the concept of industrialization and distance teaching (1989). In: KEEGAN, Desmond (ed.). Otto Peters on distance education: the industrialization of teaching and learning. London/New York: Routledge Studies in Distance Education, 1994. p.195-209. Disponível em: <http://www.fernuni-hagen.de/>. Acesso em: 24 nov. 2004.

PFROMM NETTO, Samuel. Tecnologia da educação e comunicação de massa. São Paulo: Pioneira, 1976. 
PIMENTEL, A. Fonseca. A educação e o treinamento por correspondência: histórico e potencialidades. Rio de Janeiro: DASP/Serviço de Documentação, 1955.

PINTO, Luiz. Apresentação. In: PIMENTEL, A. Fonseca. A educação e o treinamento por correspondência: histórico e potencialidades. Rio de Janeiro: DASP/Serviço de Documentação, 1955. p.3-4.

PIOVEZANI FILHO, Carlos. Análise do discurso político: novos objetos, novas perspectivas. In: NAVARRO, Pedro (Org.). Estudos do texto e do discurso: mapeando conceitos e métodos. São Carlos-SP: Claraluz, 2006. p.243-257.

PORTAL EDUCAÇÃO. Portal Educação cresce 550\% em 2007 e acompanha evolução do ensino a distância no Brasil. Linhas \& Laudas Comunicação, Rio de Janeiro, 4 jun. 2008. Disponível em: <http://www.linhaselaudas. com.br/site/releases_detalhes.php?intId=357>. Acesso em: 5 jun. 2008.

PRETI, Oreste. Educação a distância e globalização: desafios e tendências. Revista Brasileira de Estudos Pedagógicos, Brasília, v.79, n.191, p.19-30, jan./abr.1998.

REKKEDAL, Torstein. Research in distance education: past, present and future. Norway: NKI, 1994. Disponível em: <http://www.nettskolen.com/pub/artikkel.xsql?artid=139>. Acesso em: 23 nov. 2004.

REVEL, Judith. Michel Foucault: conceitos essenciais. São Carlos-SP: Claraluz, 2005.

ROMÃO, Lucília Maria Sousa; ROMÃO, Arquilau Moreira. O discurso sobre a democracia brasileira ao 
longo dos últimos vinte anos. Achegas.net, Rio de Janeiro, n. 22, mar./abr. 2005. Disponível em: <http://www.achegas.net/numero/vinteedois/lucilia_e_arquilau_22.htm>. Acesso em: 1 mar. 2008.

ROUANET, Sergio Paulo; MERQUIOR, José Guilherme. Entrevista com Michel Foucault. In: FOUCAULT, Michel et al. $\mathrm{O}$ homem e o discurso: a arqueologia de Michel Foucault. Rio de Janeiro: Tempo Brasileiro, 1971. p.17-42.

RUMBLE, Greville. Animadversions upon the concept of distance education as a discipline. Journal of Distance Education, Otawa-Canadá, v.3, n.1, 1988. Disponível em: $<$ http://www.cade-aced.ca/en_pub.php>. Acesso em: 24 nov. 2004.

SANTOS, Andreia Inamorato dos. A Universidade Aberta Britânica: aberta às pessoas, lugares, métodos e idéias. In: BRASIL. Ministério da Educação. Secretaria de Educação a Distância. Desafios da educação a distância na formação de professores. Brasília: SEED/MEC, 2006. p.211-221.

SARGENTINI, Vanice Maria Oliveira. Arquivo e acontecimento: a construção do corpus discursivo em Análise do Discurso. In: NAVARRO, Pedro (Org.). Estudos do texto e do discurso: mapeando conceitos e métodos. São Carlos-SP: Claraluz, 2006. p. 35-44.

SAUL, Renato P. As raízes renegadas da teoria do capital humano. Sociologias, Porto Alegre, v.6, n.12, p. 230-273, jul./dez. 2004. Disponível em: <http://www.scielo.br/ pdf/soc/n12/22262.pdf>. Acesso em: 20 maio 2008. 
SCHLUNZEN, Elisa Tomoe Moriya; SCHLUNZEN JUNIOR, Klaus; TERÇARIOL; Adriana Aparecida de Lima. Fundamentos pedagógicos para a formação em serviço nos cursos de graduação do programa Pro-licenciatura. In: BRASIL. Ministério da Educação. Secretaria de Educação a Distância. Desafios da educação a distância na formação de professores. Brasília: SEED/MEC, 2006. p.93-117.

SIMONSON, Michael et al. Teaching and learning at a distance: foundations of distance education. 2.ed. Old Tappan-Estados Unidos: Prentice Hall, 2003.

SIMONSON, Michael. Equivalency theory and distance education. In: Readings in distance education. Fischler Graduate School of Education and Human Services Nova Southeastern University, [entre 2000 e 2004].

SOUZA, Paulo Renato. Apresentação. In: BRASIL. Ministério da Educação. Secretaria de Educação a Distância. Política e resultados 1995-2002: tecnologias na educação básica. Brasília, 2002. p.4.

SOUZA, Paulo Renato. Dois anos da TV Escola. In: BRASIL. Ministério da Educação. Secretaria de Educação a Distância. 2 anos da TV Escola: Seminário Internacional: 1998. Brasília, 1999. p.17-20.

SUA EXCELÊNCIA, o treinamento. In: ABRAEAD 2007: anuário brasileiro estatístico de educação aberta e a distância. São Paulo: Instituto Monitor/ABED/SEED/MEC, 2007. p.137-141.

SUPLICY, Eduardo Matarazzo. Sobre o legado de John Kenneth Galbraith. Revista de Economia 
Política, São Paulo, v.26, n.4, p.619-626, out./dez. 2006. Disponível em: <http://www.scielo.br/scielo.php?pi$\mathrm{d}=$ S0101-31572006000400009\&script $=$ sci_arttext $>$. Acesso em: 10 abr. 2008.

THE EDITORS. Series Editors' Foreword. In: PETERS, Otto. Distance education in transition: new trends and challenges. 3.ed. Germany: Bibliotheks- und Informationssystem der Universität Oldenburg, 2003.

TIFFIN, John; RAJASINGHAM, Lalita. A universidade virtual e global. Porto alegre: Artmed, 2007.

UNESCO. Aprendizagem aberta e a distância: perspectivas e considerações sobre políticas educacionais. In: UNESCO; CONSELHO DE REITORES DAS UNIVERSIDADES BRASILEIRAS. Tendências da educação superior para o século XXI. Brasília, 1999. p.657-720.

UNIVERSIDADE DE BRASÍLIA. Biblioteca Central. Pesquisa geral: Antonio Fonseca Pimentel. Brasília, 2008. Disponível em: <http://consulta.bce.unb.br/pergamum/biblioteca/index.php>. Acesso em: 20 abr. 2008.

VERTECCHI, Benedetto. Elemente einer theorie des fernunterrichts - Inhalt. ZIFF-Papiere, Hagen-Germany, n.109, 1998. Disponível em: <http:/ / www.fernuni-hagen. de/ZIFF/ziff109/109-contents.htm>. Acesso em: 06 dez. 2004.

VITALE, Luis. Modos de producción y formaciones sociales en America Latina. Luis Vitale: obras escogidas, Santiago-Chile, [198-]. Disponível em: <http://mazinger. 
sisib.uchile.cl/repositorio/lb/filosofia_y_humanidades/ vitale/obras/obras.htm>. Acesso em: 4 dez. 2007.

WEBER, Max. A ciência como vocação. In: Ensaios de sociologia. Rio de Janeiro: Zahar, 1963a. p.154-183.

WEBER, Max. Burocracia. In: . Ensaios de sociologia. Rio de Janeiro: Zahar, 1963b. p.229-282.

WEBER, Max. Economia e sociedade: fundamentos da sociologia compreensiva. 3.ed. Brasília: Ed. UnB, 1994. v.1.

ZEDONG, Mao. Sobre a prática: sobre a relaçom entre o conhecimento e a prática, entre o saber e o fazer. Arquivo Marxista na Internet. 1937. Disponível em: <http:// www.marxists.org/portugues/mao/1937/07/pratica-ga.htm >. Acesso em: 15 set. 2007.

ZOPPI-FONTANA, Mónica Graciela. Cidadãos modernos: discurso e representação política. Campinas-SP: Ed. Unicamp, 1997. 


\section{Sobre o livro}

\section{Projeto Gráfico e Editoração Leonardo Araujo}

Capa Erick Ferreira Cabral

Formato $15 \times 21 \mathrm{~cm}$

Mancha Gráfica $\quad 10,3 \times 16,5 \mathrm{~cm}$

Tipologias utilizadas Book Antiqua 11,5 
